
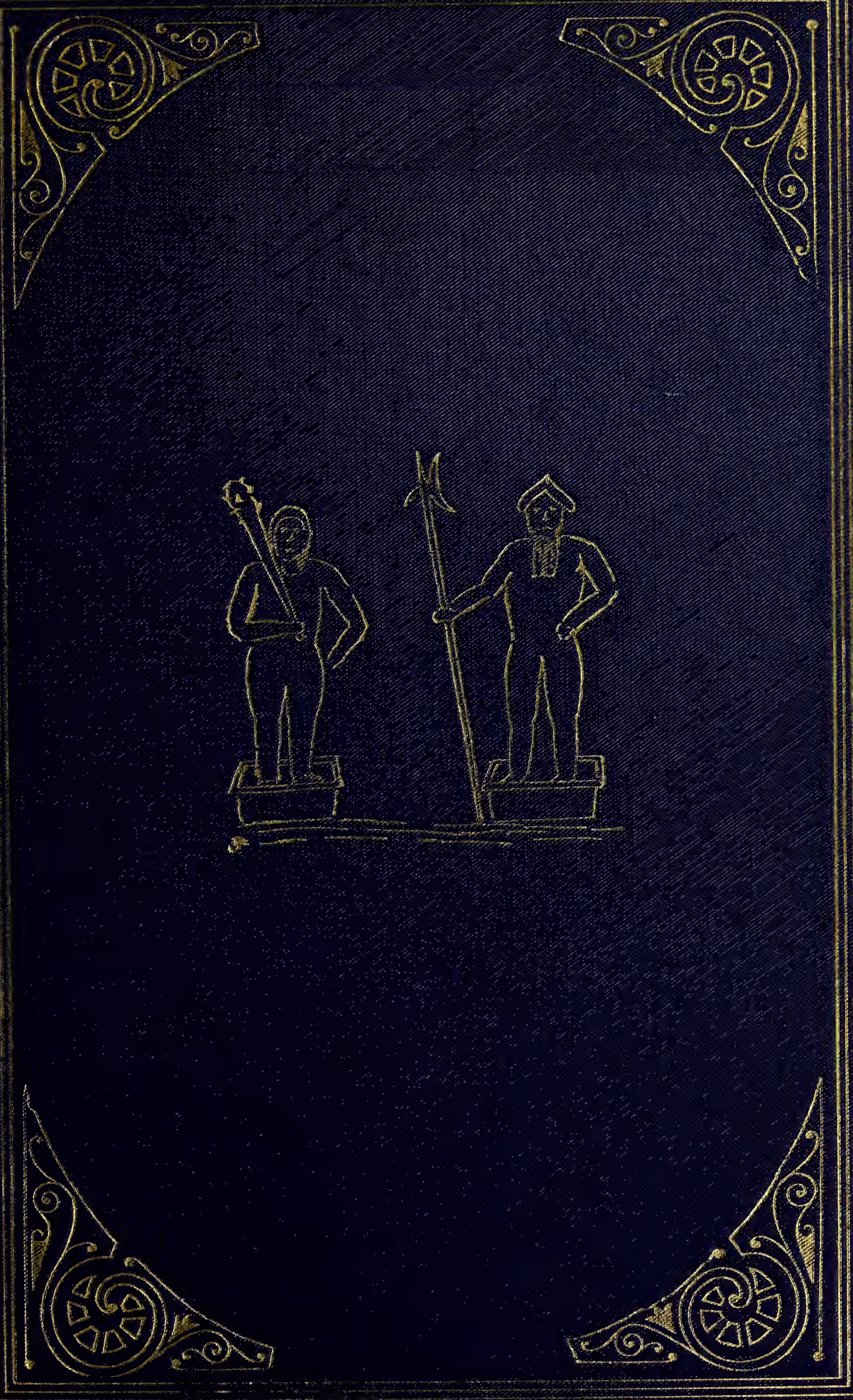



\section{OXFORD GARDENS}



Digitized by the Internet Archive in 2014 


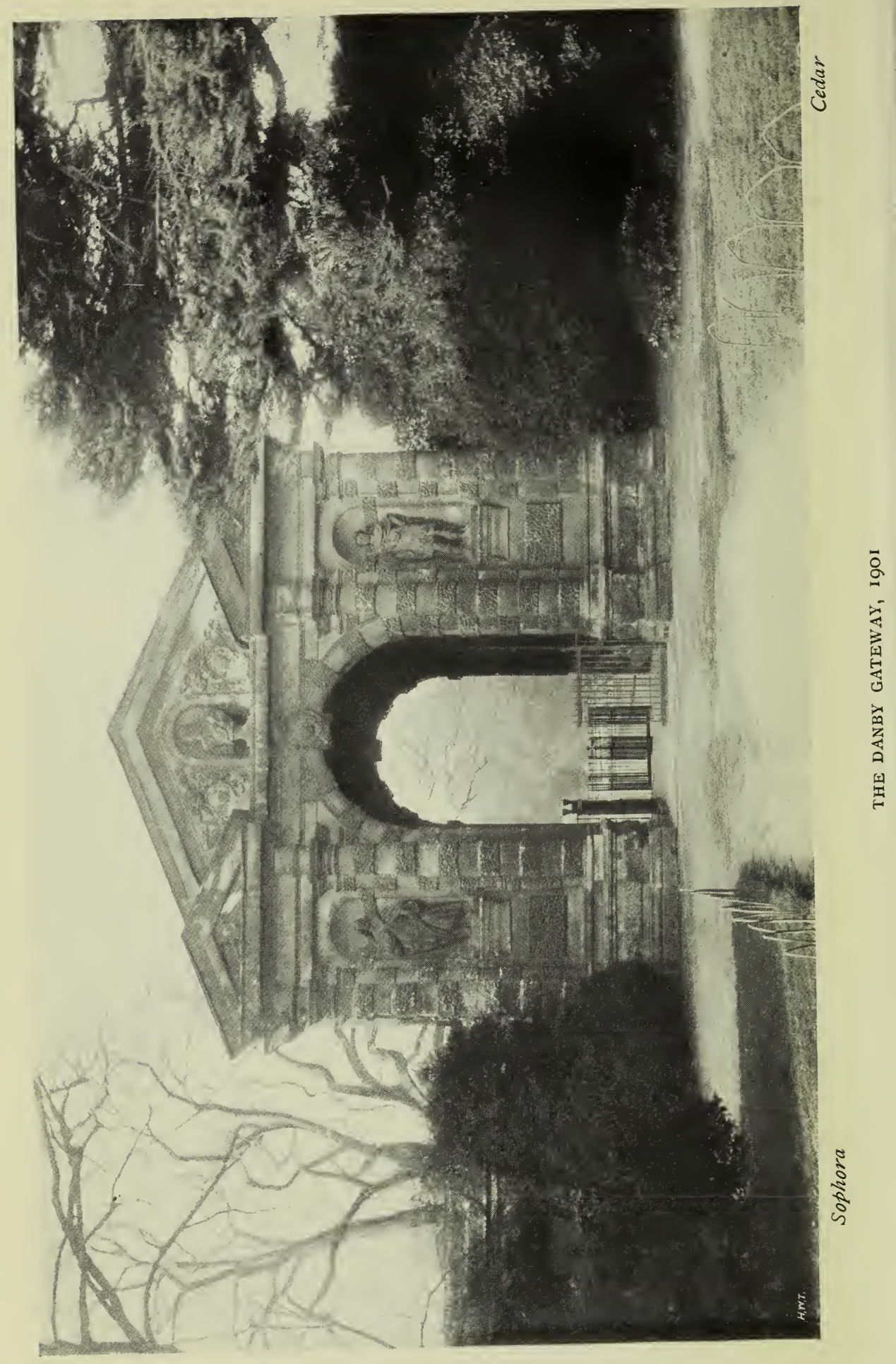




\section{OXFORD GARDENS}

BASED UPON

DAUBENY'S POPULAR GUIDE TO THE PHYSICK GARDEN OF OXFORD :

WITH NOTES ON THE GARDENS OF THE COLLEGES AND ON THE UNIVERSITY PARK

BY

\section{R. T. GÜNTHER, M.A.}

FELLOW OF MAGDALEN COLLEGE, OXFORD

"Consider the lilies how they grow"

OXFORD: PARKER \& SON

LONDON : SimpKin, Marshall \& Co. 
'Tis State employment: You a book compile That musters all the Natives of this Isle.

And forein herbs surpriz'd in English ground Are taken Prisoners and together Bound.

The Plants so neatly are describ'd, th' are known Better by these your leaves, than by their own. If men would view their roots too, here they'l see Them in their unstrain'd Etymologie.

Here Plants collected are, and publish'd; thus You gather Plants, not for your selves but us. We'd crown your worth with Garlands but the flowrs That we combine, must be your own, not ours. When Garden Plants shall dye, yours most shall thrive And shall preserve, themselves, and you alive.

William Hawkins to Dr. Stephens and Mr. Browne on their Catalogue.

\section{8}
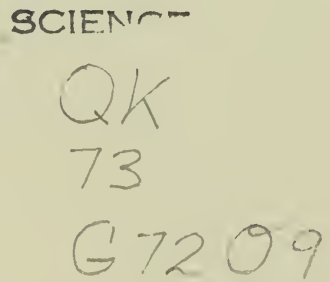
DEDICA'TED

TO THE MEMORY

OF A NAMESAKE OF

A MEMBER OF MY OWN COLLEGE

\section{RALPH AUSTEN}

who wrote a Treatise on Fruit Trees in 1653, which many refused to buy, believing it similar to his other book on the Spirituall Use of an Orchard, described as "all divinity, and nothing therein of the practice part of Gardening." 


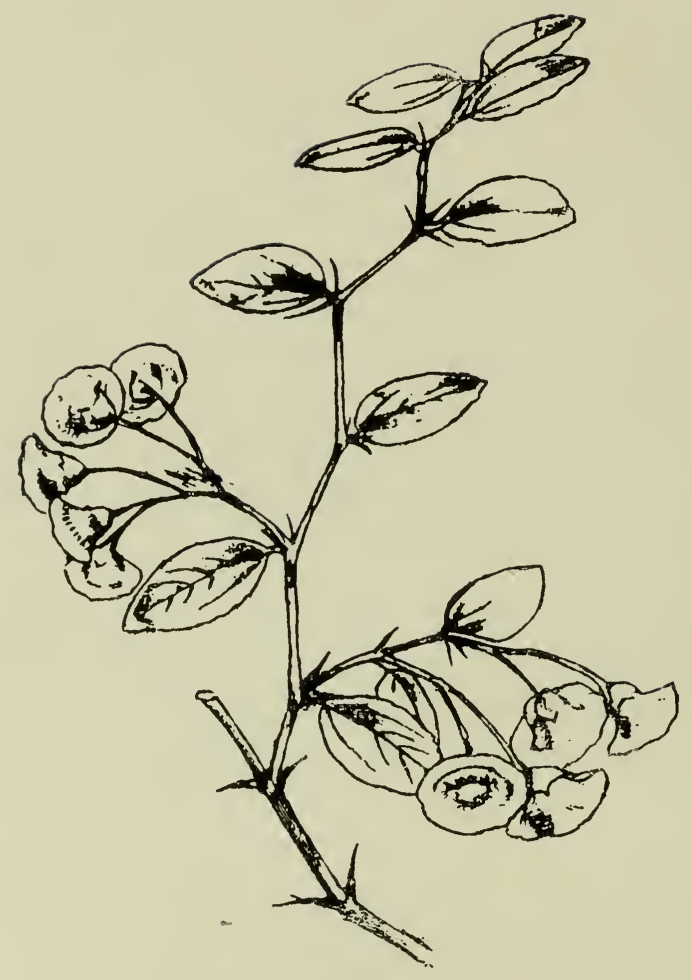

CHRIST'S THORN

Paliurus aculeatus 


\section{PREFACE}

The reissue of this account of the Oxford Botanic Garden in a revised and enlarged form is due to the fact that neither the guides written by Dr. Daubeny nor the Garden itself are as well known in Oxford as they ought to be.

To the description of the principal Garden we have added shorter accounts of the most noteworthy plants in the Gardens of the Colleges and of the University Park.

The first edition of Dr. Daubeny's Guide was printed in Oxford and sold in Oxford about sixty years ago, and yet the most diligent search in the library of his College, in the library of the Botanic Garden, in the Bodleian Library, and in other public libraries in Oxford has failed to bring any copy to light.

Similarly, of the second edition not a single complete copy is forthcoming here. Neither is any edition easily found in the second-hand market; no bookseller has been able to procure me a copy; one, indeed, doubted the book's existence.

Though to some extent comprehensible that a sixpenny guidebook may become scarce, that the existence of the Garden as a separate institution should have been forgotten for a long time in the University, even in semi-official publications, is much more unaccountable.

It was evidently unknown as a University institution to the compilers of the University Calendar during the greater 
part of the nineteenth century. Only within the last few years has it been included in the list of University institutions in that publication. And, strangely enough, this recognition has coincided with the residence of the Secretary to the Delegates of the University Press in a house overlooking it. The Garden has never since been absent from the list of institutions in the Calendar; but in the Historical Registers of the University of Oxford up to and including the year I900 it has no place. Now, however, when recognised, its description is misleading. In the most recent and revised edition of the "Student's Handbook" it is mentioned as "the first piece of public ground set apart in this country for the scientific study of plants." Now, the ground is not what is commonly understood as public property, and never was; it is part of the corporate estates of Magdalen College, leased to the University for the benefit of medical, horticultural, and botanical science.

In the face of omission from publications that are so often referred to as authoritative and official, it is hardly surprising that we should not have found adequate mention of the Garden elsewhere. A few instances : The reader of a recent address on the growth and development of the Oxford Medical School made no mention of her ancient Medical Garden, founded for the cultivation of "phisical simples." Again, on the occasion of a visit of the Managers of the Royal Institution, the oldest Botanic Garden in England was the only University institution of importance omitted from the list of objects worthy of their notice. In the best of small guides to Oxford and its colleges, there is no allusion to the Garden, although there is a whole chapter devoted to the University collections. Professor Vines has pointed out that the very date of the foundation of the Garden is in most cases inaccurately stated, being wrong by a decade. And lastly, it happened a few days ago that we came across a new book with the alluring title, 
"Oxford, its Buildings and Gardens," which justified the lively hope (the price of the book being one guinea) that at least one chapter might be given to a description of the principal Garden; but in the time at our disposal, we could find no allusion to it.

It would appear, then, that the last word upon the Garden has not yet been written; we would welcome a comprehensive account of its various successes and failures, and of the varied activities of those who have been fortunate enough to have charge; but such an account would require not only the services of an historian, but also the collaboration of those skilled in the technicalities of the produce, whether horticultural, forestal, pharmacological, or botanical. Nor would we wish it to be merely a catalogue, but a work that a garden-loving public might read with pleasure.

The present little book does not claim to meet this requirement; it has been put together, a labour of love, to recall to this and future generations some forgotten details of the work of a pioneer of natural science in Oxford -the many-sided Dr. Daubeny; to indicate the noble trees which have sprung from seed of his sowing. We leave the timber rough-hewn; the carving will be for the more skilful chisels of those that come after. We hope that they too may share the

backward thoughts of sympathy

With him who writes, for memory's sake.

We wish that we might possess the knowledge necessary to do more justice to the recent work of many of the departments, but the naval rule of not talking to the man at the wheel has applied here; we could not venture to trouble busy people too much.

Our friend the Professor of Botany, to whom, however, we did apply, has helped us negatively in a considerable way, for he ended our quest for records of the past at the outset 
by the statement that there are no old official records in his possession. Indeed, when we consider the history of the management of the Garden, nothing is more natural than that there should not have been. And so the chronicler is dependent upon external sources of information-sometimes of a very scrappy nature. It is stated that now a private register is being kept of the date of accession of every single plant in the collection, and of every single root, bulb, or packet of seeds that is sent away, with the name of the recipient. It would obviously be unfair to the compilers to have creamed so stupendous a record, even had it been accessible, but occasional consultations might have saved many errors.

The chief sources of information other than those to which acknowledgment is made, have been the Garden labels and the Oxford University Gazette. I have required, and received, assistance in all the departments touched upon in this book. To past and present officers of the Royal Gardens at my old home at Kew I owe much: to the works of Sir Joseph Hooker, for whose recent loss to the world of Science, botanists are still mourning, and to the late Curator of the Gardens, Mr. George Nicholson, I am under especial obligations. At Oxford, Mr. Baker and other members of the staff have answered occasional questions concerning the Garden, its books, and its plants. Mr. G. C. Druce and Mr. Warde Fowler, to whom all must turn who would discourse on Oxford botany or Oxford birds, have supplied notes on that flora and fauna of which they are the greatest living exponents. Messrs. Hiley and Hamm have supplied lists of insects, and the Rev. Hilderic Friend a valuable list of earthworms, including two new forms not recorded elsewhere. The photographs, specially chosen to illustrate the appearance of the Garden in Dr. Daubeny's day, were, unless otherwise stated, taken by Mr. Taunt, who has generally been able to ascertain the exact date of each. The original woodcuts used by Dr. Daubeny, 
by the courtesy of Mr. James Parker, and to our especial pleasure, again do duty, after half a century. Two illustrations from "Riviera Notes," and two others from "Summer Days on the Thames," have been lent by Mr. Quaritch and by Messrs. Seeley, Service \& Co., respectively. To both I return thanks.

Last but not least, I must thank my numerous friends in other Colleges who have been so kind as to look through the paragraphs on their own gardens, and thus greatly to diminish the number of inaccuracies in my compilation. To Professor Somerville the reader is indebted for one of the first, if not actually the first, published accounts of the trees in the University Park.

\section{February 1912.}

R. T. G.

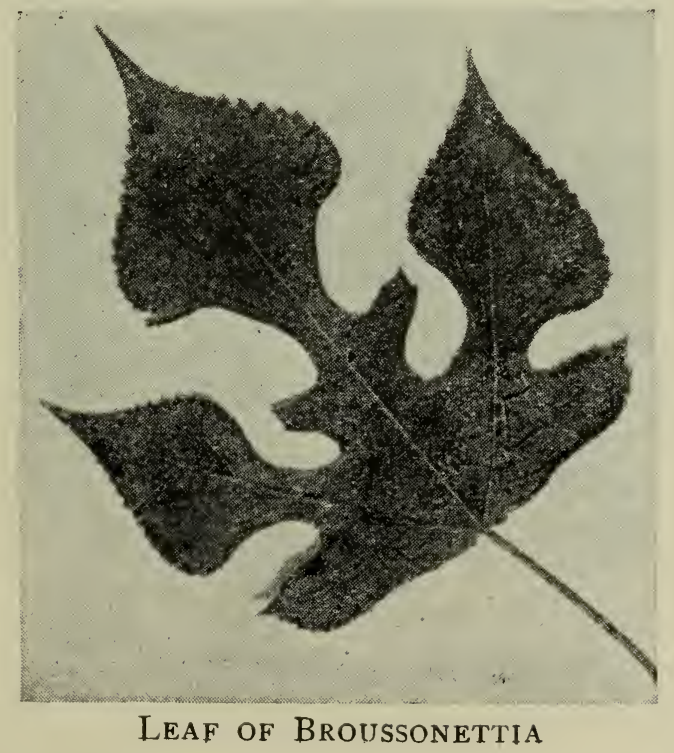




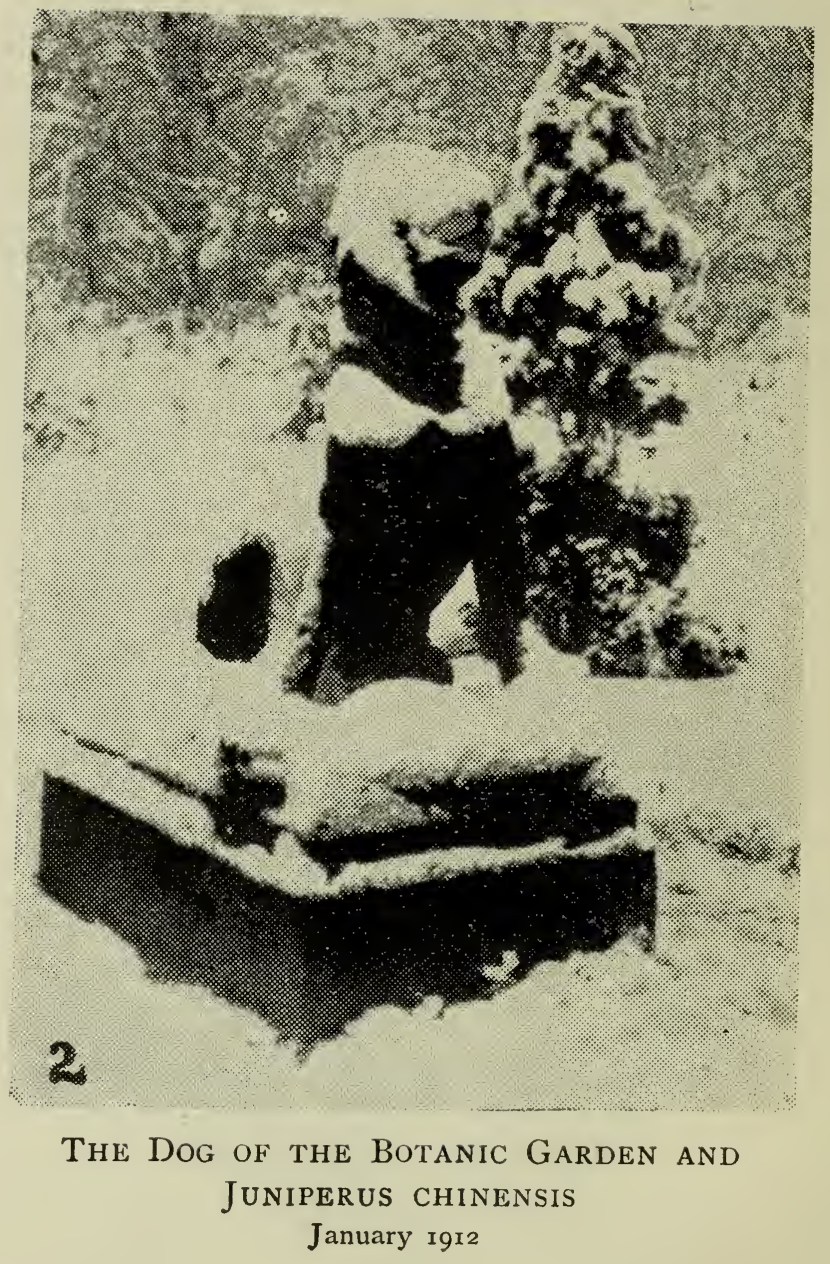




\section{CONTENTS}

\section{THE BOTANIC GARDEN}

PAGE

HISTORICAL INTRODUCTION •

HaRdy Plants . . . . . . . . 33

Trees, Shrubs, and Wall Plants . . . . 35

Tree Plan . . . . . . . . . 36

Hardy Herbaceous Plants . . . . . 53

Plan of Beds. . . . . . . . . . 55

Hardy Aguatic Plants . . . . . . 90

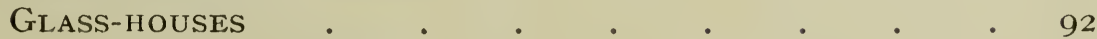

3. Green-house . . . . . . . . 94

4. Conservatory . . . . . . . . . 95

5. Fern House . . . . . . . . . 99

6. Water-lily House . . . . . . 102

7. Small Stove-house . . . . . . 107

8. Palm House . . . . . . . II3

9. Orchid House . . . . . . I2O

io. Succulent House . . . . . . . 123

i i. Propagating-House. • . . . . $\quad$ i 29

I2. Green-house . . . . . . . I3O

Weeds and Wild Plants . . . . . . 132

FAunistic Notes . . . . . . . . . I 35

Climate and Soll $\quad . \quad$. $\quad . \quad . \quad . \quad . \quad$ I 43

Wall Plants, Climbers, etc. . . . . . I44

Herbarium . . . . . . . . 148

Botanical Museum . . . . . . . . i5I

LIBRARY . $\quad . \quad$. $\quad . \quad$. . $\quad$ I 52

Lecture Rooms and Laboratories . . . . I55

Professor's HOUSE . . . . . . . I62

Experimental Garden . . . . . • $\mathrm{I}_{5}$

Government $\quad$ • . . . . . . I70 
Finance

VISITORS

Books AND PRINTs

APPENDICES

A. Baskerville's Account . . . . . I88

B. List of Succulents sent to KeW . • . I93

C. “Nemo's” Leaflet . . . . . . . . 194

D. Forest Gardens . . . . . . . . 197

E. College Gardens . . . . . . 201

Christ $\mathrm{CHURCH}$. $\quad$. $\quad$. $\quad$. 203

Pembroke

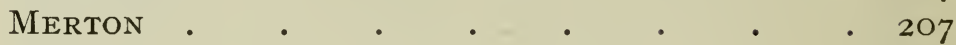

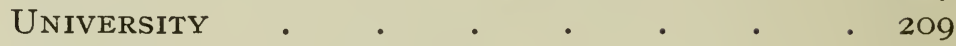

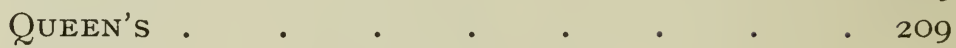

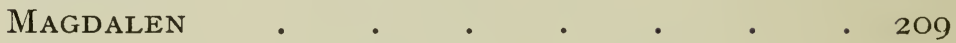

NEW $\quad . \quad . \quad . \quad . \quad . \quad . \quad .222$

All Souls . $\quad . \quad$. $\quad . \quad$. $\quad .225$

BRASENOSE . . . . . . . . 225

EXETER . . . . . . . . . 225

LINCOLN .

TRINITY $. \quad . \quad . \quad . \quad . \quad . \quad . \quad .228$

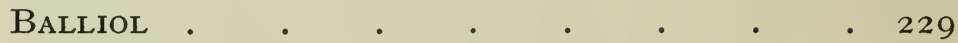

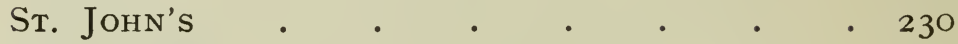

WORCESTER $\cdot \quad \cdot \quad \cdot \quad \cdot \quad \cdot \quad \cdot \quad \cdot 232$

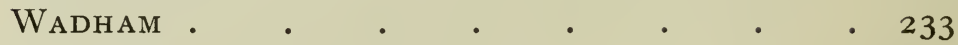

F. The Parks . . . . . . . . . . 237

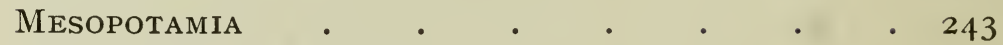

G. Radcliffe Observatory . . . . . 245

High Street . . . . . . . . 246

HEAdington Hill . . . . . . $\quad .248$

OXford StREets . . . . . . . 250

H. Wild Gardens . . . . . . . $25 \mathrm{I}$

I. Gardens of Winds and Birds in Mesopotamia . 253 INDEX TO THE Botanic GaRden . . . . . 26I Index to the College Gardens and the Parks • • 277 


\section{LIST OF ILLUSTRATIONS}

THE DANBY GATEWAY, I9OI

Frontispiece

PAGE

CHRIST'S THORN

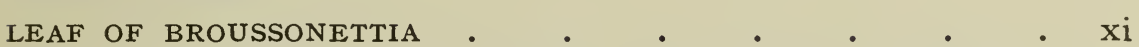

THE DOG OF THE BOTANIC GARDEN AND JUNIPERUS CHINENSIS Xii

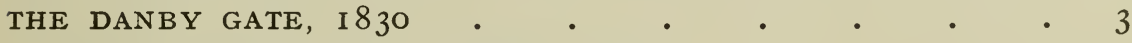

LOGGAN'S PLAN OF THE GARDEN, I675 • • • • 7

THE BOTANIC GARDEN, CIRC. I733, AFTER WILLIAMS • • I 5

THE PROFESSOR'S HOUSE, I835 • • • • • . . I6

THE DAUBENY LABORATORY AND LECTURE ROOM • . FACING 35

OXFORD BOTANIC GARDEN • . . . . . . . , 46

ECONOMIC, WATER-LILY, ORCHID, AND NO. 4 GREEN-

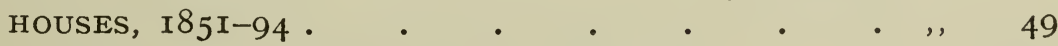

THE MUSEUM AND LECTURE ROOM, I879-I9II . . , , 64

HERACLEUM GIGANTEUM . . . . . . . , , 64

THE MIDDLE WALK, LOOKING SOUTH . • . • • " , 90

THE FOUNTAIN IN SUMMER . . . . . . . , , 9 I

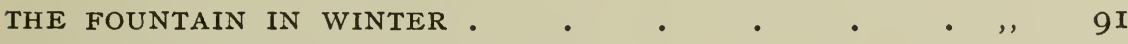

THE OXFORD HEATING APPARATUS . • . . . . 92

THE GLASS HOUSES • • • • • • . . . FACING 96

ECONOMIC, VICTORIA LILY, AND ORCHID HOUSES, I85I-94 • 98

THE WATER LILY HOUSE . . . . . . . . FACING IO2

THE PALM HOUSE • • • • . . . . , II2

THE MUSEUM AND LABORATORY . . . . . . , , I52

THE PROFESSOR'S HOUSE AND LIBRARY • • • • ", I52

THE ARCHITECTURAL CONSERVATORIES . • . . , I53

DAUBENY COTTAGE AND THE EXPERIMENTAL PLOT , , I68

CLIPPED YEWS •

THE MAGDALEN OAK, I675 . . . . . . . . 214

WITCHES' BROOM . . . . . . . . FACING $2 \mathrm{I} 4$

THE MAGDALEN COLLEGE WYCH ELM • • • • " 2 I8

THE ELMS IN MAGDALEN COLLEGE GROVE • • . , 2 I9

WORCESTER COLLEGE GARDEN . • . . . . . 236

JO. PULlEN'S TREE • • • • • • • • • • • 249

THE LAST OF THE POPLARS . . . . . . 252 
$(14)$ 


\section{THE OXFORD BOTANIC GARDEN INTRODUCTION}

Now wat there made, fast by the tower's wall, . A garden faire.-The King's Quair.

The Oxford Botanic Garden is the oldest in Great Britain.

The earliest Botanic Garden in England was that of the celebrated herbalist, John Gerarde, who published a catalogue of plants growing in the garden of his house in Holborn at the end of the sixteenth century.

The establishment of a Garden at Oxford may have been suggested by one at South Lambeth which had been recently formed for the cultivation of exotic plants by John 'Tradescant, * gardener to King Charles I., and was doubtless stimulated partly by the example of foreign towns, $\uparrow$ and partly by a lively interest in the pursuit of botanical knowledge which found expression in the periodical "herbarizings" of the "Socii itinerantes," as the members of the Society of Apothecaries were then called.

Henry Lord Danvers, Baron of Dauntsey in the county of Wilts, and Earl of Danby in Yorkshire, a gentleman commoner of the House, who, "being minded to become a benefactor to

* Rather more than a century later Tradescant's Garden had fallen into total neglect, and was quite covered with weeds, and of the exotic plants only a few survived, including two large Arbutus trees and a fine Rhamnus catharticus (William Watson, I749).

$\dagger$ The dates of the establishment of some Botanic Gardens in Europe indicate the rate and line of march of the science :

I309. Salerno. Medical Garden of Mathaeus Sylvaticus.

I333. Venice. Medical Garden.

1533. Padua. The first Botanic Garden.

I544. Pisa. Founded by Cosmo de Medici. I 577. Leyden. Montpellier, Breslau, and Heidelberg before $\mathbf{I} 600$.

1597. Paris. Established to vary the bouquets worn at Court, but 1621. Oxford. known after 1635 as the Jardin des Plantes.

1677. Chelsea. I680. Edinburgh.

I760. Kew. 
the University, determined to begin and finish a place whereby learning, especially the faculty of medicine, might be improved," bought out Humphrey Ellis, the tenant of 5 acres of meadow, for $\mathcal{E}^{250}$, and arranged that the University should lease the ground from Magdalen College for 4os. per annum.

"The opening ceremony took place at 2 p.m. on the $25^{\text {th }}$ of July, St. James's Day, in the year of our Lord, I62I, when the Vice-Chancellor and other dignitaries of the University went solemnly from St. Mary's Church to the Garden, where, being settled, Mr. Edward Dawson, a Physician of Broadgates Hall, and Dr. Clayton, the Regius Professor of Medicine, each spoke an oration. Afterward the V.C. laid the first stone, with the offering of money thereon, according to the ancient custom; then several Doctors, and both the Proctors; which being done, the Vice-Chancellor concluded with a brief Oration."

The direct lease of the ground from Magdalen College was dated July 28, and by November 6, 162 I, articles between Lord Danby as "founder of the publick Garden" and others had been drawn up and signed, and obligations had been laid upon the masons, to set up and make the Garden wall "well fair and sufficient as well as Al soules Colledge walls, Magdelen Colledge Tower, or any the fairest buildings of that kind in Oxford both for truth and beauty." *

Meanwhile the land was raised considerably to prevent the overflowing of the water, and " 4000 load of mucke \& dunge laide by $\mathrm{H}$. Windiat ye Universitie scavenger" ( 62 I-6).

Gateway and wall were not finished until 1632 and 1633 respectively: the gateway was built by Neklaus Stone from a design by Inigo Jones. The two figures of Kings Charles I. and II., which stand in niches on the right and left of the archway, were put up at a later period: it is said with the fine imposed upon Antony à Wood for a libel on the Earl of

* The document is in the custody of the Keeper of the University Archives, to whose courtesy I am indebted for inspecting it. 
Clarendon. The total cost to Lord Danby exceeded $£ 5, \infty 00$. He only had time to have the land planted with " divers simples for the advancement of the faculty of medicine "when the outbreak of the Civil Wars stopped his munificent designs for the encouragement of botanical science, and, it is said, John Tradescant from becoming our Gardener. On his death, on January 20, r644-5, it was found that he had devised to the

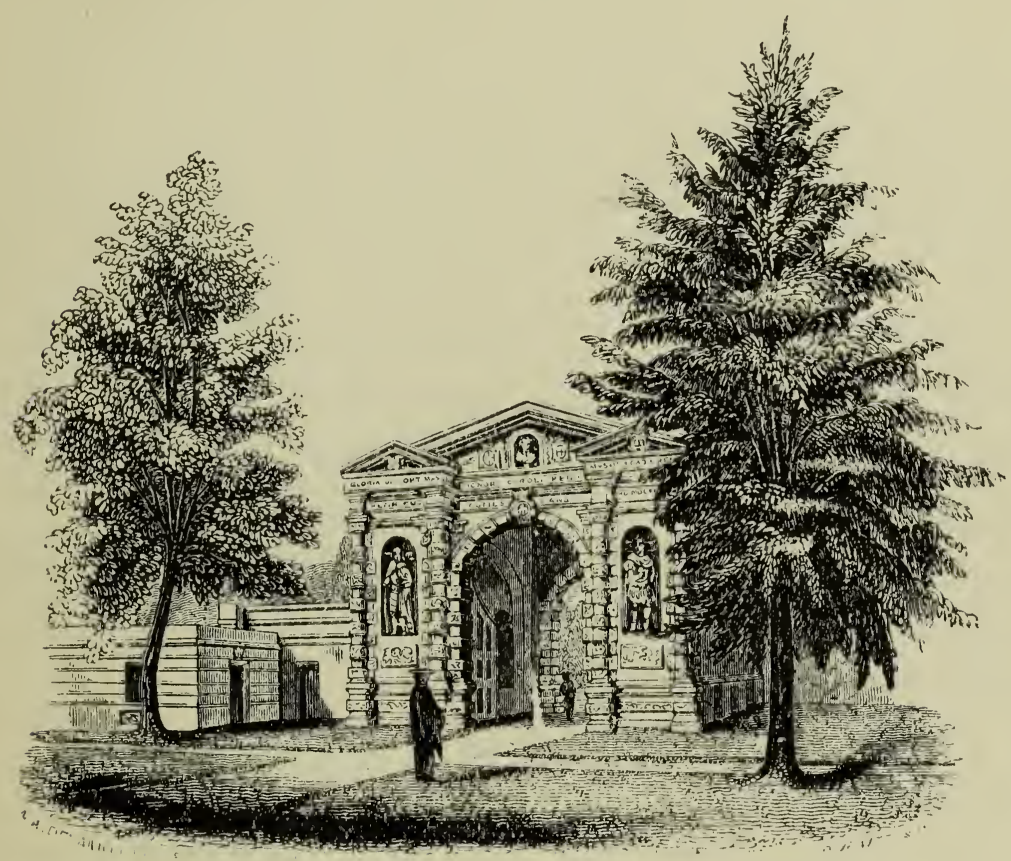

Porter's Lodge

Cedar

The Danby Gate, I830

University the rectory of Kirkdale in Yorkshire, for the use of the Garden; and his brother, Sir John Danvers, endeavoured to effect an arrangement by which the Garden should be kept in order, and the Professor and gardener receive a stipend, out of the revenues of the said estate. Owing, nevertheless, to the unsettled state of the times, and to the want of sufficient funds from the estate, which turned out less valuable than had been thought, no step was taken towards the settle- 
ment of a Professor till the year I669, when Dr. Robert Morison* made application to the University for the appointment; upon which it was agreed that an annual stipend of $£ 40$ should be allowed him on condition of his reading lectures at certain times, most convenient to himself, during the spring and autumn. Accordingly he delivered his inaugural lecture in the School of Medicine on September 2, 1670: and on the $5^{\text {th }}$ of that month removed to the Physic Garden, where he "read in the middle of it (with a table before him) on herbs and plants thrice a week" to a considerable audience. The following spring and autumn his course of lectures was repeated, and occasionally, as it would appear, afterwards, for in 1675 Evelyn attended one of them. $\mathrm{He}$ was diverted, however, from continuing them regularly by the prosecution of his great work, the "Historia Plantarum Oxoniensium," of which he first published a specimen under the title of "Plantarum Umbelliferarum Distributio nova," and afterwards a volume of the same work, entitled "Plantarum Historiae Universalis Oxoniensis pars secunda," containing a description of herbaceous plants only; the account of the trees and shrubs, which was to constitute the first part of his work, having never been printed.

* This learned botanist was a native of Aberdeen, where he received his education. Espousing the royal cause during the troubles, he received a dangerous wound in the shoulder at the battle of Brigg, near Aberdeen ; and upon his recovery took refuge in Paris, where he applied himself assiduously to the study of anatomy, botany, and zoology. In I648 he took the degree of Doctor of Physic at Angers. From his skill in botany he was appointed superintendent of the Duke of Orleans' fine garden at Blois, which he held till the death of the duke in 1660 . Being known to Charles II., he was invited to England by that monarch, and appointed king's physician and Professor of Botany, with an appointment of $£ 200$ and a house, as superintendent of the royal gardens. He died in London, Nov. 9, 1683, aged sixty-three, from a bruise on his breast by the pole of a coach as he was crossing the street between the end of St. Martin's Lane and Northumberland House.

Prof. Vines has recently delivered a lecture on Ray and Morison. 
Morison seems to have been interested in the problem of variegated plants, for a "greater Maple, miscalled the Sycamore, was found striped white in Magdalen College Grove and translated thence into the Physick-garden," where there was also a "white-striped Dulcamara from the stock at the Duke of Orleans his house at Blois which Professor Morison explained as the result of the artificial substraction of nourishment brought about by the lime and building rubbish in which the parent plant grew." *

During the period that the Professorship was held by Morison, Jacob Bobart the elder, a native of Brunswick, was Horti praefectus, gardener or supervisor. $\uparrow$ He had been appointed to the post at the age of thirty-three, in $163_{2}$, and in

* Plot's " Oxfordshire."

$\dagger$ We have several portraits of him :

I. Size $8 \frac{1}{4}$ in $\times 5^{\frac{3}{4}}$ in., D. Loggan, del., M. Burghers, sculp. Sold by M. Burghers, in I709. Beneath the head, dated I675, is inscribed:

Thou Germane Prince of plants, each yeare to thee

Thousands of subjects grant a subsidie.

A reprint by Wm. Richardson appeared July I, I800.

2. Size $6 \frac{1}{2}$ in. $\times 4$ in. A full-length portrait of Bobart standing near the Danby gateway holding a flower and the staff of Aesculapius, and accompanied by a goat, a dog, and a stork flying. Clipped plants are seen in the background. Engraved by Burghers.

3. Small whole-length portrait in the frontispiece to "Vertumnus," 8vo, Oxford, I7I3. In this he is dressed in a long vest, and is holding a plant in his hand.

In all we see the long beard which on occasion reached to the waist, and which, on "rejoicing days," he used to have tagged with silver (Granger's " Biog. Hist. Eng."). It is, moreover, related that on his walks abroad he was attended by a goat instead of a dog.

Ray, in a letter to Aubrey, noted his diligence in observing and in making a collection of insects. And names said to be in his handwriting are written on 227 folio drawings of plants in the British Museum.

He was buried in the churchyard of St. Peter's-in-the-East, and against the south wall is a small tablet:

To the Pious memory of Jacob Bobart, a native German. A man of great integrity, chosen by the founder to be keeper of the Physic Garden. He dyed Feb. 4, 1679, in the 8 ist year of his age. 
I648 he published the first Catalogue of the Plants in the Garden,* which shows him to have been truly "an excellent gardener and botanist," as Dr. Plot described him. By his diligence the valuable contents of the Garden had been so largely increased that there were sixteen hundred "stirpes," but very many were varieties-for instance, of Primulas there were "Feild Cowslips, Feild Oxelips, Double Paigles, Cowslips two in a hose, Feild Primerose, Double White Primerose, Single White Primerose, Single Purple Primerose, Single Blew Primerose, Greene Primerose, and Curld Cowslip." A second edition of the Catalogue appeared in I $_{5} 8$, and the generic name Primula was changed to Paralysis. $\uparrow$

John Evelyn tells us that the sensitive plant was shown in July, 1654, as a great wonder. "There grew canes, olivetrees, rhubarb, but no extraordinary curiosities, besides very good fruit, which when the ladys had tasted, we returned in our coach to our lodgings." And again, that in October, I664, there "were two large locust trees, and as many platani, and some rare plants under the culture of old Bobart," who in $\mathbf{1 6 6 9}$ was able to show to Ashmole "many choice plants,

By will he devised " unto my eldest son Jacob Bobert, the lease of my Greyhound Inn and meadow, holden from Magdalen College, and all my garden plants and half my books." Tilleman Bobart had the other half of the books.

See Bobart, H. Tilleman, "A Biographical Sketch of Jacol Bobart of Oxford, together with an account of his two sons Jacob and Tilleman." With a portrait reprinted from the "Journal of Horticulture," Oct. 2I, I875. Printed for private circulation only, I884.

* "Catalogus Plantarum Horti Medici Oxoniensis. Sc. LatinoAnglicus and Anglico-Latinus, Eas Alphebetico ordine accurate Exhibens." I $2 \mathrm{mo}, \mathrm{I} 648$.

$\dagger$ The second edition of the "Catalogus Horti Botanici Oxoniensis" was much improved by the joint labours of Dr. Philip Stephens, Fellow of New College, and sometime Principal of Magdalen Hall ; William Browne, Fellow of Magdalen College; Jacob Bobart, the first Keeper of the Garden; and his son Jacob Bobart, the Professor. 
South Elevation of the Conservatory

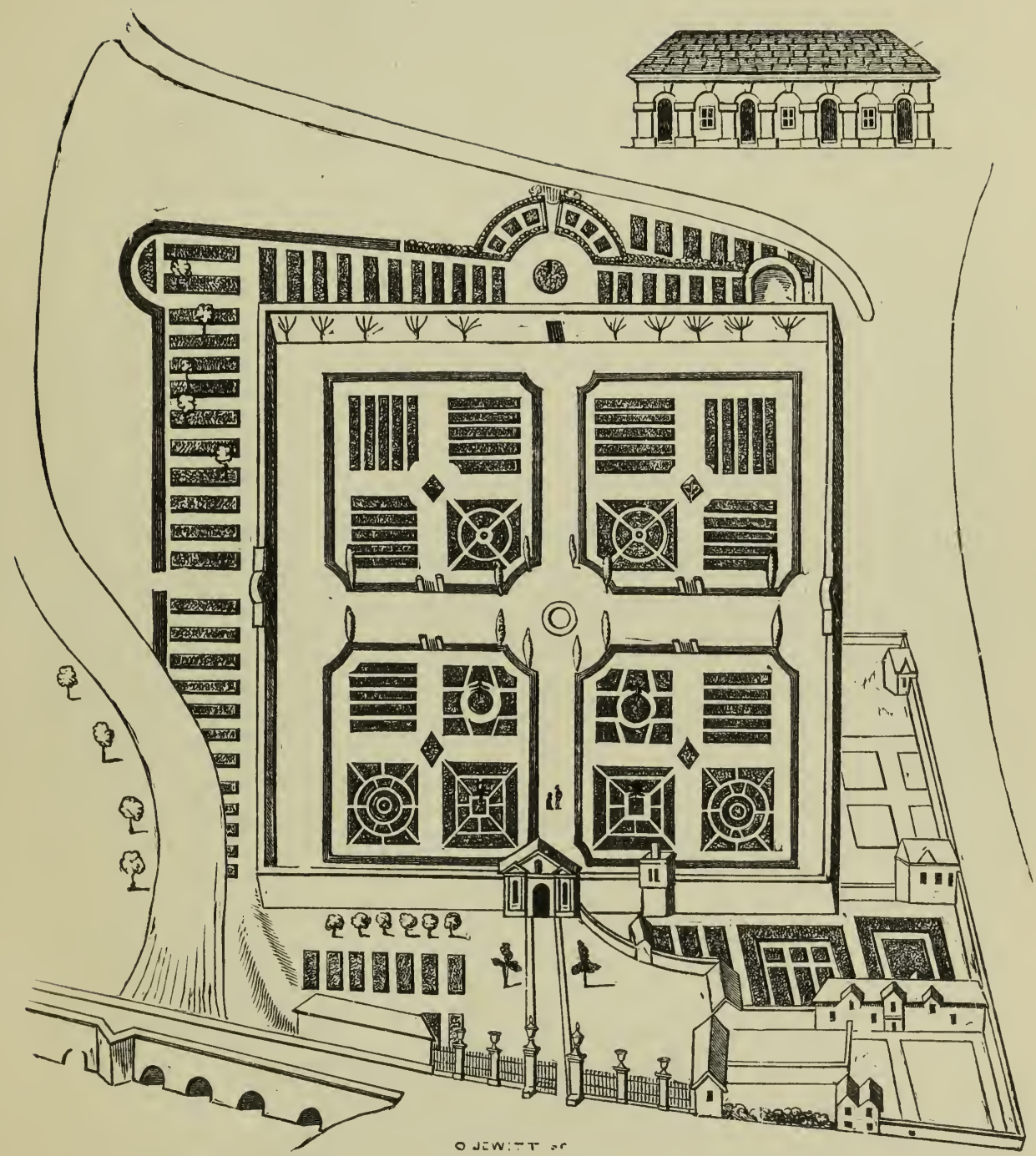

East Bridge

After Loggan's Plan of the Garden, I675 
herbs, grafts, and other curiosities to his great content" (Wood's "Athenae").

The art of grafting was also practised in the Garden by "The Reverend and Ingenious Robert Sharrock, LL.D. and Fellow of New College, who, after many unsuccessful tryals of grafting one Fruit upon another, made at last a very pleasant one, and to good advantage too, upon different Vines, which in so great measure answer'd their hopes, that they have now signal proof in the Physick Garden of the white Frontiniac grafted upon the Parsly Vine, growing and bearing very well; and to this advantage, that they think the early ripening stock of the Parsly Vine to conduce somewhat to the earlyer ripening of the white Frontiniac, naturally late.

"They have also grafted the early red-cluster or Currant grape upon that large, luxuriantly growing Vine, called the Fox-grape, which seems to produce much fairer and stronger Fruit than that grape is usually upon its own stock" (Plot, l.c.).

The plan on page 7 , taken from Loggan, and published in r675, will serve to show the manner in which the Garden was laid out at the period of its original foundation, and the Conservatory for tender exotic plants, 60 feet long. It backed on to the High Street, to the eastward of the Danby gateway, and was covered with a roof of stone slates.

In Bobart's time, fashion in gardening was setting in in favour of the stiff symmetry, geometric walks, clipped shrubs, and the buxus multiformis of Pliny. Nor were other gardens without their examples of topiary art: "a Dial cut in Box was a rareity in New College: in Exeter Garden they fashioned their College arms in the same material. British gardeners," wrote a Fellow of Magdalen, * who must have seen the Garden within a few years of the death of Bobart, "instead of humouring nature, love to deviate from it as much as possible. Our

* Addison, "Spectator," No. 414, I7I2. 
trees rise in cones, globes, and pyramids. We see the marks of the scissars upon every plant and bush."

The suffering eye inverted nature sees,

Trees cut to statues, statues thick as trees.-POPE.

Two large yews were clipped to represent two giants guarding the entrance to the Garden, which were the subjects of much rival wit in the University. Three ballads appertaining to them are preserved in "Wood's Collection" among the Ashmolean books. (For one, see Appendix A.)

A matter of far greater scientific importance is the claim of the Oxford Garden to a share in the discovery of the sexuality of plants, which was first clearly demonstrated by experiment by Camerarius of Tübingen in $\mathbf{I 6 9} \mathbf{I}-4$. More than a decade earlier our Oxford Sedleian Professor of Natural Philosophy, Sir Thomas Millington, suggested to Grew * that the stamens or attire "served as the male for the generation of the seed"; and Dr. Daubeny inferred, with some probability, that the facts by which Millington had arrived at this conclusion would be drawn from observations made on plants growing in the Botanic Garden of his own University, then recently founded. Unfortunately, we have none of Millington's own botanical writings ; and Grew had a habit of mixing up his botany with the fantastic chemical theories of his contemporaries.

On the death of Morison in 1683, the son of Bobart, also named Jacob, succeeded to the chair of botany, and continued the labours of his predecessor by the publication of the third part of the Oxford History of Plants.

Jacob Bobart, the younger, appears to have been the first to circulate an Oxford Seed-list $\dagger$ among the gardeners of

* Grew, "Lecture on the Anatomy of Flowers," "Philosophical Transactions," Nov. 1676.

† A copy is still extant in the British Museum (Sloane MS. 3343), where, too, are preserved forty-two of his letters to Sir Hans Sloane and to James Petiver, F.R.S., who dedicated to him Table xiii. of "Gazophylacii Naturae et Artis," 8vo, London, I702. The poem en- 
his day - a practice which was revived two centuries later, with good results to the Garden, and he even advertised his seeds in the papers :

"Good new St. Foyn Seed may be had at Mr. Jacob Bobart's, at the Physic Garden, in Oxford" (London Gazette, No. 2633, Feb. 5, 1690).

Nevertheless, the Garden does not seem to have been quite up to the mark as compared with other gardens. It may be that he devoted his energies to literary and professional duties rather than to the Garden, or perhaps he lived during a period unfavourable to vegetation. During the winter of I682-3 there was so great a frost that "oaks, ashes, walnut-trees were miserably split and cleft, so as they might be seen through, and this also with terrible noises, like the explosion of fire-arms, and that the clefts were not only in the bodies, but continued to the larger boughs, roots, etc." *

Then, too, the Garden was overstocked with shrubs of fanciful forms-

\section{In living trees,}

Here frowns a vegetable Hercules.-TICKELL.

titled "Vertumnus," I 7 I3, by Dr. Evans, the author of "The Apparition," is a eulogium on him. Vicia bobartia and the Grass genus Bobartia were named after him by Forster and Linnaeus respectively. His Herbarium of about 2,000 specimens is the oldest collection but one of dried plants in the University Herbarium. An amusing anecdote is preserved by Dr. Zachary Grey in his notes upon "Hudibras," i. p. 25 :

"Mr. Jacob Bobart did about forty years ago (in 1704) find a dead rat in the Physic Garden, which he made to resemble the common picture of dragons, by altering its head and tail, and thrusting in taper sharp sticks, which distended the skin on each side till it mimicked wings. He let it dry as hard as possible. The learned immediately pronounced it a dragon, and one of them sent an accurate description of it to Dr. Magliabechi, Librarian of the Grand Duke of Tuscany. Several fine copies of verses were wrote upon so rare a subject, but at last Mr. Bobart owned the cheat. However it was looked upon as a masterpiece of art; and as such, deposited in the Museum, or Anatomy School, at Oxford."

* "Philosophical Transactions," ı683 ; Cater, "Horti Bot. querela." 
Sorbière, a French physician travelling in $\mathrm{I} 664$, considered the Garden "more like an orchard than a garden." *

Zacharias Conrad von Uffenbach $\uparrow$ visited the Garden in August, I 7 Io, and found it full of plants, but with few rarities.

Like other visitors he mentions the fine yews, the best he had seen on his travels, and describes Hercules at one end and a pair of flower-vases standing on columns at the other. But what surprised him most was the appearance of the Professor, which ill accorded with the high esteem in which he was held. "Bobart," wrote Uffenbach, " had an ugly type of countenance and an evil appearance. His nose was unusually. long and pointed, eyes small and deeply sunk, mouth awry, with next to no upper lip, a great deep scar furrowed his cheek, and his face and hands were as black and coarse as those of the veriest labourer. His clothes, and especially his hat, were in bad state, and his wife, who accompanied him, was old and dirty. Such was the aspect of the Herr Professor that no one would have taken him for anything but a gardener, and, as a matter of fact, he devotes himself principally to garden work, and also, with praiseworthy energy, to bringing out the book of his predecessor, Morison. But he is a good horticulturist rather than a scientific botanist.

"He showed us round the garden and all that he had with great willingness. There were a great number of plants, but the collection was not equal to that at Leyden or at Amsterdam. The arrangement was nothing remarkable, but somewhat irregular. The rarer plants were all grouped at the end of the garden in an enclosure and behind the house; in the middle of the garden were common culinary vegetables-run wild. Behind the house in which he lived is a small garden and a small Orangery, built of stone in the centre, but with a small

* Boase's " Oxford." But Celia Fiennes, circ. 1695, found great diversion and pleasure : "the variety of flowers and plants would have entertained one a week." She also described the new Library.

$\dagger$ Z. C. von Uffenbach's " Reise," Ulm, I754. 
glasshouse on either side, which were not badly warmed by the sun, and where plants were protected from cold. In summer they were used for forcing. The whole appearance was satisfactory. Bobart complained that two years previously he had lost many plants through frost, to which Herr D. Büttner answered very neatly, that that cold winter had done much injury to Botany, for it had not only removed very many plants, but also three eminent Botanists, Tournefort in Paris, Hotton in Leyden, and Trionfetti in Rome.

"Bobart showed us an Amygdalum Nanum Aegyptiacum flore pleno, saying that when it first arrived, Mr. D. Hermann of Leyden was with him in Oxford, and when he saw the plant his eyes filled with tears and he called out, 'That is my plant.' And that was quite true; for the ship with it and with many other plants which he had himself collected with the greatest trouble in India, had been captured by a French privateer, and a selection of them found their way to Oxford." We are glad to think that Bobart restored a few to the possession of their rightful owner, Mr. Hermann. Uffenbach also noticed a small stone basin in the middle of the small garden, in which some green thing floated on the water. Bobart asked him if he did not know the saying Vilior alga, for this was an Alga which grew floating in the water.

The less critical Dr. John Ayliffe, however, gave the Garden a better character in I $7 \mathrm{I}_{4},{ }^{*}$ stating that it contained many thousands of plants " for the Use and Honour of the University ; serving not only for Ornament and Delight and the pleasant Walking and Diversion of Academical Students and of all Strangers and Travellers; but of great use also, as is easily found, among all Persons willing to improve their Botanical inclinations and studies; and for the pleasant Contemplation and Experience of Vegetative Philosophy, for which is here supposed to be as good Convenience as in any Place of Europe (if not the best) and also for the service of all Medicinal Prac-

* "The Antient and Present State of the University of Oxford," I 7 I4. 
titioners, supplying the Physicians, Apothecaries and who else shall have occasion for things of that nature with what is right and true, fresh and good for the Service of Health and Life."

Bobart was compelled to resign his Professorship in or shortly before March, I 7 I9, according to a letter of Consul W. Sherard, by the Vice-Chancellor, Dr. Skippen, Principal of B.N.C., and he died shortly after on December 28 following, aged seventy-eight.* "They ought to have let him spend the short remainder of his time in the Garden" (Sherard, Letter of July 8). How frequent such cases are!

Of his two immediate successors, Edwyn Sandys, D.M. of Wadham College, and Gilbert Trowe, D.M. of Merton, nothing particular is recorded; but in the year I 728 the whole establishment was placed upon an improved footing, and its permanence more effectually secured, through the munificence of Dr. William Sherard. $\dagger$

This distinguished patron of botanical science was born in I658, and after passing through Merchant Taylors' School, entered at St. John's College, Oxford, I677, and afterwards became a Fellow of that society. He travelled much on the continent, chiefly occupied in collecting plants, and in forming connections with the most celebrated foreign botanists of the day, such as Hermann, Boerhaave, and Tournefort. Being appointed consul at Smyrna, he availed himself of the oppor-

* There is a portrait of him in the Oxford Almanack for I719. An unfeeling epitaph in Amherst's "Terrae Filius," 1726, affords a suggestion of the pronunciation of his name :

\section{Here lies Jacob Bobart \\ Nailed up in a cupboard.}

Jacob's brother Tilleman seems to have acted as Keeper of the Garden for some time. He did work for the Government in laying out gardens at Hampton Court and Blenheim Park, where he planted the elm-trees in the same order that the British troops fought against the French at the Battle of Blenheim.

$\dagger$ B. D. Jackson has a notice of him in "Journal of Botany" for May, 1874. An unnamed portrait in the Botanical Library may be of him. 
tunities which his residence in the East afforded, to collect the plants of Natolia and Greece, of which the dried specimens still exist in his herbarium preserved at the Botanic Garden. On his return he met with the celebrated I)illenius, whom he induced to accompany him to England in I72I; and in the year 1726 he commenced his designs for the advancement of botany at Oxford, by giving $\notin 500$ towards enlarging the conservatory, and by presenting a great number of curious plants and a library of botanical works to the same establishment. He likewise made over to the Physic Garden an herbarium, which rendered Oxford, in the eyes of Linnaeus, pre-eminent in this respect among the Universities of Europe ; containing, as it did, original specimens from most of the eminent botanists of that day, named by themselves, and accompanied by their rernarks, or by queries, says Sir E. G. Sinith, scarcely less instructive. On his death, which took place two years afterwards, Sherard was found to have bequeathed $\mathcal{E}_{3}, \infty 00$ to provide a salary for the Professor of Botany, on condition that the University should supply the annual sum of $\mathcal{E}$ i5o towards the maintenance of the Garden, and that Dr. Dillenius should be chosen the first Professor - terms which were accepted by Convocation.

The Garden, as it existed in Sherard's time, was divided into quarters, by means of a double yew hedge which extended from the principal gateway to the opposite extremity, and of a similar one, which ran from east to west, intersecting the former at right angles. Between these hedges the public were allowed to walk, and there was at one time a thoroughfare into Christ Church meadow through the centre. But the square plots of ground enclosed within these hedges, which contained the plants, appear to have been less easy of access, and to have been kept under lock and key. Of these hedges, the one which extended across the Garden from east to west was cut down in the time of the younger Dr. Sibthorp; whilst the other, which divided the Garden longitudinally, remained 


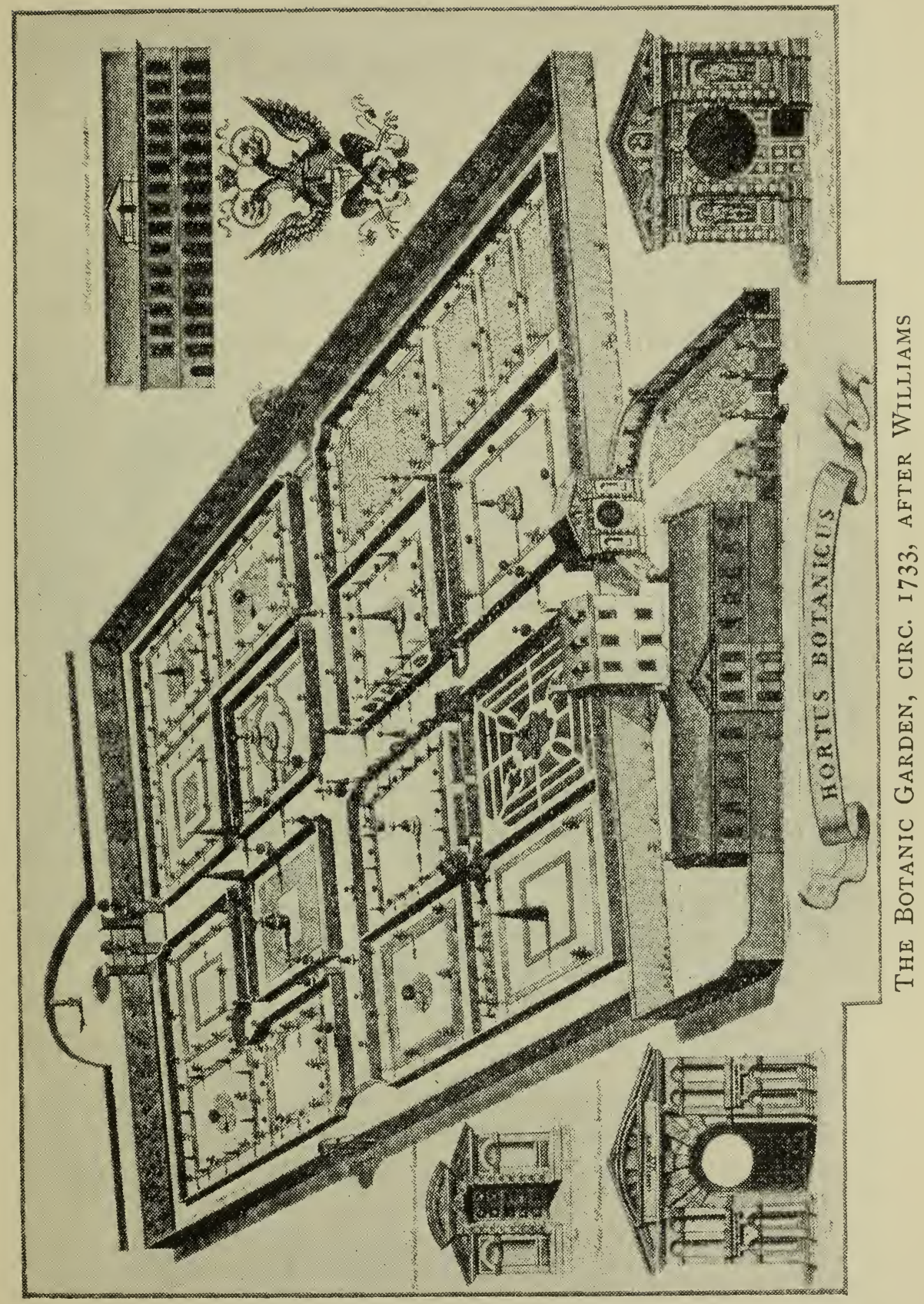


standing till the year 1834 ; when, having lost much of its former beauty, and being in the way of new arrangements, it shared the same fate.

The arrangement of the Garden is shown in detail in W. Williams' engraving in "Oxonia depicta," plate 8, which must have been drawn about I 733 .

At this period there appears to have been a long building fronting the street, first used as the conservatory, but afterwards,

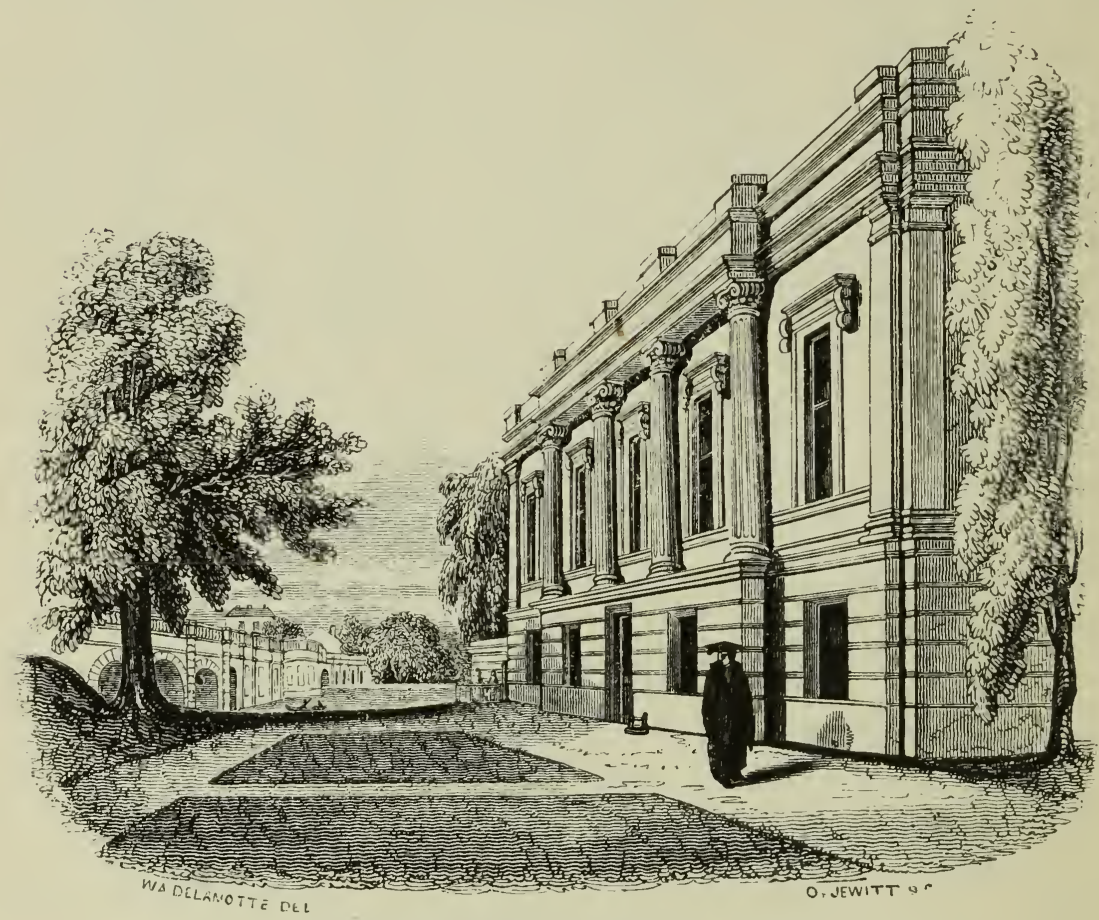

The Professor's House, I 835

by the addition of an upper story, converted into a receptacle for the herbarium, and into a residence for the Professor. This building having been pulled down about the year I790, by order of the Street Commissioners, in order to improve the approaches to the bridge, then recently erected, the original intention of the founder of the Professorship as to the residence of the Professor at the Garden, was for nearly half 
a century departed from, until Dr. Daubeny, soon after his accession to office, erected a new dwelling-house at the back of and over the Library. The annexed wood-cut presents the façade.

'This building originally comprised a lecture-room, as well as apartments for the Professor's private use, and received the collection of books belonging to the establishment; the whole, however, was soon given up for the purposes of a dwelling-house, as in 1847 the society of Magdalen College permitted Dr. Daubeny to erect a building upon their own ground, on the opposite side of the gateway, in which his lectures were henceforth delivered.

In compliance with the terms of Dr. Sherard's will, Dillenius was appointed, on Trowe's death, Sherardian Professor in the year I 734, and was admitted to the degree of D.M. in I 735.* In 736 he received a visit from Linnaeus, whose new system

* J. J. Dill, Dillen, or Dillenius, b. Darmstadt, I684, F.R.S. I724, M.D. Oxon. I735, was educated at the University of Giessen, and published a catalogue of the plants growing in that neighbourhood, a work which established his reputation as a botanist. He also communicated various memoirs to the Academia Naturae Curiosorum, which appear in their Transactions, called "Miscellanea Curiosa." But his great strength lay in cryptogamic botany; and this, which attracted the attention of Sherard, who was himself attached to this department, led him to invite him to England. Whilst in this country, he engaged himself in the task of describing and delineating the rare plants contained in the garden at Eltham, near London, belonging to Dr. James Sherard, the brother of his patron, who was likewise an enthusiastic botanist. This splendid publication appeared in 1732 , in two vols. folio, under the name of "Hortus Elthamensis," and was pronounced by Linnaeus one of the most complete works of its kind ever published. Dillenius also brought out a new edition of Ray's "Synopsis," with sundry additions; but his most important work was the "Historia Muscorum," which he brought to completion at Oxford, and published at the Sheldon Press in I74I. All the subjects noticed in this volume were drawn and etched with his own hand; and, in spite of subsequent improvements, the labour, accuracy, and discrimination displayed throughout the whole work will prevent it from ever becoming 
of botany he did not choose to countenance,* "conceiving Linnaeus' 'Genera ' to be written against him, but he afterwards detained him a month without giving Linnaeus an hour to himself the whole day long; and at last took leave of him with tears in his eyes, after having given him the choice of living with him till his death, as the salary of the Professorship was sufficient for them both." $\uparrow$ Their intercourse produced a mutual respect for each other's acquirements, and led to a correspondence which seems to have continued to the death of the Oxford Professor in 1747. After his return home Linnaeus wrote, "In Anglia nullus est qui genera curet vel intelligat praeterquam Dillenius," "and he founded the genus Dillenia, of all plants the most distinguished for the beauty of its flower and fruit, like Dillenius among botanists." +

Dillenius had such an enthusiasm for plants that he was in the habit of scattering strange seeds about in the neighbourhood of the city: some of their descendants have caused surprise to later generations of botanists. So it was but natural he should remove the cause of Uffenbach's reproach.

obsolete. He was buried in the churchyard of St. Peter-in-the-East, and there is a tablet to him near the south door of the church.

An oval portrait of James Dillenius, M.D., holding an Amaryllis flower in his hand, measuring $4 \frac{1}{4}$ in. $\times 3^{\frac{1}{2}}$ in., was engraved by Jas. Heath from the original painting in the Botanic Garden in Oxford.

* Linnaeus, it is said, surprised Dillenius in company with his patron, Dr. Sherard, and, having apologised in Latin for his inability to speak English, threw Dillenius off his guard, who said carelessly to Sherard, "This is the young man who would confound the whole of botany." Linnaeus gathered the meaning of this speech by tracing the verb confound to its Latin root, and he soon took an opportunity of retaliating, by slightly alluding to it while he was demonstrating in the Garden some of the new genera to which Dillenius had particularly objected. He quickly constrained the Oxford Professor to form a high opinion of his abilities, but could never succeed in making him a proselyte. There are two or three variants of the story.

† Linnaeus' Diary, 517, quoted in Druce's "Flora of Oxfordshire."

‡ Druce's "Flora of Berkshire." Also cf. his "Dillenian Herbarium," I907. 
And we find that by the end of his custodianship there was no lack of rarities in the Garden. There were these "Curiosities among many other scarce and rare exotics of all kinds.

r. The true African Rhubarb.

2. The Aloe Plant, with a white Flower on it. 'The Aloe is so succulent a Plant, that it has been preserv'd Io years above ground without either earth or water, and 'tis thought may be preserv'd so 20 years, as I was inform'd by the late excellent Botanist $\mathrm{Mr}$ Bobart, Master of this Garden.

3. The true Indian Tobacco Plant, and Indian Wheat.

4. Guinea Pepper 'Tree.

5. Pomum Amoris.

6. Sorbus Vera, the Sorb or Quicken Tree.

7. Helianthemus or Sun-Flower, of a fleshy colour and five leaves.

8. Scylla vera which was a six leav'd Flower almost of a lead Colour.

9. Arbor Balsami Peruviana.

10. Cedrus Vera, from Mount Lebanon with leaves like a star; rais'd from a seed, as the aforemention'd Tree was.

I I. Paliurus or Thorn with which our Saviour was crowned, as Mr Bobart told me he has great Reason to believe. It grows in the Corner between the Gate and the House.

I2. Pistacia Vera, the true Pistacia Tree, with leaves like a walnut.

13. The Currant Grape grafted upon the Fox-Grape.

I 4. The White Frontiniac Vine, grafted upon the Parsley Vine.

I5. The Sensible Plant call'd by some the Chaste Plant, because if it be touched the jagged part of the leaves shrink and run together as if they were wither'd, but when the hand that touch'd it is remov'd, it opens itself and thrives again. This unaccountable plant grows in the Island Barbada in North America. . . . 
r6. And besides these Natural Curiosities, here are several instances of Nature improved by Art, as Trees cut into curious shapes. I 7. To which we may add the curious piece of Rustic Rock-work over the Gate on each side of which are the Statues of King Charles I. and II. and over all the Earl of Danby's Statue in Busto, the founder of this Garden. I8. Another curiosity are the Sphinges Megaricae, on each side of the Iron Gate that leads into the Court before the Garden, which Sphinxes are Hieroglyphics (says the learned Montfaucon) and Emblems of Wisdom." *

Dillenius was of a retired disposition, and recluse habits. His corpulency, combined with his close application to study, probably brought on an attack of apoplexy, which terminated his existence in the sixtieth year of his age.

Of his successor, Dr. Humphrey Sibthorp, of Magdalen College, little notice is preserved; he gave "one not very successful lecture ... and every scientific object slept during the 40 years he held the post." $\uparrow$ The genus Sibthorpia (Linn.) was dedicated to him and not to his son. The latter, John Sibthorp, M.D. of Lincoln College, appointed to the chair in 1784 , will be ever memorable in the annals of botany for his zeal in the pursuit of science, no less than for his munificent designs to promote its advancement. The former feeling led him to undertake two journeys into Greece and the Archipelago, the first when Travelling Fellow, in $1784, \neq$ the second, when Professor of Botany, in I794.\$ On his death,

* John Pointer's "Oxoniensis Academia," I749.

† Sir James Smith, quoted from Druce's "Flora of Oxfordshire."

\pm It was perhaps during Sibthorp's alssence that one of the first balloon ascents in England was made from the Physic Garden. On Nov. I2, I784, Mr. Sadler went up, watched by " a surprising concourse of people of all ranks; the roads, streets, fields, trees, buildings, and towers of the parts adjacent being crowded beyond description."

$\S$ In the first of these journeys he engaged at Vienna, as draughtsman, the celebrated Ferdinand Bauer, with whom he visited Constantinople, Crete, Cyprus, and other islands of the Grecian Archipelago. $\mathrm{He}$ also 
in 1795, he evinced his anxiety for the future advancement of his favourite science by making over to the Botanic Garden all his drawings, books of natural history, and collections : and still more by bequeathing a freehold estate, for the purpose, first, of publishing his "Flora Graeca," in ten folio volumes, with roo coloured plates in each; and afterwards of endowing a Professorship of Rural Economy in Oxford, which was to be held by the Professor of Botany for the time being.

The work was only completed after the lapse of more than forty years from the time of his decease, but as the great cost limited the original subscribers to a very small number, $\mathrm{Mr}$. Henry Bohn, the publisher, was allowed the use of the copper-plates, in order to enable him to bring out a second edition on more moderate terms.

We must not omit to mention James Benwell, in the employ of the Garden, whose portrait adorns the library. He attended Sibthorp on his botanical excursions in the country and discovered some rare plants. "His integrity, industry, and a

travelled over a considerable part of the Morea, and did not return to England till the autumn of I787. The value of the services which Dr. Sibthorp had rendered to botany during these travels was generally appreciated, and in consideration of them the Crown made an addition to his stipend as Professor in I793. This augmentation, consisting of $£$ IOO per annum, exclusive of the same sum granted towards the keeping up of the Garden, was then charged on the privy purse; but has since been annually voted by Parliament. Dr. Sibthorp, convinced that much remained to be done for the completion of his great undertaking, set out a second time, in I794, for the same country, attended by Francis Borone, as botanical assistant, and accompanied by his friend Mr. Hawkins. With them he visited Bithynia, Mount Olympus, the Troad, the isles of Lemnos and Imbros, Mount Athos, Attica, Patras, and Zante. Of the following year they spent two months in Morea, after which Dr. Sibthorp parted from his companion, Mr. Hawkins, and returned to England by Otranto. A severe cold caught during the voyage to that port brought on a pulmonary affection; which, after his return to England, carried him off in the February of the subsequent year. 
natural propriety and courtesy of manners gained him the respect and esteem of all who knew him." He died, aged eighty-four, in r8rg.

Dr. Sibthorp was succeeded by Dr. George Williams, of C.C.C., who continued in possession of the chair till his death in $\mathbf{r} 834$.

The Curator of the Garden was William Baxter, an indefatigable botanist, appointed in I8I3. During the earlier years of his curatorship "Botany had sunk at Oxford to its lowest level. Dr. Williams, although an elegant scholar, added nothing to botanical science, and for practical instruction in botany the undergraduates in Oxford had recourse to the teachings of Mr. Baxter." * He got together a nearly complete collection of living British grasses and willows and brought the collection of hardy herbaceous plants to a high level. No one better understood

The culture suiting to the several kinds

Of seeds and plants, and what will thrive and rise,

And what the genius of the soil denies.-Drynen's "Georgics."

But in Dr. Williams' time he was denied the opportunities which his talents deserved. In ${ }^{8} 5_{5} \mathrm{I}$ he retired upon an inadequate pension and was succeeded by his son, W. H. Baxter.

A letter written by Professor Schultes, $\uparrow$ of Landshut, in Bohemia, describing his visit gives us a good idea of the state of things in 1824 :

"We were anxious to take advantage of one of those clear days which are so uncommon in England, in order to visit Oxford, which is only about fifty-eight miles distant from the metropolis. We performed the distance in less than six hours,

* Quoted in Druce's "Oxford Flora," from Gard. Chron., Nov. 4, I87I.

$\dagger$ Hooker's "Botanical Miscellany," vol. i. ; also see "Phil. Mag." I829. 
though at some risk of breaking our necks. Sir J. E. Smith had been so obliging as to give us a letter to his friend, Dr. Williams, Professor of Botany and Librarian to the Radcliffe Library.

"The danger of inundation to which it is exposed, both in winter and summer, still exists. The water frequently stands knee-deep above the plants; and as the lower parts of the garden cannot be sufficiently raised without an immense expense, these portions are left quite uncultivated. The active gardener, who is a Scotchman named Baxter, devotes his attention chiefly to the Cryptogamia; partly from mortification at finding it impossible to make the garden such as he could wish. . . Mr. Baxter also cultivates with zeal the English Willows, having a living individual of almost every species, in a proper Salicetum. To the Grasses, likewise, he gives much attention; ... This industrious man,-with the assistance of three persons, each of whom receives two shillings per day,--cultivates between 4,000 and 5,000 species of plants in the wretched houses of this garden, though, in fact, there is only one stove, properly so called, and this is much too small.

"The Oxford Garden is inadequate to the purposes of botanical instruction in the present state of science."

A later critic tells us that the Garden had fallen "into bad repute, from the sorry and dilapidated condition of the houses, which its benefactors, a century back, at a time when horticulture was in its infancy, had provided for the reception of exotics"; and Dr. Williams must have been fully cognisant of the state of things, for on his death it was found that he had desired his sister and executrix to contribute $£ 500$ 3-percent. Consols to the Garden Fund.

His successor, Dr. Daubeny, thus found himself in possession of a nucleus of a fund for the improvement of the Garden, which, by means of a liberal subscription raised in the University, augmented by a contribution from the Radcliffe 
'Trustees of $\mathcal{E} 500$, was soon sextupled. It speaks volumes for the popularity, reputation, and energy of the new Professor of Chemistry and Botany that the money came in so promptly that on May r, the day of his inaugural lecture, he was able to announce over $E_{1}, 600$ in addition to the $\mathcal{E}_{500}$.*

Charles Giles Bridle Daubeny was thirty-nine years old when he was appointed on February 8, $1834, \uparrow$ to his second chair by the Electors, the President and Fellows of the Royal College of Physicians. In appointing him they no doubt felt that they could not go wrong in taking an Oxford man with a European reputation for his books on Volcanoes and on the Atomic. Theory, who had, moreover, only a month or two before, imparted to the Linnean Society the results of important research on the "Selection exercised by plants, with regard to the earthy constituents presented to their absorbing surface," who had given an excellent account of the Irritability of Plants to the Ashmolean Society, and who had made an important contribution to Walker's "Flora of Oxfordshire." $\div$

It would take too much space here to rehearse his report upon the shortcomings of the Garden, his story of useless green-houses without top light and out of repair, of extravagant management, neglected herbaria, damp books,--but the attention of those in power may well be drawn to his pietas in carrying out the express enjoinders of the Statute relating to the Sherardian Professorship, and also those of the benefactor John Sibthorp, viz. that a portion of the Garden should be devoted to plants employed in Medicine, Agriculture, or the

* Of a total of $£ 2,9748 s$. Iod., private subscribers gave $€ \mathbf{1}, 618$ : $£ \mathrm{I}, 9146 \mathrm{~s}$. IOd. was spent on the Garden and $£ \mathrm{I}, 000$ on the Library and Collections Building.

$\dagger$ But by bureaucratic oversight he was not formally elected by the University until June 25, 1840.

$\ddagger$ For a bibliography of Dr. Daubeny's works see the author's " History of the Daubeny Laboratory," Appendix D. 
Arts, and that the Professor of Botany should reside at the Garden.*

With the money raised, a new stove-house, built to the plans of Mr. Toby of Chelsea for $£ 45 \circ$, was immediately commenced; the Stone Yard, an eyesore near Magdalen Bridge, was purchased from the Street Commissioners for fi5o, only to be surrendered again for the widening of the bridge in $1882-3$; additions were made to the Gardener's House and a noisome ditch bridged over; the two round tanks for aquatics were made at a cost of $\mathcal{E} 4448$ s. $6 d$.; a porter's lodge for $\mathcal{E}$ i 78 s. 6 d., and new rooms on the north side of the Library cost $\mathcal{E} 885$, - these were among the improvements made in Daubeny's first year. An experimental garden was also laid out, and Baxter's long-cherished scheme for raising and levelling was commenced. Private benefactors sent valuable plants: among others Lord Carnarvon sent a collection of species of Crinum and Pancratium from Highclere; J. Bateman sent Orchids, and William Borrer, Aquatics; seeds were received from Dr. Wallich of Calcutta. New houses were added in the next few years, one in July, I839, and the Orchid and Victoria Lily houses in $185 \mathrm{I}$. A Botanical Museum containing specimens too large for the Herbarium and others of economic importance was also formed.

During this period the affairs of the Garden were nominally directed by a Garden Committee consisting of the ViceChancellor and Proctors, with certain medical graduates resident in Oxford, but in February, I856, the University put its Garden under a "Delegacy." So much was done and so much more needed doing that their finances were oftentimes much straitened; in fact, had the Professor not frequently put his hand into his own pocket, they would never have got on at all. Quite

* For close on thirty years the University has preferred dried herbs to a live Professor as tenant for the Professor's House at the Garden, agreeable to the policy of several Oxford Colleges, which ensures that University and College officials shall live as far from their work as possible ! 
early in his tenure of the office it was currently reported that he had spent $\mathcal{L}_{2,000}$ of his own money on the Garden. Notwithstanding, there was at any rate one member of the University who was ungracious enough to publish a grumble against the shilling entry-fee to the green-houses which the Committee had felt it their duty to impose. Daubeny's letter of March 18, 1856, to Convocation was a very satisfactory answer to his critic.

In his time the Garden was frequently the scene of receptions and social functions, as, for instance, on the memorable occasion of the Meeting of the British Association in I847, when the Garden Party was attended by Tiglath Pileser, Frank Buckland's bear, dressed up as a student of Christ Church, with cap and gown, which was introduced to Sir Charles Lyell, Prince Charles L. Bonaparte, and Milne Edwards. The Show of the Oxfordshire Horticultural Society held here in June, I839, will be long remembered in literature as having been visited by the sisters of Mr. Verdant Green.

Some of the flowers grown in 1859 may still be seen in stone carved with great skill on the corbels and capitals of the University Museum. And again much of the sculpture of I 906 was inspired in a similar manner.

Many are the references in biographies to parties at Dr. Daubeny's "pleasant residence" at the Botanic Garden. During his later years Dr. Daubeny kept monkeys in a cage let into the Danby gateway, which were shown to guests after dinner. One night it was found that the door had been forced and the monkeys liberated. The Professor was much vexed, but did not discover the culprit, whom 'Tuckwell believed to be Harry Wilkins of Merton. The monkeys were captured next day "wandering dismal on the Iffley Road, or perched, crepitantes dentibus, on the railings in Rose Lane." The Oxford Chronicle for January I 8, I 868, contained the unusual announcement of the "Sale, by Dr. Daubeny's executors, of furniture, old wines, some of the pictures, MONKEYs and CAGE, and 
valuable miscellaneous effects. At the Botanical Gardens, Oxford."

Dr. Daubeny, in the words of his biographer, lived to see the old Garden entirely arranged, enriched with extensive houses, extended in area, and made both attractive and beautiful.

Yet Professor Phillips, in an Obituary Address to the Ashmolean Society, stated-and no one was in a better position to know-that the delightful study of plants, which tempted the great Swedish naturalist to visit most of the gardens of Europe, would hardly induce a resident in Oxford to pass beneath the graceful arch which records the foundation among us "of what was once, and perhaps may be again, considered to be one of the most important of the Natural History studies approved by the University."

Dr. Daubeny's successor, Mr. M. A. Lawson, * was not the man to impress his contemporaries with the importance of his subject. His energies were principally directed to the classteaching of microscopic anatomy and histology of plants, less to the care of the Garden.

The early seventies were very critical years in the history of the Garden. The entire family of the Natural Sciences had assembled in the University Parks, to the mutual assistance and great contentment of its members. Botany was the only absentee from the circle. Her presence was urgently required to aid the Palaeontologist with his fossil plants, the Physiologist with material for vivisection without licence, students in general and botanical students in particular with a garden in which they might, without loss of time, gather valuable information and maintain health while (as Sir J. E. Smith expressed it) "conversing with God in the garden of Creation."

* Born at Seaton Carew, co. Durham, I840; M.A. Trinity College, Cambridge. He died as Director of the Botanical Department, Ootacamund, India, at Madras, I896. 
The idea was that five acres might be railed off from the Parks as a "Garden of Instruction" while a newly planted and carefully chosen series of trees would become in time a useful Arboretum, without additional cost. Moreover, the Botanic Garden would then be the actual property of the University instead of the property of Magdalen College. Sir William Hooker and Professor Daubeny were reported to have favoured the idea of the move.

In 1873 the Garden Committee consulted with Dr. Hooker, Director of the Royal Gardens, Kew, who reported upon various plans, and gave it as his opinion that as the erection of new Glass-houses had become absolutely necessary, even if the Garden were to be retained upon its ancient site, the expense of making a new Garden would be some $\mathcal{E}^{2,000}$ greater than the repair and improvement of the old Garden; and that, moreover, the Professor would lose his official residence. On the whole Dr. Hooker was adverse to the removal of the Garden,** and Professor Lawson, on second thoughts, was with him.

Dr. Acland took the matter up with characteristic energy. His life-scheme of a united Scientific Institute in Oxford with the grand design of the development of a complete national education in science was in danger of remaining incomplete - perhaps for ever.

On Tuesday, May 23, I876, the University settled the question by voting $\mathcal{E}^{2,200}$ for the new Class Room and Laboratory, and for reffitting the Herbarium as a Lecture Room, and thus the Garden and Laboratories, according to the words of Dr. Acland, remained "on a leasehold, apart from the rest of the Scientific apparatus of the University, but attached to the Scientific Department of Magdalen."

* "A Letter to Dr. Hooker, Director of the Royal Gardens at Kew, President of the Royal Society," 2nd edit., published by James Parker \& Co., Oxford and London, I875. The first imprint of this second edition contained a personal remark for which it was recalled. We reprint the effective skit on it as an Appendix. 
The building of the new Glass-houses, although strongly recommended by Lawson and his successor, was not as a matter of fact commenced until 1893 .

During the fourteen years of Mr. Marmaduke Lawson's tenure of the chair, but few improvements were made in the Garden, nor was the output of scientific work considerable. One fact, however, is well established, and that is that just before Professor Lawson's departure to a new post in India, he caused an irreparable loss to the Garden by the disposal of the gems of the succulent collection, unique specimens, to Kew.

An incident of more than passing interest was the inauguration of the Oxfordshire Natural History Society, founded by Mr. G. C. Druce and Professor Westwood, in the Lecture Room on May 27, I880. Professor Lawson was in the chair.

During I883, before the election of Professor Lawson's successor, one of the Curators, Mr. Edward Chapman, of Magdalen College, took entire charge of the Garden. He saw to the auditing of the accounts, paid the bills, delivered lectures on Vegetable Physiology to undergraduates reading for the Honour School of Natural Science, and superintended their practical work with Mr. C. H. Wright, acquired and obtained reports upon Baxter's extensive Herbarium, recorded the flowering of the Aloes, got a guide convicted of wilfully plucking flowers and fined Ios. and costs, and reported to his colleagues.

In the leading horticultural journal appeared the notice: "For the first time in our remembrance we have received a report of the Oxford Botanic Garden, and, in so far an interregnum, seems to have advantages over a regular government." We might go a step further in the direction of the definite, and add that government by one man who knows and has the real interests of his work at heart has advantages over government by members of a committee chosen because there is nobody else, and they happen to be there! 
Professor Balfour, * unfortunately, was not with us long enough to carry through all his intended reforms, but the Report published by him upon the state of the Garden was of assistance to those who came after. The systematic herbaceous beds were remodelled under his direction.

The changes were not popular with every one, but they hardly merited the biting words of Tuckwell : "New brooms swept the unique old Garden clean; young men arose who knew not Joseph; young men in a hurry to produce a little Kew upon the incongruous Cherwell banks. So Baxter fils was cashiered, the I,innean borders razed, the monumental plants uprooted."

With the appointments of Dr. Vines as Professor and of

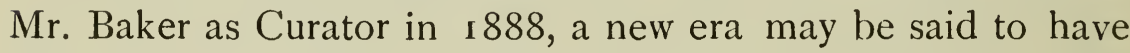
commenced. The University, after turning deaf ears to the reports of Committees and Professors for a score of years, at length voted the much-needed money for new Glass-houses.

In 1889 a Seed-list was compiled by Mr. Baker, and was printed and circulated far more widely than its predecessor 200 years before. The advantage to the Garden was great and immediate - in fact, in the first year the Garden received 880 plants and 930 packets of seeds. The labour involved by this branch of garden work alone may be gathered from $\mathrm{Mr}$. Baker's figures published with the Curators' annual reports, from which it appears that in the twenty-one years since the appearance of the annual Seed-list the Garden has distributed 1 2,827 plants, 2,416 bulbs, and 69,72 I packets of seedsreceiving in exchange 10,887 plants, 3,148 bulbs, and $37, \mathbf{1} 49$ packets of seeds.

During the same period the increase of the Medical School, and, more recently, the transference to Oxford of the School

* Born I853 ; M.D. Edin., D.Sc., F.R.S. ; Regius Professor of Botany, Glasgow, 1879-84; Sherardian Professor, Oxford, I884-8; Regius Professor of Botany, Edinburgh, and King's Botanist in Scotland, since 1888. 
of Indian Forestry from Cooper's Hill, have so greatly swelled the numbers of undergraduates studying laboratory botany that the very limited accommodation in the old buildings at the Garden proved insufficient, and the present scheme was evolved, of teaching parts of the science at four different centres outside the Garden.* It is an unfortunate plan, wasteful alike of University and College funds and space, and of the time and energy of teachers and students. For such mismanagement the Hebdomadal Council and the Oxford system of government by Committees are principally to blame. They have promulgated no comprehensive scheme for the development of botanical science, nor does it appear likely that any single member of that Council can have the time during the present period of frenzied legislation to study fully the needs of all its multifarious departments or the true relationships between them and the other scientific departments of the University.

But it is with the open-air Garden that we are now more immediately concerned. Let us hope that better and better uses may be made of the ground available, always bearing in mind the purposes for which it was originally intended, and for which generations of benefactors have given of their wealth. It is none too large for the purpose : plot after plot cannot be sacrificed to the ever-increasing number of branches of the science and to the apparatus necessary for their study, without damage by corrosion to the ancient institution in which we take so much pride.

Less than twenty years ago the University of Oxford could boast the possession of three venerable institutions, the Bodleian Library, the Ashmolean Museum, and the Botanic Garden, each the oldest of its kind in England and among the oldest in Europe. Visitors from all parts of the civilised world come

* Department of Comparative Anatomy, at the University Museum ; Department of Rural Economy, Parks Road; Department of Pathology, Parks Road ; and the Daubeny Laboratory of Magdalen College. 
expecting to see original collections in original cases in coeval buildings. By the vandalism of 1894 this unique arrangement was destroyed at the Museum, and with the approval of the Keeper, and so only two out of the three institutions remain in anything like their original condition. With such an example before our eyes we should be the more careful of our unique heritage at the Botanic Garden. Let us endeavour to preserve it as one of those precious memorials of the past which our visitors expect to find in Oxford. Let us not aim at employing our limited means in making a third-rate imitation of the speciality of others; let us rather cherish whatever of the distant past is still left to us, and let incongruous modern developments seek ground elsewhere.

In the future perhaps we may hope to see a further extension southward in the direction of the walks round Christ Church meadow, and, with the concurrence of that House, the planting there of varieties of hardy trees and larger shrubs, for which there is no room within the walls, to form an Arboretum worthy of the oldest Botanic Garden and University in England. On the Cherwell eyots too, both above and especially below Magdalen Bridge, there is room not only to re-establish Baxter's Salicetum, but for water-gardens and collections of marsh plants such as no horticulturist has yet seen.

The Cherwell, with his occasional floods, may be trusted to do his part, for either-

In ninefold volume now, a Stygian stream,

Uncertain of his willows Cherwell glides

Athwart his vale, and o'er his wanderings

A dense white level pall of mist is spread.-W. MOore.

Or,

He makes sweet music with the enamelled stones,

Giving a gentle kiss to every sedge

He overtaketh in his pilgrimage,

And so by many winding nooks he strays

With willing sport to the wild ocean.-BrownING. 


\section{THE HARDY PLANTS}

The arrangement of the Oxford Garden is always changing-

Times do change and move continually,

So nothing here long standeth in one stay:

Wherefore this lower world who can deny

But to be subject still to mutability.

Bobart's Garden was divided into small beds by many paths, as shown in Loggan's plan of 1675 , and roughly indicated in his reduced plan, reprinted on p. 7 . The total length of beds must have exceeded 10,000 ft. Later, the number of clipped shrubs was increased and the arrangement of the beds altered (cf. IVilliams' plan, p. I5). The chief interest of the Garden lay in its medicinal herbs, and no doubt the grouping of the plants followed the views of the herbalists. In these early days many more species and varieties of hardy plants seem to have been grown, than is the case at the present day, but then there were no large trees. An early list of species is preserved in the British Museum (MS. Sloane, ro38).

Later the results of the travels of scientific botanists such as Sibthorp bore fruit, and the purpose of Botanic Gardens came to be considered to illustrate the floras of the different regions of the world. And so, by the beginning of the nineteenth century, the arrangement of the Garden had come to be primarily a geographical one, and secondarily according to the various kinds of plants, whether trees, perennials, or annuals.

In the thirties, Dr. Daubeny caused the beds to be rearranged so that the plants might be disposed with reference to their natural affinities; but of course the older shrubs and trees necessarily remained as before, and traces of the 
geographical method may still be noted. According to his impartial scheme (1834) the Linnean Classification was illustrated by the eastern half, the Natural System as stated by De Candolle, by the western half of the Garden, but the Materia Medica and Grasses were outside the walls, beyond an Experimental Garden which was also laid out there by Dr. Daubeny.

Modifications to meet the views of practical horticulturists such as Baxter and his successors have from time to time been made, but the systematic grouping has on the whole been fairly maintained.

S. Gate

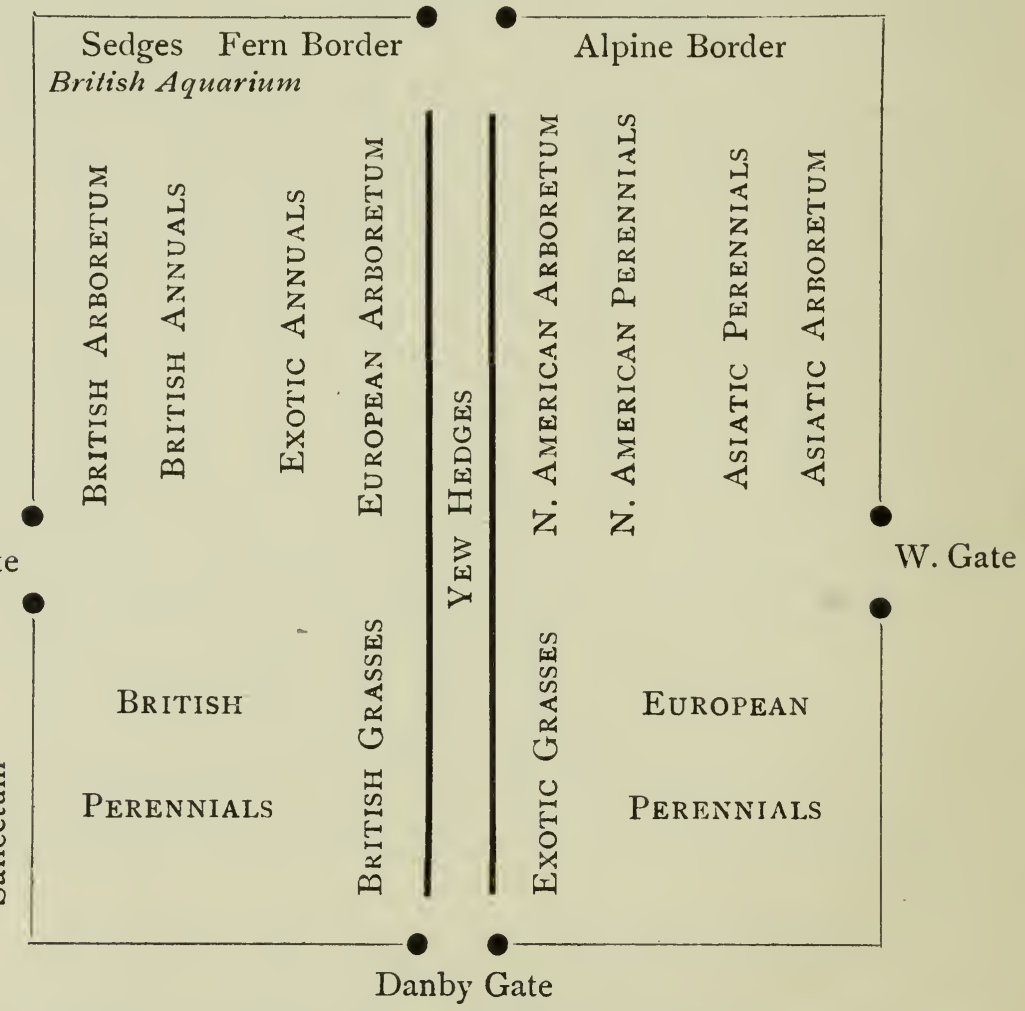

The Oxford Botanic Garden in the Early Part of the Nineteenth Century 


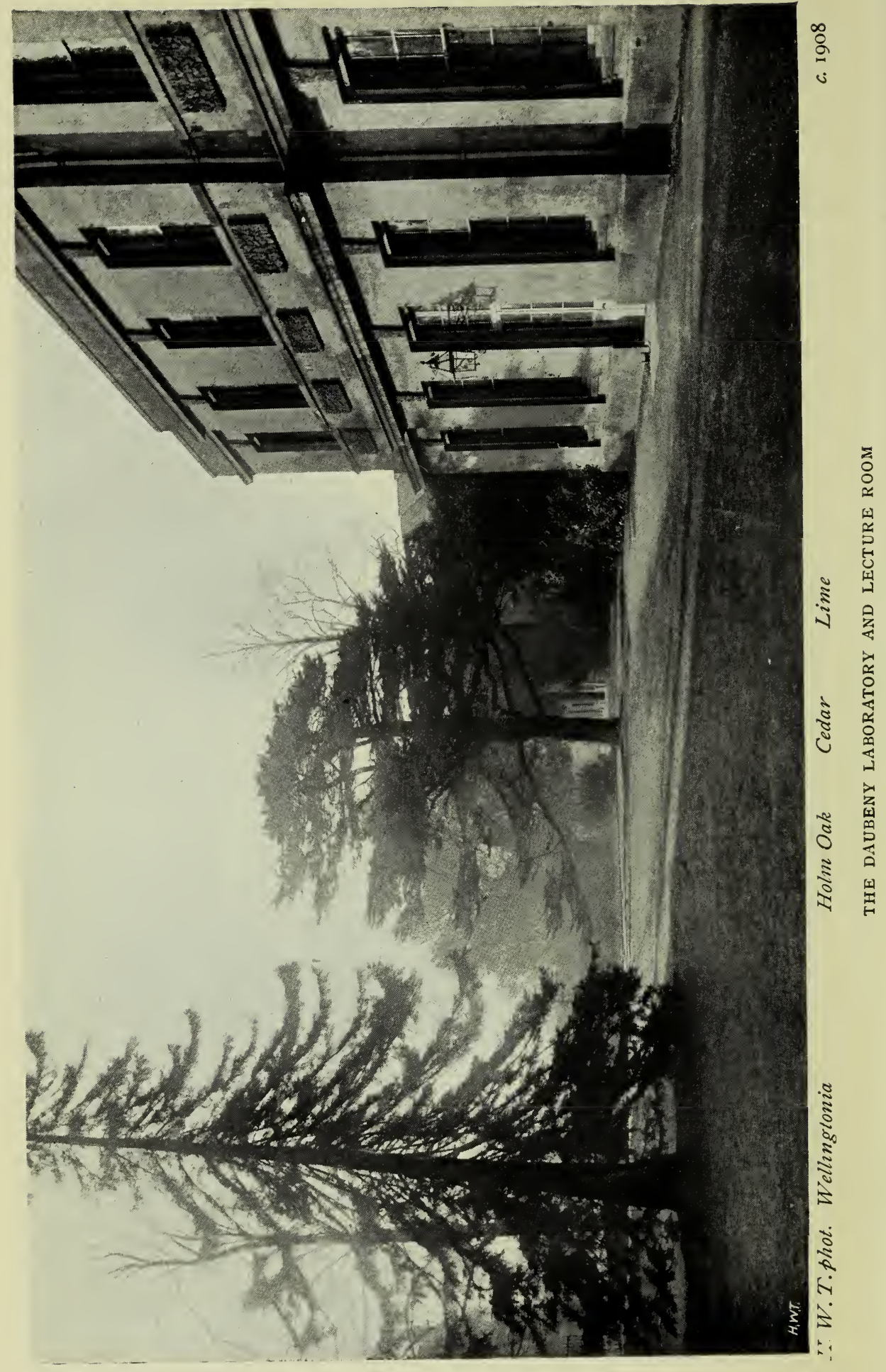




\section{THE TREES, SHRUBS, AND WALL PLANTS}

Par ses fruits, par ses fleurs, par son beau vêtement, L'arbre est de nos jardins le plus bel ornement:

Pour mieux plaire à nos yeux combien il prend de formes.

Delille, Les Jardins.

For detailed lists of the Wall Plants, see p. 144.

On the strip of land intervening between the Botanic Garden proper and High Street is a specimen of Wellingtonia, Sequoia gigantea, the tallest growing tree in the world, which, should it ever attain to its full height, would extend without a branch to the height of Magdalen Tower, and would then support a pyramid of branches, the topmost of which would reach to the dizzy height of three Towers one on top of the other! The girth of such a tree would be $90 \mathrm{ft}$.; our specimen measuring but $7 \mathrm{ft}$. I in. An American botanist has renamed this genus Washingtonia: there is no end to the confusion introduced into scientific nomenclature by the ignorance or jealousy of "scientists" over the water.

The Cedar of Lebanon, with a trunk girth of $8 \frac{1}{2} \mathrm{ft}$., was a fine-grown tree before the weight of the snowfall of April 25, 1908, when 18 in. of snow fell and brought down one limb: the building of Professor Vines' new Laboratory in I9II bringing down another. In 1836 it was already $3 \circ \mathrm{ft}$. high, with a trunk diameter of $\mathrm{r} \mathrm{ft} .3$ in., and a head diameter of $27 \mathrm{ft}$. One day, let us hope, its place will be adequately taken by the two young cedars near by; but the soil does 
Thuja menziesia

Juniperus sphaerica,

Lindl., N. China

Cornus tartaricus, var. Spathii

Juniperus chinensis, Lin., Tsuga canadensis, N.E. China

\section{America}

G

Berberis buxifolia, Magellan Region

Libocedrus decurrens, Cupressus lawsoniana, Torr., California Silver Queen

Thuja orientalis, Japan

Cupressus lawsoniana Cupressus sempervirens, viridistricta
Biota orientalis, var. compacta

Clerodendron trichotomum, Japan

Juniperus communis, Europe

Phillyrea villemoriana,
Asia Minor
Cupressus macnabiana,
California
Halesia hispida, Japan
Thuja orientalis, var. elegantissimum
Taxodium distichum N. America

Syringa

Laburnum vulgare, va quercifolium

$\mathbf{E}$

Euonymus latifolium

Philadelphus grandi florus

Pyrus intermedia Erh , Europe, $5^{\prime} 9^{\prime \prime}$
Robinia PSEUdACACIA

Prunus spectabilis, China

Corylus colurna, L., Himalaya $6 \mathrm{ft}$.

[Prunus cocomilia, Ten.]

Crataegus oxyacantha

\section{H}

Abies veitchii, Japan

Ilex aquifolium, Europe

Pinus monticola, Cali-

Gymnocladus

CANADENSIS, L.,

$\mathrm{N}$. America

Cupressus lawsoniana, California

Picea pungens

Pinus sylvestris Thuja

Chamaeocyparis obtusa, Japan, var. plumosa

Retinospora obtusa, Jap.
Aesculus flava

FOUN

Cupressus fastigiata

Fraxinus pubescens

N. America

$4^{\prime} 8^{\prime}$

Buxus balearica, S. Europe

Cladrastis tinctoria

Rafin., N. America

Chamaeocyparis pisifera, Japan, var. aurea

Aesculus RUBICUNda, Lon

Lodd., N. America $6 \mathrm{ft} .6 \mathrm{in}$.
Abies brachyphylla,

Japan

Cupressus lawsoniana, var. alumi

Pinus cembra, Europe

Lonicera albigena

Ailanthus GLANDulosa, Desf., China $6 \mathrm{ft} .3$ in.
ஸ் Diospyros virginiana, N. America $3 \mathrm{ft}$. Ace Viburnum prunifolium, L. , N. America

Ginkgo

Taxes baccata $\delta$, Europe 


\section{P L A N, I 9 I I}

\section{GATE}

EOPHORA JAPONICA

otoneaster nummularia,

N. Africa

piraeas

Cistus laurifolius

\section{$\mathbf{F}$}

Juniperus thurifera, S.W . Europe

Elaeagnus macrophyllus, Thunb., Japan

Chamaeocyparis obtusa, Japan, var. plumosa

Willows aurea

'yrus sorbus, Europe

$$
\text { Ostrya carpinifolia, S. Europe } 4^{\prime} 3^{\prime \prime}
$$

FRAXINUS ORNUS

$8 \mathrm{ft} .6 \mathrm{in}$.
Thuja

\section{China}

Cupressus nootkatensis, Pyrus germanica Lamb, Oregori, var. lutea

Calycanthus floridus, L., N. America

Prunus serotina, $\mathrm{N}$. America $3 \mathrm{ft} .6 \mathrm{in}$.

Thuja occidentalis, var. vervaeneana

Cistus cyprius

Chamaeocyparis filifera, Crataegus orientalis, Lejapan vant $2 \mathrm{ft} .9$ in.

Crataegus tanacetifolia, Levant 3 ft. 5 in.

Fagus sylvatica Picea excelsa, var. pyraASPLENIFOLIA $6^{\prime} 8^{\prime \prime}$ midalis

UERCUS maCrocarpa, Corylopsis spicata, Japan N. America $3 \mathrm{ft}$. 2 in. onicera xylostemum

Chamaeocyparis lawsoniana, var.

Birch 5 ft. 3 in. Podocarpus andina, Jap.

cer monspessulanum $5 \mathrm{ft} .6$ in.

Cupressus glauca, ปี China Pyrus maulei, Japan

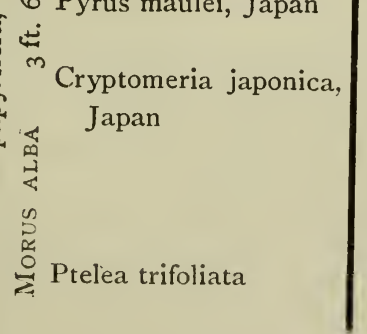

DIAL Pyrus sorbus, Europe Copper Beech

Taxus baccata, var. ele- Pyrus aria, Ehr., Eugantissima rope $4 \mathrm{ft}$.

Xanthoceras sorbifolia, CRATAEgt's oXYACANChina THA $4 \mathrm{ft} .4$ in.

Podocarpus japonica, Japan

Thuja plicata, N.W. Rhamnus catharticus, America Europe

\section{B}

Cupressus lawsoniana, Staphylea pinnata var. compacta

Halimodendron argen- Carpinus betulus $\quad 7 \mathrm{ft}$. teum, Asia

Taxus baccata, var. adpressa

$\pm \quad$ Pyrus malus
Pyrus communis Pinus Austriaca
$9 \mathrm{ft} .9 \mathrm{in}$. 3 ft. 9 in. 
not appear to suit well, and it will not be in our time that they will attain to the massive beauty of the old cedar.

Beyond the large Holm Oak, Quercus ilex, $8 \mathrm{ft}$. in girth, to the east, has been newly planted an Arbor vitae, Thuja occidentalis, interesting as the particular species of American tree which was the first to be cultivated in this country.

Near the Lime by the main entrance to the Garden is our largest Box-tree, with a stem of about $2 \mathrm{ft}$. in girth. Box-wood has been used to such an extent for making engraved blocks for the illustration of books and journals that the supply of large pieces in recent years has not kept pace with the demand. It will be interesting to see whether the substitution of photographic process-blocks for wood-cuts will give large box-trees a new lease of life.

\section{Plan of the Garden}

The plan of the Garden within the walls still retains its early simplicity. There is a walk along each of the four sides. Two main walks leading from the North to the South Gate and from the East to the West Gate cross one another by a circular fountain in the middle of the square garden. Two other walks from north to south divide the Garden into eight plots, which for ready reference are marked A to $\mathrm{H}$ upon the plan. These two walks may be termed the Dog Walk and the Boar Walk, after the sculptures which ornament them. The originals are in the Uffizi Gallery in Florence.

The arrangement of the trees is shown on the plan, $p p .36$ and 37. A list of wall-plants is printed on p. 144.

Trunk-girths are measured at a height of about $4 \mathrm{ft}$.

On entering the Garden by the Danby Gate the visitor cannot fail to notice the very fine Sophora japonica, close on $70 \mathrm{ft}$. in height, a species of Leguminous tree common in courtyards of Eastern temples, whose flowers yield a yellow 
dye; and the Deciduous Cypress, Taxodium distichum. These two trees grow in striking contrast to left and right of the middle path to the Fountain. The latter is an example of a cone-bearing plant which sheds its leaves in winter. It was planted about 1840 and is now $5 \mathrm{ft} .8 \mathrm{in}$. in girth; but in Mexico, its native land, it attains to a girth of trunk of $90 \mathrm{ft}$. and to a great age: "the identical tree at Chapultipec under which Montezuma was accustomed to sit previously to the conquest of Mexico is yet living, and known as the Cypress of Montezuma."

The Oxford Sophora, with its girth of $\mathrm{I} 3 \mathrm{ft}$., surpasses by a foot the taller specimen at Cambridge. It was planted by the elder Baxter about $\mathrm{I} 8 \mathrm{I} 7$, and it is still growing rapidly.

Immediately within the Danby Gate on the left, in a warm corner of the wall, is Christ's Thorn, Paliurus aculeatus, a native of the Mediterranean region. It was checked by the severe winter of $1837-8$, when the thermometer sank to $I^{\circ}$ Fahrenheit, but it recovered. It attracts especial attention because it is considered to be the plant from which the Crown of Thorns was made. It is certainly spinous enough, and is a common hedge-plant in the Holy Land, where, however, a large proportion of the flora also bear spines. It is covered in autumn with a profusion of small yellow flowers. Another claimant to the honour of the Crown is the Glastonbury Thorn.

Turning to the left, the visitor will find, in the northeastern corner, the Wild Black Cherry Bark, Prunus serotina, a medicinal tree of N. America, a Medlar, Pyrus germanica, and two Levantine Thorns; while against the East Wall grow specimens of Kerria japonica, of Smilax sarsaparilla from Florida, misnamed because it does not yield the drug after which Linnaeus named it, and of the Dutchman's Pipe, Aristolochia sipho, remarkable for its singularly formed flowers, which reach a larger size in a tropical species grown under glass on the other side of the wall. At intervals are planted Roses and Ivies (unnamed). In the bed are species of Ribes. 
In the gravel walk between the East Gate and the Fountain grows a magnificent specimen of the Service Tree, Pyrus sorbus, said to have been planted from the fruit of the Wyre Forest tree by Professor Sibthorp (1784-95) and now $50 \mathrm{ft}$. high, girth $5 \mathrm{ft} .4 \mathrm{in}$., the largest but one in this country, but, like the White Beam, Pyrus aria, near by, sadly overshadowed by the large Copper Beech (fig. p. 98), which, though the largest timber tree in the Garden, girth $12 \mathrm{ft}$. 6 in., is not worthy of the area it covers, and should be sawn back with unsparing hand. As in many other large examples of its kind, the copper colour is less well pronounced than in younger trees. A Beech of the purple variety may be seen in Wadham Garden.

The next tree is a specimen of the Glastonbury Thorn, Crataegus oxyacantha, the descendant of the famous thorn said to have grown from the walking-staff cut from the thorn used for crowning our Saviour, which Joseph of Arimathea stuck into the ground at Glastonbury, when it immediately put forth leaves and flowers! It sent out its blossoms on Christmas Day each year, refusing in 1733 to accommodate itself to the new style, and with conservative persistence blossomed on January 5. The original thorn was destroyed by Puritan fanatics-one of whom "was wel served for his blind zeale, who, going to cut doune an ancient white Hauthorne-tree, which, because she budded before others, might be an occasion of Superstition, had some of the prickles flew into his eye and made him Monocular" (James Howel, in "Dodona's Grove").

'The Common Buckthorn, Rhamnus catharticus, used formerly to be valued for its bluish-black berries which yield a nauseous and violent purge, and also the Sap Green pigment of painters. A preparation of the bark of an allied $N$. American species, $R$. purshiana, is used in medicine under the name of Cascara Sagrada. The leaves of our tree are highly appreciated by green fly and form a source of infection to other plants. 
The East Wall is largely

With ivy canopied, and interwove

With flaunting honeysuckle-MiLToN;

but we also notice a typical plant of the Moonseed, Menispermum canadense, with its large handsome foliage and horseshoe or crescent-shaped carpels, whence it takes its name. A.Wistaria sinensis has monopolised a large portion of the wall and forms a striking object in the spring, from the profusion and magnitude of its pendent clusters of blue papilionaceous flowers. Before the severe winter of r860 a Judas Tree, Cercis siliquastrum, flourished for thirty years against this wall. Its purplish-pink flowers generally appeared a month later than Easter, the proper date according to its fabulous reputation as the tree upon which Judas Iscariot hanged himself.

In the shrubbery on the right are the Hornbeam, Carpinus betulus, a tree indigenous to the chalk of Oxfordshire (Druce), Staphylea pinnata, the Apple, Pyrus malus, and a large Peartree; and in the south-east corner of the Garden a noteworthy Weeping Ash, with a perfect tangle of contorted branches which have actually grown into one another where they cross. This tree is no doubt a descendant of the original found near Wimpole in Cambridgeshire in the middle of the eighteenth century, which has been propagated by grafting on stems of the Common Ash.

Proceeding by the walk along the South Wall we notice an Austrian Pine, $9 \mathrm{ft}$. 9 in. in girth, and the North American Ptelea trifoliata standing at the south end of the Dog Walk, on either side of which have been planted elegant Japanese Conifers and interesting varieties of Yews, Cypresses, and other trees-but as several of these are likely to grow to a large size, they will have to be moved or herbaceous plots must be sacrificed.

Continuing along the South Walk in the shrubbery in 
Plot C may be seen the White Mulberry, Morus alba, which was introduced into Southern Europe from China about $154^{\circ}$ for food for silkworms, and, being less hardy than the common black species, is occasionally damaged by severe frost, an accident which befell our tree in the disastrous winter of 1860. In 1872 it had an arched opening right through its stem, a circumstance which was reported not to have affected its equanimity. It has since lost a large limb, of 18 in. in diameter. The earliest varieties are recommended for cultivation in this country as a means of obtaining home-made silk in favourable seasons.

The Paper Mulberry, Broussonettia papyrifera, a native of India and Japan, where it is made into paper, is also assiduously cultivated by the Pacific Islanders for making tapa, a kind of cloth which is much worn: to prepare this, the bark of the smaller branches is soaked in water, scraped with shells, beaten and squeezed together.

Beneath is the free-growing shrubby Poison Ivy, Rhus toxicodendron. Beware of it! For reasons, see p. 64 .

The two Yews, male and female, are the last vestiges of the double hedge before mentioned which extended across the Garden to the Danby Gate. In a garden where space is so valuable there would be much to be said in favour of restoring them to their ancient formal shape and of thus lessening their "massive shade." Indeed, in the oldest British Garden and in the former home of claśsical culture, we would gladly see some larger reminder of the Roman topiaria herba than the Box-edgings of the flower-beds. The Yews might be appropriately clipped to represent Adam and Eve.

Farther west are fine examples of a variety of the Box Elder or Ash-leaved Maple, Negundo aceroides, var. crispum, from N. America, and of the Tree of Heaven, Ailanthus glandulosa, a sort of gigantic Sumach with large pinnated leaves from China, beloved by silkworms of several sorts. It has been known to throw up suckers from the roots ạt 
a distance of $\mathrm{roo} \mathrm{ft}$. from the parent stem, and one of these at Oxford actually bore flowers.*

Just beyond is one of the most singular trees in the Garden. In the Maidenhair-tree, Ginkgo biloba, we have an example of a tree of the remote geological past living in the present. It has no near living relatives, but is the last survivor of an ancient family which has been traced back in fossils to the Primary Rocks. It might not have survived were it not for the fostering care of generations of Buddhist monks. So far as is known at present the Ginkgo is unknown in the wild state, only as a cultivated and sacred tree planted in the gardens of Chinese and Japanese Buddhist temples; and were it not for this the race might have become extinct. It has plum-like seeds like Cycads, and, like them, motile male cells. Ginkgos lived before insects, which have produced flowers in plants, appeared in the world. The trunk diameter of this tree was I ft. at I $\mathrm{ft}$. from the ground in $\mathrm{I} 838$ : now it is $4 \mathrm{ft}$. Io in. at $4 \mathrm{ft}$. About twenty years ago it looked as if it were going to die, but it is healthy enough now.

The Kentucky Coffee-tree, Gymnocladus canadensis, remarkable for the stumpy character of the young wood, which gives it in winter the appearance almost of a dead tree, was a donation from Mr. Rogers of Balliol College, November I 7, I 835. The wood has a value, and the fresh leaves macerated and sweetened are recommended as a poison for house-flies.

The climbers and wall plants against this side of the South Wall are those which do well with a north aspect; and here we notice a recently acquired collection of brambles including Rubus biflorus, ichangensis, deliciosus, lasiostylis, parkeri, flosculosus, henryi, and others.

The neat-growing Azara microphylla from Chili, and Cotoneaster horizontalis from China, on either side of the Mexican Choisya ternata, will be sure to attract attention. Two Sweet Bays, Laurus nobilis, sacred to priests, sacrifices, * Gard. Chron. 1887, ii. p. 364 . 
and victors in antiquity, flank the pillars of the South Gate, and a third specimen grows well against the warm West Wall. Their poisonous property is caused by the prussic acid in the leaves. The gilded leaves of this plant ought to be used at Queen's College at Christmas-time for decorating the boar's head, instead of those of Prunus laurocerasus.

The boar's head in hand bear I,

Bedecked with bays and rosemary.

West of the South Gate a Crataegus mexicana is dated I824; intermingled with the other plants are Roses and various species of Honeysuckle, Lonicera discolor, India ; fragrantissima, China ; periclymenum ; etrusca, Mediterranean: brachypoda, Japan.

In the south-west corner of the Garden a young Weeping Birch replaces the old tree which some will remember. Near by are Picea pungens and Pinus sylvestris, and in the shrubberies, Daphne mesereon and Berberis stenophyllum and Darwinii.

The most noteworthy trees and shrubs along the Western Walk, proceeding from south to north, are: Prunus cocomilia from Calabria, which has been suggested as yielding a good substitute for Peruvian bark, by Professor Tenore of Naples* ; and Corylus colurna from the Himalayas, which yields the Constantinople Hazel-nuts, or Turkey-nuts as they are frequently called.

In the corner of Plot $\mathrm{H}$ is the Locust-tree or False Acacia, Robinia pseud-acacia of N. America, which deserves to be more widely grown for the sake of its wood: it is very durable when in the ground, and makes excellent posts.

Lawson's Cypress is remarkable alike for its symmetry of form and for the exceeding variability among its seedlings. The variety here represented is viridistricta; but lutea, Silver

* The old tree, having reached the limit of its life, was taken down while this book was in the press, but others are coming on. 
Queen, aurea, alumi, compacta, may be seen by the sides of the Boar and Dog Walks. No plant occurs in more varieties: out of a batch of seedlings hardly any two will be alike.

The wall plants against the West Wall include a very fine male Garrya elliptica, from mountains not far from San Francisco, California, named in honour of a Hudson's Bay pioneer, which produces clusters of yellow catkins in the winter months; also the Fox Grape of N. America, Vitis riparia, to the south of the West Gate, formerly regarded as an unworthy representative of the cultivated Vine of the Old World, but since employed in certain of the Western States for wine-making; north of the Gate, Vitis corinthiaca, cultivated in Greece and the Levant for preparing dried currants, of which we are said to consume a million hundredweight per annum. They are in no sense related to our garden Currant (Ribes). That grapes used to ripen in Oxford, as elsewhere, in the Middle Ages, indicating warmer summers, is shown by the occasional mention of vineyards and uvae aestivales in old documents relating to the city, c. I 220-I300. Then follows Spiraea lindleyana, already a fine plant in 1853 ; Colletia spinosa of S. America, a remarkable member of the Rhamnaceae, in which the leafless stem is modified to form flat, spiny, triangular joints; not less remarkable is Ephedra distachya from the rocky shores of the Mediterranean, which is considered by many botanists to belong to the Coniferae.

In the corner by the Lecture Room is a fine Loquat, Photinia (Eriobotrya) japonica, a well-known Chinese dessert-fruit a little larger than a crab-apple, which unfortunately rarely fruits in the open in England. The garden ornament in the corner of the path is a copy of the celebrated Warwick Vase.

Against the Laboratory grow some sixteen varieties of Clematis, a Magnolia Yulan from China, and an aged Magnolia grandiflora, which, like the Fig-trees close by, 
was killed down to the roots in the winter of $1860-1$, but then put out again from the old wood.

Proceeding from the Danby gate along the central walk, we notice on the left the Quercifolium variety of the Common Laburnum, "dropping wells of fire" when in flower; Euonymus latifolium, and Philadelphus grandiflorus. On the right, under the Sophora, are Cotoneaster nummularia from N. Africa and a bed containing many interesting species of Spiraeae.g. thunbergii, as well as Lonicera pileata, Olearia haastii, and species of Cotoneaster.

In the centre of the Garden, grouped around the Fountain, will be found another specimen of the Service Tree, smaller than the giant under the Copper Beech.

Hop Hornbeam of Italy, Ostrya carpinifolia, girth $4 \mathrm{ft} .3$ in., remarkable for the scaly catkins of the fruit, resembling those of the hop. The mistletoe which grows on this tree so abundantly does not appear to do it much harm. The Manna Ash, Fraxinus ornus, is an old tree, grafted on the Common Ash, and may date from Sibthorp's time. It is a great ornament to the Garden in spring, for the profusion of its small diandrous flowers, which have an aminoid scent. The tree is interesting likewise as being the source of the manna of commerce, the children's laxative; incisions being made through the bark, from which the juice, which gradually hardens into this product, exudes. A Turkey Oak, Quercus cerris, standing on the left-hand side of the middle walk, was cut down, with the sanction of Magdalen College, a few years ago.

The Cut-leaved Beech, Fagus asplenifolia, $6 \mathrm{ft}$. 8 in. in girth, is always putting forth branches which bear leaves of the Common Beech, which, if not cut out, might in time, with their ruder vitality, entirely replace the more delicate leaves of this beautiful variety.

On the western side are the European Pyrus intermedia, arid a series of $\mathrm{N}$. American trees, including the Yellow and 


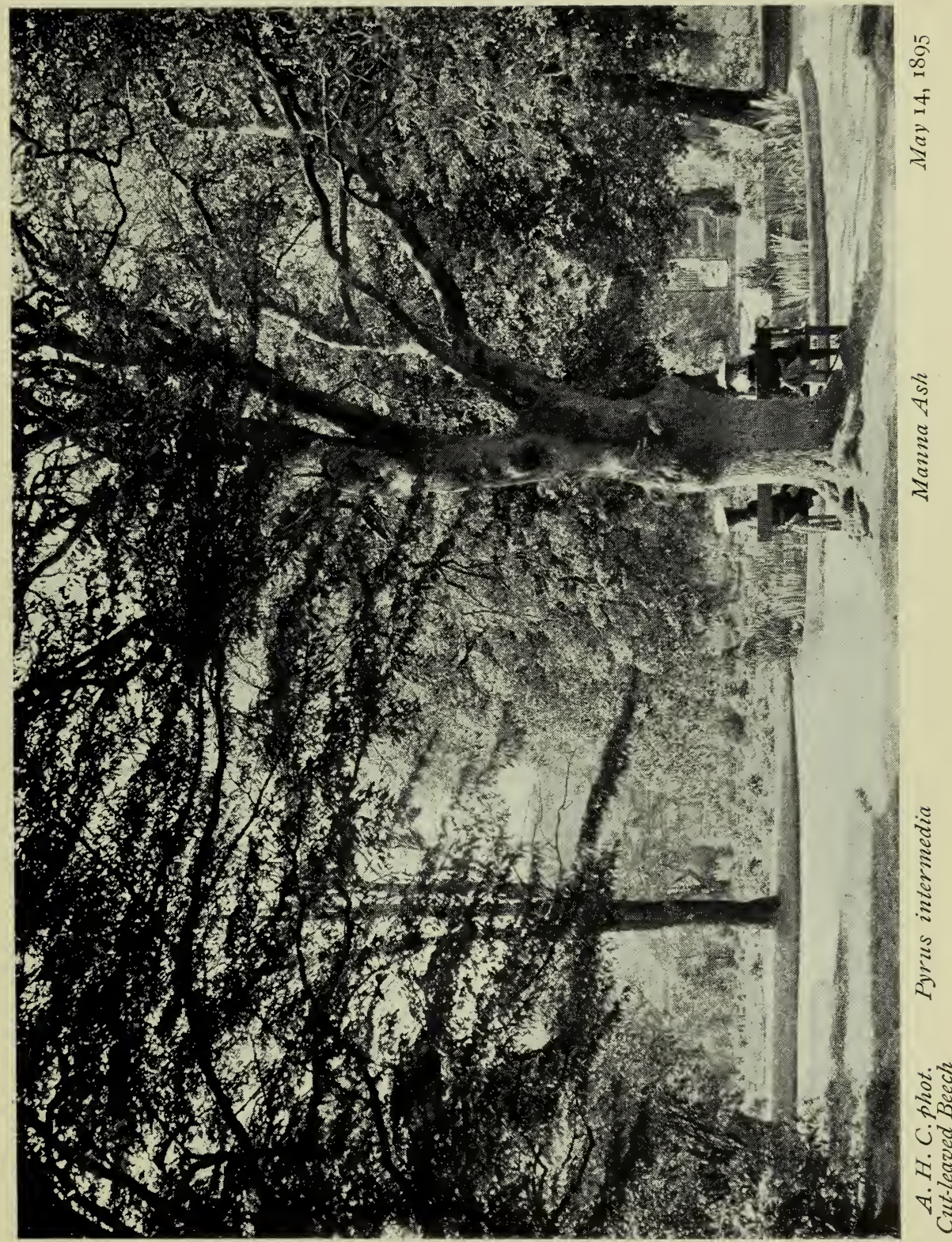



Red Horse-chestnuts, Aesculus flava and rubicunda, already old trees in 1850; the Red Ash, Fraxinus pubescens, known by its brown bark; the Yellow Wood, Cladrastis tinctoria, bearing fragrant white flowers in June and bright yellow leaves in autumn; the American Persimmon, Diospyros virginiana, which flowered in 1893 and set some fruit, but the fruit never came to perfection; and Viburnum prunifolium, a relation of the Wayfaring Tree of the South of England.

In the shrubbery are the beautiful Hibiscus roseum and two varieties of Prumus.

On the eastern side is a notable specimen of the $\mathrm{N}$. American Bur Oak, Quercus macrocarpa, trunk girth $3 \mathrm{ft} .2$ in., which is worthy of being more extensively planted in this country. Lonicera xylosteum almost fills a small bed under a Birch; and in the middle of a clump of shrubs is a goodsized Montpelier Maple, Acer monspessulanum, clothed in spring with pretty yellowish-green flowers.

Having now passed in review the more important trees and shrubs at present growing within the walls of Lord Danby's Garden, we may turn our attention to those without the walls.

\section{The Pinetum}

We do not know whether those who originally undertook the cultivation of the land outside the walls were influenced by the thought of the verse in the well-known chapter (xli.) of Isaiah :

I will plant in the wilderness the cedar . . .

I will set in the desert the fir tree, and the pine, and the box tree together;

but so it has come to pass.

Some sixty years ago a strip of ground outside the walls to the west of the Garden was rented by Dr. Daubeny from Magdalen College for growing Cone-bearing plants, but, although a start was made with a score of species, only some half- 
dozen still survive. Many of the others were killed during the severe winter $1860-\mathrm{I}$, when, after a long period of wet, the thermometer sank on the eve of Christmas Day to zero of Fahrenheit.*

The only trees remaining of the original collection include a Puzzle Monkey or Chili Pine, Araucaria imbricata, girth $2 \mathrm{ft} .7$ in., which has not fruited-the seeds of this species are eaten for dessert in Chili ; a finely-grown Yellow Cypress, Thujopsis borealis; the Bhotan Pine, Pinus excelsa, Himalaya, trunk girth $6 \mathrm{ft} .2$ in.; and a Corsican Pine, Pinus Laricio, girth $7 \mathrm{ft} .6 \mathrm{in}$., which lost its leader when young.

The Stone Pine died in 1860 , as did the Deodars, but the Atlantic Cedar, planted 1854 , and $8 \mathrm{ft} .7$ in. in girth, has survived.

The Wellingtonia and Cedrus libani near the entrance have already been mentioned. The deficiencies in the collection of Conifers have recently been filled in part by planting a number of young Cypresses, Thujas, Firs, and Pines (see p. 36) by the side of the Dog and Boar Walks within the Garden walls, but there land is far too valuable for the culture of any but the most compact forms, and the Garden Curators would do well to order the more rigorous observance of the suggestion quoted above.

On leaving the Garden by the wide gap in the walls at the north-east corner, the visitor will notice two species of Ceanothus trained against the outer face of the wall next Leland's variety of the well-known evergreen, Crataegus pyracantha.

The fine clump of Pampas Grass, Gynerium, is interesting as the type of the vegetation which overspreads the vast plains of S. America. The leaves are hard, wiry, and edged by sharp points or teeth, little less hard than the teeth of a file.

* Dr. Daubeny printed a list of Conifers killed in I860, as a postscript to the Supplement of his Garden GuIDE, p. 49. 



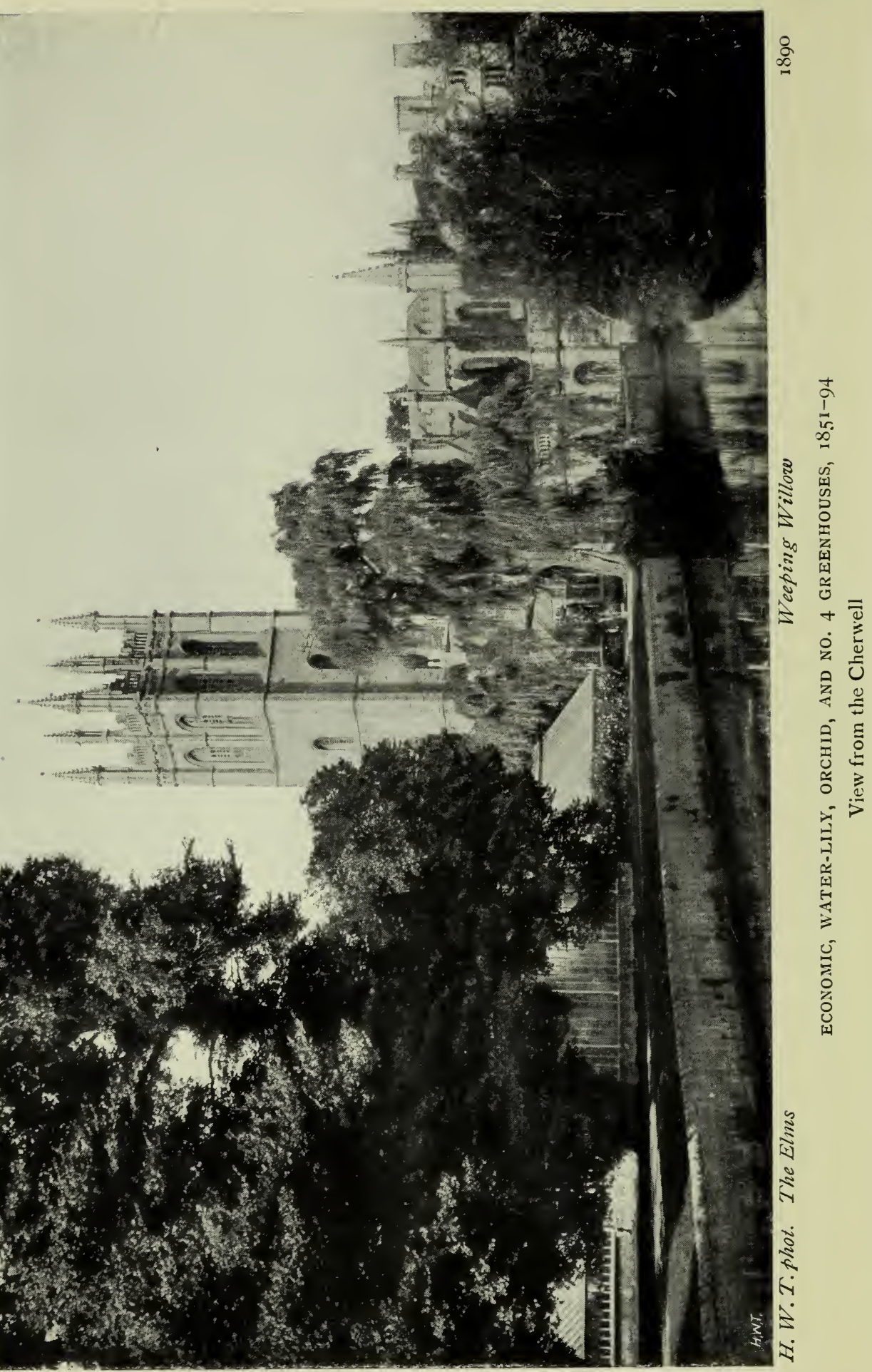


Near the river is a healthy young Crataegus grandiflora, which bears yellow fruit in autumn.

The stone vase near by, marks the spot where, until the storm of November I I, I89 I, a fine Weeping or Babylonian Willow, "Napoleon's Willow," used to overhang the Cherwell, and formed a familiar feature in pictorial views of the Garden and of Magdalen Bridge taken from that side. This Willow has, we are glad to say, been replaced by another specimen near the southern boundary. They grow quickly, for our old tree was said by Loudon to have been $30 \mathrm{ft}$. high in 1838 , after having been planted for twelve years.

A large specimen may be seen on the other side of the Cherwell in the garden of Magdalen College School, and there is part of a fine tree at Grandpont, but it is smothered in ivy. The term Babylonian is a misnomer, for the tree under which the Jews sat down and wept by the waters of the Euphrates was a Poplar with Willow-like leaves.

Salix babylonica is remarkable as being wholly propagated by slips. It is a dioecious plant, and the male has never yet found its way to Europe, so that every Willow of this kind, distributed over the country may possibly have been derived from the single cutting selected by the poet Pope from some rods in a package which came from Spain, and were planted in his garden at Twickenham.

Near the Cherwell was formerly the Willow Garden.

\title{
The Salicetum
}

\begin{abstract}
$\mathrm{Nec}$ vero terrae ferre omnes omnia possunt. Fluminibus salices, crassisque paludibus alni Nascuntur.-VIrGiL, "Georgics."
\end{abstract}

One of the less pleasing incidents in the history of the Garden was the dispersal and loss of the collection of Willows; and this paragraph is intended more as a suggestion to present and future Curators, and as a rebuke to certain of their predecessors, than as a guide to a "Willow Garden" which might, but which does not, exist.

The Willow is a tree of great economic value in the vicinity of 
our city, and, with care and knowledge, might become more so. In Scotland, for instance, osiers have yielded $£ 30$ an acre !

Within the last few years makers of cricket-bats have valued the wood of a particular kind of Willow so highly, that at a sale of Willow-trees on Sir Walter Gilbey's estate at Sawbridgeworth, in February, 1906, the best "Bat Willow" realised prices estimated to be equivalent to about "seven shillings per cubic foot," and " $£ 40$ has been offered for a single tree." * In Germany 48,000 acres of osiers are valued at $£ 396,000$ on the stocks, or at double when peeled, and they give employment to 40,000 people. Every seven years our water-walks, the banks of our streams, are made hideous by the Pollard.

Bordering upon the river, there existed from I825-40 a tolerably good collection of Willows, comprising, through the assiduity of Mr. Baxter and the kindness of Mr. Borrer, nearly a complete series of British species. Many of the smaller kinds were allowed to become overshadowed by the larger ones, and got lost, or were transferred to other parts of the Garden. Others were planted out in the University Parks, where their labels were mixed and their identity forgotten.

It is a pity, because both Mr. Borrer and his collection were unique. In the words of Sir W. J. Hooker: "No one has ever studied the willows, whether in a growing or a dried state, more deeply or with a less prejudiced mind."

'The dwarf species, Salix herbacea and $S$. reticulata, are worthy of a place in the bed in Herbaceous Plot F. The former in mountainous regions, as in the Alps, overspreads the slopes of the hills with a kind of herbage; each year two new shoots being put forth, which are covered over in winter by soil washed down from above by rains and torrents, so that the leaves alone appear above ground. Next year, however, each bud again puts forth a young shoot, and so the plant continues to extend itself, until from a comparatively few underground stems the whole surface of the ground is covered with a carpet of matted herbage. Hence it is called IVillow Grass.

At the present time the collection includes Salix alba var. vitellina, caprea, cinerea, fragilis, lanata, myrsinites, nigri-

* "Kew Bulletin," 1907. 
cans 9 , pentandra, triandra, phylicifolia, and the elegant rosmarinifolia, which always shows a tendency to revert to the ordinary variety.

Most species of Willow contain a glucoside called Salicin which possesses medicinal properties. From it, salicylate of sodium was originally prepared, though that drug is now made on a large scale from carbolic acid. It is used very largely for acute rheumatism, for which it is by far the most efficacious drug. Professor Daubeny remarked that it is a curious fact that swamps, which are a fruitful cause of ague and rheumatic disorders, favour also the growth of the very plants which are capable of counteracting them.

In the border between the Green-houses we have Hedysarum multijugum, which should be better known, and two exquisite Japanese Maples, Acer palmatum and the beautiful dark variety $A$. palmatum var. atropurpureum.

Near the Cherwell two large Elms grew to such a height as to completely overshadow the Glass-houses, and they had to be felled in 1893. Near by are three Limes, the largest $9 \mathrm{ft} .3$ in. in girth, and a clump of Dogwood, Cornus, prized by butchers for providing skewers for meat. The other trees in this quarter are a Willow with a girth of $\mathrm{I} 7 \mathrm{ft}$.- - greater than that of any other tree in the vicinity; two Horsechestnuts, the larger of which measures I4 ft.; a Black Walnut, Juglans nigra, $7 \mathrm{ft}$. 6 in.; and a variety of the Common Ash, Fraxinus excelsior var. parvifolia, $8 \mathrm{ft} .4 \mathrm{in}$. in girth. Just beyond the fence is a fine Poplar.

In the shrubbery near the southern pond are Sequoia gigantea, Cephalotaxus drupacea, Cupressus Lawsoniana, and Pinus pumilio. On the southern aspect of the South Wall the Pomegranate sometimes flowers freely (r893), but does not set fruit; but the fine Pyrus japonica yielded ro gallons of fruit in 1904 (Church's "Floral Mechanism"). Many fine climbers-for list, see p. I46-grow on the wall, Tamarix gallica and Parrottic persica being especially worthy of notice. 
A tree which should be in all Botanic Gardens is the graft-hybrid, Cytisus Laburmum adami, originally produced in 1826 at Vitry by inserting a bud of Cytisus purpureus on the stock of the Common Laburnum. We had a good tree in 1864 , but for the moment, the Garden has to rely upon the tree belonging to the Professor of Botany. There is another in the Banbury Road. Its peculiarity consists in its producing the yeilow flowers of the Common Laburnum indiscriminately intermingled with the purple flowers of $C$. purpureus on its branches. The inflorescences are either pure, like one or other of the parents, or may take their colour partly from one and partly from the other.

Having thus completed the tour of the Garden, the visitor may either leave by the wicket-gate into Rose Lane by Christ Church Meadow, or walk back by the Western Greenhouses, or return by the door in the South Wall to the Herbaceous beds.

What should I tell you more of it?

There was so many trees yet,

That I should all encombred bee

Ere I had reckoned every tree.-ChAucer. 


\section{THE HARDY HERBACEOUS PLANTS}

He therefore, who would see his flowers disposed Sightly and in just order, ...

Forecasts the future whole; that when the scene

Shall break into its preconceived display, Each for itself, and all as with one voice

Conspiring, may attest his bright design.-CowPER.

During the Professorship of Professor Daubeny the British Plants were disposed so as to illustrate the old artificial arrangement of Linnaeus, which was still resorted to as a dictionary, even by those who rejected it as a system, for this arrangement afforded a convenient method of determining the name of a plant, although often conveying no insight into its real structure and relations.

The beds before 1848 were all laid out in parallel rows, but Baxter transformed them into the many-shaped, rounded plots which are shown in detail in the map in the earlier editions of this book.

In 1884 Professor Balfour found part of the collection arranged according to the Linnean system, another portion according to the Natural system, annuals were displayed by themselves, and there was a separate collection of typical genera. In rearranging the plants for study, Professor Balfour threw the whole collection into one natural arrangement, following Bentham and Hooker's "Genera Plantarum" as the guide.

British Plants were indicated by having their names written in white on black tallies. 
The present scheme of the Herbaceous Beds is as follows :

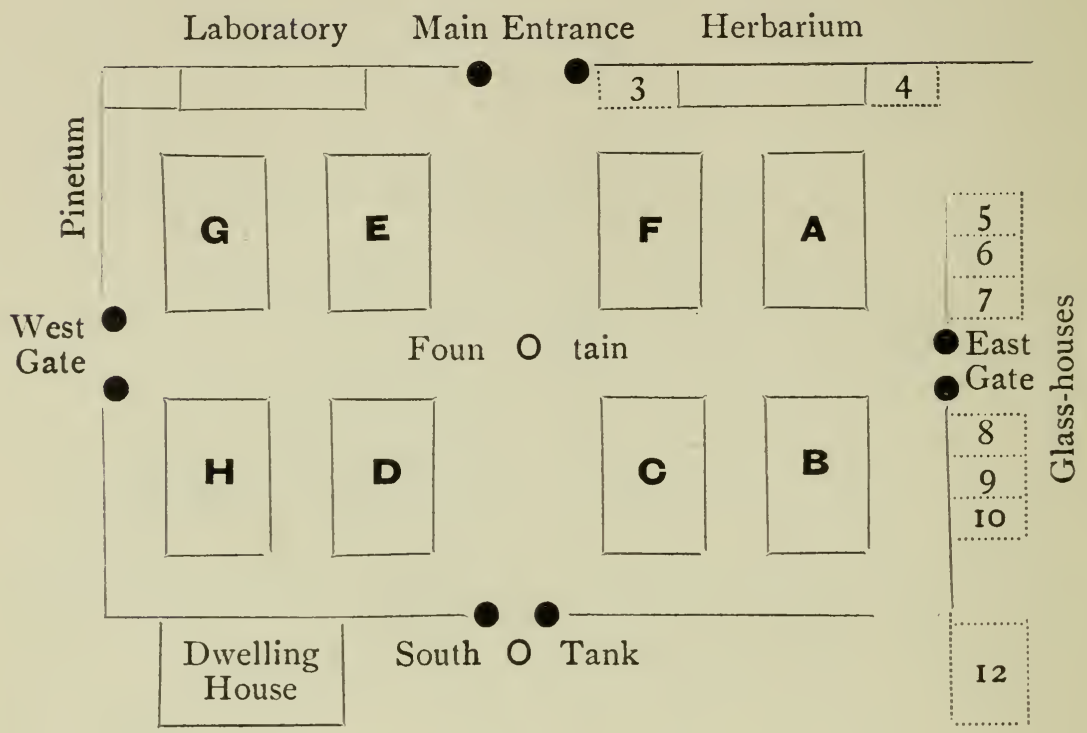

Of the eight plots into which the main walks divide the Garden, the Polypetalae occupy A, B, C ; the Gamopetalae, $\mathbf{D}, \mathbf{E}$; the Apetalae, F; and the Monocotyledons, $\mathbf{G}, \mathbf{H}$. There is no doubt that from a purely horticultural point of view, the practice of retaining herbaceous plants year after year in the same beds -is bad for many species. The soil gets exhausted, and in a state of nature, the plant would spread to pastures new. But this collection is primarily a teaching collection, and for the student there is great value in retaining plants in their relative systematic positions. A sickly plant can always be moved for a change to the rich and regenerative earth of the southern herbaceous borders-or be sent for a holiday to another garden. Even tutorial plants benefit by an occasional change: perhaps they like to get away from their Latin names. 


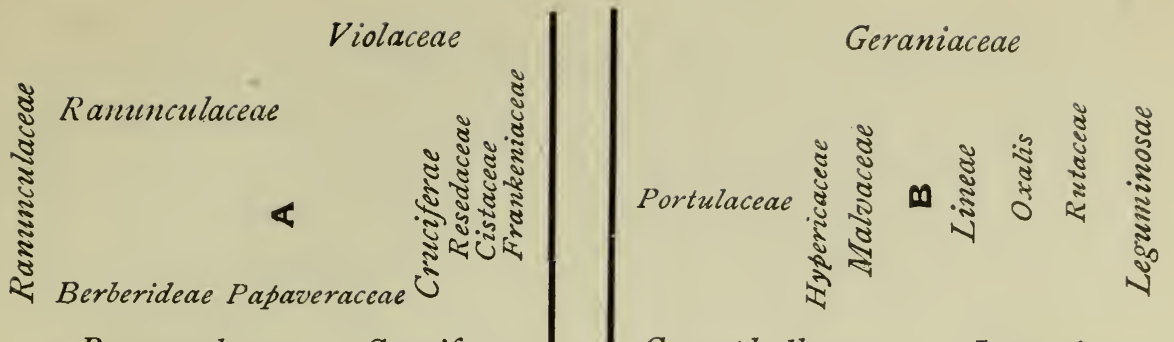
Ranunculaceae Cruciferae

Caryophyllaceae Leguminosae
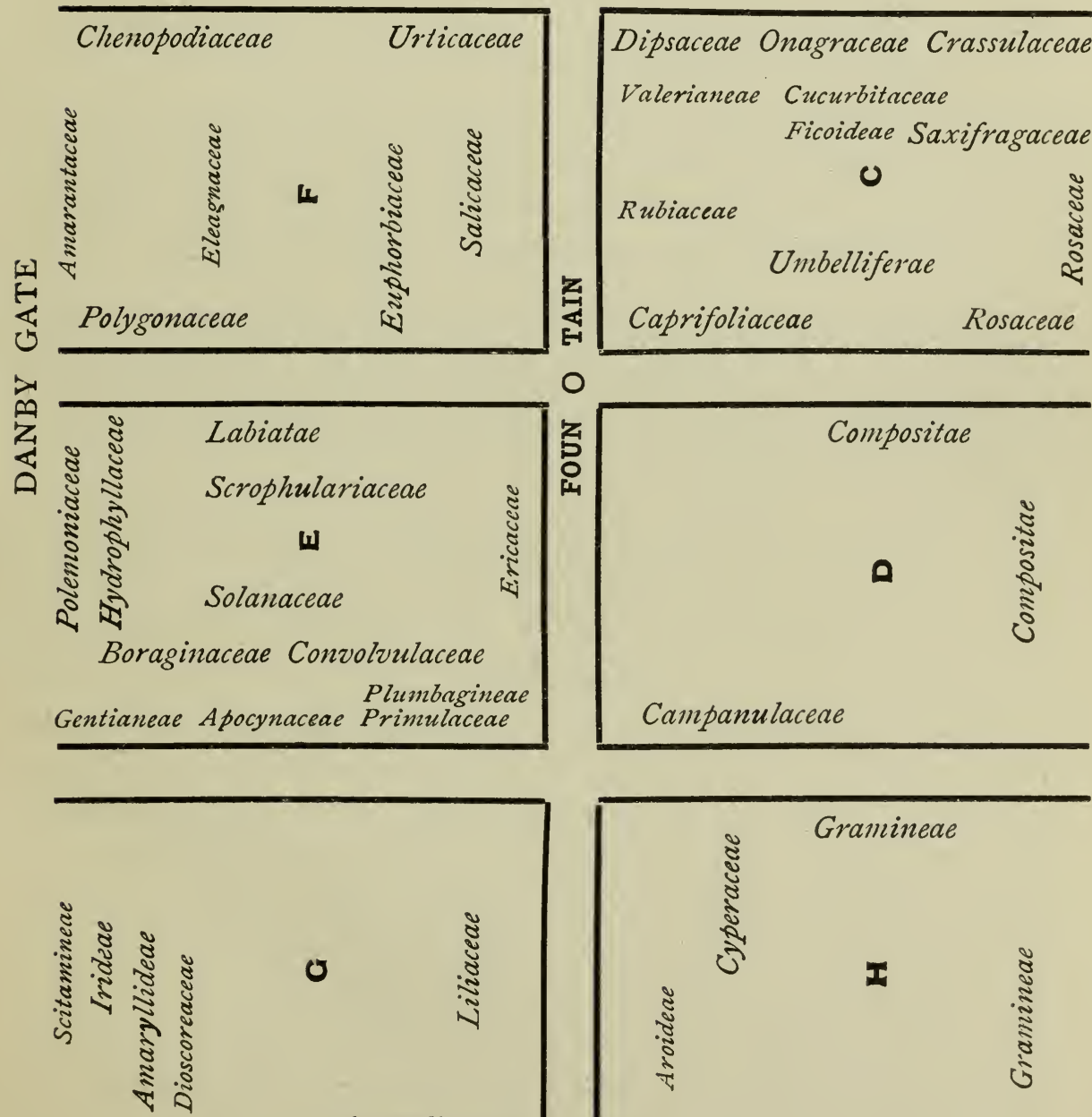

0

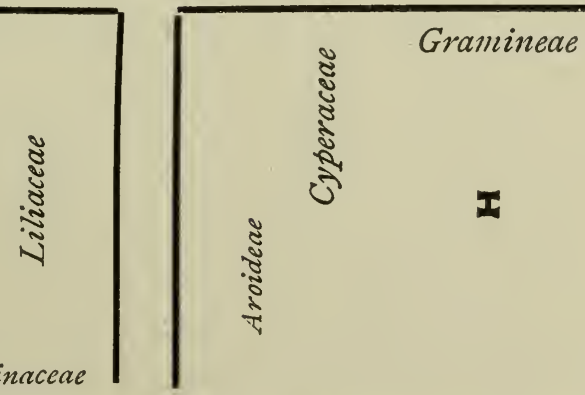

$\frac{8}{8}$

Commelinaceae

Key to the Natural Orders in the Herbaceous Beds 


\section{Explanatory Note}

In the following enumeration of the Natural Orders of Plants, the arrangement adopted being that of Durand's Index to the Genera Plantarum (1888), the numerals of the orders do not alzeays correspond with those written on the labels in the beds.

Brief notes on Natural Orders of large or tropical plants which are not represented in the Herbaceous Beds are also included for the sake of reference, but are printed in smaller type: further mention of many of these species will be found in the other chapters. Consult the Index.

It is of course impossible to guarantee that all species named in this GuIDE will always remain on view in the Garden, or even in the positions to which we have assigned them. To the best of our knowledge they have been, or ought to be, there.

The Natural Arrangement of the Herbaceous Plants in accordance with their supposed natural affinities commences in the north-east corner of the Garden near a Prunus serotina from N. America, with the

\section{POLYPETALAE}

\section{PLOT A}

\section{RANALES}

Ord. I. Ranunculaceae, or Crowfoot Family, is noted for the deadly poisons and powerful medicines yielded by its members. Five tribes are represented. To the first belong the familiar creepers or climbers of the genus Clematis, of which some beautiful hybrid varieties have been recently planted against the Laboratory (cf. p. I44). Old Man's Beard, $C$. vitalba, is the only British plant which may give a faint idea of the tangle of lianas in a tropical forest. A large specimen grows near the southern pond. In the corner bed are several species of Meadow Rue, Thalictrum, $T$. delavayi being among those which have been grown, and others of the 
Anemone Tribe, including the early-flowering Hepatica. Two beds under the Buckthorn in Plot B are devoted to Anemone appennina and to $A$. nemorosa robinsoniana.

Tribe iii. The Ranunculeae, or Crowfoots proper, include the Buttercup, $R$. acris, and Celandine, $R$. ficaria. The latter is noteworthy because it resembles Mono-cotyledonous rather than Di-cotyledonous plants in having closed bundles without a cambium, and in having only one cotyledon. The Double Ranunculus, so much cultivated in gardens, are varieties of $R$. asiaticus. $R$. nyssanus from Nyassa is a novelty.

Tribe iv. The Hellebores include many garden favourites, some of which are as poisonous as they are popular. Under the name of roots of Christmas Roses, Helleborus niger, from S.E. Europe, a drastic purgative and diuretic medicine, used to be largely imported from Hamburg. It is, however, more likely that the tubers are those of $H$. orientale or $H$. officinalis, which Sibthorp recognised as the Black Hellebore of the Greeks. Before the Christian era Melampus used it in the treatment of madness. Near Oxford, cattle have died from eating $H$. viridis (M.T.M.). Columbines, Aquilegia, Larkspurs, Delphinium, and Monkshoods, Aconitum, are much cultivated for their decorative value; but $D$. Staphisagria and $A$. Napellus are best placed beyond the reach of the ignorant on account of the virulent alkaloids they contain. Aconite tuber is distinguished from Horse-radish root by being shorter, turnip-like, tapering, dark coloured, and with many side rootlets.

The fifth tribe comprise the Paeonies. P. mlokosewitschi, obovata, wittmanniana, and Sunbeam $\times$ are among the more recent additions to the Garden.

Ord. 2. Dilleniaceae, a tropical order named after Dillenius, our Professor.

Ord. 3. Calycanthaceae. Carolina allspice, Calycanthus Aoridus, forms a bush on the western side of the plot. The bark is used in the United States as a substitute for cinnamon. 
Ord. 4. Magnoliaceae. Being woody trees and shrubs are not represented in the Herbaceous Beds. Two species are growing against the Laboratory wall. The bark of Drimys winteri was used by Capt. Winter, who commanded the "Elizabeth" under Sir Francis Drake in I579, "as a spice and medicine for scurvy" on his return voyage from the Straits of Magellan. The Tulip-tree, Liriodendron, is of this order.

Ord. 5. Anonaceae, Custard Apples, tropical trees and shrubs. Nutmeg, Monodora, is in the Palm House.

Ord. 6. Menispermaceae. The Moon-seeds are tropical climbing shrubs, but $M$. canadense grows against the East Wall. Cocculus indicus is used as a poison for fish.

Ord. 7. Berberideae. A bed in the middle is reserved for the smaller Barberries, but the larger species, Berberis stenophyllum, Darwinii, etc., must be looked for in the shrubberies in Plots D and H. The roots of the May Apple, Podophyllum peltatum, supply the valuable liver medicine, podophyllin. $P$. versipelle and $P$. emodi are grown in the Garden. The Epimediums are Alpine herbs.

Ord. 8. Nymphaeaceae. The Water-lilies will be found in the south tank and in the tank in No. 6 Green-house.

\section{PARIETALES}

Ord. 9. Sarraceniaceae, sometimes in No. 12 Green-house.

Ord. ro. Papaveraceae. The Opium Poppy, Papaver somniferum, yields a narcotic oil which when dried is sold as opium, which as a medicine may be reckoned "amongst the greatest blessings to mankind, but by its misuse, the greatest curse." We in Oxford should remember that it was at Worcester College just over a century ago that the brilliant author of the "Confessions of an Opium Eater" first had resort to the drug to allay pain. It has been calculated that $£ 20,000,000$ worth is annually consumed by mankind.

Ord. i i. Fumariaceae. The Fumitory Family include the delicate British species of the genera Fumaria and Corydalis (C. cheilanthifolia, thalictrifolia, wilsoni annuals), and the larger Dicentra spectabilis of N. America, a most beautiful herb. 
Ord. I 2. Cruciferae. The Cross-petalled family is a very large one, and, unlike those already described, contains no poisonous species. Many are of great value to mankind as food, on account of the nitrogenous substances they contain, as, for example, Mustard, Cress, Radish, Cabbage, Cauliflower, Broccoli, Turnip. Representatives of the following tribes will be found in the south-west beds of Plot A :

i. Arabideae. Stocks, Wallflowers, and Rockets. Cheiranthus mutabilis.

ii. Sisymbrieae. Hedge-mustard, S. officinale. London Rocket, S. irio, was so called because it sprang up abundantly over London after the Great Fire of I666. It comes up yearly in the Botanic Garden from self-sown seed (Druce's "Flora of Berkshire").

iii. Brassiceae, or Cabbages, Turnips, Colza, and Mustards. By repeated removal of the lower leaves, the stem of the Jersey variety of the Common Cabbage can be grown long enough for the manufacture of walking-sticks.

iv. Alyssineae. Horse-radish, Cochlearia armoracia. Scurvy Grass, C.officinalis, had completely established itself on the rockwork near the south pond in 1853 . v. Antony Wood records that in 1659 "scurvy-grass drink began to be drunk in the mornings as physick drink." Honesty, Lunaria biennis.

vi. Lepidineae, including that common weed, the Shepherd's Purse, Capsella Bursa Pastoris.

vii. Thlaspideae. Candy tufts, Iberis, and Penny Cress. viii. Isatideae. Woad, Isatis tinctoria, the skin-stain of the ancient Britons, is still cultivated in the Fens near Wisbech for using with "indigo." The literature of the dye manufacture has been collected by Dr. Plowright.

ix. Cakilineae. Sea-kale, Crambe.

x. Raphaneae. Radish, $R$. sativus. 
Ord. 13. Capparidean are allied to the Cruciferae. Capers are the flower-buds of Capparis spinosa common in S. Europe.

In the opposite corner, destroyed by the shade of the large Copper Beech, are beds containing:

Ord. I4. Resedaceae. The Mignonettes. The stems of the Dyer's M. or Yellow IVeed, R. Luteola, yields a yellow dye which has a good reputation for fastness. The Sweet M. of gardens, $M$. odorata, is said to be a native of Egypt.

Ord. I5. Cistaceae. Rock Roses are better represented in other parts of the Garden than here. The Gum Cistus, C. polymorphus, in hot weather exudes a glutinous gum with a strong scent. Labdanum, as this resin is called, "is the $\Lambda \hat{\eta} \delta o \nu$ of Dioscorides, in whose time the gum was obtained by driving goats among the shrubs, when the substance adhered to their fleeces and beards." The Cretans now collect it by raking with a "ladanisterion."

Ord. I6. VIOLACEAE.

\section{And there is pansies \\ That's for thoughts.*}

The roots of several of the Violets, e.g. of the Dog Violet, $V$. canina, are used medicinally as emetic and purgative.

$$
\text { POL YGALINAE }
$$

Ord. 19. PítTosporaceae. Australian shrubs.

Ord. 2r. Polygalaceae. Milkworts. Polygala is the only European genus.

\section{CARYOPHYLLINAE}

Ord. 23. Frankeniaceae. F. laevis, the Sea Heath, occurs in salt marshes from Yarmouth to Sussex. The order is related to the Tamaricaceae.

To the south-east of a sundial, mounted upon a basaltic

* Pansy = persée, "by which name they became known to the Brabanders and those of the Low Countries that are next adjoining."--Gerard. 
column* brought from the Giant's Causeway by Dr. Daubeny, is

\section{PLOT B}

Ord. 24. Caryophyllaceae or Chickweeds. In two long beds near the sundial may be seen the Pink Tribe, including Dianthus, Saponaria, Silene, and Lychnis. Dried roots of the Soapwort, Saponaria officinalis, like the Indian Sapindus, raise a lather in water, and so may be used as a substitute for soap. $G$. arrostii and other species of Gypsophila are used for washing silks in Italy and Asia Minor.

To the Alsinean Tribe belong the Sandworts, Arenaria; Starworts, Stellaria; Spurry, Spergula, and many other genera of small herbs.

Ord. 25. Portulaceae. The Purslane, Portulaca oleracea, is the type of a group of herbs and shrubs which live in dry places at the Cape and in S. America. The many coloured varieties of $P$. grandiflora make a grand show when grown in a border fully exposed to the sun.

Ord. 26. Tamaricaceae. Shrubs and trees with bitter bark from S. Europe and Asia.

Tamarix gallica flourishes against the South Wall of the Garden.$$
\text { GUTTIFERALES }
$$

Ord. 28. Hypericaceae. Tutsans or St. John's Worts.

Ord. 29. Guttiferae, or Gamboge Family, includes many exotics of worth, e.g. the Mangosteen and Mammee Apple, and Garcinia and Calophyllum, with oil-yielding seeds.

Ord. 30. Ternstroemiaceae. Tea Family. Camellia thea.

Ord. 31. Dipterocarpeae. The Wood-Oil Trees of the Oriental Region.

\section{MALVALES}

Ord. 33. Malvaceae. The Mallows are a large family, represented by comparatively few species in temperate climes,

* The recent pointing has covered the crystalline angles, and is a good example of destructive "restoration." 
but developing into shrubs and small trees of great worth in warm countries. The tropical genus Hibiscus supplies dyes, thickening for soups, flavouring for coffee, and rope. Gossyfium produces a fibre surrounding its seeds, known as cotton. We import about a million tons of the raw material every year, and another half a million tons of cotton-oil for making soap and feeding cattle.

The Hollyhock, Althaea rosea, is a conspicuous feature in Indian gardens, and was formerly so in England; but after 1873 the plants were attacked by the Hollyhock disease, caused by a fungus, Puccinia, and the species ran a risk of being exterminated. Sulphur-dusting is the best remedy.

Closely related orders are

Ord. 34. Sterculiaceae. The Chocolate-tree, Theobroma cacao, is growing in one of the stove-houses.

Ord. 35. Tiliaceae. Forest trees. Three Limes on the bank of the Cherwell : eight along the High Street.

\section{GERANIALES}

Ord. 36. Lineae. Flax, Limum usitatissimum, will be found in a small round bed near the middle of the plot, next to the Mallows. Our imports of the seed of this useful plant amount to close on 2,000,000 quarters per annum. After the linseedoil has been squeezed out, "oil-cake," the well-known cattlefood, remains.

The tribe Erythroxyleae are exotics. Erythroxylon coca in one of the Green-houses.

Ord. 38. Malpighiaceae are one of the families which, by their ropelike stems (lianes), contribute to the tangle of S. American forests. Galphimia glauca in the Stove-house.

Ord. 39. ZyGophyllaceae. Guaiacum is a West Indian genus.

Ord. 40. Geraniaceae. The Crane's-bills fill the southeast bed of the plot.

Tribe Oxalideae. The Wood-sorrel, Oxalis acetosella, is stated to be the original of the Irish Shamrock, but owing to the fact that it is not available as early as St. Patrick's Day, a 
leguminous plant, Medicago lupulina, is worn instead in Dublin (see "Ulster Journal of Archaeology," v. pp. I 2-20). The emblem has often been stated to be represented by Trifolium repens. The pleasant acid taste is due to acid potassium oxalate, once a flavouring for Oxford beer. .

Tribe Balsamineae. The Touch-me-not, Impatiens nolime-tangere, and other species have explosive fruits which, when ripe, open at a touch.

Ord. 40a. Included among the Geraniaceae by some botanists are the Tropaeolaceae, commonly, though wrongly, named Nasturtiums, which were introduced into our gardens from Peru in I686. Tropaeolum majus is the classical instance of a flower round which has been seen a "lightninglike phosphorescence" on a sultry summer evening.

Ord. 4I. Rutaceae, or Rues, are well known to herbalists on account of their essential oil, and their antispasmodic, febrifuge, and tonic properties. Common Rue is Ruta graveolens, and Dittany, Dictamnus fraxinella, which on a still, dry, warm summer evening emits an inflammable vapour which can be kindled with a match without injury to the flowers, as originally described by the daughter of Linnaeus in $\mathrm{I} 762$, and as Mr. Hatchett Jackson has shown me in the gardens of Keble College. Related and sometimes included in this order is the

Order of Aurantiaceae, Oranges and Lemons. The largest is the Shaddock, Citrus decumana, in No. I2 Green-house.

Ord. 42. Simarubeae. The Quassias are noted for their intense bitterness. They are represented in the Garden by the "Tree of Heaven," Ailanthus glandulosa, in Plot D.

Ord. 43. Ochnaceae. Lophira alata yields "Meni" oil and "African Oak" wood.

Ord. 44. Burseraceae. The Myrrh Family is noted for its yield of balsams, frankincense, and myrrh. Hedzwegia boswelli is resin-bearing.

Ord. 45. Meliaceae. An order of tropical trees and shrubs, including the Indian Neem-tree, Melia azadirachta; the Central American Mahogany, Stvietenia mahagoni; "Cedar" wood from India and Australia, Cedrela toona; Satin wood from Ceylon, Chloroxylon swietenia. 
Ord. 47. Olacineae are tropical trees and climbers. Coula, Ximenic.

Ord. 48. Ilicineae. Holly, Ilex Aquifolium. The wood is used largely by fretworkers and carvers. The juice of Holly bark, boiled and mixed with nut-oil, yields Bird-lime.

Ord. 50. Celastrineae. The Spindle Trees. Euonymus europaeus is indigenous in Oxfordshire. $E$. latifolia grows in the central walk. Cath $a$ and Elaeodendron are under glass.

Ord. 53. Rhamnaceae, or Buckthorn Family, are trees and shrubs represented in various parts of the Garden by Zizyphus, Paliurus (p. 39), Rhamnus (p. 40), Ceanothus (p. 48), and Colletia on the West Wall.

Ord. 54. Ampelidaceae. Two species of Vines may be seen against the West I'all, and are described on p. 45. Ampelopsis quinquefolia, introduced from N. America in 1629, about the time of the foundation of the Garden, is the familiar Virginia Creeper, an old specimen of which is trained against the Library. In the Stove-house, an allied tribe is represented by Leea micholitzi.

\section{SAPINDALES}

Ord. 55. Sapindaceae. The Soapworts.

Ord. 56. Hippocastanaceae. Horse-chestnuts (p. 47).

Ord. 57. Aceraceae. Maples and Sycamores, Acer, Negundo (p. 42).

Ord. 59. STAPHYLEACEAE.

Ord. 6r. Anacardiaceae. Cashew-nuts. Members of this order grow to a large size in the tropics. The genus Rhus, which grows in S. Europe, yields the Sumach dye, $R$. coriaria; Japanese lacquer, $R$. vernicifera; a tanning principal, $R$. glabra of N. America. Mere contact with $R$. toxicodendron, the Poison Tree, may give rise to "violent inflammation, followed by blisters and ulcers." One of these poisonous shrubs grows near the Mulberry in Plot.C. It is wise not to handle the leaves ; indeed, Dr. Church has informed me that an American once wrote to an Oxford journal to protest against the plants being left unguarded! Kaln states that the allied $R$. radicans gives out a poisonous exhalation to which certain women are very susceptible, even though they do not approach the plant nearer than a yard.

Pistacia vera, fruit-kernels, are much used by confectioners ; $P$. lentiscus yields the Greek resin "Mastic."

The fruit of the Mango, Mangifera indica, if of the right variety, is among the most delicious of tropical fruits.

Ord. 63. MORINGEaE. Horse-radish-tree, Moringa pterygosperma.

Ord. 64. Connaraceae. Tropical climbers.

Ord. 65. LeguminosaE. The four southernmost beds in 

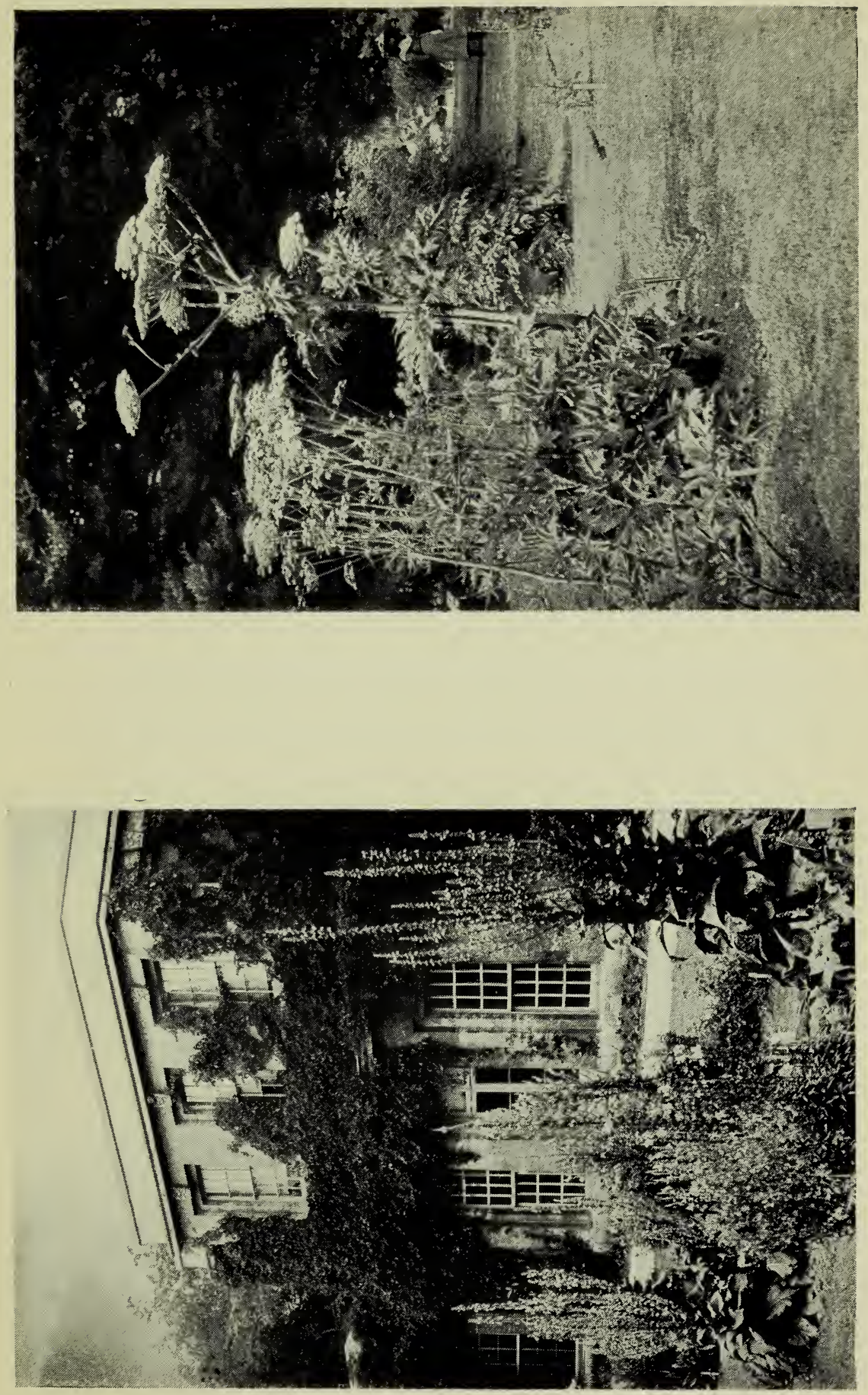

the plot, alongside the shrubbery, grow plants of one of the largest of the Natural Orders, which are characterised by the shape of their fruit, known to botanists as a legume or pod, by the butterfly-like shape of their flowers, and by the fact that they alone of all plants live in happy association with fungi which they house in swellings on their roots, and which in return supply the plants with nitrogenous food, partly prepared from the nitrogen of the air. The plant is thus able to flourish in poor and exhausted soils. Included under this head are :

Sub-ord. I. Papilionaceae.

Tribe i. Sophoreae. Represented in the Garden by the trees of Sophora japonica (Plot F) and Cladrastis (Plot D). ii. Podalyrieae. Baptisia tinctoria is the wild Indigoroot of the United States.

iii. Genisteae. Cytisus, Gorse, and Lupins.

An extraordinary graft-hybrid of Cytisus laburnum receives special notice on p. 52 .

iv. Trefoils and Clovers.

v. Loteae. Bird's-foot Trefoil.

vi. Galegeae. The Indigo-plant of India, Indigofera tinctoria. The False Acacia, Robinia pseudacacia, is growing in Plot $\mathrm{H}$ : it is a common tree in Oxford gardens.

vii. Hedysareae. Sainfoin, Onobrychis sativa; Telegraph plant, Desmodium gyrans.

viii. Vicieae. The Bean, Vicia faba; Pea, Pisum sativum; Sweet Pea, Lathyrus; Lentil, Lens esculenta ; Lathyrus sibthorpii.

ix. Phaseoleae. Runner Beans. P. multiflorus is the Scarlet Runner Bean. Wistaria chinensis grows to a large size on the western aspect of both East and West Walls. Calabar Bean, Physostigma.

x. Dalbergieae. Dalbergia latifolia yields the Rosewood of S. India, and Pterocarpus species supply many other valuable coloured woods well known in the Oriental region. 
Sub-ord. II. Caesalpinieae. Species of Cassia, Bauhinia, Tamarindus, Ceratonia, the Carob, and Cercis will all be found in the Greenhouses ; the Kentucky Coffee-tree, Gymnocladus, in Plot D.

Sub-ord. III. Mrmoseae. The Sensitive Plant, Miniosa pudica (p. II6); Acacias (pp. 96, I I 7).

\section{PLOT C}

At the southern end are the

Ord. 66. Rosaceae. Owing to the large size of many of the Rose Family they must be sought elsewhere than in the Herbaceous Beds devoted to the Natural Orders.

i. 'The Roseae, or Roses proper, are best seen in the beds nearest Christ Church Meadows and on the walls of the Garden. Rosa laevigata, var. anemonaeflora, $R$. sepium, $R$. pisocarpa, and $R$. sericea, var. pteracantha.

ii. The smaller-growing Spiraeas are planted in the southernmost bed of this plot, but larger species will be found in the shrubberies, especially in Plot F, next the Sophora-e.g. S. aitchisonii, S. henryi. The giant S. kamschatkensis forms a striking contrast to the cut-leaved $S$. aruncus, var. kneiffii. S. lindleyana is trained against the West Wall. Varieties of Kerria japonica may be seen against the East and South Walls.

iii. To the Plum tribe belong the Cherry, Prunus cerasus, and the Almond, $P$. amygdalus, outside the West Wall. The evergreen Cherry Laurel, P. laurocerasus, and Portural Laurel, $P$. lusitanica, will be found in the shrubberies. The first specimen of the latter grown in this country was received here from Portugal in 1648 . When cut down in 1826 it was $25 \mathrm{ft}$. to $30 \mathrm{ft}$. in height, with a trunk $2 \mathrm{ft}$. in diameter at $\mathrm{I} \mathrm{ft}$. from the ground.

iv. The Poterieae include Agrimonia, Alchemilla.

v. Potentilleae. Strawberry, Fragaria. A small bed is devoted to dwarf-growing $\mathrm{Brambles}$, but a larger collection of recent acquisition has been trained 
against the South Wall (north aspect). The Blackberry is Rubus fruticosus; Raspberry, R. idaeus.

Dr. Daubeny had two Raspberry-plants growing in the Garden, reared from seeds said to have been found within the skeleton of a man contained in a Dorsetshire barrow, and therefore supposed to be contemporaneous with the period of the ancient Britons! We cannot believe in such vitality.

vi. Pomeae. Trees. Cotoneaster, C.augustifolia, pannosa; Crataegus, C. holmesiana; Pear, Pyrus communis; Apple, P. malus; Service Tree, $P$. domestica; White Beam, $P$. aria (p. 40).

Ord. 67. Saxifragaceae include the Gooseberry and Currant Sub-order. The bulk of the collection of Saxifrages is potted among the Alpine Plants near the south fountain. Recent additions are the very fine varieties of Saxifraga aizoon, Dr. Ramsey, rosea, and scardica.

Heuchera; Grass of Parnassus, Parnassia palustris.

To this order belong the Hydrangeas; Mock Orange or Syringa, Philadelphus; Deutzia, D. lemoinei; Currants and Gooseberries, Ribes, and similar flowering shrubs.

Ord. 67a. Cephalotaceae comprise but one Australian species, Cephalotus follicularis (p. III).

Ord. 68. Crassulaceae. The House-leeks and Stonecrops are known by their fleshy leaves, which are arranged in regular spirals so beautifully depicted by Dr. Church in his scholarly dissertation on Phyllotaxis. Cotyledon, Sedum, and Sempervivum are British. A selection of Crassulas, Echeverias, Kalanchoë, and other exotic forms may be studied in the Cactus House. In many we may study how a compact structure, due to the suppression of the internodes, has been produced by desiccation.

Ord. 69. Droseraceae. Sundews.

Ord. 70. Hamamelidaceae. Witch Hazels. The Iron-tree, Parrotia persica, was introduced in 1848 ; the Witch Hazel, H. virginica, is one of a group of N. American shrubs. Liquidambar orientalis yields the perfume Liquid Storax. L. styraciflua is the American Sweet Gum-tree. 
Ord. 72. Halorageae. Mare's-tails, Hippuris vulgaris; Gunnera scabra, from Chili, has handsome foliage. It is unfortunately not quite hardy.

\section{MYRTALES}

Ord. 73. RHIzOphoreat. Mangroves of muddy estuaries in the tropics.

Ord. 74. Combretaceae. Myrobalans of India.

Ord. 75. Myrtaceae. The Myrtle, M. communis, is the European representative of an order which includes the Blue Gums, Eucalyptus, of Australia, certain species of which supply the Karri and Jarrah woodpaving blocks; Brazil-nuts, Bertholletia excelsa; Cloves, Guavas, and Punica granatum, of which a specimen is trained against the South Wall, where it occasionally flowers.

Ord. 77. Lythraceae. To the Loosestrife Family belongs Lazesonia inermis of Egypt, which supplies Oriental ladies with the henna which fashion dictates as necessary for dyeing their finger-nails.

Ord. 78. OnagraceaE. Including the Clarkias and many other beautiful garden plants, such as the Evening Primroses, Oenothera; Willow Herbs, Epilobium; Enchanter's Nightshade, Circaea lutetiana; and to these are related the Fuchsia of S. America. Oenothera lamarckiana is the classical instance of a plant in a "mutable state," i.e. a plant from the seeds of which new species are being produced per saltum at the present time (de Vries, "Theory of Mutation").

\section{PASSIFLORALES}

Ord. 79. Samydaceae.

Ord. 80. Loaseae. Blumenbachia hieronymi.

Ord. 8i. TuRneraceae.

Ord. 82. Passifloraceae. Passion Flowers, from Asia and tropical America, ripen fruit out of doors in warm seasons-e.g. at Folly Bridge, I9II. (See Green-houses, p. 99.)

The Papayaceae are a tribe of Passifloraceae.

Ord. 83. Cucurbitaceae. Gourds are for the most part tropical plants; Bryony, Bryonia dioica, being the only species 
indigenous in England. Many varieties of Cucumbers, Melons, and Pumpkins are of very ancient cultivation in the East, and are unknown in the wild state.

Ord. 84. Begoniaceak. None of the Elephant's Ears are hardy, but several ornamental varieties are usually bedded out for the summer months: this year in Plot $\mathrm{H}$.

\section{FICOIDALES}

Ord. 86. Cactaceae are grown in Cactus House No. Io.

Ord. 87. Ficoideae. The Fig Marigolds must not be confused with the true Figs. Most of the genera are S. African, but the Ice-plant, Mesembryanthemum crystallinum, is well known in S. Europe.

\section{UMBELLALES}

Ord. 88. Umbelliferae are more particularly abundant in the Mediterranean lands. Some are esculent, but many, and especially those living in damp places, are poisonous, or at least powerfully medicinal.

The tall-growing Heracleums will at once attract attention to their bed in the middle of the plot. Some species are very attractive to bumble-bees, which fall to the ground drugged and dizzy as the result of their visit. A close relation is the familiar Parsley, Pastinaca oleracea. Condemned criminals in ancient Greece were commonly poisoned by Hemlock, Conium maculatum, and it was thus that Socrates died. The swollen stems of Fennel, Ferula communis, are eaten like Celery in S. Europe. It has been identified with the Náp $\theta \eta \xi$ of Dioscorides, and is still called Nartheca by the Greeks. "The hollow of the stem is occupied by pith, which, being well dried, takes fire like a match,* without injuring the outer portion; and the stem is therefore much used for carrying fire from place to place. Our sailors laid in a store of it. 'This custom is of the highest antiquity, and may explain a passage in 'Hesiod,' where,

* i.e. a slow match for firing gunpowder. 
speaking of the fire that Prometheus stole from heaven, he says that he brought it in a Ferula, - the fact being, probably, that Prometheus invented the steel that strikes fire from flint, and used the pith of the Ferula for a match, teaching men how to preserve fire in these stalks" (TOURNEForT).

Narthex assafoetida yields the drug in the form of tears of gum-resin in Persia.

To this order belong the Samphire, Crithmum; the Carrot, Daucus; the Caraway, Carum carui, and many other familiar plants.

Ord. 89. Araliaceae. Several unnamed Ivies climb upon the walls* of the Garden, but Aralia racemosa, from N. America, will be found in the Herbaceous Beds. The pith of the exotic, A. papyrifera, cut into small sheets, is the rice-paper of the Chinese.

Ord. 90. Cornaceae. Aucubas will be found in the shrubberies. The wood of Cornus mas is used for making butchers' skewers.

\section{GAMOPETALAE}

At the northern end of Plot $\mathrm{C}$ will be found plants belonging to the epigynous gamopetallous division.

Ord. 9I. CapRIfoliackae, comprising the Elder and Honeysuckle Tribes, are mostly shrubs of considerable growth. A large Guelder Rose, Viburnum, may be seen in Plot D. Adoxa moschatellina and Linnaeus' favourite plant, Linnaea borealis, are elegant dwarf representatives of the two tribes. The branches of the "twisted eglantine" of Milton, Lonicera, have been thought to exhibit a "perceptive power," because young shoots meeting a branch of another plant twine from right to left; whereas if they meet one another they twine in different directions, one to right, the other to left, thus forming a strong combination. A more

* The Ivy on the Danby Gate was removed in 1900 at the request of the Curators of the University Chest " in order that the state of preservation might be ascertained.". (Cf. p. 210.) 
recent explanation may of course be found in Darwin's book on "Climbing Plants."

Ord. 92. RUBIACEAE include three groups of plants, two of which (I) the Coffee-trees, and (2) Cinchonas, yielding quinine, including Bouvardia, are exotic; but the third or Stellate tribe is represented in temperate climes by the Bedstraws, Galium; Madder, Rubia tinctoria ; Woodruff, Asperula odorata; and the common Field Madder, bearing the name of the founder of our chair of Botany, Sherardia arvensis.

Ord. 93. VALERIANACEAE are remarkable for the wonderful psychological effects they have upon cats, both large and small. A small sprig thrown into a lion's cage will cause him to roll upon it in a great state of excitement. Centranthus ruber is naturalised upon many a Cornish wall and elsewhere in England (cf. p. I33).

Ord. 94. Dipsaceae. Dried Teazles, flower-heads of Dipsacus fullonum, are used for fulling cloth. Several species of Scabious are cultivated in flower-gardens.

\section{PLOT D}

In beds shaded on the east by a row of $\mathrm{N}$. American trees, we find

Ord. 96. Compositae. The most numerous family of all the flowering plants and world-wide in distribution. Eleven tribes are distinguished.

i. Eupatorieae, represented in England by Hemp Agrimony, E. cannabinum, have local reputations of being able to cure most diseases, including cholera and snake-bite.

ii. Asteroideae. The Daisies grow near the southwest corner. North of these are the

iii. Senecionideae. The Groundsel, S. vulgaris, belongs here, as does the Oxford Ragwort, S. squalidus, common on our old walls, and introduced perhaps from Sicily to the Botanic Garden, whence it has 
spread over the city and now over the Great Western Railway system (Druce). Doronicum; Petasites; Tussilago. The Japanese Coltsfoot, $T$. japonica, is a fine ornamental plant.

iv. Anthemideae. From Wormwood, Artemisia absinthium, an infusion can be prepared which is a good domestic tonic, and was formerly in favour as an anthelmintic. Chrysanthemum; Yarrow, Achillea; Camomile, Anthemis; Tansy, Tanacetum. v. Helianthoideae. The Sunflowers fill a long curved bed, together with the Rudbeckias, Zinnias, and Coreopsis. The well-known Jerusalem Artichoke, Helianthus tuberosus, came from N. America. It was introduced into the Farnese Garden at Rome in 1617 , whence it was distributed in Europe under the name of Girasole or Sun Flower-a name that is commonly corrupted into "Jerusalem."

vi. Helenioideae. Gaillardia and Tagetes.

vii. Inuloideae. Elecampane, I. helenium, is one of our rarer local plants. It occurs near Eynsham.

viii. Cynareae. Thistles. The Carline Thistle is hygrometric-open in drought, closed in rain. Charlemagne used the root of $C$. acaulis as a remedy for plague in his army.

A fine Knapweed, Centaurea ragusina, was brought home from the Mediterranean by Sibthorp about 1790, and was first introduced to horticulture as a bedding-plant by Baxter, who used it exterisively in the Oxford Garden.

ix. Calenduleae. Dimorphothecn.

x. Mutisieae. S. American climbers.

xi. Cichorieae occupy the north-east bed near the Fountain. Relatives both of the Dandelion, Taraxacum officinale, and the Lettuce, Lactuca sativa, will be found here. On the walls of the Garden Hieracium amplexicaule has become naturalised. 
The north-west bed of Plot D is filled with the

Ord. 99. Lobeliaceae. Indian Tobacco, L. inflata, is used medicinally for asthma. And the

Ord. ioo. Campanulaceae. Harebells. The Harebell, $C$. rotundifolia; Canterbury Bell, $C$. medium. A noteworthy member of the group, Ozestrozeskia magnifica, is worthy of a place in the Garden.

\section{PLOT E \\ ERICALES}

Ord. I02. Ericaceae. To the Heath Family belong the beautiful "American Plants"-the Rhododendrons, Azaleas, and Kalmias. None do well in our calcareous Oxford soil, but a few specimen plants are contained in a small round bed under a Pyrus intermedia at the south end of the plot. Heaths are examples of moorland plants which live with a microscopic partner, to the friendship of whom they are indebted for certain foods present in the peaty soil, though in a form which is not available to the unaided Heath. The useful partner is a fungus, known to science as Mycorhiza. In this country they are represented by the dwarf-growing Bilberries, Cowberries, and Cranberries of the genus Vaccinium. The Arbutus, abundant about the lakes of Killarney, has been killed in severe winters in Oxford, but there is a plant that bears fruit at the Canal Offices (A. H. C.). In Australia, Epacris replaces the Erica of the Northern Hemisphere.

Ord. I07. Plumbaginaceae. Sea Lavender, Statice. In the Sea Pink or Thrift, Armeria, minute glands in the axils of the leaves rid the plant of effete or injurious substances. When they are watered with water containing lime, specks of chalk may be seen at the mouths of the glands. Plumbago europaea has a bad reputation on the Continent: beggars use it to ulcerate the skin, and thus to elicit alms from the compassionate.

Ord, iọ. Primulackae are less remarkable for economịc 
than for aesthetic qualities. To the genera Primula, Cyclamen, Soldanella, Androsace, Dodecatheon, belong some of our most lovely "Alpine Plants," and many will be found in the pots round the South Tank. Here the order is represented by Lysimachia and genera of larger growth. The Poor Man's Weather Glass, Anagallis arvensis, was so-called because the closing of its flowers was supposed to indicate an approaching shower.

Ord. i Io. Sapotaceae. Tropical Sapodillas. Palaquium gutta is a source of true guttapercha.

Ord. in. Ebenaceae. A Persimmon, Diospyros virginiana, grows in Plot D.

Ord.. I12. StYRACeaE are Oriental trees and shrubs yielding balsamic gums. The Snowdrop Tree, Halesia tetraptera, should be more widely grown.

Ord. I 13. Oleaceae. Shrubs and trees, such as the Privet, Ligustrum vulgare; Olive, Olea europaea; Ash, Fraxinus; Lilac, Syringa vulgaris ; Forsythia; Jasminum.

Ord. II4. Salvadoraceae. Mustard-trees, are all exotics.

In the western beds are

Ord. I I5. Apocynaceae. Many of the N. American Dogbanes possess strong medicinal properties, whence the name. Apocynum androsaemifolium is remarkable for its stamens, which contract violently on the slightest irritation, such as the insertion of a hair or the proboscis of a fly. It thus entraps flies in great numbers, and Burnet "has often seen from 50 to 100 flies imprisoned and slain, and, as it were, hung in fetters, in terrorem, by a single plant during the sunshine of a summer's day."

The Periwinkles, Vinca major and minor, belong here. Nerium oleander, Allamanda, and Dipladenia will be found in the Green-houses.

Ord. in6. Asclepiadaceae. Several species of Asclepias are grown in gardens. Here we have $A$. syriaca and incarnata and also Cynanchum acutum.

Stapelia, Hoya carnosa, and Ceropegia will be found under glass.

Ord. II7. LOGANIACEAE are extremely poisonous. Strychnos nux 
vomica and $S$. toxifera yield strychnine and the celebrated Wourali poison used for arrows by the Guiana natives. Buddleia albiflora, colvilei, and variabilis are shrubby herbs of recent introduction, but $B$. globosa is still one of the best. The genus was formerly regarded as Scrophularine.

Along the north end of the plot are

Ord. I 8 . Gentianeat. A bitter tonic is prepared from the root of $G$. lutea.

Ord. i i 9. Polemoniaceae include Jacob's Ladder, Polemonium coeruleum, Phlox, and the useful green-house climber, Cobaea scandens.

Ord. 120. Hydrophyllaceae, including Nemophila and Eutoca, have divided leaves and fruits technically described as capsules.

Ord. I 2 I. BoraginaceaE include the Forget-me-nots, Myosotis ; Comfrey, Symphytum; Hound's-tongue, Cynoglossum; Lungwort, Pulmonaria; and the green-house plant, Heliotropium peruvianum.

Ord. I 22. Convolvulaceae, or Bindweeds, are well-known climbing plants which, in the case of the members of the genus Cuscuta, the Dodders, have twined themselves into such close relations with their support as to have become wholly parasitic upon it. Cuscuta trifolii is very injurious to clover.

The Sweet Potatoes of tropical America are the roots of Ipomoea Batatas. I. learii flowered in June in the open border in 1842 .

Ord. I23. SolanaceaE. The Nightshades are mostly harmful -

Foxglove and nightshade side by side-

Emblems of punishment and of pride (SСOTT);

but, on the other hand, Lycopersicum esculentum, the 'Tomato, and Solanum tulierosum, the Potato, go far to redeem the good character of the order. The Deadly Nightshade, Atropa belladonna, and Henbane, Hyoscyamus niger, yield the wellknown alkaloids of the same name. The Thorn Apple, Datura stramonium, belongs to a second section of the order, 
It is an Indian herb containing a poison like atropine, which, when prepared from $D$. metel, is used by Thugs to stupefy their victims, and also by Mahommedans in the concoction of hashisch. To the third, the Cestreae, belong Nicotiana, the Tobacco genus, and Petunia, a well-known bedding plant. Salpiglossis, Schizanthus, and Browallic are grouped in the fourth tribe.

Ord. i24. Scrophulariaceae. The Great Mullein, Verbascum thapsus, is one of the finest of our roadside weeds, and it ranges from Aberdeen to the Himalayas. The Snapdragon, Antirrhinum; Toadflax, Linaria; Monkey-flower or Musk, Mimulus; and the green-house Calceolarias and Pentstemons have peculiar characters of their own, which take a tree-form in the Japanese Paulozenia imperialis.

To another section of the order belong the Foxglove, Digitalis; the Speedwell, Veronica; Eyebright, Euphrasia; and a plant which we hope will never be absent from the Oxford Garden-Sibthorpia from the south-west of England.

Ord. I25. OROBANCHACEAE. The Broomrapes, being parasitic upon other plants, have lost their green colouring matter. Lathraea squamaria has been said to set subterranean traps for catching insectś, but this is a myth.

Ord. 126. J.entibulariaceae include the carnivorous Pinguicula and Utricularia. Our Oxford Bladderwort, U. vulgaris, grows in Wolvercote ponds and S. Hincksey ditches, and was first noticed to digest young fish by Mr. G. Simms (G. C. D.).

Ord. 128. Gesneraceae include the showy exotic genera Gloxinia, Achimenes, and Streptocarpus, which are well represented in the Glasshouses. Ramondia from S. Europe is hardy.

Ord. I29. Bignoniaceae include the tree Catalpa from N. America, and the climbers Bignonia, Tecoma, and Eccremocarpus from Chili ; but none of the latter are thoroughly hardy with us.

In the south-east corner is a bed containing

Ord. I3I. Acanthaceae. In the beds is a clump of Bear's Breech, Acanthus mollis, the decorative leaves of which are believed to have suggested the beautiful Corinthian capital in architecture. Under glass are species of Thunbergia, Ruellia, and Justicia. 
Next is a small bed containing the

Ord. I 34. Verbenaceae, or Vervains - an order to which the Indian Teak-tree, Tectona grandis, also belongs.

Ord. i35. LABIATAE are a very numerous family widely distributed. Many contain reservoirs so well filled with aromatic volatile oils that they find great favour both in kitchen and boudoir.

"Here's flowers for you :

Hot lavender, mints, savory, marjoram."

Shakespeare, "Winter's Tale."

A mere list makes pleasant reading: Lavender, Lavandula vera; Patchouli and Sweet Basil; Spearmint, Peppermint, and Pennyroyal are species of Mentha; Hyssop, Balm, Rosemary, Sweet Marjoram, and Thyme are all Labiates.

A small bed near the Acanthus is reserved for the Catmints and Ground Ivies, Nepeteae, and another for the fine Ajuga genevensis in the curve of the Stachydeae, including the Dead Nettles, Lamium; Woundworts, Stachys; Horehound, Marrubium, and others. The Jerusalem Sage, Phlomis fruticosa, growing in a bed near the Library, makes a fine show in June with its yellow flowers, which prove so attractive to a certain class of visitors to the Garden that they steal the name-labels! The down of some of the species has been used for wicks, hence the name, from $\phi \lambda o \gamma \mu$ ós, a flame.

"There is $\mathrm{y}^{\mathrm{e}}$ wormwood sage Called Mountaigne sage, its to all appearance like Comon sage only of yellower green, a narrow long Leafe full of ribbs; In yo ${ }^{r}$ Mouth the flavour is strong of Wormwood to the taste" (Celia Fiennes, circ. 1695).

Ord. i36. Plantaginaceae. The common weeds termed Plantains are in a bed near the Taxodium. They are best killed when in a lawn by ammonium sulphate, sold impure under the name of "lawn sand." In olden days the flat leaves were used as vulneraries.

The plantain ribbed, that heals the reaper's wound.

SHENSTONE. 


\section{MONOCHLAMYDEAE}

\section{PLOT F}

In the north-west corner under the magnificent Sophora japonica are

Ord. i37. Nyctagineae, represented by a clump of the Marvel of Peru, Mirabilis jalapa-not the true Jalap. Tricycla and Bougainvillea are under glass.

Ord. I38. Illecebraceae are all tiny herbs; Corrigiola, Herniaria, and Scleranthus are English.

Ord. I39. Amarantaceae. Prince's Feather, Love-liesbleeding, Amaranthus, and Cock's-comb, Celosia, are common garden plants.

Ord. I40. Chenopodiaceae. The Goosefoot Family include many familiar esculents. The Mangold, Beta vulgaris; Red Beetroot, B. rubra; Saltwort and Marsh Samphire, Salsola and Salicornia; Sea Blite or Suaeda, containing sodium carbonate, are all common salt-marsh plants. Most of the Goosefoots, Chenopodium, are weeds, but Spinacia oleracea is cultivated as Spinach. Kochia scoparia trichophylla is a plant of great neatness which should be far more cultivated as a bedding-plant. During the year it changes colour from a bright green to vivid red.

Ord. I4 I. Phytolaccaceae. The berries of the Pokeweed, $P$. decandra, from N. America are used for staining wine.

Ord. I43. Polygonaceae. The Buckwheats, Docks, and Rhubarbs are often large-leaved plants of rapid growth, with small flowers, which, like those of the Lauraceae, have been variously interpreted by botanists, some considering that they are "monochlamydeous" without petals, which is the view indicated by their present position in the Garden; others holding that the petalloid whorl has been reduced or disguised. The larger Buckwheats, Polygonum cuspidatum and viviparum, take up much room, and frequently stray into their neigh- 
bours' beds. The largest of all is $P$. sachalinense; Rumex is the Dock and Sorrel genus; Oxyria, the Mountain Sorrel; Rheum officinale, Medicinal Rhubarb, a Chinese plant; R. rhaponticum, Garden Rhubarb.

Ord. I44. Podostemaceae. Tropical aquatic-plants.

Ord. I45. Nepenthaceae. Pitcher-plants in the small Stovehouse.

Ord. I47. Aristolochiaceae. The Birthworts or Dutchman's Pipes are tall climbers, which may be seen both east and west of the East Wall. The rare Asarum europaeum is the only British species. Aristolochia clematitis has been recorded from Godstow and from Studley Priory-both sites of former monastic establishments.

Ord. I48. Piperaceae. The Saururean Tribe only is represented by Houttuynia cordata, a common Chinese weed first grown in Oxford about 1855 . The flowers have neither sepals nor petals. Both Piper and Peperomia are grown in the Stoves.

Ord. I50. Myristicaceae. Nutmegs, $M$. moschata, from the Malay Archipelago.

Ord. I52. LaURACEAE. The Sweet Bay, Laurus nobilis, will be found against the West Wall. It is not quite hardy, being cut back by hard frosts. Cinnamomum, Camphora, and Greenheart, Nectandra rodiaei, are exotics of this order.

Ord. 153. Proteaceae. South African and Australian shrubs and trees, represented by Grevillea in Conservatory No. 4.

Ord. I54. Thymelaeaceae. Daphne mezereum and laureola are the only two English species. Like Elaeagnaceae, the Thymelaeaceae are now believed to have lost their petals.

Ord. 156. Elaeagnaceae. The Sea Buckthorn, Hippophaë rhamnoides, yields fruit from which a tolerable preserve can be made. A small tree is growing in the centre of the plot.

Ord. 157. LoRanthaceae will be found overhead upon the Ostrya carpinifolia at the southern end of the plot. The Mistletoe, Viscum album, usually occurs upon the Rosaceous trees, the apple, mountain ash, hawthorn, and upon poplars (especially in the Loire Valley), but in our Garden it grew 
on the Walnut and Crataegus prunifolia* $*$ in 1864 , and has extended its range to the Horse-chestnut, Lime, Cladrastis, Crataegus oxyacantha, and to the Ostrya, and lately to the Medlar. It propagated by rubbing a ripe berry on a smooth healthy bark surface, until the gelatinous matter about the socalled seed makes it adhere.

Ord. 158. Santalaceae. The Indian Sandalwood-tree, Santalum album, is represented in England by the herb Bustard Toadflax, Thesium linophyllum, found on the chalk.

Ord. i6o. Euphorbiaceae. The Spurges are characterised by their poisonous milky juice, which is used by country folk for destroying warts, and which may one day have an economic future as the source of indiarubber, as it is in the Central American Siphonia elastica. A bed in the south-east corner of the plot is devoted to Castor-oil-plants, Ricinus communis. It is stated that half a dozen of the green seeds when eaten will act medicinally: they would certainly be easier to take than the oil which is expressed from them.

The exotic Euphorbias are of the most varied appearance. Many of the leafless succulents may be seen in the Cactus House; while in the warm Stoves are the Poinsettia, with its bright red leaf-like inflorescence, the fine-foliaged Crotons, and the useful Manihot-the source of cassava and tapioca.

Related to the Euphorbias is the shrubby tribe of

BUXACEAE. Box hedges and edgings are used in several parts of the Garden. The tree standing near the Danby Gate, outside the wall, measures $2 \mathrm{ft}$. in girth, and is one of the largest in Oxford.

* On this tree the Mistletoe made a clump $4 \mathrm{ft}$. in diameter, and a thrush built its nest therein (Gardeners' Chronicle, 1864). In 1901 a list of trees infected was indirectly supplied to the Gardeners' Chronicle by Mr. Baker. The list included the above-mentioned trees (except the Medlar and C. prunifoiia), and added Crat. odoratissima, Acer monspessulanum, Aesculus hippocastaneum, Pyrus aria, Salix alba, and Fraxinus ornus. But on the four last, the growth was weak. Perhaps some of our scientific botanists have had a hand in the dispersal. 
In the south-east corner of Plot $\mathrm{F}$ are the herbaceous

Ord. 162. URTicaceae, or Nettles, several of which supply valuable textile fibres, manufactured by the Chinese, and in India. Even the bast fibres of the Common Stinging Nettle,* Urtica dioica, have been made into thread and lace in Ireland.

Closely allied are the

Cannabineae, or Hemp Tribe, with which the Hop, Humulus lupulus, has also been associated. The fibre of Cannabis sativa may be $8 \mathrm{ft}$. to $9 \mathrm{ft}$. in length. C. indica gives intoxicating properties to Arabian hashisch (whence the word assassin) and to Indian bhang, the demoralising effects of which are well known. Also the

Moraceae or Mulberries, including Broussonettia (see p. 42), the inedible Osage Orange, Maclura aurantiaca, and the various forms of Figs. And lastly the

Artocarpeae, the Bread and Jack Fruits, and other tropical genera such as Cecropia, the Trumpet Tree and Galactodendron (Brosimum galactodendron), the Cow Tree, a forest tree which yields an agreeable liquid food to the natives of Venezuela.

The order UlmaceaE, sometimes regarded as Ulmeae, a tribe of the Urticaceae, comprise the Elm-tre es which flourish greatly alongside their humble relations the Stinging Nettles in the Grove of Magdalen College, where, until the storm of April IgI I, grew the giant of the race. Stated to have been the largest timber tree 'but one in all England, its dimensions are worthy of record (see Magdalen College, in Appendix E, p. 218).

* The following is the form in which Mr. Cox tells the story about Dr. Daubeny's lecture on Nettles, save that he attributes it to Sibthorp. Several specimens and species were carefully laid out on the lecture-table. "Now, gentlemen, we all know, from our childhood, that some of the nettle family have a powerful pungent property; others a less powerful, less pungent property; and others again none at all, or next to none. Now to begin with the last species, this you see " (suiting the action to the word) "may safely be drawn through the hand, thus"-some wicked wag, while the doctor's back was turned, had impudently changed the order in which the specimens lay, or the Professor had unwittingly laid a trap for himself. The effect may be imagined !

According to another version, he precipitately left the room. 
Catkin-bearing trees, or Amentaceae, comprise Nos. 163-169. Ord. 163. Platanaceae. Planes.

Ord. 165. Juglandaceae. Walnuts.

Ord. I66. MyriCACEAE. Sweet Gale; Bog Myrtle, Myrica gale, is abundant in Scotland and on the northern moors of England.

Ord. 167. Casuarinaceae. Australian trees in Conservatory No. 4.

Ord. I68
Cupuliferae. $\left\{\begin{array}{ll}\text { Fagaceae. } & \text { Oaks, Beeches, and Chestnuts. } \\ \text { Coryleae. } & \text { Hazels and Hornbeams. } \\ \text { Betuleae. } & \text { Alders and Birches. }\end{array}\right\} \begin{gathered}\text { Cf. the } \\ \text { chapter on } \\ \text { Trees. }\end{gathered}$

Ord. I69. SalicaceaE or Willows have a bed in this plot just under the S. European Hornbeam, Ostrya carpinifolia (Coryleae), and have already been described on p. 49. The Poplars are better out of the Garden.

Ord. 171. Empetraceae. The Crowberry, Empetrum nigrum, is a heath-like shrub.

\section{MONOCOTYLEDONS}

The two plots on the west side of the Garden are laid out so as to illustrate the Hardy Herbaceous Monocotyledonous Plants.

For a long time the Monocotyledons were regarded as being more primitive than the Dicotyledons, but recently a view has been expressed that they have been derived from Dicotyledonous plants, by degeneration consequent upon having lived originally in water in warm countries, so that they cannot now, as land plants, recover to the full the power necessary to construct such tissues as are found in Dicotyledons capable of resisting the injurious effects of cold climates.*

Consequently it is in the Palm Houses that the finest and most typical examples must be sought ; and in comparison with these, the out-of-door plants appear as starvelings.

Ord. I73. HYDROCHARIDEAE. Water-plants originally confined in Britain to East Anglia, but one species, Elodea (Anacharis) canadensis, invaded the waterways of this country about 1847 , and is now one of our commonest weeds in canals and ponds. Vallisneria spiralis of S. Europe has a considerable sale among amateurs of fresh-water aquaria. The male flowers break loose and float about, thus effecting the fertilisation of the

$$
\text { * Henslow, "Annals of Botany," xxv. p. } 720 .
$$


female flowers. The Water Soldier, Stratiotes aloides, is abundant in the Fens, and I have found it at Nuneham.

Ord. I74. Burmanniaceae.

Ord. I75. ORCHIDACEAE. A few hardy Orchids are grown in pots near the south pond ; but for the exotics, see Orchid House, No. 9.

Ord. I76. ZingiberaceAe (Scitamineae, in part), or Gingers, with which the Marantas and Cannas are sometimes united, are mostly in the Stove and Palm Houses, but in the summer the Cannas are bedded out of doors.

Ord. I77. Musaceae (Scitamineae, in part). The Bananas are cultivated in the Water-lily House.

Ord. 178. Bromeliaceae. Pine Apples. See under Water-lily House, No. 6, pp. I06-7.

Ord. I 79. HaEmodoraceae. Bowstring Hemp.

\section{PLOT G}

Ord. I80. Iridaceae. Two long beds at the north-east are devoted to this beautiful order of plants. A notable addition was made to the collection in 1890 , when a selection of Irises was presented by Professor Sir Michael Foster of Cambridge. Others will be found between the South Wall and Christ Church Meadow in the "Iris bed," which is one of the glories of the Garden in the middle of the Summer Term. The Florentine Iris is cultivated in Tuscany for its roots, which, under the name Giaggiola or Orris-root, is the basis of the scent "Essence of Violets."

In addition to the Flag Iris family there are the Tiger flowers, Tigridia pavonia ; Hermodactylus tuberosus, S. Europe ; Sisyrinchium striatum, from China, a noble plant in June; Watsonia ardernei in Green-house No. 3 or 4 ; here too belong species of Ixia Gladiolus, Montbretia, and Crocus.

Ord. I8r. Amaryllidaceae. The bulbous section of this the Narcissus Order includes the Snowdrop, Galanthus nivalis; Snowflakes, Leucojum vernum, and aestivum; and Daffodils in the open; while under glass are the Scarborough Lilies, Vallota; Crinum and Pancratium. The Agave sp., or American Aloes, and Furcraea, which also belongs here, are in 
the Cactus House. The Peruvian Lily, Alstroemeria, representing the third section of the order, is planted in a special bed near a Juniperus sphaerica.

Ord. I82. Taccaceae. Perennial stove herbs.

Ord. I 83. Dioscoreaceae. Yams are the starchy roots of the tropical climber Dioscorea sativa, and of other species. The English member of the order is the Black Bryony, Tamus communis. The S. African Hottentot's Bread, or Elephant's Foot, Testudinaria elephantipes, is grown in No. I 2 Green-house.

Ord. I 85. LiLiacEAE. The Lily order contains several divisions of plants which are at first sight very unlike one another-e.g. Butcher's Broom, Aloes, and Onions.

i. The Lilies proper include the Snake's Heads, Fritillaria meleagris, so local in England and so abundant in the neighbouring water-meadows of Magdalen College and at Iffley. F. imperialis, a native of Persia, imported into Constantinople in the sixteenth century, obtained its name from having been grown in the Imperial Garden at Vienna. Near by are the 'Tulips and Dog-tooth Violets, Erythronium, and in a middle cross-bed the Scillea, including Puschkinia; Grape Hyacinths, Muscari; Camassia esculenta; Star of Bethlehem, Ornithogalum narbonense and pyrenaicum. The Yellow Tulip, T. sylvestris, used to grow in Christ Church Meadow (p. I33).

ii. Of the Colchicoideae we have out of doors C. byzanticum and autumnale, the Autumn Crocus; Veratrum nigrum; White Hellebore, much used by veterinary surgeons, is $V$. album ; while in the Water-lily House are the beautiful Gloriosa Lilies, of which $G$. rothschildiana is especially admired.

iii. Another bed is devoted to the third or Asphodel group, containing Eremurus and Hemerocallis.

Under glass we have the New Zealand Flax, Phormium tenax; Kniphofia in the Stove; and in the Cactus House, the true Aloes and their relations-e.g. Gasteria.

iv. The Leeks and Onions are in a long bed near the Yucca, the representative of the Dracaenoideae. 
v. The Dracaenoids, or Dragon Trees are mostly, in the Glass-houses. A plant of Yucca gloriosa flowered in July, 1835, when twelve years old. The flower-stem was $8 \mathrm{ft}$. long and bore 827 flowers, described in detail in the Gardeners' Magazine for that year. 'The Dasylirions in the Cactus House are especially fine.

vi. With the Asparagus group (bed next the Yams) are associated the Lily of the Valley, Convallaria majalis; Solomon's Seal, Polygonatum.

"The roote of Solomon's Seale . . . taketh away in one night, or two at the most, any bruse, black or blew spots gotten by fals or womens wilfulness, in stumbling upon their hasty husbands fists, or such like."GERARD, p. 758 .

In the remarkable Butcher's Broom, Ruscus, the branches have become leaf-like. Rohdea japonica is related to the Parlour Palm, Aspidistra.

vii. Smilax will be found climbing both east and west of the East Wall. The roots of $S$. officinalis, papyracea, and medica yield the sarsaparilla from Jamaica, Brazil, and Mexico respectively.

viii. The beautiful green-house climber Lapageria is the type of another of the sub-orders of the Liliaceae.

Ord. I86. Pontederiaceae are tropical aquatics from the New World. Eichhornia grows luxuriantly in the Water-lily House.

Ord. 188. XYRIDEAE are swamp-dwellers in hot countries.

Ord. I90. Commelinaceae, or Spiderworts, mostly require stove treatment, but the Tradescantias in the south-west corner bed are hardy. They were named in honour of the younger Tradescant, who brought one from Virginia, and whose father so nearly became first Curator of the Garden. Palisota is a stove plant.

Ord. 192. Flagellarieae. Susum.

Ord. 193. Juncaceae. Rushes, Juncus and Luzula.

Ord. 194. Palmaceae.
Ord. 195. Pandanaceae. Screw Pines. $\}$ See Palm House, No. 8.

Ord. 196. Cyclanthaceae. Carludovica.)

Ord. 197. Typhaceae. The Bur reeds, Sparganium, and Bulrushes, Typha, are grown in the ponds. 


\section{PLOT H}

To the south of the cross walk in the corner are a few of the

Ord. I98. ARACEAE, which are hardy with us; the larger and more showy Aroids will be found in the houses. See Amorphophallus, Caladium, Richardia, or Calla.

The Dracunculus vulgaris from S. Europe suffices to indicate how fine Lords and Ladies may grow in warmer climes.*

Ord. 199. Lemnaceae. The Duckweeds growing on the surface of ronds may have been derived from such an aquatic Aroid as Pistia stratiotes.

Ord. 201. Alismaceae. Water Plantains live on the water's edge, Alisma plantago; Arrowhead, Sagittaria sagittaefolia; Flowering Rush, Butomus umbellatus (often made the type of a separate order, including Limnocharis). Echinodorus is a tropical form (p. 106).

Ord. 202. NaiAdaceae. Pondweeds, Potamogeton. Aponogeton distachyon comes from the Cape of Good Hope. The flowers have a very sweet scent resembling that of hawthorn-blossom. Ouvirandra, see p. Io6.

Ord. 203. Eriocaulonaceae. E. septangulare, Jointed Pipewort, is a N. American species found on the west coast of Ireland and in the lakes of Skye.

Ord. 205. Restiaceae. S. African herbaceous plants.

Ord. 206. Cyperaceae. Sedges. Carex tomentosa, the rare Marston Maisey Sedge, was cultivated by Baxter, and is still in the collection. The Papyrus, grown in the Water-lily House, belongs to this order (see p. I02).

Ord. 207. Gramineae. The Grasses are arranged in six beds, commencing with the Panicoideae, the Millets, Panicum miliaceum, and Maizes, Zea mais; and, passing on to the Agrostideae, with the genera Apera, Milium, Fox-tail Grass Alopecurus, and Phleum; next we come to the Oat

* The spots upon the leaves of the Common Arum have been explained by an Oxford poet. See "Arum Maculatum," a poem by P. Duncan, once Keeper of the Ashmolean Museum.

Flora to Zephyrus once wrote

A very charming little note

All about sighs and smiles and grief,

And dropt her ink upon this leaf. 
Grasses, Aveneae, and the Fescue Grasses, Festuceae, and their genera. The Hordeae, including Rye, Barley, and Wheat, are economically the most important of all, and the collection ends with the Bamboos in the corner bed.

In 1824 Professor Schultes praised the attention then given to Grasses by the gardener, Mr. Baxter, who, from the experience of several years, was "enabled to decide that Agrostis verticillata, vulgaris, decumbens, fasciculata (Curt.), and stolonifera are distinct species, which, when subjected to the same culture for a great length of time, still continue to preserve their characteristic marks." Baxter's grasses have mostly made way for more popular plants.

\section{GYMNOSPERMS}

To complete our systematic review of the Plants of the Garden we append an outline classification of the Gymnosperms. A few species have already been mentioned in the chapter on Trees.

Ord. 208. GNeTACEAE. A fine Ephedra distachya is growing against the West Wall. A specimen of the highly remarkable Welzwitschia is to be seen in the Museum.

Ord. 209. Coniferae. See p. 47 .

Sub-ord. i. Pinoideae.

Tribe A. Abietineae.

Fam. I. Araucarinae. The Puzzle Monkeys.

2. Abietinae.

Pinus, Cedrus, Larix, Picea, Tsuga, Abies.

3. Taxodinae.

Tribe $\mathrm{B}$.

Sequoia, Cryptomeria, Taxodium.

Fam. 4. Cupressineae.

Thuja,Libocedrus, Cupressus, Chamaecyparis, Callitris, Fitzroya.

5. Juniperinae.

Sub-ord. ii. Taxoideae.

Podocarpus, Taxus, Torreya, Cephalotaxus, Phyllocladus, Ginkgo.

Ord. 210. Crcadaceae. Species of Zamia, Encephalartos, Dioon, Bowenia, and Stangeria are all represented in the Stove-houses. 


\section{The Hardy Ferns}

The collection of Hardy Ferns was entirely rearranged along the eastern border in 1892, when the bed was brought into proper condition with suitable compost. The border was remade in 1909 ; but it is still very far from our ideal of the kind of habitat in which ferns luxuriate when in a state of nature.

There is a good representative series of Polystichum, Lastraea, and others, and also a collection of those sports and monstrosities of leaf-form which are so highly prized by many fern-growers, but which in a Botanical Garden are perhaps of less interest than many other plants-e.g. Fungi or Mosses.

The Royal Fern, Osmunda regalis, does not do very wellperhaps the winters are too cold. The glamour which surrounds this fine fern is unfortunately slowly but surely tending towards its extinction in Britain.

In the south-east corner are

\section{The Horse-Tails}

Horse-tails, Equisetum, are the poor descendants of a great and ancient family which has been "coming down in the world " ever since Palaeozoic times. The clump of Horse-tails in the south-east corner is a useful reminder of what forests were like in early geological times. If we imagine these plants with stems 8 inches thick and high in proportion, we shall have a mental picture of a forest of Equisetites arenaceus in the Triassic Period. The Calamite Trees of the coal-measures reached a higher stage of development still, for in them, in addition to other structures, secondary wood was formed, just as it is in a modern forest-tree. Some of them had a pith one foot in diameter!

\section{The Southern Herbaceous Garden}

In the seventeenth century this land was so subject to floods that it was not cultivated, but by Baxter's time the gardeners had made a practice of using it as a Kitchen Garden. Dr. 
Daubeny raised the level of the ground considerably, moved the collection of Grasses there, and in order to draw attention to one of the original purposes of the Botanic Garden as a Physic Garden or receptacle for Medicinal Herbs, reserved the portion outside the south corner of the walls for such plants of a hardy nature as were admitted into the Pharmacopoeias on the score of their therapeutic virtues. But the collection has now been distributed, and the Aconite, the Hellebore, the Liquorice, the Valerian, the Saffron, the Poisonous Lettuce, Rhubarb, Henbane, Belladonna, Colchicum, and many more may now be found with their near relations in the Systematic beds within the walls.

In their place will now be found borders along No. I 2 Green-house (remade and raised in 1903) and six long herbaceous beds, having in summer all the charm and beauty of a mixed herbaceous border; and many are the suggestions of new plants or of effective arrangement they afford;

Full gay was all the ground and queint

And poudred as men had it peint,

With many a fresh and sundry flour

That casten up full good savour.-ChAUCER.

The bed next the path is reserved for the collection of Irises, mostly horticultural varieties, which do remarkably well here, and are the chief attraction of the flower-garden in the middle of the Summer Term. The plot faces south and is well sheltered on both sides.

Just within the south boundary fence, and partly within and partly without the line of boundary stones which divide the land of Magdalen College from that of Christ Church, are three Rose-beds filled with dwarf Roses and with Dahlias in their season. This year, in October, there was a fine show of red Salvia.

The path to the right leads to a turnstile under a yew near the Cottage, and a wicket in the wall gives egress to Rose Lane. 


\section{THE HARDY AQUATIC PLANTS}

The ripples seem right glad to reach those cresses, And cool themselves among the emerald tresses; The while they cool themselves, they freshness give, And moisture, that the bowery green may live : So keeping up an interchange of favours, Like good men in the truth of their behaviours.-KeA'Ts.

As is natural in a low-lying garden on the banks of the Cherwell, and in its early days constantly menaced by floods, marsh and aquatic plants were not difficult to cultivate. Robert Sharrock, in his "Improvement to the Art of Gardening," third edition, informs us that "The Artificial Bog is made by digging a hole in any stiff clay, and filling it with earth taken from a bog . . . of this sort. In our Garden here in Oxford, we have one artificially made by Bobart, for the preservation of Boggy plants, where, being sometimes watered, they thrive for a year or two as well as in their natural places."

Baxter cultivated his smaller aquatics in the south-east corner of the Garden in a series of small square tanks, each a foot across, which had been constructed for the purpose by Dr. Sibthorp, and which lasted for more than half a century with very little need of repair. Among other moisture-loving species, Sibthorpia europaea was most appropriately grown there.

The present inadequate provision for Hardy Aquatics consists of two old cement tanks made in I834, as part of Dr. Daubeny's original plan, at a cost of $£ \mathrm{r} 448 s$. $6 d$., and frequent frosts have greatly increased the outlay upon them. The smaller plants are grown in small compartments upon a raised shelf round the periphery of the tanks. 


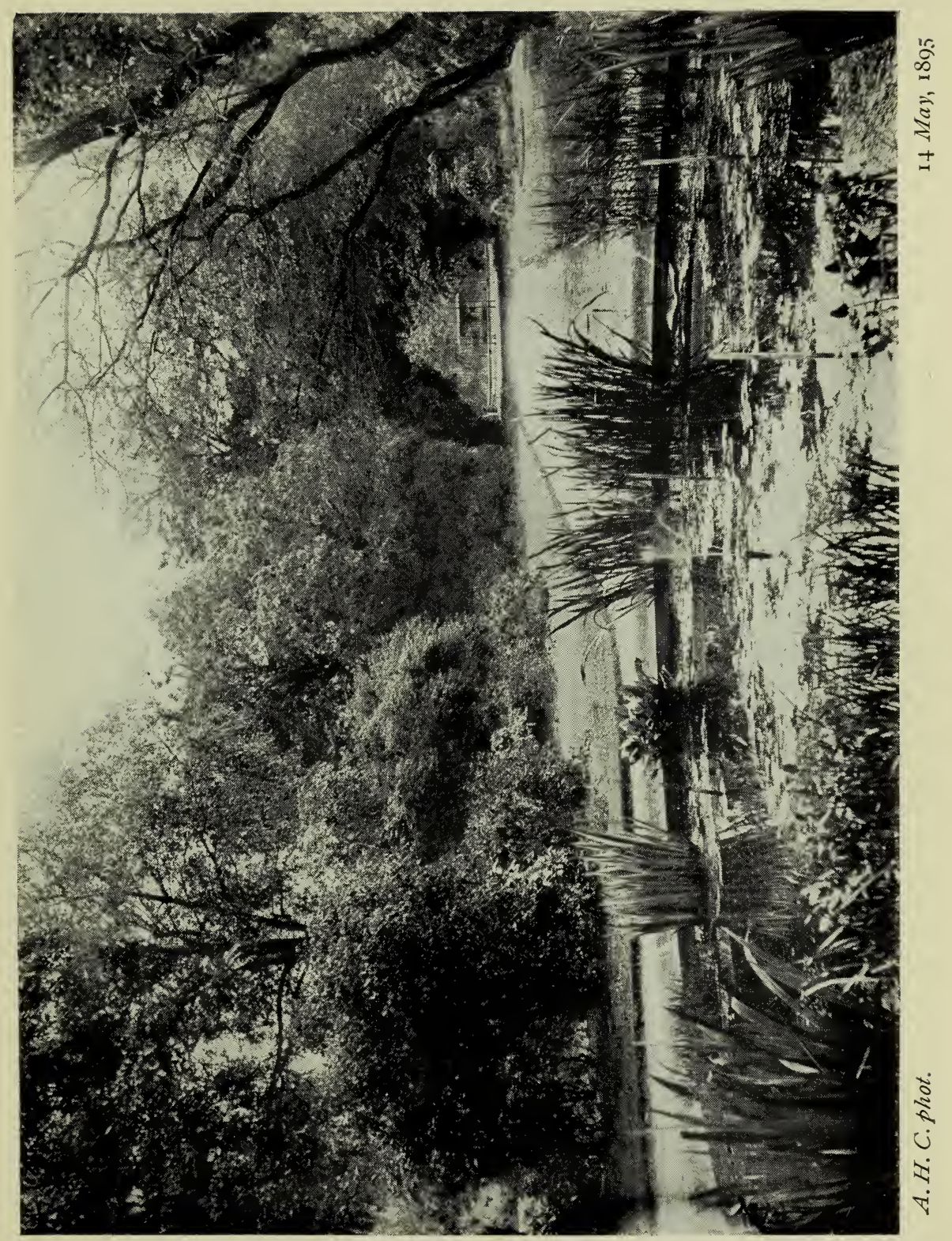

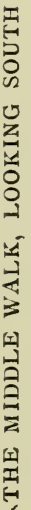




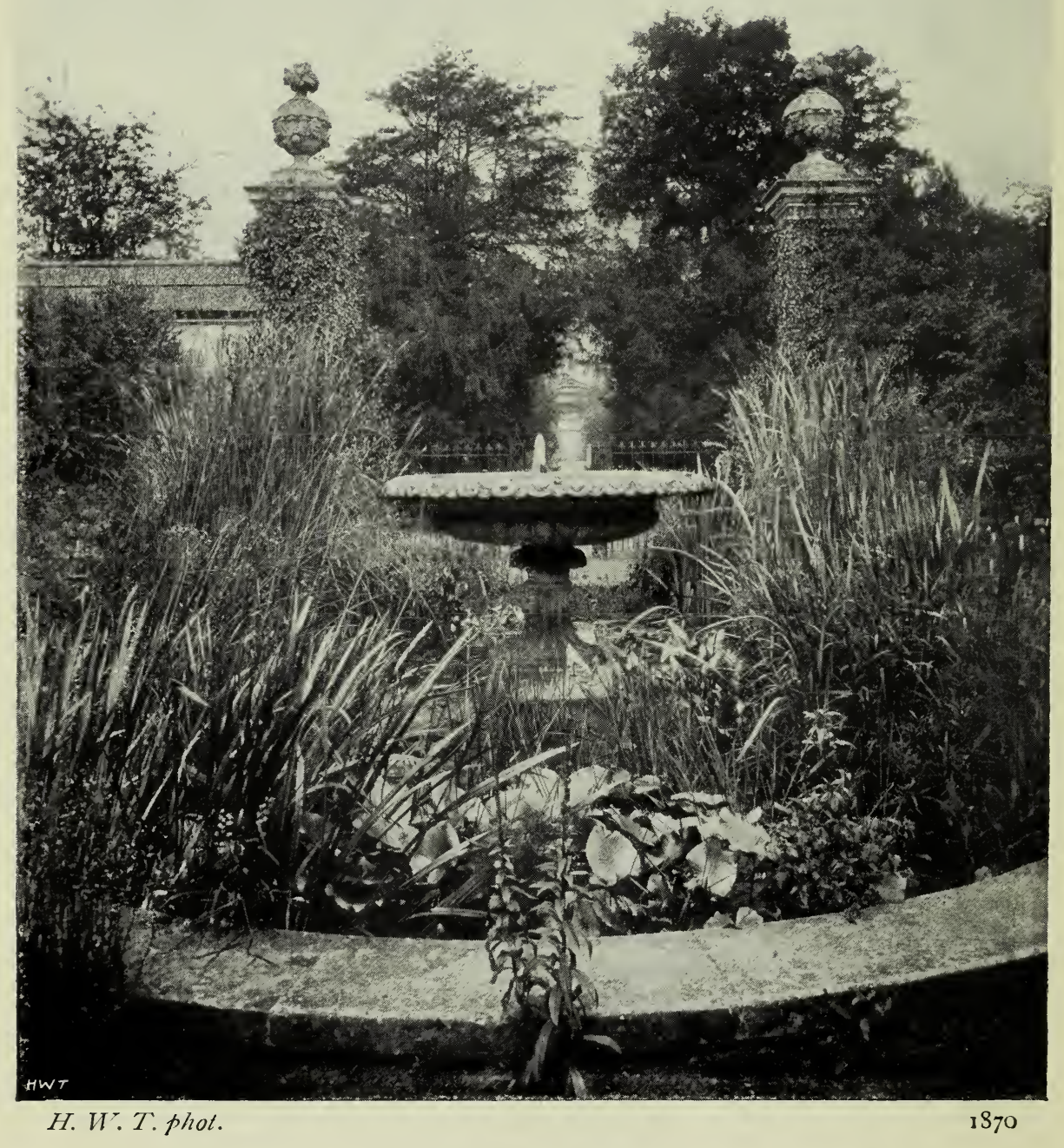

THE FOUNTAIN IN SUMMER 



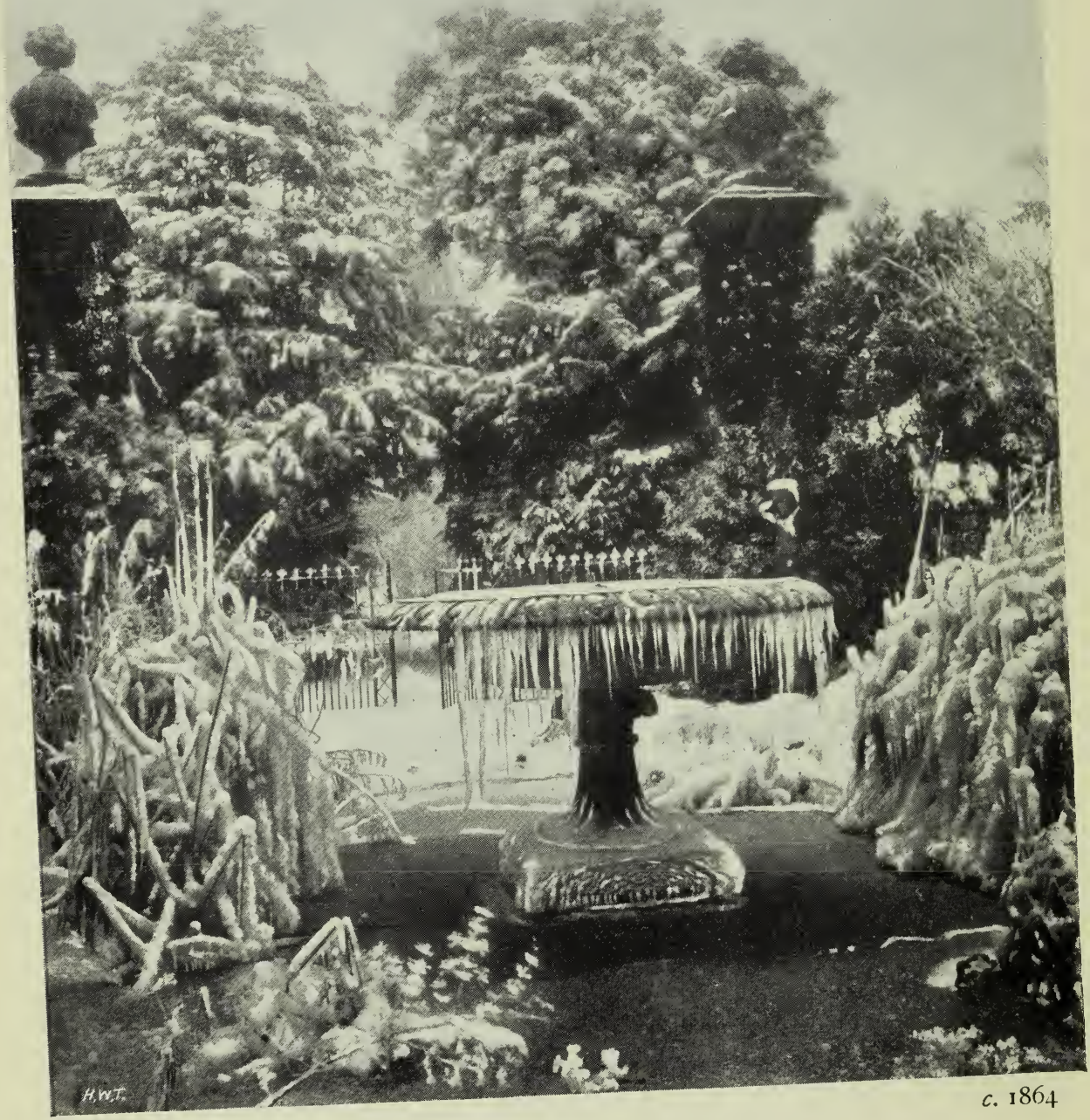

H. W.T. phot. 
In the small Fountain-pond* in the middle of the Garden grow a few Water-lilies, Flags, and Arrow-heads, and an abundant microscopic flora of algae and small pond animals; while just beyond the South Gate, in an enclosure closed to the public, is the second, an oval tank originally intended for exotic water-plants. It was into this tank that a small plant of the Canadian Water Thyme, Anacharis alsinastrum, was introduced about I850. It had not previously been known in this county, but in a marvellously short space of time it spread everywhere. A ditch in the Long Meadow had become filled with "an uninterrupted dense mass" by August, I 853 (Baxter MS. Druce's "Flor. Oxf."). It now contains some of Latour-Marliac's hybrid Water-lilies, Reeds, Arrow-heads, and other Aquatics. It is surrounded by concentric steps, upon which the collection of "Alpine Plants" is displayed during the summer months. $t$ They go into cold frames in the winter. A flower of the Bog Bean, Menyanthes trifoliata, grown in the Garden was figured in Mr. Baker's article on Aquatic Plants. Aponogeton distachyon has a curious toothbrush-shaped flower with a hawthorn scent.

As we have remarked elsewhere, it is a great pity that greater advantage should not be taken of the favourable situation of the Garden for the extension of its Marsh and Aquatic Department. A supplementary supply of water might, if wanted, be obtained by means of a ram at Holywell Mill sluice.

* Neither of our ponds was the one in which Mrs. John Tradescant drowned herself on April 3, 1678, out of chagrin at the decision of the Court of Chancery, in consequence of which, her deceased husband's wonderful "closet of curiosities" was carried off to Oxford to pose as "Ashmole's" Museum. That pond was in the Botanic Garden in South Lambeth. But the round pond was the one into which the Professor of Botany (circ. I880) inadvertently plunged when learning to ride one of the old high bicycles in the Garden after the closing hour.

$\dagger$ The practice of putting out pot-plants in this quarter dates from the time of the elder Bobart. Loggan's plan shows twenty-eight large pots there in $\mathbf{1 6 7 5 . ~ W a t e r ~ w a s ~ o b t a i n e d ~ f r o m ~ t h e ~ d i t c h ~ b y ~ m e a n s ~ o f ~ a ~ p u m p . ~}$ 


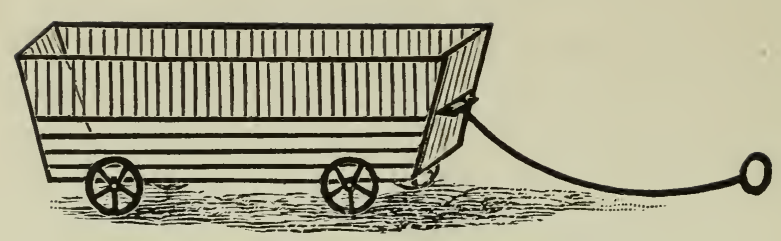

The Oxford Heating Apparatus

\section{THE GLASS-HOUSES}

Who loves a garden, loves a greenhouse too.

Unconscious of a less propitious clime,

There blooms exotic beauty, warm and snug,

While the winds whistle, and the snows descend.-CowPER.

Historical.-The first conservatory or shelter for "tender greens" was, as shown in Loggan's plan of the Garden (p. 7), a long, low stone Orangery along the London Road, of sufficient solidity to admit of transformation early in the eighteenth century into the herbarium, library, and professorial residence (p. I5). By I710, two small glass-houses had been added to it, one at each end. In I776 it was pulled down to make room for a more commodious house of two or three stories, which was in turn demolished that the approach to the new bridge might be widened.

In those early days, before the extensive use of glass, and before the introduction of any efficient heating apparatus, the massive walls of stone conservatories open to the south, would have not only afforded efficient shelter to the plants, but by getting warmed by the sun during the day would have slowly radiated heat by night, and thus have checked the chilling of the plants. A massive building might thus have had advantages over a light modern structure of glass and wood. In very severe weather a four-wheeled wagon * was filled with burning charcoal, and was drawn backwards and forwards along the path by the gardener.

At an early date the first conservatory was replaced by the Eastern Architectural Conservatory, still partly standing to the east of the Danby Gate, and which is said to have been erected by James Sherard, brother of the Consul (Dillenius" "Letters"). A "new herb house" is mentioned in Wood's Diary under date May 21, I695. It had soon, in I7I5, to be enlarged to receive a collection of curious exotics presented by

* We owe our illustration to the courtesy of the Editor of the Gardeners' Chronicle, the journal in which it appeared as Fig. I63 on p. 732 , in 1885 . 
Bishop Robinson, the benefactor of Oriel College.* Like its predecessor, the conservatory was afterwards used as a receptacle for books instead of plants, and lectures were given therein. In the absence of more precise information, it may be supposed that the large sum of $£ 2,257$ 8s. $7 d$., spent "chiefly on new buildings" between Michaelmas, I734, and Michaelmas, I736, was for the two Architectural Conservatories within the walls, for the wooden Green-houses described below, $\dagger$ and for the alterations to the Library, in consequence of the frequent declaration of Sherard that he intended to leave his books to the University. It is even stated that he saw and approved the plans.

The third, or Western Architectural Conservatory, measured $66 \mathrm{ft}$. long by $22 \mathrm{ft}$. wide in the centre, and $13 \frac{1}{2} \mathrm{ft}$. high; it remained in use as a plant-house till $\mathbf{I} 853$, when $£ \mathrm{I}, 250$ was spent to adapt it to receive the Fielding Herbarium, and new green-houses were erected in its place. Other alterations foliowed, but parts of its original fabric may still be seen sandwiched between the white walls of I9II. The period of Architectural Conservatories is now of the past in this country, though one is still in use at Kew. They are better adapted for climates in which the winter sun has greater strength than in ours, and in which, in summer, grateful shade is afforded by the massive piers.

The first wooden Green-houses, $30 \mathrm{ft}$. long by Io $\mathrm{ft}$. wide by $14 \mathrm{ft}$. high in front, but only Io $\mathrm{ft}$. high at the back, were erected on both sides of the Danby Gate adjoining the Architectural Conservatories. They were lean-to, with steep-sloping sash-lights below round-headed top-lights. They stood from I734 till I834, being then condemned by Daubeny. A good engraving of them was published in the Oxford Almanack for 1766, and a later view appeared in 1836 in Ingram's "Memorials of Oxford." $\ddagger$ They were replaced by lean-to houses, of which the western one was known as No. 2 (1834-79) and the eastern one as No. 3 Greenhouse, which is still standing. No. I Green-house, a house of the same

* Rawl. MS., "Chron. Univ.," quoted by Wood. Daubeny states that Sherard gave $£ 500$ for the enlargement of a conservatory which was finished by March, I 726-7.

+ Perhaps they were the Green-houses mentioned by Dillenius in a letter to Richardson. and which "Sherard was having built about July I I, 1734" (Druce, "Dill. Herb."). Of the same date, if not older, was the "Stove House," $30 \mathrm{ft}$. by I $4 \mathrm{ft}$. by $12 \mathrm{ft}$. high, a detached building with glass only on one side, which was still standing in 1834 outside the wall near the site of the present Palm House.

‡ A ground-plan showing these houses, engraved by Hollis, was printed by Daubeny. It was inscribed "Hortus Botanicus Oxonii." 
style, stood in the north-west corner of the Garden, on the site of the present Lecture Room. It contained the Succulents until 1875.

In Daubeny's time the Garden was better equipped with conservatories, or cool green-houses, than it is at present, but the area of the stoves was not so large.

In 1875 , No. I was pronounced ruinous, the.plants were removed, and Professor Lawson held a practical class in it, and afterwards erected his new Class Room on the site. In the following year Nos. 2 and 3, which were smoke flue-heated, were condemned as being as "inefficient as costly," and soon after, No. 2 gave place to a Laboratory.

With the encroachment of the Laboratory upon the Garden, we may note the disappearance of the larger conservatory plants, as, for instance, of the aged orange-trees procured from Genoa by the Duke of Buckinghan, and purchased for the Garden in 1850 .

In our description of the various Glass-houses we shall endeavour to mention a few of the more noteworthy plants which have been seen in each of the houses, but visitors must remember that the plants are not always there. The floral tenants of Green-houses are like hotel guests, and change with the seasons of the year; some to go to a warmer climate, others out of doors, while others again are only exhibited in the houses open to the public for decorative purposes while in flower.

And not the least are the seasonal changes in the flora of No. 4 Conservatory.

The existing cool-houses are known as Nos. 3, 4, and 12, of which No. 4 is the only one open to the public.

\section{No. 3 Green-house}

No. 3 Green-house, standing to the east of the Danby Gate, was built in 1846 , and is in a ruinous condition. It is often used for experimental work in connection with the Laboratory, and is closed to the public. The collection of bulbous plants from the Cape of Good Hope is usually housed here: species of Haemanthus, Ornithogalum, Eucomis, Crocosmia, Lachenalia, Moraea glaucopis, and Wurmbea capensis amongst others. 
Also several S. American Zephyranthes and Ismene (= Hymenocallis). There are also a few Crassula and Echeveria species.

\section{No. 4 Conservatory}

The first conservatory of more modern type was built in I $835^{*}$ with money left by Professor Williams for the purpose. It was rebuilt on a somewhat larger scale, and has recently been enlarged to a size of about $60 \mathrm{ft}$. by $25 \mathrm{ft}$. on the square. It contains the larger-growing cool-house shrubs and trees, the temperate ferns at the back, and green-house flowering plants in the front.

In the middle are several of the less hardy Coniferae.

A common parlour plant, but also the most majestic of its tribe, is the Norfolk Island Pine, Araucaria excelsa, which rises to a height of more than $200 \mathrm{ft}$. in its native country, and is remarkable for its graceful spreading pendulous branches. It has been extensively used for making the masts and spars of ships : unfortunately it soon outgrows the size of the house, and fine trees have to be removed from time to time.

Fitzroya patagonica is another large tree, the native of an inclement region, but not sufficiently hardy to be planted out with us.

The hardier Palms are represented by the Date Palm, Phoenix dactylifera, which bears its fruit at a height of $60 \mathrm{ft}$. from the ground in N. Africa; and Chamaerops excelsa, a large specimen of which was presented by Miss Acland in 190r.†

The remarkable tribe of Australian plants, the Casuarinae, resembling in some respects the Coniferae, but with long and slender branches, are represented by Casuarina equisetifolia.

Among the more highly organised plants are the Grevilleas (robusta, alpina, juniperina var. sulphurea), elegant shrubs

* We believe this to have been the house, then a stove, into which Kewley's hot-water apparatus was fitted in 1837 .

$\dagger$ Miss Acland also presented fine Cordyline australis, Myrtus communis, and Phormiun tenax in the same year. 
and trees of the Southern Hemisphere, which, with their relatives, Banksia, Protea, and Dryandra, all belong to the order Proteaceae. G. robusta is the Silky Oak of Australia, prized for its beautiful wood. Protea argentea received its appropriate name of Silver Tree from the silvery sheen of its leaves, well-known at the Cape of Good Hope. Stenocarpus cunninghami was grown in 1860 .

The light foliage of the Wattles or true Acacias from Australia will attract attention. In many species the lamina or broad part of the leaf drops off, whilst the leaf-stalk expands so as to form a substitute for it. The white or yellow flowers, like clustered miniature puffs, are readily distinguished from those of the False Acacias or Robinias of $\mathrm{N}$. America, which are papilionaceous. In the collection are A. baileyana, cordata, dealbata, riceana, and suaveolens.

Here (or in No. I2) may be seen the Carob, Ceratonia siliqua, the pods of which are much used for feeding animals in S. Europe and Sicily, and are imported for mixing with the concentrated cattle-foods of this country. The small seeds were used by jewellers as carat-weights.

The Camellia, nearly allied to the Tea-plant, was introduced into Europe from China by Lord Petre in 1739, and has long been cultivated in the Garden. Raphiolepis ovata is a Japanese shrub with glossy dark green leaves.

Such are the principal plants of large size in the conservatory (or No. 12 Green-house), but its gay appearance at most seasons is due to the smaller flowering herbs on the staging near the glass. Here, in their season, may be seen

Flowers of all heavens, and lovelier than their names (TENnyson), such as Cinerarias, Primulas, Vallota Lilies, and Heliotropes, believed by the Greeks to have been produced by Apollo at the transformation of Clytia; also large specimens of Agapanthus, the finest of onions.

Towards the end of October the stages are swept clear and 


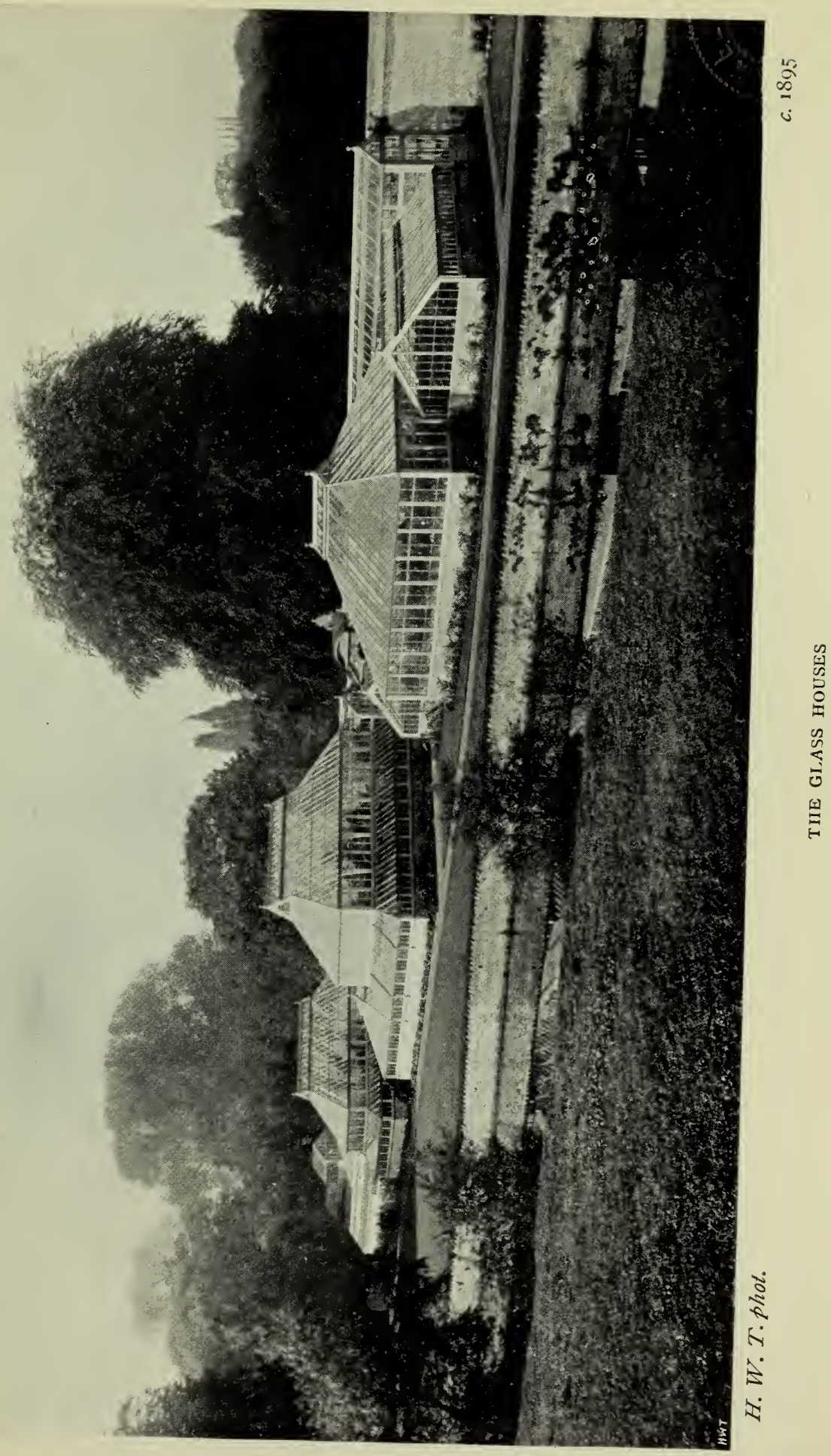



the other plants are huddled together to make room for the annual winter exhibition of florists' varieties of Chrysanthemums, at once the admiration and envy of many a private grower in Oxford, a town famous for the Winter Show* of the Oxfordshire Chrysanthemum Society, the jubilee of which will probably be celebrated in I9I2. At Easter their place is taken by White Arum Lilies, Richardia aethiopica, from the Cape, and other appropriate plants.

Among plants grown for the sake of their foliage are several species of Canna, often treated as bedding-plants in this country; the Labiates, Coleus thyrsoideus and others; Moschosma riparium; Cretan Dittany, Origanum dictamnus, well known to herbalists; the large-leaved Composites, Farfugium grande from China, and Humea elegans from Australia, both nearlyrelated to the Cineraria.

Other rare or noteworthy species are :

Abutilon lawitzii

Anigozanthus flavida

Azara gilliesii

Corosceia cotoneaster

Lilium sulphureum

Peucedanum fraxinifolium
Podalyria biflora

Polygala apopetala

Primula kewensis $x$

Thomasia quercifolia

Watsonia ardernei

\section{NOS. 5, 6, AND 7 STOVE-HOUSES (North Block)}

Look, here is the banana a-bearing of its fruit, And here you've got the plantain and the cocoa-nut to boot:

The coffee-plant in berry you also here may see, And likewise the prickly pear and the Ingy-rubber-tree,

The Ingy-rubber-tree.-Punch.

The north block of stove-houses and the corridor outside the east wall of the Garden, were erected in 1894 by Messrs. Boyd of Paisley.

They took the place of a range of glass-houses of $84 \mathrm{ft}$. in length, which were partly lean-to against the outside of the Garden wall, partly

* An eighteenth-century precursor of such a "Florist Feast" was "A Show of Carnations in the Town Hall, August 8, I 782." 
covered by an iron and glass ridge-and-furrow roof. Of these, No. 5 was originally a propagating-house, but Daubeny devoted it to Orchids. Nos. 6 and 7 were built in $185 \mathrm{I}$ : No. 6 for the Water-lilies as at present,

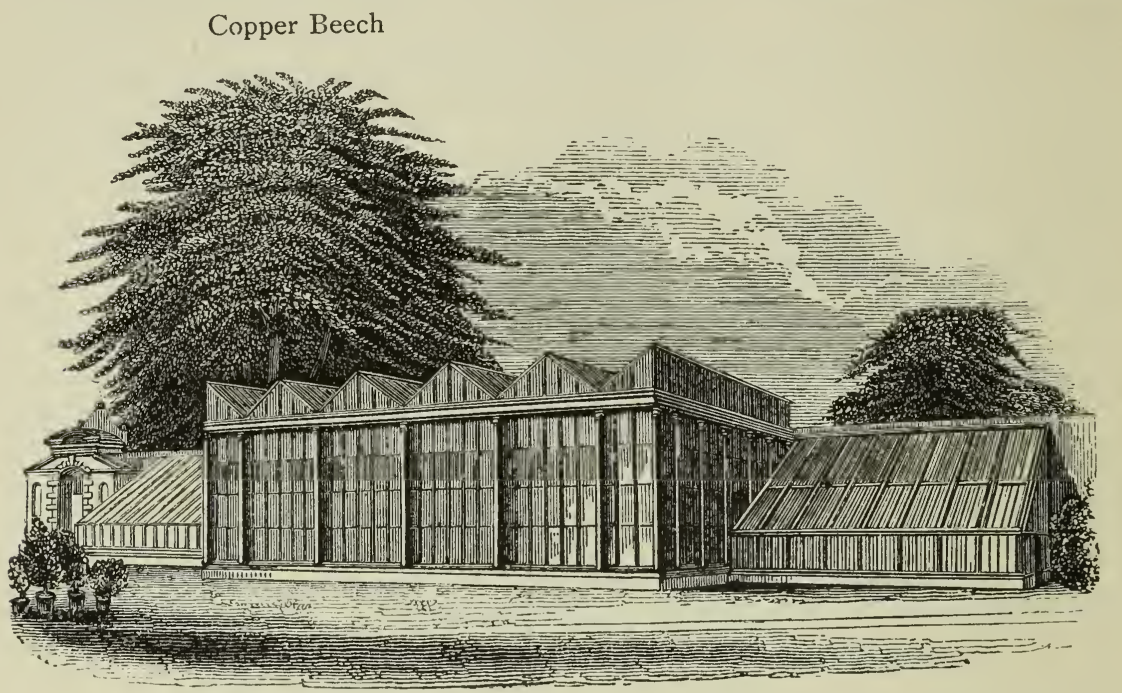

Economic, Victoria Lily, ANd Orchid Houses, 1851-94

and No. 7 to house the collection of Economic Plants useful in medicine or in the arts.

In the tank in the middle house the large Victoria Regia Waterlily was grown in $1853^{*}$ and subsequent years, but the room of this giant was found to be worth more than its company, and no one who sees the exquisite collection of Water-lilies now grown, will much regret its absence. This house was a particular object of pride to Dr. Daubeny, who, during a period of straitened finances, covenanted to keep it up out of his own pocket; and that this was no small matter is evident from the report of his successor, who stated that for many years the house and tank had been slowly but constantly sinking. The Jews' Burial Ground afforded no proper foundation.

\section{The North CORRIDOR}

Some handsome climbers, planted in the bed along the side of the corridor, are trained against the Garden wall. A

* Only four years after the Victoria Regia had flowered for the first time at Chatsworth, Nov. 8, 1849 . 
list of these in order from north to south is given on p. I45, but we may draw attention to Solanum wendlandii; and to Bougainvillea glabra, var. sanderiana, flowered in 1897 . The variegated variety of Arundo donax grows vigorously in the bed under the wall.

On the other side of the corridor, away from the wall, are the Acanthaceous Hexacentris coccinea, and two specimens of the India-rubber Tree, the Yam, Dioscorea macrura, Asparagus, and Vitus plerophora - a most instructive specimen, for the stem has been cut away quite a foot from the ground, down to which numerous adventitious roots have grown, which lie on the surface like a tangled coil of string. The pink aerial roots often exceed $12 \mathrm{ft}$. in length.

Cyperus, Begonia, and Streptocarpus are planted out in the border.

Of other Yams there are the Otaheite Potatoe, Dioscorea sativa, cultivated in India, and $D$. reticulata. 'The tubers contain much starch and may increase to a weight of $50 \mathrm{lb}$. They are nearly related to the Elephant's Foot grown in Green-house No. I 2.

Passiflora edulis yields a fruit like the Granadilla of tropical America, from which a preserve is made.

Ficus elastica, well known from pot specimens grown as ornamental plants, is one of the principal sources of indiarubber,* which exudes from its leaves and trunk as a semiliquid white juice, wherever an incision is made through the epidermis.

\section{No. 5. The Fern House}

The old collection of Tropical Ferns was contributed in great measure by James Atkins, Esq., of Northampton.

* Other sources of rubber are Hevea braziliensis or Siphonia elastica of Central America, one of the Euphorbiaceae; Castilloa elastica of Mexico (Artocarpaceae); Landolphia, Willughbeia, and Urceola, Apocynaceous plants from Malaya, Borneo, and Central Africa. Isonandra gutta (Palaquium giuta), Malaya, yields the well-known gátta pârcha. 
Owing to the small size of the house, the collection of Stove Ferns is strictly limited. Species which will stand a more temperate atmosphere are grown at the back of the Conservatory No. 4, where also are a few specimens of larger growth, such as the Tree Ferns of the Southern Hemisphere, Dicksonia and Alsophila.

Large examples of Davallia polyantha, and of D. elegans, will at once attract attention, and so will two fine specimens of Marattia cooperi.

In the Stag's-horn Fern, Platycerium alcicorne, the fertile fronds branch like a reindeer's horn, whilst the sterile ones form great green discs upon the tree on which it grows.

The Filmy Ferns are housed in a Wardian case in No. I 2 Green-house.

The collection includes:

Ord. 1. Hymenophyllaceae

Todea hymenophylloides

Trichomanes radicans-

var. albamense

var. cambricum

var. exsectum

var. luschnatianum

Ord. 2. Poly podiaceae

Fam. I. Davallieae

Davallia affinis

$\begin{array}{ll}, & \text { alpina } \\ , & \text { bullata } \\ " & \text { elegans } \\ , & \text { platyphylla } \\ , & \text { polyantha } \\ , & \text { tenuifolia veitchiana } \\ , & \text { wallichiana }\end{array}$

Fam. 2. Pterideae

Pteris argyrea

"flexuosa

", hirsuta
Ord. 2. Polypodiaceae (cont.)

Pteris marattiaefolia ,, mariesii

Adiantum bausei

$\begin{array}{ll}, & \text { cardiochlaena } \\ , & \text { concinnum latum } \\ , & \text { dolabriforme } \\ , & \text { formosum } \\ " & \text { grandis } \\ , & \text { hispidum } \\ , & \text { pecottei } \\ , & \text { pubescens } \\ , & \text { rhodophyllum } \\ , & \text { tenerum } \\ , & \text { trapeziforme }\end{array}$

Fam. 3. Asplenieae

Asplenium inequale

,, thelypteroides, var. cristatum
baziliensis

Lomaria gibba 
Ord. 2. Polypodiaceae (cont.)

Fam. 4. Aspidieae

Nephrodium chinense

$$
\text { , odoratum }
$$

, pallidum, var. cristatum

," proliferum

Polystichum cristatum, var. variegata

,, isus sinensis

Fam. 5. Polypodieae

Polypodium adnascens

$\begin{array}{ll},, & \text { aureum } \\ , & \text { glaucum } \\ ,, & \text { ixioides } \\ ,, & \text { pectinatum } \\ ,, & \text { pustulatum }\end{array}$

Gymnogramma chrysophylla
Ord. 2. Polypodiaceale (cont.)

Fam. 6. Acrosticheae

Platycerium aethiopicum

alcicorne

veitchii

Ord. 3. Cyatheaceae

Alsophila atrovirens

", truncata

Dicksonia culcita

Ord. 5. Schizaeaceae

Aneimia phyllitides

Lygodium japonicum

Ord. 6. OsmundaceaE

Osmunda japonica, var. corymbifera (in Greenhouse)

,, javanicum

Many tropical Selaginellas occupy the shelf on the south side of the house. Although all the living forms are plants of small size at the present time, yet in the geological past their near relations, the Lepidodendrons, filled the extensive swamps which have largely helped to form the coal measures.

Dr. Daubeny demonstrated the presence of a large percentage of alumina in the ashes of some of the species of Selaginella.

'The following are grown now, and those marked with a * were also in the collection in 1856 :

Selaginella albonitens

amoena
canaliculata
densa elegans
emiliana
grandis

S. lepidophylla *

S. nıartensii, Mexico*

S. patula

S. plumosa *

S. serpens
S. suberosa

S. victoria

S. viticulosa *

S. wallichiana *

S. watsoniana

Under the name S. lepidophylla, from Mexico there is a beautiful little plant possessing hygrometric properties. The fronds are arranged in a kind of rosette, and when dry are rolled inwards, so that the plant then resembles a ball. If 
in this condition it is placed in water, a large quantity of that liquid is absorbed, the fronds are unfolded, and the original form of the plant is restored.

The Club Mosses, Lysopodiaceae, are not always to be seen in the Garden, which is a pity, because they represent an ancient race in which the spores were all of one kind. The spore-bearing leaves are often clustered in cones: the minute spores form the familiar lycopodium powder.

\section{No. 6. The Water-Lily House}

The Water-lily House, in the middle of the block, measures about $\mathrm{I} 2$ yds. by ro yds.; the centre is occupied by the tank measuring 9 yds. by 7 yds., and is $4 \mathrm{ft}$. in depth.

During the months of June and July the exuberance of healthy vegetation in this house is calculated to give the visitor some idea of the rank luxuriance in the steamy vapours of a tropical swamp: but here, the leaf-forms, grown in complete shelter from wind, are more perfect.* Nor is the resemblance merely a superficial one, for if the gardeners who tend the water-plants were to omit to take a periodical dose of quinine, fever in a malignant form would be the penalty.

On entering, we are confronted by a plot of Papyrus growing in the well-ordered swamp, which has been arranged along the near border of the tank.

Papyrus antiquorum, now found in Europe only on the banks of the Anapo in Sicily, and in Africa high up the Nile above the cataracts, supplied the ancient Egyptians with material for their paper, which may easily be prepared by selecting some of the largest of the stems, and, after removing the epidermis, cutting the pith longitudinally in thin slices, and uniting the edges by gum-water, or any other adhesive liquid. Among the Egyptians, water from the Nile was said

* Illustrations of the interior have appeared in the Gardeners" Chronicle for 1885, p. 84 , and in the "Book of Gardening," 1900. 


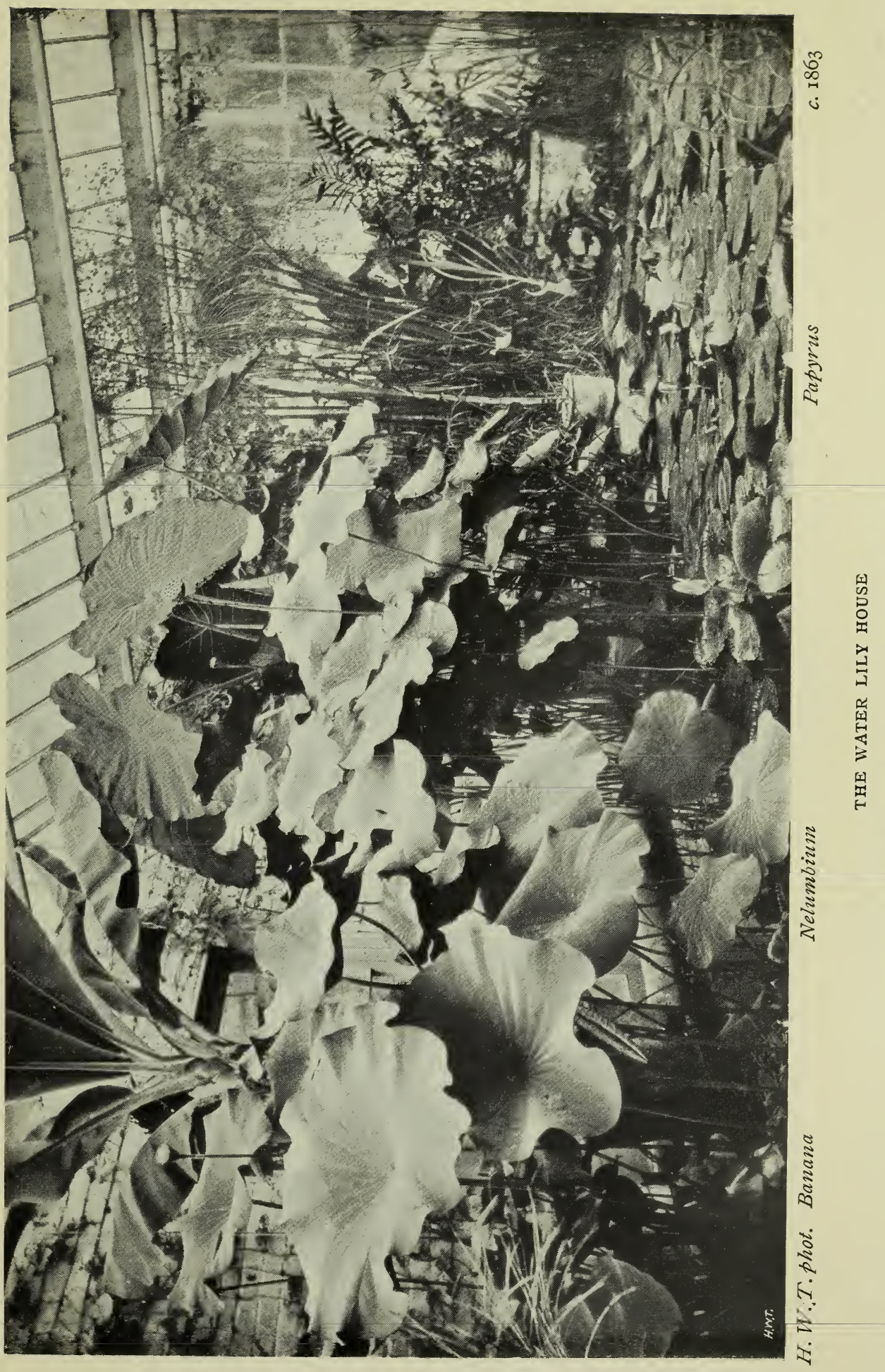



to have been employed for the purpose. In order to counteract the contraction which takes place in drying, similar slices are to be glued on across the grain of the former, after which the sheet produced, must be subjected to strong pressure.

Left of the Papyrus is a strong plant of Mariophyllum proserpinacioides.

Further to the right is a fine clump of Nelumbium speciosum, the Sacred Bean of Egypt, anciently cultivated in that country, but no longer found there, though common enough in various parts of the East Indies. Its leaves, which are orbicular, sometimes measure $2 \mathrm{ft}$. in diameter; and its handsome and fragrant flowers may exceed the size of ro in. The ancient Egyptians used the seeds, which are enclosed in a pepperbox-like fruit, as an article of food.

The Lotus is extensively cultivated by the Chinese, by whom the roots are highly valued as a vegetable.

Nelumbium luteum from Carolina, with pale yellow flowers, flowered freely in the first years of the house, circ. $185^{2}$.

At the corners of the tank, rising behind clumps of Cyperus, are small specimens of Plantains and Bananas. Musa paradisiaca is remarkable for its large oblong entire leaves, from the centre of which issues a spike of flowers disposed round a common axis, each group protected and covered over at first by a coloured bract, which afterwards drops off and thus allows the fruit to expand and ripen. This species, however, is too much checked in its growth by the dimensions of our house to yield fruit; but another, the $M$. cavendishii or dwarf Banana, which grows only to the height of $6 \mathrm{ft}$. or $8 \mathrm{ft}$., produces in most years large bunches of fruit, ${ }^{*}$ which are (or should be) eaten by the Vice-Chancellor, the President of Magdalen, and the Professor of Botany. M. cavendishii is a Chinese plant which has had an interesting cultural history, for it has now been widely distributed in the Pacific Islands. A specimen grown at Chatsworth was exported in a Wardian * Bananas ripened in the years $1888,1889,1891,1895,1897$, and 1903 . 
case to Samoa, whence in 1848 Mr. G. Pritchard distributed specimens to the Friendly and Fiji Islands in the Pacific (which were then stricken with famine), and with most successful result, since this dwarf Banana never fails to ripen its fruit. M. Wilsoni is also grown.

Along the margin of the water the Water Hyacinth, Eichhornia speciosa (Pontederia crassipes) from Guiana grows like a weed. It bore its pretty blue spikes of blossoms in I 898, and either it or another species has done so on many occasions since. It is distinguished by the swelling leaf-stalk, which, filled with air, gives the plant great buoyancy.

The vivid tints of the Water-lilies in the tank will next attract attention-indeed, from the month of June onwards they are the feature of the house. In Dr. Daubeny's time the Oxford Garden was noted for the excellence of its Waterlilies, and for the early successes of Mr. Baxter. The good reputation is being ably maintained by Mr. Baker, who is an acknowledged expert in their cultivation, and the author of the article thereon, in the "Book of Gardening." Several of the illustrations in that volume have been prepared from plants grown in our Garden.

The Egyptian Lotus, Nymphaea lotus, is a plant of much historical interest, the blossoms and buds of which figured much on the painted monuments of that country, and which probably suggested the form of the capitals on the columns of certain orders of Egyptian architecture.

In I 853 the collection of Water-lilies included Nymphaea stellata (coerulea) from Egypt, a very beautiful plant with large blue petals; $N$. cyanea and rubra (red), from the East Indies; dentata (white), from Sierra Leone: devoniensis, a free-flowering hybrid, raised at Chatsworth from rubra and dentata; odorata minor, a small fragrant species from N. America; micrantha from the river Gambia; and pygmaea, the smallest of the species known to us, a hardy species from China. The hybrid $N$. daubenyana ${ }^{\circ} \times(=N$ 
stellata $\times N$. micrantha ${ }^{*}$ ) originated in the Garden about $185 \mathrm{I}$, and for a long time held a place as the best of its class both for beauty and length of time of flowering. In colour it is pale blue, it has the scent of $N$. stellata, and produces bulbils like micrantha. Cabomba viridifolia and Euryale ferox have also been grown.

Among the newer forms are :

Nymphaea amazonum $\bullet$

$\begin{array}{ll}" & \text { ampla } \\ " & \text { blanda } \\ " & \text { columbiana } \times \\ " & \text { deaniana } \times \bullet \\ " & \text { flava }^{\circ} \\ & \text { gigantea, var. hudsoni- } \\ & \text { ana } \\ & \text { lotus, var. monstrosa }\end{array}$

Nymphaea mexicana ${ }^{\circ}$

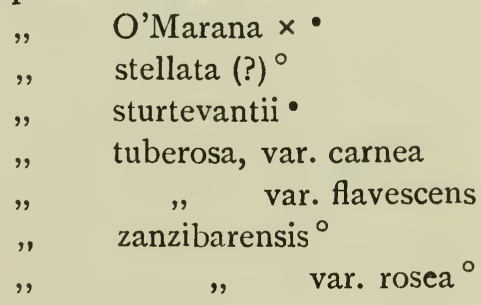

Some of these bloom by day, some by night, when the Garden is closed to the public. Several day-bloomers close petals and sink below the surface during the night. Dark spots indicate night-bloomers; light spots ${ }^{\circ}$ indicate day-bloomers.

Those virgin lilies, all the night

Bathing their beauties in the lake,

That they may rise more fresh and bright

When their beloved sun's awake.-MOORE.

Waterweeds of unusual size and form luxuriate in their appropriate quarters near the margin of the tank. The largest, Pistia stratiotes, grown here in former years, is common in the ponds of the West Indies, where its leaves float loosely on the surface of the water like green lettuces unattached to the soil. It is a constituent of the "sadd" which is so great an impediment to navigation on the Upper Nile.

* Baxter's hybrid has apparently escaped the notice of Caspary and Conrad (I905), but it is mentioned by Maxwell Masters, Gardeners' Chronicle, May 24, 1856. A few bulbils flowered in 1911. 
In another spot is confined the neat-growing Salvinia, forming a delicate mossy carpet floating on the surface of the water.

Water Plantains, Alismaceae, are represented by Limnocharis flava and emarginata and Echinodorus macrophyllum.

The pretty Hydrophyllaceous Plant, Hydrolea spinosa from Surinam, may also be seen in the tank, and in 1864 the Madagascar Lattice Leaf Plant, Ouvirandra fenestralis, was grown, and we have had it on several occasions since, but it requires running water for its healthy development. The leaves look as if they had undergone maceration, the interstices between the veins being open. 'The roots are cooked and eaten by the natives, who call it the Water Yam.

Two or three of the tropical Grasses of vigorous habit have occasionally been grown. One of these is the Sugar-cane, from whose closely jointed stem is extracted the saccharine juice, which we convert by boiling into syrup.

Another species of grass, which from its size might almost be mistaken for a palm, is the Bamboo, Bambusa arundinacea, a plant which in the tropics rises to the height of more than I oo ft. in a season, and at Kew has been measured to grow Io in. in twenty-four hours !

On the shelves next the glass will be noticed several beautiful members of the Lily Order.

Most noteworthy, perhaps, are the singular flowers of the plants related to Gloriosa superba, a name assigned by Linnaeus himself, who likened the scarlet undulated segments of its corolla to so many tongues of flame. Its long style is very singular, as it points horizontally, and appears, where it springs from the ovary, as if broken at its base.

$G$. abyssinica and $G$. rothschildiana have both flowered in recent years.

To the Pine-Apple Order, Bromeliaceae, belong Billbergia, Aechmea, Karatas, Ortgiesia, and Pitcairnia; also 
the epiphytic Tillandsia-which, like tropical Orchids, live on trees, and often have the bases of the leaves filled with water, which has proved serviceable to men and animals. $T$. acaulis zebrina and $T$. splendens are remarkable for their singular transversely-streaked foliage.

To this order belong :

Aechmea coelestis

$" \quad$ coerulescens

" conglomerata

" distacantha, var.

Schumbergeri

exudans

pineliana

Guzmannia devansayana

Karatas carolinae

,$\quad$ innocentii variegata

" johannis

" makoyana

" princeps
Karatas rutilans

" tristis

Ortgiesia legrelliana

$" \quad$ tillandsioides

Quesnelia cayennensis

" wittmackiana

Rhodostachys pitcairniaefolia

Tillandsia dianthoidea

$\begin{array}{ll}" & \text { fenestralis } \\ " & \text { lindeni, var. anceps } \\ " & \text { morreni } \\ " & \text { parabaica } \\ " & \text { tessellata }\end{array}$

Among the other pot plants are some fine Caladiums, and several members of the Scitamineae or Ginger Order, among which Hedychium coronarium is related to H. spicatum, the source of abir, the scented powder of the Hindus.

\section{No. 7. The Small Stove-house}

On entering the Small Stove-house the first plants which attract the visitor's eye are the grotesque Pitcher Plants, of which we have a good collection in hanging baskets. Each of the leaves terminates in a pitcher, having a lid at top. These pitchers contain a considerable quantity of fluid which, as Daubeny rightly argued, is secreted by the plant, and is not necessarily derived from without. By means of this pitcherliquid, the plant is enabled to vary its diet by adding an occasional fly to its menu.

Professor Vines has been able to show that in the case 
of Nepenthes mastersiana proteolytic digestion is due to an enzyme, "nepenthin," and not to a bacterium ("Annals of Botany," I897). The species grown include $N$. curtisii, dicksoniana, mixta, and tiveyi-several presented by Messrs. Veitch of Chelsea.

Overhead is trained a fine specimen of a Dutchman's Pipe, Aristolochia elegans, from Brazil. Here the pitchershaped flowers may be contrasted with the leaf-pitchers of Nepenthes.

The leaves of Oxalis sensitiva, which is occasionally exhibited in this house, move, when touched, like those of the Sensitive Plant.

On the stands will be seen some fine species of Caladium and Pothos, remarkable for their large spreading and often richly coloured leaves. An allied species, Dieffenbachia seguina, is remarkable for its acidity; if chewed, it causes the tongue to swell so as to destroy for a time the power of speech, and is hence popularly named the Dumb Cane.

The Marantu arundinacea is interesting as the plant which yields the West Indian arrowroot, whilst $M$. bicolor, lineata alba, vittata, and zebrina (now Calathea zebrina) are grown for their ornamental foliage.

Allied to the MarantaceaE, which yield a pure and delicate kind of starch, are the Gingers, ZingIBERACEAE (Scitamineae), noted for their hot, stimulating principle. Among them are classed Globba (bulbifera, marantina); Hedychium horsfieldii, and Gardnerianum, remarkable for its large head of fragrant flowers; Kaempferia pandurata (ethelae, natalensis, rotunda, and undulata); Alpinia officinarum the Galangal; Curcuma bakeri, a genus which supplies both Turmeric and East Indian arrowroot; Amomum, a Cardamoms genus; and Costus fissiligulatus and Burbidgea schizocheila. All are in one or other of the Stove-houses. Mantisia saltatoria, the "Dancing Girls" grown in the sixties, is, unfortunately, no longer with us, 
Peppers are grown both in the Small Stove and in the Palm House. Piper nigrum is an Indian climber, which yields both black and white Pepper; the former being the unripe berries, the latter the ripe fruit, from which the rind has been removed after soaking in water. Nearly half of our imported pepper, about 9,000,000 lb., comes from the Straits Settlements.

P. methysticum has a horse-radish-like root, cultivated in the Pacific Islands for the preparation of kava, a slightly narcotic liquid, which tastes like soapsuds and is good for quenching thirst.

P. porphyrophyllum and Peperomia diaphanoides, metallica, and resedaeflora are all grown.

Klugia notoniana (Gesneraceae) was brought by Professor Farmer from Ceylon in 1892 .

A plant of exceptional interest is the Rubiaceous Myrmecodia beccarii, which lives in Malaya, in association with a standing army of ants, which it provides with adequate lodging in return for defensive services. Another instance of such a symbiosis is afforded by the Buckthorn Acacia growing in the Palm House, but in that case the plant provides board as well, for its defenders.

The following Stove plants of economic importance have been grown in one or other of the houses, and if they are not in the collection at any one time, their places are probably filled by plants of as great, if not greater, interest :

Anona muricata (Anonaceae), bearing the succulent West Indian fruit called the Sour Sop.

Bombax malabaricum (Malvaceae), an Indian large softwooded tree of no great worth. From its fibrous bark, ropes can be made, and the gummy exudations are employed in Indian medicine. The silk cotton covering the seeds is used for stuffing cushions.

Cinnamodendron rubrum from Brazil has a bark re- 
sembling in its agreeable odour the true Cinnamon, which, however, comes from Cinnamomum, a Cingalese Lauraceous tree. We have found many Cinnamonleaves as fossils in the Bournemouth cliffs, an indication that that health resort has enjoyed an even warmer climate than at present.

Several species of Indigofera besides I. tinitoria (Leguminoseae) are used in the preparation of the dye. The plants are soaked and beaten in vats until their green colouring matter has become oxidised into insoluble blue indigotin which passes into suspension in the water. After settling and boiling, the blue mud is dried in the sun. In I909, $\mathcal{I}^{\mathrm{I}} 30,000$ worth of this dye-stuff was imported, and $\mathcal{I}_{\mathrm{r}} 64,000$ worth was synthesised by manufacturing chemists.

Pimenta officinalis (Myrtaceae) is the source of allspice or Jamaica pepper, and from the leaves of $P$. acris the American scent, oil of bay, is obtained, which is now well known in the bay rum of hairdressers' shops.

The unopened flower-buds of Eugenia carophyllata are green when newly gathered, but when dried turn brown and are known as cloves.

Pogostemon patchouli is an Indian Labiate. Its aromatic oil has been less in favour as a scent with the fair sex than was formerly the case.

Tamarindus indica (Leguminoseae) pods yield a pulp with laxative properties. Cooling drinks are prepared from tamarinds in hot countries.

Mucuna pruriens is a less desirable climbing Leguminous plant from the Indies, both East and West. The stiff hairs readily enter the skin, and cause an itching so intolerable that the plant is known by the vulgar name of Cow-itch. 
List of other Stove Plants which have been Grown in the Houses Within the LAST FeW Years

(See also lists on p. 120)

Acalypha godseffiana

" hamiltoniana

hispida

Achimenes pedunculata

Aphloia mauritiana

Biophytum proliferum

Brexia madagascariensis

Browallia speciosa

Callicoma serratifolia

Calvoa orientalis

Campelia zanonia

Cardiospermum halicacabum (annual)

Cephalotus follicularis

Chirita fauriei

Combretum aculeatum

Corynocarpus laevigatus

Cyrtanthus spiralis

Deherainia smaragdina

Elaeodendron orientale

Eriocnema sanderae $x$

Erythroxylon coca

Galphimia glauca

Gladiolus buettneri

Glycosmis pentaphylla

Gravesia guttata

Haemanthus kalbreyeri

Hamelia patens

katherinae

" lindeni

Heliconia sanderi

Hibiscus mesnyi

Hippeastrum stylosum

Juanulloa parasitica

Kniphofia aloides var. praecox "northiae

Ledenbergia rosea aenea

Leea micholitzi

Lindenbergia grandiflora

Manettia cordifolia luteo-rubra

Marcgravia umbellata

Meconopsis integrifolia

"racemosa
Meconopsis sinuata

Medinilla magnifica

Olyra floribunda

Palisota barteri

„, bracteosa

, maclaudi

Panax balfourii

Passiflora pruinosa

Pentarhaphia longiflora reticulata

Phyllarthron bojeranum

Physostigma venenosum

Pinguicula caudata

Pitcairnia altensteinii

, andreana

, bromeliaefolia var. platyphylla

Pithecoctenium aubletii

Pleuropetalum costaricense

Pollia condensata

Portulacaria afra

Psychotria jasminiflora

Rhytidophyllum tomentosum

Richardia elliottiana

Royena lucida pentlandii

Sandersonia aurantiaca

Scutellaria ventenatii

Sinningia (Stenogastra) concinna

Solanum commersoni

, rantonnettii

Stenandrium lindeni

Stigmaphyllon ciliatum

Susum malayanum

Tacca artocarpifolia

" cristata

Tacsonia militaris $x$

Theobroma cacao

[Tradescantia reginae]

Tulbagia acutiloba

Turnera ulmifolia

Vangueria madagascariensis

Whitfieldia laterita 


\section{NOS. 8, 9, AND Io GLASS-HOUSES}

\section{(South Block)}

The south block of glass-houses and their corridor of communication leading to the potting-shed were erected by Messrs. Boyd in May to November, I893. Nos. 8 and 9 adjoin and measure Io yds. by 1o yds. and Io yds. by 7 yds., respectively. No. Io, the Succulent House, is intermediate in size and is only connected with the other two by the corridor.

They stand on the site of a corresponding range of three houses constructed in 1852 to receive the stove plants rendered houseless when the old central conservatory on the east side of the Danby Gate was altered to receive the Fielding Herbarium, presented to the University in that year. In Dr. Daubeny's time a stove-house for palms was flanked by a fernery on the north, and by a seed-room and stoke-house on the south.

\section{The South Corridor}

On both sides of the walk are planted some interesting shrubs and climbing plants, of which a fuller list is given on p. 145. Among the more noteworthy are several large Fuchsias and large plants of Salvia bethelii, Reinwardtia trigynum, Justicia carnea, and Jasminum primulinum. Jasminum sambac yields a strongly scented oil, the mohle of the Hindus, and belongs to the same natural order as the Olive and the Ash. As with many other strongly scented flowers, the odour is more apparent in the evening when breathed

From timid jasmin buds, that keep

Their odour to themselves all day,

But when the sun-light dies away

Let the delicious secret out

To every breeze that roams about.-Lalla Rookh.

The wax-like honey-laden flowers of Hoya carnosa are favourites alike with man and bees ; the latter, in some places, satiate themselves so completely as to be unable to fly away. 

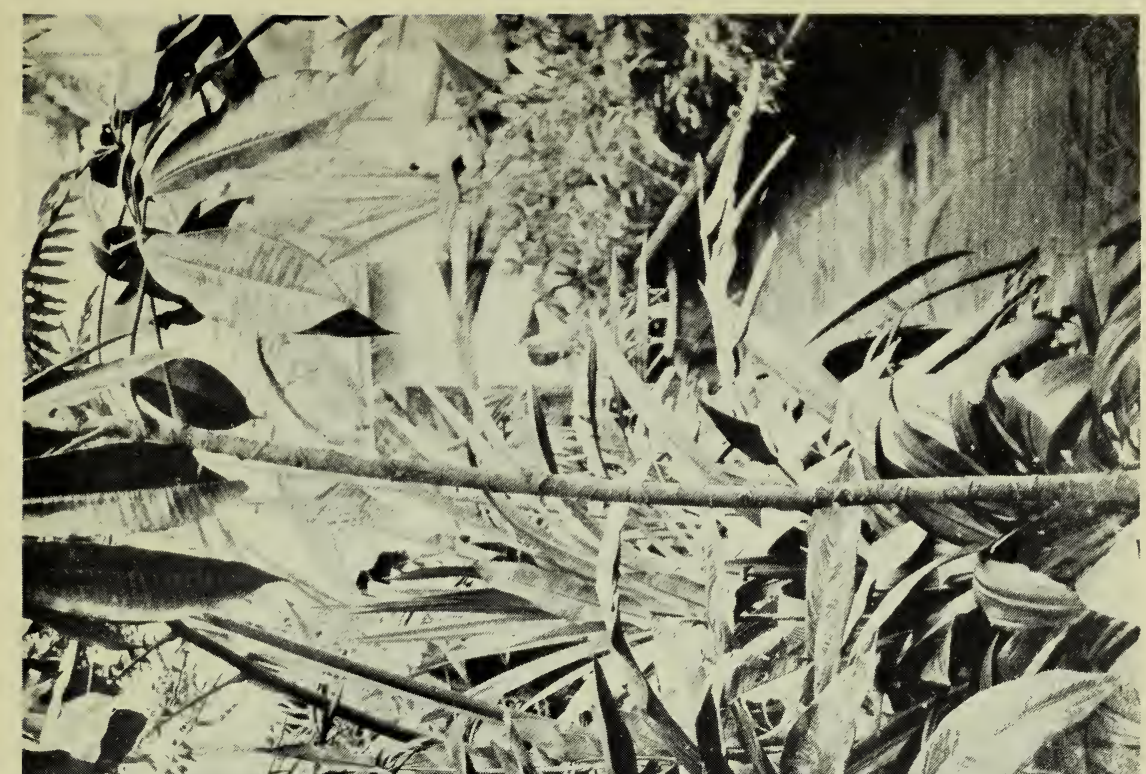

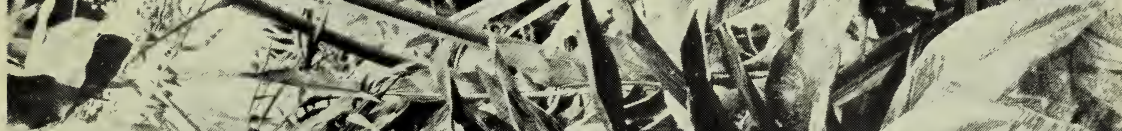
I

W n

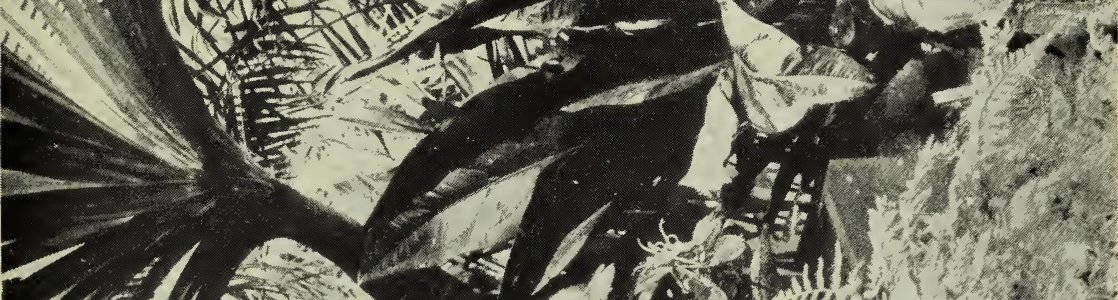

Yla - 15.4 .

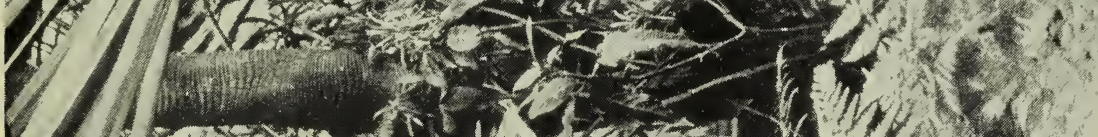

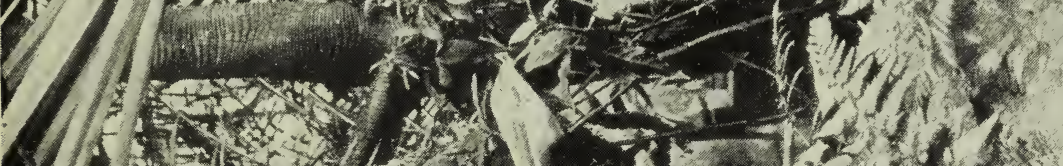

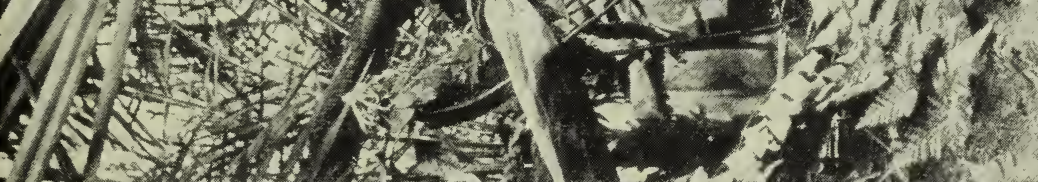

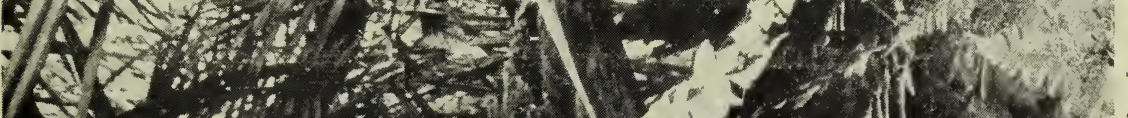
L.

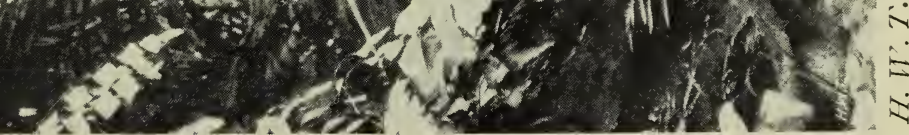





\section{No. 8. The Palm House}

Although the dimensions of the Palm House are not such as to admit of those magnificent examples of tropical vegetation which figure in some public and private collections, yet amongst its contents are specimens which may serve to convey some idea of the mode of growth and habits of that noble tribe of plants, the Monarchs, as Von Martius calls them, of the Kingdom of Nature to which they belong.

Some Palms which will endure a cooler temperature are seen in the Conservatory-where examples of the Fan Palm and others are exhibited. A moist soil is a necessity for the well-being of palms-indeed, in their native habitat they are often to be seen standing in water. A Date Palm cannot have too much; the roots, indeed, show a remarkable resemblance to parts of aquatic plants, in being full of gas spaces, ${ }^{*}$ and similar spaces have even been found in the stems of fossil Cretaceous Palms.

Palms are classified in six tribes by Hooker :

i. Areceae, including Areca catechu, the Betel-nut Palm, the chewing of which gives a fragrance to the breath and a red hue to the lips and mouth; $A$. glandiformis; Pinanga kuhlii; Kentia sanderiana; the Australian Archontophoenix cunninghamia, commonly known as Seaforthia elegans in this country; Dictyosperma fibrosum; Deckenia nobilis; Howea fosteriana (Orchid House); Bentinckia nicobarica.

ii. Phoenix is the only genus of the second tribe. The Date Palm, dactylifera, is interesting because in the most remote antiquity it was cultivated, and conveyed to those early "arboriculturists" some dim notion of the distinction of sexes amongst plants. Phoenicia was named after it, and

* Drabble, "Roots of Palms," "Trans. Linn. Soc," 2nd series, vi. p. 427 . 
Bethany $=$ house of dates. P. reclinata from Natal is in the Orchid House.

iii. Corypheae, including Sabal, Corypha, Chamaerops, Copernicia, Thrinax. Chamaerops humilis, the hardiest of all our palms and indigenous to the south of Europe, is housed in the Conservatory.

In the Palm House are the Carnauba or Brazilian Wax Palm; Copernicia cerifera, from which candles may be made; Pritchardia pacifica; Livistona inermis; Thrinax morrisii, a dwarf palm of Anguilla; and Thrinax parviftora, of which a small specimen was brought from Cuba by Dr. Daubeny in 1838 (G. C. 1864).

iv. Lepidocaryeae. Calamus scipionum produces the Malacca canes used for walking-sticks and rods for chimney-sweeping.

v. Borassus, the Palmyra Palm, is the type of the fifth tribe to which the Coco de Mer belongs.

vi. Cocoinea e, represented by Cocos flexuosa.

The common Cocoa-nut Palm, Cocos nucifera, is not always grown in the Garden. It is of varied and great utility, as it supplies the native of the tropics with thatch for his houses; with the materials for matting, brooms, and timber; with oil, expressed from the dried kernel or copra; with food for both man and beast; with a liquor (toddy) capable of fermentation, and convertible into the ardent spirit known as arrack; and with fibres suited as a material for preparing coir hawsers. Cocoa-nut oil is used in the manufacture of composite candles, and some 8,000 tons are annually imported into this country.

To the Order of Screw Pines belongs Pandanus panderi.

The Dragon Trees are the largest of the members of the Order of Lilies. One Dracaena draco grew to the colossal 
size of $5 \mathrm{I} \mathrm{ft}$. in circumference in the island of Teneriffe. Several species have been grown in the Palm House in recent years, ${ }^{*}$ as well as the nearly allied Cordyline fragrans.

A link with the remote geological past is afforded by the Sago Palms or Cycads, which are closely related to fossil plants which flourished in the Mesozoic Period, and afford us living pictures of a part of that bygone vegetation. While retaining very primitive characters, the extinct Bennettiteae are thought to have resembled Angiosperms in having conspicuous flowers, and in having fruits which enclosed exalbuminous seeds.

Modern Cycads inhabit the warmer regions of the continents, and reach a great size and age.

Australian Cycads grow $60 \mathrm{ft}$. high, and Dioon edule is said to live for $\mathrm{r}, 000$ years in Mexico. They are unique among flowering plants, except the Ginkgo, in that the male cells are motile like those of the Ferns.

Cycas revoluta yields a sort of sago from its pith, though the sago of commerce is usually obtained from the allied C. circinalis. Another kind of arrowroot or sago is got from Dioon edule.

Several species of Zamia (integrifolia, lindeni, loddigesii (1890)) have been grown, and it was with the trunks of these plants that the fossils, called "petrified birds'-nests," found in Portland building stone, were first identified.

Bowenia spectabilis, var. serrulata, flowered in 1899 , and Encephalartos horridus produced a cone in 1895 .

The remarkable Stangeria paradoxa of Natal, in its habit and veined fern-like leaves, is unlike many other Cycads, and was at first described as a Fern, Lomaria.

Among the Aroids the large Amorphophallus campanulata and rivieri are conspicuous; the former flowered in 1889 and

* Dracaena godseffiana

Dracaena surculosa

,$\quad$ rumphii
,$\quad$ sanderiana

, thalioides 
again in 1892. The leaves of the gigantic $A$. titanum are said to grow to a circumference of $45 \mathrm{ft}$. (Beccari). The allied Hydrosme rivieri is also represented. Of the other genera we have Spathiphyllum patinii; Nephthytis liberica; brightflowered Anthuriums, often with the Orchids in No.9; and several fine-foliaged Caladiums and Colocasias* scattered about among the other stove plants. In the East, Aroid roots, "cocoes," are a useful food, and biscuits are prepared from Aroid flour.

The Sensitive Plant has been grown at Oxford as a "wonder and a curiosity" ever since I654, when John Evelyn saw it there. Some forty years on, Celia Fiennes mentioned it again in her diary: "There is also $y^{\mathrm{e}}$ sensible plant, take but a Leafe between finger and thumb and squeeze it and it immediately Curles up together as if pained, and after some tyme opens abroad again, it looks in Coullour like a filbert Leafe, but much narrower and long. There is also the humble plant that grows on a long slender Stalke and do but strike it, it falls flatt on $y^{\mathrm{e}}$ ground, stalke and all, and after some tyme revives againe and Stands up, but these are nice plants and are kept mostly under Glass's, $y^{\mathbf{e}}$ aire being too rough for them."

And it was perhaps in our Oxford Garden that an undergraduate contemporary of Dr. Daubeny, and like him an enthusiastic chemist, may have first become acquainted with

* In recent years have been grown :

Aglaonema treubii

Anchomanes hookeri

Anthurium hookeri (9)

Arisaema ringens

Caladium albanense

$$
\begin{array}{ll}
, \quad & \text { speciosa } \\
, \quad & \text { venosa }
\end{array}
$$

Colocasia sanderiana
Homalonema rubescens (6)

Hydrosme rivieri (7)

Nephthytis liberica

Schismatoglottis neoguineensis (7)

Spathiphyllum patinii

Typhonium gigantea

Xanthosoma lindeni (6)

The numbers refer to the houses where the plants were exhibited. 
the peculiar properties of that plant, the name of which he has immortalised as the title of perhaps the most glowing description of a flower-garden in our literature*; or, again that the same interesting plant was made the subject of a pictorial simile by A. C. Collins in the beautiful picture "Convent Thoughts," in the University Galleries. On being touched gently, the paired leaflets close upward. On rougher treatment the pinnae fold, and eventually the whole leaf sinks down and hangs as if withered. But after an interval the leaves rise and the leaflets open once more.

Equally wonderful, though in quite a different way, is the Acacia sphaerocephala. It is provided with organs by which, in a state of nature, it is enabled to keep a mercenary army, an army of ants, for its own protection. The large stipular thorns are hollow, and serve as sentry-boxes or dwellingplaces for the ants, which are thus not only housed, but are also fed by the plant, on Belt's corpuscles, ovoid structures, rich in proteids, which are developed at the ends of the leaflets, and are so loosely attached as to be easily plucked by the hungry soldiers. Similar food-bodies are grown by the Imbauba or Trumpet Tree (Cecropia), and by Thunbergia, plants belonging to totally different natural orders, but having similar close relations with protective ants.

Amongst the shrubs or trees which have been grown on account of the valuable articles of commerce they yield, we may mention the following plants :

Coffee, the seeds of Coffea liberica (or C. arabica), now grown in many tropical countries. Our total imports exceed $£^{2,500,000}$ in value and 46,000 tons in weight. One of the earlier papers of Dillenius, written before he came to Oxford, was "De Cahve arabico."

Cocoa or chocolate comes from a small neotropical tree,

* "The Sensitive Plant" was written in the garden of Lady Mountcashell, less than ten years after Shelley had been sent down from Oxford. 
which is now also cultivated in Ceylon, Theobroma Cacao. Our home consumption exceeds $46,000,000 \mathrm{lb}$. The Cocoatree belongs to the Sterculia Order, and must not be confounded with Erythroxylon coca (of the Flax Order), the leaves of which, in virtue of the cocaine they contain, when chewed, "lessen desire for food and enable the chewer to undergo an enormous amount of fatigue from an increase of nervous energy."

The large Red Guava, Psidium guajava, var. pomiferum, belongs to the Order Myrtaceae. Guava jelly comes from the West Indies.

Carludovica (Order Cyclanthaceae) is a neotropical genus worthy of notice, as being the source of the "straw" used for making Panama hats, which range in price from Is. $6 d$. to over $£_{20}$ apiece! $C$. latifolia and plicata are grown.

Several of the following rubber-yielding plants may also be seen in this house :

Funtumia elastica, the source of silk rubber, a most valuable product of $W$. Africa, which may perhaps be found suitable for growth in Uganda.

Landolphia klainei is the principal rubber-yielding climber of the Gaboon region. Related to it are Willughbeia and Urceola. All are Apocynaceae.

Hancornia speciosa is the source of over $1,500,000 \mathrm{lb}$. of Pernambuco rubber every year.

Hevea brasiliensis (Siphonia elastica) is another tree which is frequently mentioned in the prospectuses of the rubber companies. It is a Euphorbiaceous plant.

The Mexican Castilloa elastica is one of the Artocarpeae; and lastly, Isonandra gutta, a tree of $70 \mathrm{ft}$. in height, and $3 \mathrm{ft}$. or $4 \mathrm{ft}$. in diameter, yields the well-known gátta pârcha.

Ficus elastica may be seen in the North Corridor.

There is sometimes to be seen a small specimen of the Banyan, Ficus indica, or Urostigma benghalense, celebrated by 
our greatest poet, which, by sending iforth shoots from its branches, contrives to spread over so large an extent of ground that 7,000 persons, it is said, have been sheltered under a single tree. One near Poona had a crown of more than 500 yds. in circumference in I882 (Engler), and another on the banks of the Nerbuddah has at least 320 large trunks and 3,000 small ones (Forbes) -

Spreading so broad and long, that in the ground, The bended twigs take root, and daughters grow About their mother-tree, a pillared shade

High over-arched, and echoing walks between.

Ficus pandanus, growing in this house, has leaves shaped like those of an oak, but they may measure $\mathrm{I} \mathrm{ft}$. across.

Ficus religiosa, the Sacred Bo or Pepul Tree, is remarkable for the tail-like points at the tips of its leaves, which are converted, by a kind of maceration in water, and subsequent vanishing, into a sort of paper, upon which the Chinese make drawings. One Sacred Bo Tree growing at Anarajapoora is stated to be the oldest historical tree in the world, for it was planted in 288 B.c. "The Buddhist priests object to lop it with any weapon, and only distribute to pilgrims the leaves which fall naturally to the ground." $F$. benjamina and $F$. roxburgii, remarkable for its large circular leaves, are also grown.

Another curious plant of this family is the Bread-fruit Tree, Artocarpus incisa of the Pacific Islands. Its fruit resembles a gigantic Mulberry; it is a compound fruit, sorosis, formed from flowers densely packed round a common axis It is as large as a child's head, and is commonly baked with hot stones.

Another curiosity is the Dorstenia draksana, which bears remarkable inflorescences. 
The following plants were also growing in the Palm House in June, I9I I :

Acidanthera aequinoctialis

Albuca nelsoni

Aphelandra grandiflora

Aplopappus eriocarpus

Ariopsis peltata

Aristolochiagigas, v.sturtevantii

Atalanta buxifolia

Barnadesia rosea

Bauhinia candicans

Beaumontia grandiflora

Billbergia decora

, euphemia

", liboniana

,, moreli

" speciosa

, vittata-bakeri $x$

Bougainvillea glabra

Brillantaisia palisotii

Bryophyllum proliferum

Cadia purpurea

Calodendron capense

Centropogon lucyanus

Clerodendron aculeatum

Clitoria

Cochliostema odoratissimum

Cola acuminata

Columnea rutilans

Combretum aculeatum

,, purpureum
Cordyline fragrans

Cryptostegia grandiflora

Dichorisandra discolor

Episcia punctata

Evodia elegans

Fallugia paradoxa

Francisca eximia

Hemigraphis repanda

Heritiera macrophylla

Hibiscus rosea sinensis

Justicia ventricosa

Mammea americana

Mascarenhasia

Monodora myristica (nutmeg)

Monstera delicosa

Musa wilsoni

Peristrophe speciosa

Phyllanthus retusa

Piper belle

,, nigrum

Pollia condensata

Pothos acaulis

Procris frutescens

Ruellia moena

Russelia juncea

Salvadora persica

Sanchesia spectabilis

Sarcocephalus esculenta

Senecio ghiesbrightii

Talinum indicum

Thunbergia erecta

Xanthochymus pictorius

No. 9. The Orchid House

The wing which flanks the Palm House to the south is designed for the tropical Orchidaceae, which arrest our attention whether we regard the gorgeousness of their flowers, the 
singularity of their forms, the causes which have produced such bizarre shapes, or the inaccessibility of their habitat on the branches of living trees.

The fragrance of one, Vanilla planifolia, is frequently brought to our recollection by chocolate-creams and flavoured confectionery, but the others do not yield much of value. Their worth is in themselves, and no plants of a purely ornamental character are more popular with wealthy amateurs, and the prices given for many, run into hundreds of pounds.

To the botanist they are of interest, because in spite of their high differentiation and wonderful mechanisms to assist cross-fertilisation by insects, their flowers are modified in the number of stamens, which are reduced to two or even to one only, as well as in the peculiar condition of their seeds, which germinate with difficulty unless the conditions be just right.

The epiphytic species are grown in fibre in open pots or in wooden baskets slung from the roof. In a state of nature their "air roots" are disposed so as to be wetted by rain or to collect dew from the moist warm atmosphere they love. In a green-house the conditions of a tropical rain-forest may be well imitated by dipping the epiphyte into a bucket of warm water.

On the north side of the house is a collection of Terrestrial Orchids, principally Lady's Slippers, Cypripedium, which are generally in blossom during the later winter months :

Cypripedium :

$\begin{array}{ll}\text { almum } & \text { exul } \\ \text { argus } & \text { godefroyae } \\ \text { barbatum } & \text { grande } \\ \text { bellatulum } & \text { haynaldianum } \\ \text { callosum } & \text { hirsutissimum } \\ \text { cardinale } & \text { insigne } \\ \text { caudatum } & \text {, var. Maulei } \\ \text { chamberlainianum } & \text { laurenceanum } \\ \text { charlesworthii } & \text { leeanum } \\ \text { curtisii } & \text { oenanthum } \\ \text { dautherii } & \text { parishii } \\ \text { elliottianum } & \text { rothschildianum }\end{array}$

sallierii aureum $x$ sanderianum selligerum spicerianum stonei superbiens venustum vexillarium superbum $\times$ wallertianum williamsianum $x$ williamsonianum 
The following list includes the more interesting Orchids which have flowered, or have been recently received:

Acanthophippium bicolor

Acropera loddigesii

Ada aurantiaca

Adenium obesum

Aenanthus leonis

Aerides sanderianum

Angraecum articulatum

, humblotii

, modestum

" sesquipedale

Brasso-Laelia digbyano-purpurata $x$

Catasetum bungerothi

, macrocarpum

Cattleya gaskelliana

$$
\begin{array}{ll}
" \quad \text { gigas } \\
" \quad \text { trianae } \\
" \quad \text { Victoriae Reginae }
\end{array}
$$

Chysis Chelsoni

Cirrhopetalum sp. (?)

Coelogyne dayana

$$
, \quad \text { lentiginosa }
$$

Cymbidium giganteum

Cynoches chlorochilum (Swanneck Orchid)

Cyperorchis Mastersii

Cyrtopodium macranthum

Dendrobium aggregatum clavatum crassinode cretaceum densiflorum devonianum dixanthum falconeri farmeri fimbriatum Gibsoni
Dendrobium glomeratum

$\begin{array}{ll}, & \text { gratiosissimum } \\ " & \text { loddigesii } \\ , & \text { nobile } \\ " & \text { Phalaenopsis } \\ " & \text { primulinum } \\ " & \text { rosea } \\ " & \text { suavissimum } \\ & \text { wardianum }\end{array}$

Dia-Laelia Veitchii $x$ Dichaea picta

Disa grandiflora

Epidendrum boandii

$\begin{array}{ll}, \quad & \text { fournerianum } \\ , & \text { imschootianum } \\ & \text { nemorale }\end{array}$

Hexadesmia fasciculata

Laelia anceps

$\begin{array}{ll}" & \text { cinna-brosa } x \\ " & \text { flava } \\ " & \text { ithone } \\ " & \text { latona } x \\ " & \text { Novelty } \\ " & \text { olivia } \\ , & \text { Pacuvia } \times\end{array}$

Laelio-Cattleya $\times$ canhamiana

$$
\begin{aligned}
& \times \text { decia } \\
& \times \text { eudora } \\
& \times \text { haroldiana } \\
& \times \text { hippolyta } \\
& \text { Homer } \times \\
& \times \text { pallas } \\
& \times \text { picamus } \\
& \times \text { remula } \\
& \times \text { statteriana } \\
& \text { Tenos } \times \\
& \times \text { Terentia } \\
& \times \text { Zephyra }
\end{aligned}
$$

Masdevallia Shuttleworthii 
Masdevallia Wallisii

Maxillaria sanderiana ,$\quad$ tenuifolia

Miltonia russelliana

Odontoglossum bictonense

Oncidium candidum citrosmum

$\begin{array}{ll}, & \text { gravesianum } \\ , & \text { harrisonii } \\ , & \text { jonesianum } \\ , & \text { Lanceanum } \\ , & \text { Papilio } \\ , & \text { sarcodes } \\ , & \text { sphacellatum } \\ , & \text { splendidum }\end{array}$

Oncidium tigrinum

, uniflorum

, varicosum

Ornithidium densum

Peristeria elata

Phaius grandifolius Humblotii Wallichii

Platyclinis glumacea

Sophronitis grandiflora

Stanhopea Bucephalus

$$
\text { , graveolens }
$$$$
\text { , oculata }
$$

Stenoglottis longifolia

Tetramicra rigida

Vanda amesiana

In the centre of the house are the showy Aroid, Anthurium scherzerianum, and its varieties, Araucaria brasiliana, Clerodendron balfourii, and Gloxinias and Begonias in their season. And among other plants we notice :

Acacia sphaerocephala

Acalypha godseffiana

Aeschynanthus lobbianus

Araucaria brasiliensis

Begonia argynea

Biophytum proliferum

Ceropegia woodii

Cordyline fruticosa
Haemanthus lindenii

Hibiscus solandra, var. grandiflorus

Howea fosteriana

Maranta massangeana

Phoenix reclinata

Saintpaulia ionantha

Vallesia cymbiforme

\section{No. Io. The Cactus or Succulent House}

"A collection which is probably hardly second to any in England."PROF. LAWSON in 1876.

In the relatively dry atmosphere of this house live the Aloes, the Cactuses, the leafless and poisonous Euphorbias, and other succulent plants, which in their struggle to preserve their stores of water from drying up, and eventually from thirsty quadrupeds, have sometimes evolved such uncouth and misshapen swollen forms as to present perhaps the widest 
departure from normal structure which is to be seen among the flowering plants. The majority come from the hot desert regions of the New World: their leaves are reduced to sharp dry spines of defence, and their green stems often look like fleshy leaves, but are more watertight than ordinary leaves.

The Opuntias or Nopals yield Prickly Pears, much eaten in S. Italy and in warm countries under the name of Fiche d'India, and their stems are used for making most effective fences. The Opuntia coccinellifer or Nopal is largely cultivated as the food-plant of a parasite, the cochineal insect, the wingless females of which have the power of making from the Nopal the well-known scarlet dye. $f, 500,000$ worth of cochineal has been annually exported from Mexico alone, but most of the British import comes from Teneriffe.

Echinocactus resembles a Melon, bristling all over with thorns, which are used in Mexico as toothpicks (E. visnaga; visnaga $=$ toothpick). E. cylindraceus has long curved spines.

Cereus develops some of the most splendid, although in general the most short-lived of flowers. C. grandiflorus, the Night-blowing Cereus, when in the Garden, put forth, now and then in the close of evening, one or more blooms of great beauty, whose fragrance was sufficient to fill the whole house with a delicate perfume of vanilla, but by the morning it was closed and faded. Unfortunately the house is only open to the public for two hours in the afternoon.

Of Pilocereus senilis, the Old Man Cactus, with leaves represented by white wool like an old man's hair, the Garden possessed a venerable specimen said to have been several hundred years old, but it died shortly after No. I2 Greenhouse had been heightened for him. His shrivelled skin in the museum is $15 \mathrm{ft}$. long. There are large plants in Mexico which, from the slowness of their growth, may be as much as a thousand years old. C. giganteus attains to a height of $50 \mathrm{ft}$. 
The species of Phyllocactus are usually grown grafted upon the stems of other plants, such as Opuntia. The practice is not new. Epiphyllum truncatum was grafted on Pereskia aculeata stock at Oxford, circ. I834-7.

Belonging to quite a different family are the Euphorbias or Spurge-cactuses, the leafless forms of which resemble the True Cactus, but are readily distinguishable by the milky juice which runs freely from the smallest wound. This juice is so exceedingly poisonous that it is used in the preparation of poisoned arrows by certain S. African tribes.

'The fine large Euphorbia arborea in the middle of the house is now perhaps the oldest green-house plant in the Garden.

The following are the most noteworthy of the Cacti which have been added to the collection or have flowered within recent years :

Cactus peacockii

Cereus baumanni

$$
\begin{array}{ll}
, & \text { bridgesii } \\
, & \text { formosus } \\
, & \text { jamacaru } \\
, & \text { labouretii } \\
, & \text { martianus } \\
, & \text { nycticalus } \\
, & \text { quisco } \\
, & \text { schelhasii } \\
, & \text { smithii } \\
, & \text { tephracanthus } \\
, & \text { tweediei }
\end{array}
$$

Echinocactus capricornis

$\begin{array}{ll}, \quad & \begin{array}{l}\text { corynodes } \\ \text { cylindraceus, var. } \\ \text { longispinis }\end{array} \\ & \text { grusonii } \\ , \quad & \text { horridus (?) } \\ , \quad \text { lecontei } \\ , \quad \text { myriostigma }\end{array}$

Echinocactus ottonis, var. tortuosus pfeifferi williamsii

Epiphyllum gartneri

Euphorbia Caput-medusae

,$\quad$ colletioides
,$\quad$ meloformis, var. corderoyii

Mamillaria castaneoides, var. cristata crassispina crinita gracilis, var. pulchella haageana heyderi kleinii lactescens longimamma nicholsonii 
Mamillaria sanguinea

$\begin{array}{ll}" & \quad \text { schelhasii } \\ " & \text { sulco-lanata } \\ " & \text { wildiana }\end{array}$

Melocactus communis

Nolina recurvata

Opuntia cylindrica, var. cristata

, dillenii

" leucotricha (?)

, monacantha

" polyantha

, Salmiana

Opuntia spirocentra

, vestita

Pelecyphora aselliformis

Phyllocactus crenatus

latifrons

Rhipsalis clavata

$\begin{array}{ll}" & \text { funalis, var. minor } \\ " & \text { myosurus } \\ " & \text { penduliflora } \\ , & \text { salicornoides, var. } \\ & \text { stricta } \\ & \text { suareziana } \\ , & \text { sulcata } \\ " & \text { zanzibarica }\end{array}$

On a shelf near the glass is the collection of Stapelias or Carrion-flowers, so called because certain species are said to announce their flowering by the exhalation of an indoloid stench so putrescent as to attract flies, which are thus tricked into laying their eggs on the plant, mistaking it for putrid meat. The innocent grubs, when hatched, soon discover the difference and die of starvation! To such depths of subterfuge does Nature descend in her efforts to secure cross-fertilisation!

Stapelia gigantea, hamata, mamillaris, planiflora, and stricta, were obtained in $189 \mathbf{r}-3$.

Of the Aloe-like plants there are a great number of species which are conveniently divisible into the genera:

Aloe, with large flowers.

Apicras, with small flowers.

Haworthia, with scarcely any stem ; flowers pendulous. Gasteria, " , , , , , " erect.

Socotrine Aloes, from $A$. perryi, is the medicine so extensively employed in quack pills; Barbadoes Aloes is derived from $A$. vera; $A$. mitraeformis is remarkable for its thick succulent leaves, pointed at the apex and disposed in pairs 
so as to bear some resemblance to a bishop's mitre; $A$. saponaria is used by the negroes for soap.*

These True Aloes are all Liliaceous plants, and must not be confounded with the American Aloes, which belong to the Narcissus Order or Amaryllidaceae.

One of the few remarkable things a visitor $\dagger$ took notice of in the Garden in $\mathrm{I} 695$ was " $\mathrm{Y}$ e Aloes plant $\mathrm{w}^{\mathrm{ch}}$ is like a great flag in shape, leaves and Coullour, and grows in the fform of an open Hartichoake and towards the bottom of each Leafe its very broad and thick, In $w^{\text {ch }}$ there are hollows or receptacles for $\mathrm{y}^{\mathrm{e}}$ Aloes."

In 1846 an American Aloe (Agave, Furcraea cubensis), grown in the stove, attracted much interest by suddenly pushing forth a splendid panicle of flowers, which rose in a week to the height of $24 \mathrm{ft}$. The earliest blossoms expanded on October I, and by October 7 the flowering stem had produced 28 principal branches, on which, and on the subordinate ones, were no less than 1,388 flowers and pseudobuibs. A multitude of the latter were interspersed amongst the blossoms as a provision for the future propagation of the plant, which died exhausted by the great effort of producing a vast assemblage of flowers in so rapid a manner. A drawing by J. H. Russell hangs in the Museum. The last specimen flowered in $\mathrm{r} 893$.

In more recent years the flowering of large Aloes has not been a phenomenon of such rare occurrence-in fact, by attention to their cultivation, healthy plants can be induced

* The collection also includes:

Aloe albo-cincta

, aristata

", greenii

" percrassa

", somaliensis

" supralaevis

Gasteria croucheri
Gasteria vroomii

Haworthia reinwardtii

Kalanchoë flammea

$\begin{array}{ll}" & \text { glaucescens } \\ " & \text { kirkii } \\ " & \text { somaliensis } \\ " & \text { thyrsifolia }\end{array}$

$\dagger$ Celia Fiennes. 
to flower at a much earlier age than was formerly believed to be the case.

The American Aloes and Furcraeas are an important source of fibre for making cordage. A strip of the flower-spike makes an excellent razor strop.

We have in the collection:

$$
\begin{array}{cl}
\text { Agave americana } & \text { dasylirioides } \\
, " & \text { glaucescens } \\
, & \text { lophantha } \\
, & \text { Victoriae Reginae }
\end{array}
$$

Agave xylacantha ," yuccaefolia Furcraea elegans " lindenii " longaeva

Agave baxteri was sent to Kew by Professor Lawson, along with the other succulents, of which a list is given in Appendix B.

Related to the Aloes are the Dagger Plants, Yucca, a hardy species of which has been noted on page 85 with the Lilies in the Herbaceous Beds. $Y$. filifera and a variegated variety of $Y$. recurva are grown. Other species have an economic value for cordage and paper-making.

But perhaps the greatest treasures of the house are the fine African Dracaenids, Dasylirion longifolium and latifolium, and especially $D$. glaucophyllum, which came to the Garden as a seedling from the collection of $\mathrm{Mr}$. Wilson Saunders of Reigate, Surrey, about 1852 , under the name of Bonapartea robusta. A glaucophyllum flowered in I9II.

At the end of the house are the succulent species of Cacalia, Senecio, Echeveria, and several remarkable Crassulas, as $C$. arborescens, lycopodioides, rubicunda, portulacoides, and perfossa, the leaves of which latter are attached so slightly to the stem that they may be turned round at pleasure. In 1864, I30 species of Mesembryanthemum were grown, many of them Haworth's types and some the "legitimate descendants" of Sherard's plants. For in his description of an Oxford specimen of $M$. linguiforme L., var. M. latum, Haworth wrote: "This ancient species was obligingly communicated to the author in 1819 , from the celebrated garden 
of Oxford, by the Regius Professor of Botany, Dr. Williams; together with cuttings of all the other Mesembryanthema then living in that Collection: which I conceive there is every presumptive reason to suppose are the legitimate descendants of the far-famed Sherardian stock at Eltham ; and which shine so conspicuously in the works of Dillenius. Of all the Mesembryanthema that celebrated botanist has so interestingly figured in his matchless Hortus, M. serratum alone is lostall the others are now alive before the writer" ("Rev. Plantarum Succulentarum," p. 98, I82 I).

Many of these plants are of exceeding slow growth, taking a long time to arrive at maturity. They thrive in the sandy deserts of Arabia, where they are enabled to retain for a long time the water they imbibe during the short rainy season.

The Cycad, Encephalartos altensteinii, is grown in this house. Concerning Cycads, see p. II5.

\section{No. i i. The Propagating-House}

(Not open to the Public)

A Propagating-Pit was built in $185^{2}$ (?) and was reroofed in I 866 , but the present house is a much more recent structure.

The contents of this house of necessity undergo frequent changes with the season and the needs of the collections in the other houses. Among the more permanent flora are some examples of exceedingly interesting species of flesh-eating plants, which Darwin made the subject of a special monograph, "The Insectivorous Plants."

The humble Drosera or Sundew has leaves, says the old herbalist Parkinson, that are continually moist in the hottest day, "yea the hotter the Sunne shineth on them, the moister they are, with a certain sliminesse that will rise into threads." When a small fly settles on a leaf it is immediately glued by the clammy drops, and the adjoining hairs bend round the 
insect on every side and hold it fast. Thus does the Sundew obtain its nitrogenous food.

The leaves of Venus' Fly-Trap, Dionaea muscipula of $\mathrm{N}$. America, are even more wonderful. They are modified to form a spring gin, the spine-fringed jaws of which snap together over any luckless fly or piece of meat which may touch the two or three sensory hairs situated in the centre of each of the jaws.

The Sarracenias of $\mathrm{N}$. America have tubular leaves in which water lodges, and in which many insects meet with a watery grave.

Sarracenia vittata, maculata and williamsii were added to the collection in 1894 .

In IgrI the house contained young plants of the Asclepiadeae. Ceropegia barklyi, debilis, gardnerii, perforata, radicans, sandersoni, stapeliaeformis, and many seedlings of the Sensitive Plant, Mimosa pudica, are also raised to replace worn and torn specimens in the other houses, which may have been roughly fingered by visitors.

\section{The Old No. I 2 Green-house}

Erected by Professor Daubeny in 1866 for plants requiring protection in winter, this house is now one of the oldest in the Garden. Part of the roof was raised in 1879 to accommodate the "head" of the Old Man Cactus, a centenarian which unfortunately died shortly afterwards, in transplanting to the new house.

On either side of the entrance is a specimen of the Hottentot's Bread or Elephant's Foot, Testudinaria elephantipes, from S. Africa, a very curious member of the family of the Yams. The rounded rootstock which rises above the ground, is covered with a hard corky bark cracked in various directions, so as to bear a fancied resemblance to its ungainly namesake. It has been known to grow over $7 \mathrm{ft}$. in height and to weigh 
nearly $700 \mathrm{lb}$. From the middle of the top, shoots out a slender leaf-bearing stem not unlike that of our common Black Bryony, which belongs to the same family.

Another noteworthy plant is the fine Rhododendron ciliicalyx, discovered by the Abbé Delavay in Yunnan, and figured in the Rerne horticnle for 1899 , the year after a plant flowered at Oxford, having been raised from seed by the custodian of the Garden, Mr. Baker, about 1890 .

In two Wardian cases is a collection of Filmy Ferns, a recent acquisition, some of which have been noted in the list of Stove Ferns.

In I9 I the collection included the following species:

Anemonopsis macrophylla

Araucaria ruleii

Bulbine praemorsa

Campanula vidalii

Cassia sp.

Catha edulis

Ceratonia siliqua

Cestrum luridum

Citrus decurrens

Crotalaria pumila

Cuscuta chilensis

reflexa

Darlingtonia californica

Datura knightii

Erythrina crista galli

Eucalyptus pulverulenta

Ferraria ferrariola

Heterotoma lobelioides

Houttuynia cordata

Marsilea aegyptiaca

Musa ensete

Musschia aurea
Nandina domestica

Nerine borodeni

Nerium oleander

Nymphaea pygmaea

Olea europaea

Pavonia spinifera

Podocarpus sp.

Pontederia cordata

Rehmannia angulata

Rhododendron ciliicalyx ' 98 decorum

Sagittaria lancifolia, var. major Spondias solandei

Streptocarpus daviesii

$\begin{array}{ll}, & \text { dunnii } \\ ", & \text { haygarthii } \\ ", & \text { saundersii } \\ ", & \text { wendlandii }\end{array}$

Tecoma

Vestia lycioides

Villarsia

Yucca aloifolia 


\section{WEEDS AND WILD PLANTS}

Better to me the meanest weed

That blows upon its mountain, The vilest herb that runs to seed

Beside its native fountain.-TENNySON.

\section{Flowering Plants}

BY G. C. DRUCE

Among the alien species recorded in Druce's "Flora of Oxfordshire" which owe their origin to the Botanic Garden and are now naturalised on the handsome walls erected by Danby are Hieracium amplexicaule L., Chondrilla juncea L., Senecio squalidus L., the Oxford Ragwort, Linaria purpurea Miller, and L. Cymbalaria Miller, which was there in the time of Dillenius, and was the plant which Linnaeus expounded in so able a manner as to commend him to Dillenius.

The walls of Rose Lane formerly had Valerianella carinata, which Baxter found in May, I84 I, and figured from this place in his "Phaenogamous Botany," and Phleum paniculatum Huds., recorded by Sibthorp in his "Flora" of I 794 ; but these are no longer there. The plant of Rumex scutatus which grows in the vicinity may owe its origin also to the Garden.

The unspotted Lamium maculatum L., on one of the islands near the Cherwell, originally found by Baxter in I8I5, is probably another of the stragglers, as was the solitary plant of Althaea officinalis in the Long Meadow in 1815 ; but on 
the whole the Botanic Garden cannot be said to have much influenced the surrounding flora.

Viscum album L., the Mistletoe which is so frequent on so many trees in the Garden (p. 79), has been conveyed to some tall Swiss Black Poplars in Christ Church Meadow, and possibly to the Hawthorn in the Parks.

In the Garden beds year by year, for the last eighty years, appear self-sown Sisymbrium Irio L., Erodium maritimum, and Ajuga Chamaepitys, and the same form of Bursa pastoris which Baxter gathered there in 1820 still abounds.

On rubbish carted away from the Garden and deposited on waste ground on the Iffley Road, and in the Marston Brickyards many alien species grew in I910; these included :

Atriplex hortensis, L.

Atropa belladonna, L.

Barbarea verna, Asch.

Blumenbachia insignis, Schrader

Datura Tatula, L.

Doronicum austriacum, Jacq.

Glaucium corniculatum, Curtis , luteum, Scop.

Lamium garganicum, L.
Leonurus Cardiaca, L.

Lychnis Coronaria, Desr.

Malva verticillata, $L$.

Mathiola bicornis, $\mathrm{Br}$.

Potentilla recta, L.

Reseda alba, L.

Sisymbrium Irio, L.

$$
\begin{gathered}
, \quad \text { strictissimum, L. } \\
\text { G. C. D. }
\end{gathered}
$$

In addition to a few of those mentioned in Mr. Druce's list, Dr. Daubeny noted Cochlearia officinalis and Euphorbia portlandica on the rockwork near the South Tank, Lepidium iberis in front of the Entrance Gateway, Erigeron acris on the South Wall, and Sedum dasyphyllum on the walls and coping of the Conservatory.

A short list given in the Gardeners' Chronicle for 1872, p. 733, mentions the "ill-named Senecio squalidus, the curious Impatiens parvifora, the quaint Claytonia perfoliata, the ill-smelling Hieracium amplexicaule, a neat species of Cxalis [? corniculata], the gay Centranthus ruber, and the peculiar Ground Pine, Ajuga chamaepitys."

And possibly of greater interest still, the Yellow Tulip, Tulipa sylvestris, of Christ Church Meadows may have been a Garden escape. It was found in 1869 by my friend Mr. Hatchett Jackson, growing near the ditch which used to run along the south side of the Broad Walk, and his father had specimens from the same locality in his herbarium at a much earlier date (R. T. G.). 


\section{Algae}

Spawn, weeds, and filth, a leprous scum, Made the running rivulet thick and dumb.-ShELLey.

The earliest mention of an Alga living in the Garden is that by Uffenbach in I 7 Io (p. I 2), but we cannot be certain what it was. It may have been the Goat Ball Conferva, C. aegagropila L., balls of which, 2 in. in diameter, Baxter used to pull out of a shaded pan of water much to the astonishment of his visitors. It throve as it would have done in its native meres.

Gonium pectorale occurred in abundance one year in the Lily 'Tank during Professor Lawson's time (E. R. L. ex lit.), and in 1894 , the first year of the new tank, the water was green with it.

Algal growths in the tanks are very naturally regarded as a nuisance, and the latter are subject to periodical cleanings, which do not encourage their growth on a large scale.

The local Algal Flora has never been worked at systematically, or the list would have been extended "to infinity."

\section{Chlorophyceae}

Chara

Mougeotia

Closterium

Spirogyra

Pediastrum

Cladophora

Gonium (occasional)

Pandorina

Vaucheria

Scenedesmus
Chlorophyceae (cont.)

\section{Diatoms}

Pinnularia

Navicula

Melosira

etc.

Cyanophyceae

Oscillatoria

Abundant in Green-houses Anabaena

Nostoc

Gloeocapsa

\section{FUNGI}

In 1889 the author found the Peach-coloured Bacterium, B. rubescens, described by Ray Lankester in the "Quarterly 
Journal of Microscopical Science," I873, growing in plenty in the old lead cistern which stands just within the Danby Gate. A few years after, the tank was repaired and thoroughly scoured and the $B$. rubescens disappeared.

A good garden is known by the rarity of its Fungoid inhabitants: none are of any use, and many cause the most injurious diseases. Diseased plants are promptly thrown away, and so, although the list might be extended possibly to $100-200$ forms, the number recognised is very low :

BASIDIOMYCETES

Agaricus sp.

Stereum

On wood

Aecidiomycetes

Ustilagineae

Ustilago vaillantii

On Muscari sp.

\section{Uredineae}

Gymnosporangium

On Juniper (formerly)

Ascomycetes

Sphaeotheca, Hop Mildew Peziza $\}$ On decaying logs

Bulgaria $\}$ in the yard
Ascomycetes (cont.)

Nectria) On decaying logs

Xylaria $\}$ in the yard

Phycomycetes

Saprolegnia

On gold-fish

Pythium

On seedlings

Cystopus

On weeds

Phytophthora

On weeds

MyXomyCeTES

Badhamia

Stemonitis

Didymium

\section{FAUNISTIC NOTES}

It may seem strange, but it is true, that to many minds the greatest attractions in the Garden are not the plants, but the animals. Dr. Daubeny's monkeys have been already mentioned. Many visitors who cared nothing for plants came to see them. It is not recorded whether or no a purchaser was found for them after the Doctor's death, but Mr. William Hine informs me that he was deputed to fetch them away, alive or dead, to 
the Museum, where they underwent post-mortem examination on Professor Rolleston's dissecting-tables.

To-day the chief object of interest to many visitors to the Garden is the tank with the Gold-fish which will eat crumbs, in the Water-lily House. A few years ago, the same house was regarded with awe by the younger generation, partly because it was always locked up, and partly because it had the unearned reputation of being the place where the "Magdalen Giant" was grown.

For those who are interested in historical records, we may note that the first recorded fish-tank in the vicinity was the open-air pond belonging to Magdalen College at no great distance from the Garden.

In 155 I the College leased an ichthyotrophion sive vivarium piscarium, situated between the cubiculum promorum on the west and the College meadow on the east (Macray's Register).

In 1856 two prizes of $£_{25}$ and $£_{20}$ were offered by the Lee's Reader in Anatomy for the two best monographs "On the Fauna of Christ Church Meadow and the adjoining Waters." The larger prize was for the Invertebrate, the smaller for the Vertebrate Fauna, and the essays were to be sent to the Dean of Christ Church, who was assisted by a strong body of judges. But according to Cox * no essay was sent in.

In $185^{8}$ Dr. Acland and Sir Walter Trevelyan offered another prize for the best essay "On Rearing Fish in the Cherwell and Isis."

\section{BIRDS}

The earliest note I have come across relating to a bird in the Garden is about a Thrush which built its nest in the middle

* Cox wrote, that since the recent masonry and palisades round "the Meadow," it would be idle to look for specimens of Fauna or Flora there :

Stone and iron will soon environ All Oxford Walks, or near it ;

But be it known to iron and stone,

That men of taste can't bear it, 
of a large bunch of Mistletoe in I864. Nearer our own time, Mr. Warde Fowler* has drawn attention to the presence of the Thrush tribe throughout the autumn: "In the Gardens the thrushes and blackbirds have become so tame from constant quiet and protection, that, like the donkeys at Athens of which Plato tells us, they will hardly deign to move out of your way. . . . Missel-thrushes are also to be seen here; and all these birds go out of a morning to breakfast on the thickly-berried thorn-bushes at the Cherwell end of the Broad Walk, where they meet with their relations the Redwings, and now and then with a Fieldfare."

The Lesser Spotted Woodpecker, Dendrocopus minor, nested in a hole in an old tree not long ago (H. A. Evans, 1905). The great Poplar which fell a year ago across the Cherwell beyond the southern boundary was a favourite tree with the Owls, which also often sit in the south-east corner of the Garden.

The Goldcrest, Regulus cristatus, has frequently built in the Garden, and even the Firecrest, $R$. ignicapillus, has been recorded there on February I3, 1882, by A. R. Battye.

And last, but not least, I have been informed that Mr. G. Tickner, who knows Oxford birds well, states that he saw a Black Redstart sitting in a tree near the water, and, after some search, found its nest in one of the creepers against the South Wall, whence he took an egg for his collection (June I6-20, 1902).

"In the summer of 1886 the Reed Warbler, Acrocephalus streperus, was quite abundant in and round Oxford. If I am not mistaken, a nest was built in the reeds of the fountain at the south end of the Botanic Garden, a perfectly secure spot. I heard the song there as late as the end of July" (IV. W. F.).

And the same authority informs me in a letter that "in * "A Year with the Birds." 
May I 888 and I 889 a Reed Warbler sang in the privet hedge just outside the turnstile by the School, and in a bush just inside the privets, in spite of the school-children; the song was so unusually fine for a Reed Warbler that I began to think it must be a Marsh Warbler, a bird I did not then know. Nests of the Reed Warbler used to be built in lilacs, privets, etc., in the city, but now the numbers have clearly diminished, and one has to go further to find them." Mr. Warde Fowler shortly afterwards visited the Alps and proved that the wonderful singer of the Garden was after all only a highly-gifted Reed Warbler.

"Flycatchers used to sit on the labels occasionally and catch the bees, as one might prove by the little parcels of wings and legs which they dropped on the ground. Blackcaps and Willow-wrens were, and probably still are, the characteristic summer singers. One year at lesst I remember hearing the Lesser Whitethroat singing in bushes just by the gate into the High Street; it was for some years very abundant all about the city. But of late I have not heard so many" (Letter of October 5, I9I I).

But on the whole, Mr. Warde Fowler-and no one has watched the birds more closely-does not consider the Garden so good for birds as, for example, Parson's Pleasure, which for some reason has attracted travellers like the Pied Flycatcher and the Wood-wren.

\section{FROGS}

"A curious fact I remember is that the gardeners used to collect frogs for us in early summer, and that many (quite a large proportion) had mutilated fore-limbs and sometimes ditto hind-limbs. I never heard what this could be due to-perhaps frost-bite during hybernation, or perhaps rats! I should rather like to know if it has been observed sinceand if known elsewhere as common " (E. R. L. ex lit.): 


\section{BeEtLeS}

Recorded from the Botanic Garden, unless another locality is given :

Calathus melanocephalus, L. R. G. Heledona agaricola, Hbst.

Anchomenus puellus, Dej. Ch. Ch. Holme

Ocypus fuscatus, Gr. Ch. Ch. Holne

Dacne humeralis, F. Ch. Ch.

Mycetophagus piceus, F. Taken in 1820 by $F . W$. Hope

Clytus mysticus, L. F. W. H.

Bruchus seminarius, L. Baxter

Crioceris 12-punctata, L. F.W.H.

Phaedon tumidulus, Germ. R. G., 1890

Sermyla halensis, L. $F . W . H$., 1820

In fungus on a dead Birch. Ch. Ch.

Pyrochroa serraticornis, Scop. R.G., 1890

Apoderus coryli, L. F. W. $H$.

Otiorrhynchus sulcatus, F. Very common. F. W. $H$.

Orchestes alni, L. Magdalen Grove. R. G.

Ceuthorrhynchus contractus, Marsh. R. G., 1890

Ceuthorrhynchus pollinaris, Forst. Baxter, 1820

Calandra oryzae, L. Baxter

Cossonus ferrugineus, Clairv.

In a decaying elm, Sept. 1893. R. $G$.

FLIES

BY A. H. HAMM

The following are a few of the more interesting Flies found in the Garden :

DiPTERA

Syrphus ribesii, $\mathrm{L}$.

" bifasciatus, Fab.

", corollae, Fab.

" balteatus, Beg.

Sphaerophoria scripta, L.

Ascia podagrica, Fab.
DIFTERA (cont.)

Eristalis tenax, L.

, arbustorum, L.

, pertinax, Scop.

Helophilus pendulus, L.

Syritta pipiens, L.

Bombilius major, L.

\section{SAW-FLIES}

Both Nematus ribesii, the Currant Saw-fly and N. gallicola, which occasions the Bean Galls or red swellings on the leaves of the Willow, have been found in the Garden. 


\section{Ants, BeEs, And Wasps}

BY W. E. HILEY AND A. H. HAMM

The plumèd insects swift and free

Like golden boats on a sunny sea

Laden with light and odour, which pass

Over the gleam of the living grass.-SHELLEv.

\section{Hymenoptera ACuleata. IIETERogyna}

Lasius niger, L. This common garden ant is abundant in the grounds and houses.

Myrmica rubra, L. Common in the grounds.

Plagiolepis flavidula, Rog. This exceedingly small exotic ant is sometimes abundant in the Palm and Orchid Houses. It is a native of S. America, Cuba, etc., and is also found in the hot-houses at Kew and Cambridge, no doubt having been introduced with plants from abroad.

\section{FOSSORES}

Trypoxylon figulus, L.

Stigmus solskyi, Moran.

Psen pallipes, Panz.

Crabro tibialis, Fab.

" cephalotes, Panz.

\section{DIPLOPTERA}

Vespa vulgaris, L.

" germanica, L.

, rufa, L.
Diploptera (cont.)

Vespa sylvestris, Scop.

," Austriaca, Panz. This

is a most interesting wasp, as it makes no nest, but is probably inquiline upon $\mathrm{V}$. rufa.

Odynerus parietum, L.

" gracilis, L.

, callosus, Thoms.

BeEs are of especial interest in a Botanic Garden, since the careful watching of their habits enables the observer to see some of the complex floral mechanisms at work. With some exotic plants, such as those pollinated by humming birds, it is impossible in England to see the flowers pollinated as they are intended to be; but for most garden types the English insects are sufficient, overcoming by their ingenuity the difficulties of mechanisms formerly unknown to them. The following is a list of the bees recorded for the Botanic Garden :

\section{ANTHOPHILA}

Prosopis signata, Panz.

" communis, Nyl.

". brevicornis, Nyl.
AnTHOPHila (cont.)

Halictus leucozonius, Schenck.

" cylindricus, Fab.

$" \quad$ nitidiusculus, Kirb. 
ANTHOPHILA (cont.)

Halictus tumulorum, L. "Smeathmanellus, Kirb.

Andrena albicans, Kirb. "rosae, Panz.

" fulva, Schr. This bee makes nests on the edges of paths and beds, throwing up small mounds, which are very numerous all over the Garden in May.

Andrena nigroaenea, Kirb. wilkella, Kirb.

Nomada succincta, Panz.

$" \quad$ alternata, Kirb.

", ruficornis, L.

Chelostoma florisomne, $\mathrm{L}$. " campanularum, Kirb.

Megachile ligniseca, Kirb.

Osmia rufa, L. centuncularis, $\mathrm{L}$.

"fulviventris, Panz.

Anthidium manicatum, L.

Melecta armata, Panz.

Anthophora pilipes, Fab. This
ANTHOPHILA (cont.)

bee appears in the early spring, and is the only bee out at this time which has a proboscis as long as $20 \mathrm{~mm}$. It therefore monopolises all the flowers with corolla tubes of more than $15 \mathrm{~mm}$. It is later replaced by Bombus hortorum, which has a proboscis of about the same length, but does not appear in large numbers till June.

Psithyrus rupestris, Fab.

vestalis, Foure.

These two bees are inquiline on various species of Bombus which they resemble.

Bombus venustus, Smith.

" agrorum, Fab.

" hortorum, L. See note on Anthophora pilipes.

Bombus terrestris, L.

$" \quad$ sylvarum, L.

" Derhamellus, Kirb.

, lapidarium, L.

Apis mellifica, L.*

Hymenoptera Tubulifera. Chrysididale

Chrysis ignita, L.

", cyanea. These two Ruby-tails are parasitic on the Aculeata.

\section{Mites}

Eriophyes (Phytoptus) rudis was responsible for the IVitches' Brooms $\dagger$ which used to hang like rooks' nests from the old Birch in the Garden prior to its removal, and there are several examples in Christ Church Meadow. A fine specimen of the result of this mite taking up its domicile in the young buds of a Hornbeam may be seen near the further end of Addison's Walk. It was the subject of an amusing practical joke in VIIIs' week, I903. See plate, p. 2 I 4.

* It may be of interest to record that in May, I838, the Oxford Apiarian Society made a rule "To keep a garden for experiments on bees." The leading spirit was W. C. Cotton of $\mathrm{Ch}$. Ch.

$\dagger$ Witches' Brooms are also caused by a fungus. 


\section{Crustacea}

Trichoniscus (Philougria) roseus, No. I 2 Green-house, I896.

\section{Molluscs}

Physa acuta and P. hypnorum are stated to have been taken in the Lily House in 1902.

A foreign species of Bulimus was discovered on the Water-lilies in the tank by Mr. G. D. Carpenter, and from the same source Sir Ray Lankester used to obtain Paludina for his embryological researches, including among others the demonstration of the coincidence of blastopore and anus.

Sir Ray Lankester also informs me that he once procured thirty great orange-coloured Slugs, Arion rufus from Germany, and tried to keep them in a large cucumber-frame, but they all escaped into the Garden, unfortunately without establishing themselves there !

The Roman Snail, Helix pomatia, was to be found in the Garden some years ago (A. H. C.). It is so no longer, for the gardeners, who in virtue of their manhood "have dominion over every living thing that moveth upon the earth," do not pause to consider Cowper's teaching :

An inadvertent step may crush the snail That crawls at evening in the public path;

Yet he that has humanity, forewarned, Will tread aside, and let the reptile live.

\section{WORMS}

\section{(For a list of the Earthworms, see p. 260.)}

That most interesting terrestrial Flat-worm (Planarian) Bipalium kezenense, first discovered crawling on damp surfaces in Kew Gardens, turned up in the Banbury Road, in J. T. Filsell's Orchid House, in I898, but I can find no certain record of its having appeared in the Botanic Garden. 


\section{CLIMATE AND SOIL}

The situation of Oxford is low and watery, the neighbouring meadows being overflowed, close to the garden, after the autumnal rain, so that the dews and heavy morning fogs will scarcely allow the plants of hot climates to attain perfection.-DILLENIUS in 1742 or 1743 .

Horto [nostro] insigne damnum attulit gelu superioris anni insolitum quod omnes Galliae Narbonensis, Italiae, Hispaniae et Africae citerioris plantas, quae nobiscum aerem liberum ferunt et in solo plantatae erant, pessumdedit.-Dillenius to Haller, Dec. I I, I740.

Knowing how closely climatic conditions are connected with success, or the reverse, in horticulture, Dr. Daubeny commenced a Meteorological Record of observations made in the Garden and at his Laboratory. This record is still kept at the Daubeny Laboratory, and some of the means have been published in the "Report of the British Association" for $\mathbf{1} 89 \mathrm{I}$ and in the "History of the Daubeny Laboratory" in I 904-so that it is unnecessary to go further into the matter here.

The effect of weather on the growth of garden plants has not yet been studied with any great accuracy of detail, although the more general effects are perfectly well known to all successful horticulturists.

And the same is true of the soils. No one knows better than Mr. Baker what our Oxford soil will and will not grow, or what ingredients it is necessary to add to it to make it grow a particular species of plant; but it is very probable that no chemical or bacteriological analyses have been made of it since Dr. Daubeny attempted the former in the middle of the last century. 


\section{WALL PLANTS, CLIMBERS, E'TC. NORTH WALL}

Clematis, Ville de Lyon

, Nelly Moser

, Jackmanni superba

DOOR

, Ville de Paris

" $\quad$ Princess of Wales

, Snow-white Jackmanni

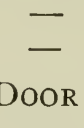

\section{DOOR}

$\begin{array}{ll}\text {," } & \text { Marcel Moser } \\ , & \text { Lucie Lemoine } \\ \text { Clematis } & \text { Countess of Lovelace }\end{array}$

Clematis lanuginosa

\section{DOOR}

Clematis, M. Edouard André

Tropaeolum tuberosum

Clematis pitcheri

MAGNOLIA GRANDIFLORA

Magnolia yulan, China Ficus

W. END

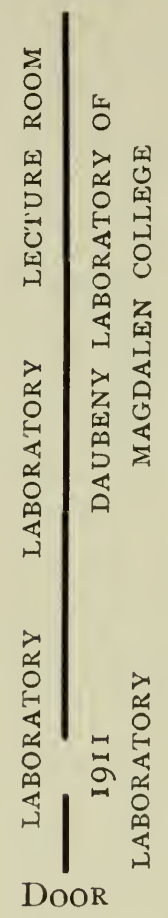

Vitis

\section{Lead Tank (I780) \\ DANBY GATEWAY}

Paliurus aculeatus, L.,

S. Europe

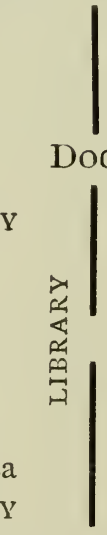

No. 3 Conservatory

Ampelopsis quinquefolia

Clematis

Clematis

? Passiflora

Ampelopsis quinquefolia

Phlomis fruticosa

No. 4 Conservatory

\section{DOOR}

E. END 


\section{EAST WALL}

N. END

Kerria japonica

Rose

Rose, Rêve d'Or

Ivy

Ivy

Lonicera japonica, var. aurea reticulata

Ivy

Ivy

Berberis stenophylla

Ivy

Vitis vinifera, var. apiifolia

Rose

Smilax sarsaparilla, N. Amer.

Ivy

Vitis vinifera, var. foliis incanis

Ivy

Kerria japonica

Aristolochia sipho

Rose

Kerria japonica

Rubus

Menispermum canadense

Ivy

IVISTARIA

Ivy

Kerria japonica fl. pl.

Thirteen Ivies
Crataegus pyracantha, var. lelandi

Ceanothus azureus, Mexico, var. Gloire de Versailles

Ceanothus veitcheanus, California

Manettia bicolor

Jasminum sambac

Solanum wendlandii

Grevillea robusta

Strobilanthus sabianus

Arundinaria donax variegata

Smilax OFFICINALIS

$\rightarrow$ Stygmaphyllum ciliatum

in Combretum grandiflorum

If Ipomaea atropurpureum

Phyllanthus retusa variegata

Pithecoctenium aubletii

Aristolochia elegans

Combretum purpureum

Aristolochia ornithocephala

Bougainvillea cypheri

\section{EAST GATE}

Reinwardia trigyna

Ipomaea sellowii

Reinwardia trigyna

Justicia carnea

Semele androgyna

Passiflora princeps

Mackaya bella

Plumbago capensis

Jasminum sambac

Lonicera sempervirens, var. minor

$\rightarrow$ Jasminum primulinum

(2) Abutilon thompsonii fl. pl.

Streptosolen jamesonii

Bignonia cherere

Jacobinia mohintli

Hoya carnosa

Cestrum newellii

Justicia carnea

Bignonia venusta

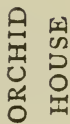

Solanum jasminioides 


\section{SOUTH WALL}

Ivy

North Aspect

E. END

Ivy

Rose

South Aspect

Ivy

Rose

Rubus biflorus, Himalayas

Rubus ichangensis

Bupleurum fruticosum

Rubus deliciosus, Torr. N.W. America

(Weigelia) Groenwegei

Azara microphylla, Hook, Chili

Ivy

Choisya ternata, Mexico

Rosa acicularis, China

Celastrus articulatus, Thunb., Japan

Cotoneaster horizontalis, China

Rubus lasiostylis

Vitis armata, var. Veitchii

Jasminum nudiflorum, China

Actinidia arguta

Rubus parkeri

Philadelphus triflorus

Rubus flosculosus

Euonymus Koopmanni

Ivy

Hedera spectabilis aurea

Rose

GATE

Rosa multiflora

Punica granatum, S. Europe

Magnolia grandiflora, N. America

Anagyris foetida, $L$.

Pyrus japonica, var. alba

Rose

Akebia quinata

Vitis coignetiae, Japan

3 Rose, Richardson

Vitis thompsonii

I Clematis montana, var. rubens

Jasminum primulinum

Rose, Yellow Banksian

Pyrus japonica

Genista aethnensis, Sicily

Tamarix gallica

PYRUS JAPONICA

Wistaria multijuga

Rose

Parrottia persica, Persia

Ercilla volubilis, Peru

Lonicera

\section{SOUTH GATE}

Ivy

Lonicera periclymenum, var. lutea

Crataegus mexicana, Moc. et Sesse, Mexico, 1824

Rose

Lonicera fragrantissima, Lindl., China

Rose

Rose

Berberis vulgaris, $\mathrm{L}$.

Ivy

Buttress

Berberis stenophylla

Lonicera discolor, India

Rose

Rubus henryi

Schizophragma hydrangeoides, Japan

Forsythia suspensa, China

Viburnum cotinifolium, Himalayas, 1832

Cotoneaster microphylla, Himalayas

Ivy Buttress

Diervilla rosea, var. variegata, China

Kerria japonica, var. variegata

Rose

Kerria japonica, var. variegata

Lonicera etrusca Santi, Mediterranean

Rose

Kerria japonica

Lonicera brachypoda, Japan

Rose

Ivy

Rubus

Euonymus japonicus, var. radicans

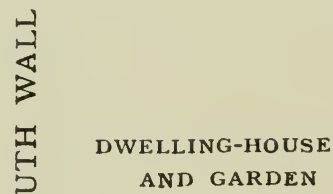
variegata 


\section{WEST WALL}

N. END

Eriobotrya Japonica, Lindl.

Rhamnus dahurica, N. India

Caryopteris mastacanthus, China

Syringa persica, var. alba

Laurus nobilis, L.

Ficus carica

Ephedra distachya, L.

Colletia spinosa, S. America

Ficus carica, var. Brown Ischia

Rose

Rose

Rose

Periploca graeca, S. Europe.

Ceanothus veitchianus

Rose

Lonicera japonica, var. aurea

Euonymus japonicus

Spiraea lindleyana

Vitis vinifera, var. corinthiaca

\section{WISTARIA SINENSIS}

The twisted rope-like branches of this large Wistaria would, if fully extended, measure $84 \mathrm{ft}$. south and $75 \mathrm{ft}$. north of the root, or $159 \mathrm{ft}$. along the wall in all.

\section{WEST GATE}

Vitis riparia

Colutea cruenta, Dry. Caucasian Region

Lycium Europaeum

Gooseberry

Rose

Gooseberry

Rose

Actinidia arguta

Clematis crispa

Lycium barbarum, E. Asia

Amorpha fruticosa, N. America

Rose, Ch. Cluster

Gooseberry

Rose

Ficus

Actinidia polygama, Japan

Rosa stylosa

Caragana arborescens

Discaria serratifolia

GaRrya elliptica, Male, N.W.

Ivy

$$
\text { America }
$$

Ivy

Jasminum officinale 


\section{THE HERBARIUM}

Old books, old flowers, old feeling, foliage pressed By time, who lays the stony weight of years.-Symonds.

A report upon the Herbarium* has been published so recently by the Delegates of the University Press that we need not reprint the lists of collections in detail, but we may express a hope that, when a new edition is printed, the name of the author may also be permitted to appear upon the title-page.

The collections of Dried Plants were no doubt at first kept with the books by the Professor in his private house, but when they became too bulky, special accommodation had to be provided elsewhere. At first the Eastern Conservatory, the present Library, was used, but in $185^{\circ}$ the old Central Western Conservatory, being no longer used for cultivation of plants, was adapted for the purpose. The collections include one of the earliest in Britain, namely, that of 300 North Italian Plants, made by Gregory of Reggio about r606, $\uparrow$ and the following:

* [G. C. Druce.] "An Account of the Herbarium of the University of Oxford," I 897. See also "The Dillenian Herbaria," Oxford, 1907, by the same author.

† This hortus siccus, one of the oldest, if not the oldest in existence, was known to Baxter, who had cleaned it in 1862 , and to Maxwell Masters (Gard. Chron., p. 808, 1889). At some time when the Herbarium was transferred from the Western Building to its present quarters (I882-4), this unique collection, with Bloxam's British Rubi, and others, were (temporarily ?) deposited above the coke in the boiler-house, and by gross 


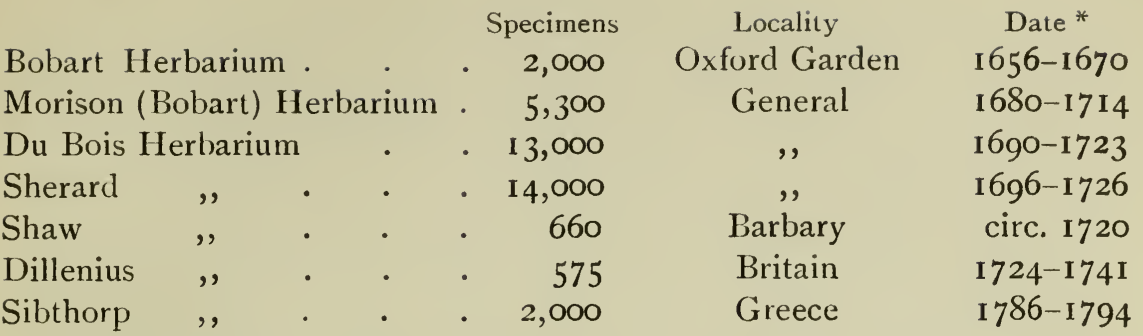

So rich were these collections in plants that Sir James Smith pronounced the Oxford Herbarium to be the best in England, until the arrival of the one which he had himself obtained from the celebrated Linnaeus.

By the acquisition of the FIELDING HERBARIUM in $1852, \uparrow$ over 80,000 specimens were added, and the collection was once more raised to a pre-eminent position among the herbaria of the world.

The Fielding Collection was at first kept on the groundfloor room of the old IVestern Conservatory, the Upper of Sherard Room being devoted to the other herbaria and to the Botanical and Agricultural Museum. This Upper Room could only be reached by a ladder so shaky that an eminent botanist, the Rev. W. Newbould, once said that, but for the carelessness left there and forgotten, except as bundles of "rubbish." The "rediscovery" was attributed by the Athenaeum, June 8, I889 (and quoted in Gard. Chron., p. 752), to the then sub-curator, Dr. Schönland, but there was no great merit in any such rediscovery, for the collection was bound in a cover made of the leaves of an Italian Service Book and clearly labelled " Herbarium Divers. Nat. Gregorii a Reggio." The real credit is due to Mr. Druce, who searched among the "rubbish," recognised the collection as the Gregory of the Bolognese Reggio (not of Reggio di Calabria), a man noted for his botanical knowledge, and who eventually undertook the remounting of the collection. See Druce, "History of Botany," Pharm. Journ., January, I890, reprinted in part in Journ. Bot., p. 276, 1890 .

* Dates revised by Mr. Druce.

$\dagger$ Donation accepted, June 15, 1852. £2,000 was voted from money received from the University Press, for maintaining and adding to the collection. £I,250 was voted for a suitable building for its reception in the Botanic Garden. 
strain it inflicted upon his nerves, Oxford would have been his place of residence (Druce, "Flora of Berkshire," p. clxxvi.). At this time William Baxter, Sen., arranged, catalogued, and kept the collections free from dust and insects with "assiduous care and unremitting attention," and was ready at all times to exhibit specimens to any one who might wish to consult them for the purpose of study. His successor was Maxwell Tylden Masters, Sub-Curator of the Herbarium, and afterwards editor of the Gardeners' Chronicle.

By I 885 all the dried collections had been moved into six rooms in the house built by Dr. Daubeny as the Official Residence for the Professor of Botany. But no account of them should omit to mention the names of Mr. H. E. Garnsey,* Fellow of Magdalen, and of Mr. Boswell, the authority on Mosses, who, as a labour of love, arranged and mounted large sections of the collection. Indeed, much would now be in poor state had it not been for their devoted services. Mr. Boswell's valuable herbarium was purchased, and is now incorporated in the general collection.

The appointment of Special Curator of the Fielding Herbarium under the direct control of the Sherardian Professor was approved by Convocation in November, I895; and the University has been fortunate to secure the services of so genial, devoted, and skilled a botanist as Mr. G. C. Druce, who for many years had placed his time and knowledge at the disposal of the officers of the Garden. Under his care the collections are gradually increasing, both by gift and by purchase, and since space is limited, it has been suggested that for the immediate future, new additions to the Herbarium should be principally made to illustrate the Flora of Europe and especially that of the Mediterranean Lands as fully as possible.

* Mr. Garnsey's work in the Herbarium is described in an obituary notice by Druce in the "Report of the Ashmolean Nat. Hist. Soc." for 1903 . 


\section{THE BOTANICAL MUSEUM}

Whilst they (as Homer's Iliad in a nut)

A world of wonders in one closet shut.-TRAdEscant Epitaph.

It would seem probable that the first museum-specimens of plants owned by the University, were exhibited with Tradescant's collection of curiosities in 1683 ; but with other things, they would have become dilapidated through neglect and have been thrown away.

Early museums generally had a botanical side. One of the most valued specimens in the Thoresby Collection at York was a pineapple-leaf; and the Sloane Collection (1753), which formed the nucleus of the British Museum, comprised 334 dried plants.

Among the Ashmolean Collections (circ. I830) were M. Louis Calamai's wax models of 24 Italian fungi and a collection of the skeletons of leaves and seed-vessels of 32 plants in a glazed frame, presented by J. S. Duncan, and catalogued in detail in the printed catalogue of 1836. There were also a bamboo cane, $60 \mathrm{ft}$. in length, in two pieces, the lower part of which had a circumference of 16 in., a branch of the cork-tree, and numerous specimens of economic interest from the Southern Hemisphere. These latter included specimens of breadfruit; a branch of the Lagetto tree, N.S.W. ; oily nuts from the Doo-doo tree; mulberry-tree slings and cloth; New Zealand flax; also paintings of John Tradescant and of G. Fairchild, ${ }^{*}$ botanists, and of tulips and of the fern called the Lamb of Tartary, the Polypodium barometz, Linn.

In the year I859, Dr. Daubeny, with the co-operation of Mr. Baxter, Sen., arranged in systematic order, in the cases of the Sherard Room (the room over the old Western Conservatory), various specimens illustrative of the structure, functions, and uses of Vegetables, for which no place could be assigned in the Herbarium.

The specimens comprised a collection of seed-vessels, seeds, stems, roots, and other organs of plants, together with products useful or ornamental, that have been obtained from their several parts. The whole was modestly described as a humble attempt to set up something in Oxford, in imitation of the interesting Museum at Kew, in connection with the Royal Botanic Garden under the superintendence of Sir William Hooker.

* Now hung in the Botanic Library ; other specimens have disappeared. 
The catalogue of the principal exhibits, published by Professor Daubeny, shows that the collection of economic products, parts of plants, and models was well arranged in systematic order in twenty-six cases lettered A to Z. After his death, convenient access to the Sherard Room, which had previously been reached by a staircase in the College Laboratory north of the wall, was cut off by order of the College, and the Botanic Museum fell into a state of neglect and was but little visited-it was "so ill-used, so ill-lighted, and so ill-adapted" (Lawson); indeed, its existence is still almost unknown in the University, partly no doubt, on account of its inaccessibility. Sections of trees and preparations of botanical specimens have, however, been added from time to time. It is a small "Naturalien-kabinet" for the more wonderful productions of the Gardens, and a store whence material for demonstration at lectures can be drawn. The specimens have been well labelled by Mr. Kempin, but data of value concerning the older specimens have been lost.

In its present condition, the Museum is botanical rather than economic, and is sadly in need of enlargement. In the alterations of Igr $\mathrm{I}$ to the building, a new and more commodious means of access has been constructed in the place of an awkward spiral stairway of iron-an improvement which will, let us hope, both increase the utility and further the development of the Museum.

\section{THE LIBRARY}

They read Botanic Treatises,

And Works on Gardening thro' there,

And Methods of transplanting trees

To look as if they grew there.-Tennyson.

The condition of the old Library about the year 1695 was described by Celia Fiennes in her diary, recently printed under the title of "Through England on a Side Saddle." We 


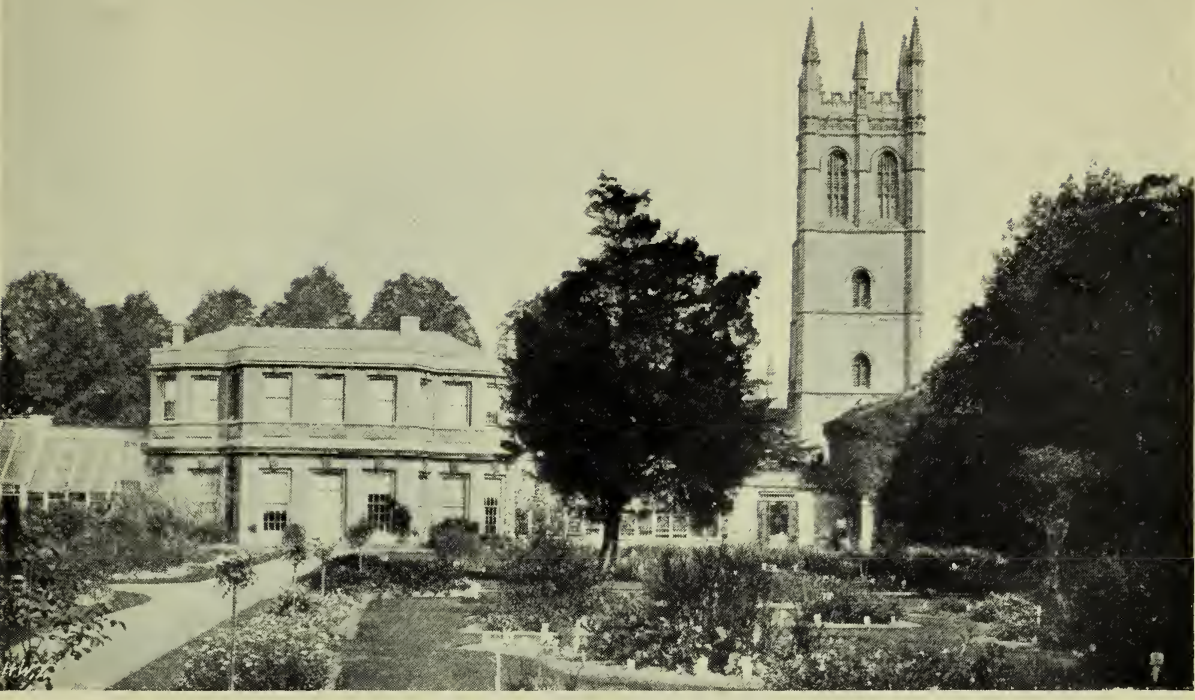

No. I

No. 2 Greenhouse

c. 1859

THE MUSEUM AND LABORATORY, I $8+8-79$

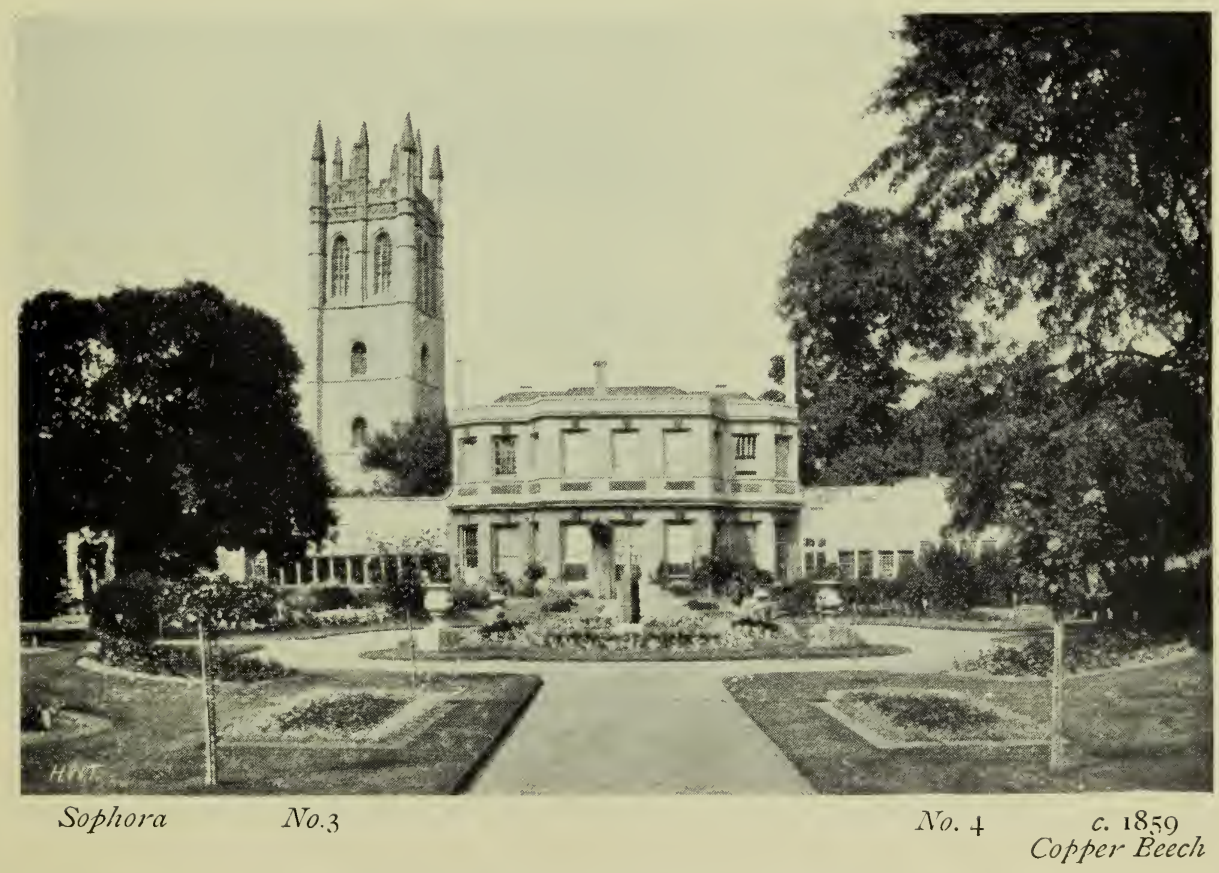

THE PROFESSOR'S HOUSE AND LIBRARY 


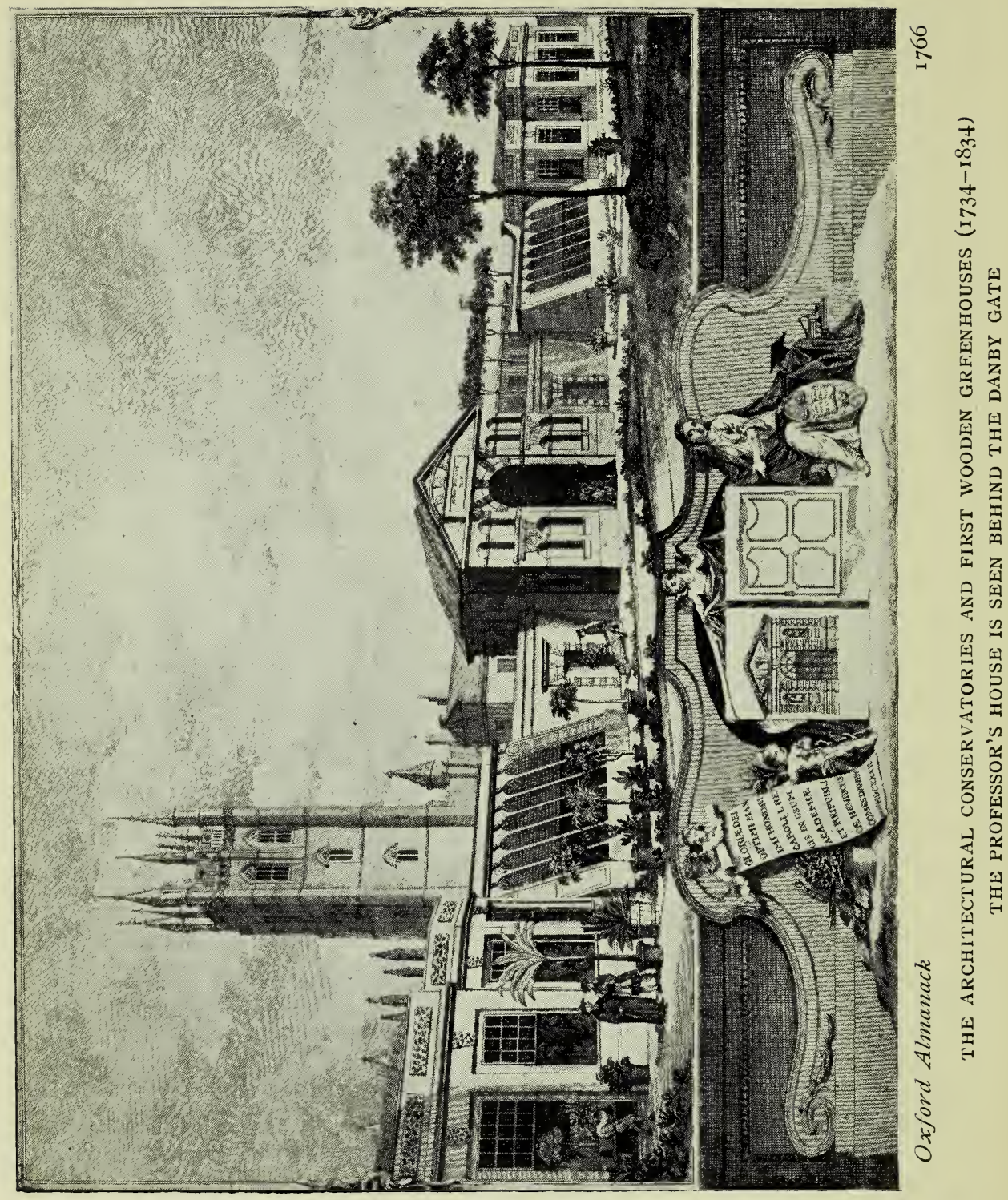


believe that the apartment which she visited was on the firstfloor above the Conservatory on the High Street, in the building also known as the Professor's House (pp. 162-3).

"The library is as large as 2 or 3 roomes but old and a little disreguarded except one part $w^{\text {ch }}$ is parted from the rest wansecoated and fitted up neate and painted which was done by King james $\mathrm{y}^{\mathrm{e}}$ Second $\mathrm{w}^{\mathrm{n}}$ he designed Maudling Colledg for his priests A Seminary."

When the house of the Professor of Botany was pulled down in 1795, in order to widen the approach to Magdalen Bridge, the East Central Conservatory was converted into a Library, Herbarium, and Lecture Room, and was for forty years the only apartment at the disposal of the Professor for private study or for public instruction. In I 834 the Library consisted of about 1,900 volumes, comprehending the following valuable collections of books :

\begin{tabular}{|c|c|c|}
\hline onsul Sherard's & ", & ," \\
\hline ohn' Sibthorp's & ", & $"$ \\
\hline
\end{tabular}

And to these, Dr. Daubeny's botanical library was added in 1868. The whole library was classified by one of the Bodleian assistants a few years ago, and it is probably the best arranged and most handy library of reference in Oxford. The library assistant, Mr. H. Baker, is always helpful to readers.

Among the especial treasures in the collection we must mention the MS. Pinax of Dillenius and Sherard, which occupied 446 packages, divided into II books and I16 sections. The death of Sherard prevented the publication of the results of so many years' patient labour, and the lapse of time has seriously detracted from its value. Still it remains - a monument to industry. The library also contains the valuable drawings of the Animals of the Levant executed

* We would suggest that each of Bobart's books should be marked with a bookplate copied from the engraving, No. 2, described on p. 5 . 
for Dr. Sibthorp by his travelling companion and draughtsman, the celebrated Ferdinand Bauer.

Oxford is also indebted to Dr. Sibthorp for one of the only two copies ever struck off from the plates engraved by order of the Emperor from the celebrated MS. of Dioscorides, with illuminated figures, preserved in the Imperial Library at Vienna. The MS. is said to have been copied at the expense of Juliana Anicia, daughter of the Emperor Flavius Anicius Olyber, about the year 492. Our copy contains 410 figures of plants, to which Dr. Sibthorp has attached the Greek names. A similar and still earlier MS. exists in the Library at Naples.

The books in the Sibthorpian Collection, which deal more particularly with the agricultural side of science, were removed to the School of Agriculture at St. John's College in 1907, for the edification and enjoyment of our Sibthorpian Professor of Rural Economy.

Against the railing of the gallery are suspended portraits in oils of Robert Morison, Dillenius, Linnaeus, Fairchild (from the Ashmolean), Sibthorp, Daubeny, and another passing as "Bobart," but not a bit like his description. An unknown portrait against the west wall may be of Sherard. There are also numerous engraved portraits of botanists and some views of local interest. 


\section{LECTURE ROOMS AND LABORATORIES}

'Twas primarily founded for a Nursery of Simples and that a Professor of Botanicey should read there, and show the use and virtue of them to his Auditors.-Wood.

Sine experientia nihil sufficienter sciri potest.-R. BACON.

Botany classes, like everything else, have their periods of maxima and minima. The King's Botanic Professor for his ¿40 was to read, not according to statute, but at such time as he thought most proper-that is, in Spring and Autumn. Dr. Morison was well attended in the open air.

According to Dr. Tatham* (1810)-

"The Botanical Lecture, which possesses every advantage that very munificent benefactions can bestow, I have known attended some years ago, before this chilling Statute [the Public Examination Statute] nipt all the shoots and blossoms of good learning, by a most respectable class of more than sixty persons. It has, however, so much dwindled and declined, that some years the Professor has not of late been able to muster a class at all; and when he has been so fortunate, that class has not amounted to a third of that number : although he is able and diligent, and has made a most liberal sacrifice of the lucrative profession of a Physician to this Academical Office of Professor of Botany; after the example of his very learned and public-spirited predecessor [Sibthorp], who was so devoted to that useful and delightful branch of learning, that he increased the stipend by a liberal benefaction."

Dr. Daubeny drew well when he lectured on Agricultural Chemistry, but only scantily with his Geographical Distribution of Plants $\uparrow$; but among the few students was John Ruskin.

* Tatham, E., "A new Address to the Free and Independent Members of Convocation." Oxford, I8ro.

$\dagger$ At a somewhat later period "We had, it is true, a Professor of Botany, but he might have resided at Botany Bay for anything we saw or knew of him" (S. R. Hole of B.N.C., 1840-44). But the impression 
Dr. Daubeny, finding the Library unsuited for herbaria books and lectures, moved the former into the Central Western Conservatory and lectured in the Magdalen College Lecture Roon, built by him in 1848 .

After his death, lectures were given in the Fielding Herbarium, as the Western Conservatory was then called, and this sometimes caused injury to the specimens.

An interesting survival of this period may be seen in the University Accounts of the present day, where the large balance-sheet of the present Botanical Laboratory appears under the somewhat inadequate title of "Fielding Herbarium."

Laboratory teaching of biological science is only of modern growth in Oxford. Dr. Daubeny had already made a beginning, by showing some slides of vegetable tissues, "made in Germany," to his classes. For students of medicine, chemical laboratory and dissecting-room had sufficed for a long period, and it was not until quite recent times that the value of thorough training in practical microscopic methods and results was fully realised. Students of biological science had to depend almost entirely upon their lectures and upon inspection of collections and apparatus. Opportunities for experimental training did not exist. From I86I onwards, George Rolleston, the Linacre Professor of Physiology, had regular classes for practical instruction in comparative anatomy at the New Museum; but botanical teaching still proceeded on old lines.

Among the earlier attempts to raise the standard were the original Regulations of the National Science Board of 1872 , superseded some ten years later. In the summer of 1873 , Professor Lawson advertised lectures on Structural, Systematic, and Economic Botany, and in the following year commenced

conveyed by the Dean of Rochester's note is certainly very erroneous, for in the forties and fifties we are surprised at the variety of subjects, botanical and agricultural, upon which Dr. Daubeny held forth in his lecture-room "contiguous to the Botanic Garden." 
a course of thirty lectures in conjunction with the Biological Departments of Exeter and Magdalen Colleges,* followed by two hours' practical work for "Dissections" and "Experiments in Vegetable Physiology."

In October, 1874, a comprehensive botanical course was arranged, comprising eight lectures on the Lower Cryptogams in Michaelmas 'Term, eight on the Higher Cryptogams in Lent Term, and twenty-four on Phanerogams in the Summer Term; but the lectures do not appear to have been well attended, and were supplanted in the Summer 'Term by a most successful biological course, which, as Sir Ray Lankester informs me, was very popular.

Deficiencies in the older professorial courses of instruction had been felt so acutely, that in April, 1875, biological teaching according to newer methods of practical microscopy was given by Professor Lawson and Mr. Lankester of Exeter College in the Herbarium at the Botanic Garden.

The lecture hour was from ro to I I a.m.; the laboratory work from II a.m. to I 2.30 p.m., and from I. 30 to 4 p.m. every day. The fee was the very moderate one of two guineas. The following is an outline of the subject-matter of the lectures, and an enumeration of the types, whose structure and (where possible) life-history the student was enabled to examine in actual specimens provided for the purpose :

Plants. Class i.: Algae. I. Palmella, 2. Protococcus, 3. Volvox, 4. Nostoc, 5. Oscillatoria, 6. Bacterium, 7. Closterium, 8. Bacillaria, 9. Zygnema, ro. Vaucheria, I I. Fucus, 12. Ceramium.-Class ii.: Fungi. 13. Torula, 14. Penicillium, I5. Aethalium (plasmodium), I6. Ascophora, 17. Peziza, 18. Agaricus.-Class iii.: Muscales. 19. Marchantia, 20.

* To these Combined College Lectures, in Michaelmas, I8;3, Mr. Lankester contributed an "Introduction to Biology - the Study of Homologies" at Exeter College, while Mr. Chapman lectured on "The Chemistry and Physiology of the Albumens" at the Magdalen Laboratory. In the next year, I874, Mr. Chapman lectured on "The Comparative Anatomy of Vertebrata," and Mr. Yule gave a series of practical demonstrations in Experimental Physiology. 
Funaria.-Class iv. : Filicales. 21. Pteris, 22. Selaginella, 23. Equisetum. -Class v. : Gymnospermae. 24. Pinus.-Class vi. : Angiospermae. 25. Poa, 26. Scilla, 27. Arum, 28. Chamaerops, 29. Orchis, 30. Euphorbia, 31. Primula, 32. Taraxacum, 33. Heracleum, 34. Rosa, 35. Dianthus, 36. Ranunculus.

Animals. Sub-kingdom i.: Protozoa. I. Gregarina, 2. Actinophrys, 3. Spirostoma, 4. Vorticella.-Sub-kingdom ii. : Coelenterata. 5. Hydra, 6. Cordylophora, 7. Spongilla, 8. Actinia.-Sub-kingdom iii.: Vermes. 9. Planaria, 10. Taenia, I I. Rotifer, 12. Lumbricus, 13. Ascaris.-Subkingdom iv. : Echinodermata. I4. Uraster, 15. Echinus (shell).-Subkingdom v.: Mollusca. 16. Plumatella, 17. Limnaeus, 18. Anodon, 19. Sepia.-Sub-kingdom vi.: Arthropoda. 20. Astacus, 2 1. Apus, 22. Blatta, 23. Scorpio, 24. Limulus.-Sub-kingdom vii.: 25. Stages of the common Frog, 26. Amphioxus, 27. Ascidian Tadpoles, 28. Lamprey, 29. Dog-fish.

This course was intended not only to provide for the student who meant to take Honours in Biology in the Natural Science School, the general survey of the structure of both plants and animals which is the necessary preliminary to a more detailed study of Anatomy and Physiology, but was also open to other students who were not preparing for examination in the subject.

In the following year the course-with a few minor alterations in the list of types-was repeated, and the practical work was done in the large "greenhouse in the north-west corner of the Garden (site of r9 I Lecture Room), which Lawson cleared out and made into a delightful room for the practical class." Sir Ray Lankester, who has so kindly written to me on this point, writes: "I drew up with Lawson printed schedules of each day's work, and I had a very stiff time-as it was my first year at University College, London. I lectured there in the Summer Term three days a week and three days a week in Oxford at the Botanical Gardens, followed by a whole day's practical work. Lawson took the other three days. The Plasmodium of Aethalium was obtained by me at Abingdon-Iawson and I went over to get it-and it was a lovely sight!" 
In the winter terms of $1876-7$ the new buildings (p. 28) not having been completed, Professor Lawson was unable to give his advertised lectures on Vegetable Histology, but he joined with Messrs. Yule and Chapman in delivering a course of Saturday evening lectures to artisans in the Magdalen Laboratory; he chose Vegetable Physiology as his subject. In the later seventies Professor Lawson advertised lectures at the Professor's House.

However, by 1879 the Lecture Room had been refitted, and two Laboratories were built on the site of two old greenhouses (Nos. I and 2), one at each end of the Lecture Room. The Western one was the Class Room, capable of accommodating twenty students; the Eastern one, a small Laboratory.

When Professor Lawson resigned his Professorship at the end of I882, his duties were taken by Mr. Chapman, who lectured in the Magdalen Laboratory and superintended the practical work. During Lent and Summer Terms, I 883, he conducted a Practical course on Elementary Vegetable Morphology, and in Michaelmas, I883, and Lent, I 884, he lectured on Vegetable Histology--in fact, he kept things going until the new Professor had been elected (see p. 29). A long series of microscopic preparations made at that time shows that the Histology of Higher Plants was also studied, perhaps in as great detail as it is in elementary classes at the present day. In the Magdalen Laboratory, too, a little later, Professor Burdon-Sanderson, assisted by Dr. Gotch, carried out his researches on Venus' Fly 'Trap, Dionaea, there being then no suitably furnished Botanical or Physiological Laboratory connected with the University.

Lawson's Laboratories and Lecture Room remained very much in statu quo, except that the Fielding Herbarium was removed into the Professor's House, leaving the Central Western Conservatory as Lecture Room only. But in October, I9II, Professor Vines changed the places of Lecture Room and Western Laboratory, so that the former was moved to the 
extreme north-west corner of the Garden, and the two Laboratories came to be next door to one another, with considerable gain of space and convenience.

At the same time a new Laboratory building of bad architectural proportions, * and overtowering the old Danby Gate in a manner that never would have been permitted by the better taste of the Fellows of Magdalen of 1876 , was erected north of the wall, on the site of a wretched little study which had been the Professor's only private room in the building.

The new building provides physiological and photographic rooms on the ground floor, while above is a fair-sized Laboratory with north light, and charming rooms for the Professor and Demonstrator. The new staircase should lead to the improvement of the Botanical Museum, which has thus been made reasonably accessible for the first time.

This is not the place in which to criticise the scientific value of the researches which have been undertaken in the old Laboratories of the Botanic Garden, but some idea of their scope may be gleaned from a list of papers describing them.

If we had to make a selection of the most important, we should mention the Professor's physiological researches on digestive processes, and Dr. Church's fine morphological studies of plant-form, to the mastery of which he has brought a combination of scientific accuracy and artistic skill that has rarely been approached, and that will appeal to all disciples of Goethe, the Father of the science of Morphology. The reproduction of his drawings, however, by the Clarendon Press, leaves much to be desired.

* This building has reminded us of Dodgson's uncompleted Syllogism in "Celarent" on the new belfry at Christ Church :

The Governing Body would conceal this appalling structure, if they could;

The Governing Body would conceal the feelings of chagrin with which they now regard it, if they could; 
List of Papers and Reports on the Results of ReSEARCHES WHOLLY OR PARTIALLY CARRIED OUT IN THE BOTANIC LABORATORIES

All references are to volumes and pages of the Annals of Botany unless otherwise stated:

1887. Schönland, S. The Apical Meristem in the Roots of Pontederiaceae. i. I79.

1888. Schönland, S. On the Morphology of the Mistletoe, Viscum album. ii. 283 .

" Vines, S. H. On the Relation between the Formation of Tubercles on the Roots of Leguminosae and the Presence of Nitrogen in the Soil. ii. 386.

„ Farmer, J. B. On the Development of the Endocarp in Sambucus niger. ii. 389 .

I889. Vines, S. H. Contribution to the Morphology and Physiology of Pulpy Fruits. iii. 393.

I890. Vines, S. H. On Isoetes lacustris. v. 37.

1891. ", , On the Presence of a Diastatic Ferment in Green Leaves. v. 409.

1892. Farmer, J. B. On the Embryogeny of Angiopteris erecta, Hoffm. vi. 265 .

I893. Farmer, J. B. On the Relation of the Nucleus to Spore Formation in certain Liverworts. Proceedings of the Royal Society, liv. 478.

,, Groom, P. On Dischidia rafflesiana. vii. 223.

, , , , The Aleurone Layer of the Seed of Grasses. vii. 387 .

I895. ", , On a new Saprophytic Monocotyledon. ix. 45.

" , , , On Thismia aseroe (Beccari) and its Mycorhiza. ix. 327.

, , , , , Contributions to the Knowledge of Monocotyledonous

Saprophytes. Journal of the Linnean Society, xxxi. 149.

, Church, A. H. The Structure of the Thallus of Neomeris dumetosa, Lamour. ix. $5^{8}$ I.

I896. Groom, P. Preliminary Note on the Relation between Calcium and the Conduction of Carbohydrates in Plants. x. 91 .

, Vines, S. H. Demonstration of Root Pressure and Transpiration. X. 291.

Vines, S. H. The Suction Force of Transpiring Branches. x. 429 .

1897. Groom, P. On the Leaves of Lathraea squamaria. xi. 385.

,, Vines, S. H. Proteolytic Enzymes of Nepenthes. xi. 565. I 898 . 
I898. Church, A. H. The Polymorphy of Cutleria multifida. xii. 75.

,, Ewart, A. J. Action of Cold and Sunlight upon Aquatic Plants. xii. 363 .

„, Ewart, A. J. Action of Chloroform on $\mathrm{CO}_{2}$-assimilation. xii. $4 \mathrm{I} 5$.

I899. Sturch, H. H. Harveyella mirabilis. xiii. 83 .

190I. Church, A. H. Note on Phyllotaxis. xv. 48 I.

, Vines, S. H. On Leptomin. xv. I81.

$\begin{array}{ccll}\text { I902. } & , & , & \text { Proteolytic Enzymes of Nepenthes. xv. } 563 . \\ \text { I903. } & , & \text { Tryptophane in Proteolysis. xvi. I. }\end{array}$

, Ewart, A. J. On the Physics and Physiology of Protoplasmic Streaming in Plants. 8vo. Oxford.

1904. Church, A. H. The Principles of Phyllotaxis. xviii. 227.

1904 Vines, S. H. The Proteases of Plants, I. xviii. 289; II. xix. I 49;

to III. xix. I7I ; IV. xx. II3; V. xxii. IO3; VI. xxiii. I ; I9I0. VII. xxiv. 213.

I904. Church, A. H. On the Relation of Phyllotaxis to Mechanical Laws. 8vo. London. I. Orthogonal Trajectories; 2. Symmetry and Asymmetry; 3. Secondary Growth Phenomena; 4. Mathematical Notes.

1908. Church, A. H. Types of Floral Mechanism. Part I. 4to. Oxford. 1909. Boodle, L. A., and Hiley, W. E. On the Vascular Structure of some Species of Gleichenia. xxiii. 4 I 9 .

\section{THE PROFESSOR'S HOUSE}

May I a small house and large garden have,

And a few friends, and many books, both true.-Cowley.

There have been at least four Professor's Houses in the history of the Garden, without counting the little turret-room, shown on Loggan's map, p. 7 , on the wall to the west of the main gate.

The earliest stood north of the wall, and is shown in Loggan's plan, 1675, but not in later views. The elder Bobart died there in 1679 .

The second was built upon the site, and perhaps on the walls, of the first conservatory for tender greens, on the street. It was probably the one which had served as the Library of r695, vide supra, and was the one referred to by Ayliffe: 
"In I 7 4 Bobart had a very handsome house, lately built for his Use at the expence of the University; where he attends Courses of Botany, if any Persons are so curious as to study and go thro' the same." The large sums of money which were spent by the University on the Garden between 1692 and 1696 (stated in detail in the section on Finance, pp. $175^{-6}$ ) probably included the cost of this house. A view of the top of this, the Old House as it was called, appeared in the Oxford Almanack for 1766 , as shown in our view facing p. I 53 . It stood on the street, at the foot of the bridge.

In the seventies, plans for the construction of a new house were contemplated, and James Wyatt, the architect, went into the matter in $\mathrm{I} 775$; but whether or not the house, actually built with the aid of the grant made by Convocation in 1776 , was entirely planned by him, is not certain. An advertisement inviting tenders appeared in Jackson's Oxford Journal for March 23, 1776.

Meanwhile, the foundation-stone of the new Magdalen Bridge had been laid on March 26, I 773, and when the bridge was finished, the approach was found to be not wide enough. Either the new Professor's House ${ }^{*}$ or Magdalen Tower obviously had to be moved.

* Good views of the Professor's House have been published by Malchair in "A view from St. Clements of Magdalen Bridge, before it was taken down in 1772 "; also in the Oxford Almanacks for I77I, reproduced as plates 123 and 124 by Skelton; also by Buckler in his "View of Magdalen College from the South-east," and in the "Entrance to Oxford by the London Road." It is no longer seen in a similar view of Magdalen Tower and Bridge published in the Oxford Almanack for I 797.

In 1797 the Oxford Paving Commissioners paid to Magdalen College $£ 94$ for the purchase of $12 \mathrm{ft}$. added to the street and for loss to the College by the pulling down of houses which were under lease. The land opposite to the College was enclosed in I8I9 by an iron railing similar to that in front of the Physick Garden. The last notice of the house was a credit of $£ 299$ I7s. $4 d$. paid by the Street Commissioners for the materials of the Old House, which appeared in a Garden Improvements Balance Sheet for Nov. 2, I 835 . 
"We are now taking down the Physic Garden House and Library; i.e. the botany Professor's House and botanic Library, (tho' both new buildings), to make room for the approach to the bridge from the town" (Letter from Daniel Price of February I0, I790).

Sibthorp was the Professor at the time; and, anxious to reside as near to his work as possible, moved over the new bridge into a house in Cowley Place.*

This move was an irreparable calamity to the Garden.

With Professor went books, papers, and collections. They remained at Cowley Place during his second tour in Greece, and when he returned with his new collections after the disastrous journey home in I 795 , he was too ill to put anything in order. To make a sad story short, a few printed books were procured for the University, but Sibthorp's irreplaceable manuscripts and letters of supreme interest went partly to a paper-mill, partly to wrap up the wares of the petty tradesmen of the neighbourhood.

* A good story about this house is told by Cox in his "Recollections." Dr. Sibthorp built what is called "Cowley House" (being in the parish of Cowley), merely separated from the Botanic Gardens by a meadow and a stream. It was said that he intended it as a residence for his successors ; the gift, however, was never made. The house is said to have been built of bricks made of clay upon the spot. Dr. Sibthorp in some measure spoilt its arrangement and proportions in order to accommodate a fine staircase and some large windows which he had purchased at the pulling down of Lord Abingdon's house at Rycot, near Thame. The building itself certainly has no pretension to external beauty, notwithstanding its fine situation: Dr. Sibthorp, nevertheless, the admirer of his own creation, appears to have thought otherwise; for he is reported to have asked the Dean of Christ Church for a Studentship for one of his family, on the ground of having built "so beautiful and classical a terminus to the vista of the Broad Walk!" "A Studentship!" replied Dean Cyril Jackson. "My good Sir, I will give you two if you will be so kind as to pull it down again."

Cox's other story about the lecture on nettles, I have always heard told of Dr. Daubeny. (See p. 8I.) 
Much may depend upon an official residence; and Dr. Daubeny knew what he was about when he built the fourth and last Professor's House in 1835 . The building is still standing almost as he left it, with its Cave Canem painted upon Neapolitan tiles inlaid in the threshold. It has been uninhabited for thirty years, notwithstanding that one of the advertised amenities attaching to the Professorship is that this residence, on the banks of the Cherwell, with five acres of garden and an unrivalled view of Magdalen Tower, is "rent-free!"

\section{THE EXPERIMENTAL GARDEN}

Yet say the neighbours when they call

It is not bad but good land, And in it is the germ of all

That grows within the woodland.-TENNYSON.

During the first years that Dr. Daubeny had care of the Garden, a portion of ground outside the East Wall was set apart for experiments connected with vegetable physiology, and its applications to agriculture. A plan of this ground, showing the disposition of the crops, was printed in the first edition of the Garden Guide in $185^{\circ}$.

The Garden soil was carefully analysed (an operation which has probably not been repeated since) and its capability for growing standard crops tested. The most important experiments made there, with the assistance of the Daubeny Laboratory, proved-

I. That plants only contain the mineral ingredients which are supplied to them by the ground, and hence that the quantity of their earthy contents is determined by the chemical composition of the soil in contact with their roots, although its quality will depend upon the plant itself, those ingredients which are uncongenial to it being excreted,-Linnean Transactions, 1833 . 
2. That plants give out more oxygen during the day than they absorb at night.-Philosophical Transactions, 1836.

3. That the more luminous rays of the solar spectrum are especially instrumental in stimulating the vital energies of plants, thus causing them to absorb moisture by their roots, to exhale it from their leaves, and to emit oxygen through the decomposition of carbonic acid gas.-Philosophical Transactions, 1836. [Anticipation of Draper's discovery.]

4. That some of the ingredients of a soil are active, whereas others are dormant, i.e. a portion only of the mineral matter in a soil is in a condition to be taken up by a plant. Ploughing and other agricultural operations seem to be mainly of utility in promoting the gradual operation of atmospheric agents, in unloosing the dormant ingredients from their union one with the other, and in thus rendering them available for the purposes of the plant.-Botanic Lecture, 1843; Journ. Royal Agric. Soc., I 846.

5. That the rotation of crops is advantageous.-Bakerian Lecture; Philosophical Transactions, I 845.

6. That the mineral phosphates of Estremadura in Spain are most efficacious as a manure.-Journ. Royal Agric. Soc., 1846.

7. The relative utility of certain manures._British Association Reports, 1846; Agricultural Notes, 1846.

8. That ferns can subsist for a limited time in an atmosphere containing no less than 20 per cent. of carbonic acid gas, and, since the cold-blooded animals which were associated with the plants of the coal formation could in all probability also endure an atmosphere containing 50 per cent. of this gas, there is nothing contrary to probability in the supposition of M. A. Brongniart, that at this early period a larger amount of $\mathrm{CO}^{2}$ existed in the atmosphere than is present in it now.British Association Reports, $\mathbf{1} 848$.

9. That the relative proportions of potash and soda vary in barleys grown in plots artificially impregnated with these alkalies.-Journ. Chemical Society, 1853. 
Io. Another research of great interest was undertaken at the instance of the British Association for the Advancement of Science. It was the testing of the limit of the vitality of the seeds of various plants. 'This was sought to be done by sowing a few of each sort at intervals of five years, and noting whether or not any of them vegetated. A list of the seeds tried was published in the Reports of the British Association for 1848, p. 32 , and some of the seeds then collected should still be upon the premises of the Botanic Garden.

For the purposes of this investigation the seeds were kept buried under an inch of dry sand, in porous pots, the mouths of which were then covered with strong paper dipped in corrosive sublimate.

When in 1852 new glass-houses were erected on the Experimental Ground, Dr. Daubeny, aware of the importance of continuing field-work, purchased, for $£ \mathbf{1} 40$, I acre 3 roods I I poles * near the Iffley Road from Magdalen College, which he subsequently made over to the University, in trust for the Professor of Rural Economy for the time being, in order that he might have the means of carrying on inquiries connected with scientific agriculture which from time to time suggest themselves.

The Iffley Road plot was perhaps not so good a piece of land as it might have been, for the surface was not level and its condition was somewhat uneven, but, as the Experimental Notebooks show, useful observations were made there, and among the published results was the paper:

"That roots select the ingredients presented to their absorbing surfaces which are fitted for assimilation, but reject those which are either useless or noxious."-Journ. Chemical Society, $\mathbf{1 8 6 2 .}$

We believe that in all this work Daubeny had come under

* A plan of the ground, with results of experiments, is contained in Daubeny MS. Experimental and Day Books, 1848-66, in Magdalen College Library. 
the influence of Liebig, with whom he was on terms of intimate correspondence, and that both by the example of his early experiments in the Botanic Garden and by his enthusiastic exposition of the principles of the science in his lectures, he imbued one of his pupils, John Bennet Lawes, with so bright a desire to further agricultural progress by exact field experiments, that the fame of the latter's hereditary estate of Rothamsted will endure through the ages.

But although this pioneer work yielded so rich a harvest elsewhere, it is sad to have to record that, with Dr. Daubeny's death, the practical exercise of the oldest of the Arts became dormant in Oxford. Mr. Gamlen informs me that Professor Lawson used the plot for the culture of Strawberries; but I have not been able to find that the Professor published any account of the results.

Then, Sibthorpian Professors of Rural Economy were only elected for three years, and any one man was debarred, by the I 883 scheme, from holding the chair for more than six; and, as they were not allowed any funds for working allotments, the utility of Daubeny's experimental plot was reduced to a minimum. But it looked well in the advertisements to be able to state that "the Professor shall have the use of the Garden appropriated for making experiments in the subject of his Professorship." The University was not in the least interested in the art of getting better and more abundant vegetable produce from the land, and finally seized an opportunity of letting the experimental plot and cottage for E 2 per annum,* and later, in I90I, of selling it for about $£ 800$ to Mr. W. F. Cross; and thus, with the approval of the Board of Agriculture (?), a valuable lesson has been given to would-be benefactors interested in experimental agriculture. The cottage and plot are at the end of Fairacres Road-

* The transaction, we are glad to record, did not meet with universal satisfaction. The little house was known in the Magdalen Common Room as "Swindledon Villa." 


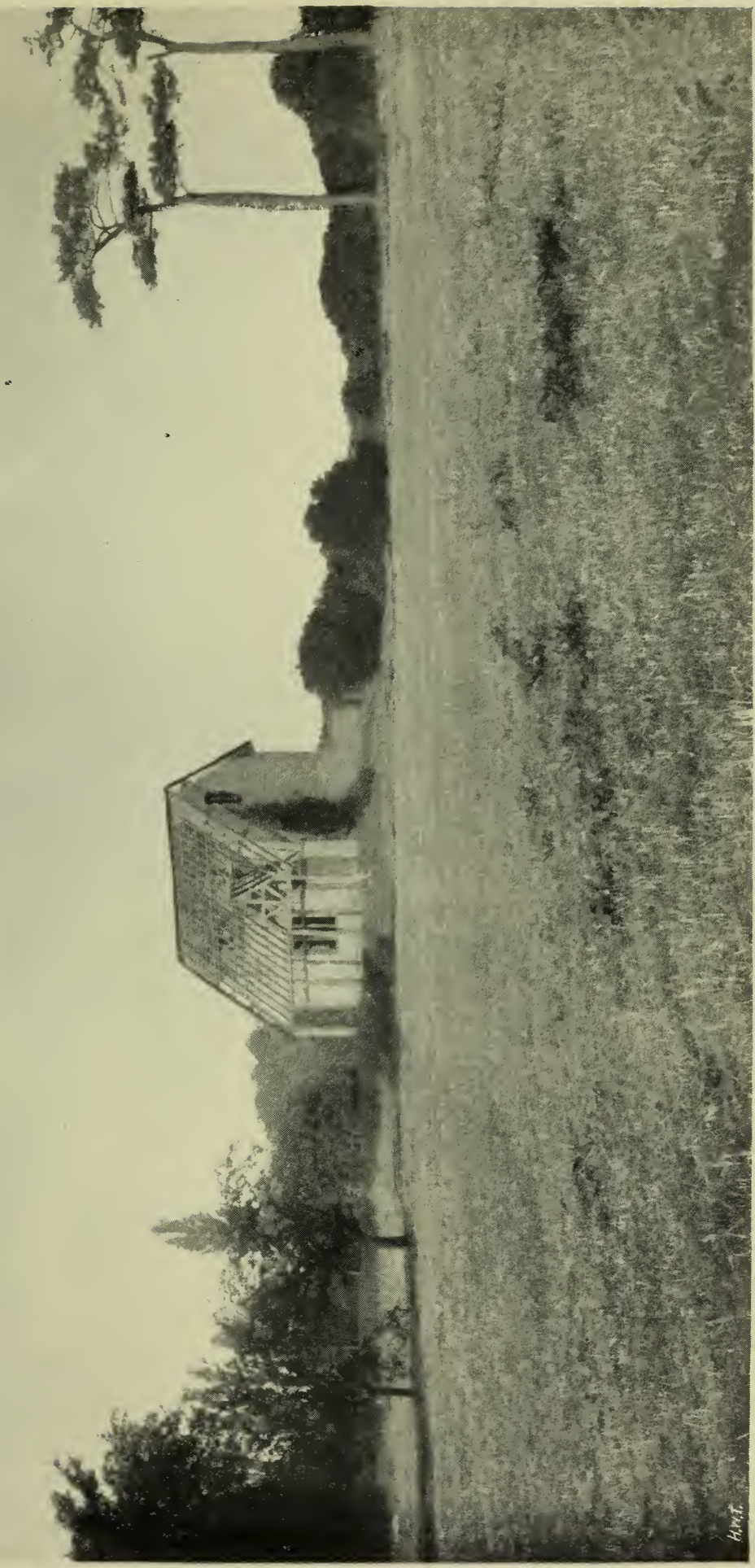

$\Xi$

年

$\dot{a}$
$\vdots$
$\vdots$ 

the former roofless, the latter pasturage run wild. All the land above has been "developed," as it is called, i.e. covered with rows of little speculative villas. Several of their small garden-paths are edged with tiles taken from the walks of the old Experimental Ground. A row of fine large fruit trees of the Doctor's planting stretches across the ground: they once shaded his walk from the cottage to the river, which runs a field or two below. Along the upper side are a few old Scotch Firs, but much cut about and broken: they are no doubt the last vestiges of a belt of trees planted to screen the ground from the easterly winds. For years, so the neighbours told me, Dr. Daubeny's plants used to come up and give pleasure to later generations.

It was a picture of the lost opportunities of half a century. In the eloquent words of Charles Kingsley, " our field may be a small field, but it is a field ; tillage is possible, a crop is possible; who can tell whither the wind may waft its seeds when the crop is ripe?" Had the opportunity been present, Oxford might have had her share in the scientific "creation" of those new wheats the wonderful qualities of which promise to raise the position of English agriculture and reflect the greatest honour on the directors of the Experimental Grounds at Cambridge.

As an undergraduate I remember how carefully the tenant had fenced himself in with barbed wire, notice boards, alarmbells on the gate, and perhaps, most effective of all, the sight of a man-trap hung upon the wall of his cottage-a curiosity which, a few years later, I could not restrain myself from acquiring.

But the spirit of scientific research is not easy to kill. For years the plot yielded guinea-pigs for the Physiological Laboratory, and with its aid George Romanes carried on experiments of far-reaching consequence upon the crossing of Himalayan with other varieties of rabbits, a research alluded to in "Darwin and after Darwin," but one which had not been concluded at the time of his early death. Romanes much wished to see established in Oxford what M. Giard has called 
an Institut transformiste, and he even circulated a memorandum urging that some garden or farm might be set aside for such studies as that of the hereditary transmission of characters (Romanes' "Life," p. 267). His scheme was given the cold shoulder, and we are now beginning to realise the opportunities which have been lost.

After fifty years we have again a resident Professor of Rural Economy. He receives some $\mathcal{2}_{20}$ a year in lieu of being expected to till his trust estate; and St. John's College has lent another experimental plot. Perhaps in a few more years our reformers will urge the College to present that land also to a University which, in a few more, will sell it - perhaps to build a hangar for aeroplanes.

\section{GOVERNMENT}

Sendo l'intento mio scrivere cosa utile a chi l'intende, mi è parso più conveniente l'andare dietro alla verità effettuale della cosa, che all' imaginazione de essa.-Machiavelli.

The responsibilities of management at first lay entirely with the Professor and with the Praefectus Horti, as the Curator of the Garden was then called. Now he is the Horti Custos, who resides in the Garden and must not be confounded with the Curators of the Garden, who are quite a modern institution, are non-resident, and who meet once a year.

On July 9, I733, the Court of Chancery ordered that a Perpetual Committee should be established to supervise and regulate all things relating to the Botanic Garden. In accordance with the provisions of Sherard's will (I728), it was to consist of the Vice-Chancellor, two Proctors, Regius Professor of Medicine, and "the seven seniors resident upon the physic line." This Perpetual Committee only lasted until July $2 \mathrm{I}, \mathrm{I} 87 \mathrm{I}$, when it was replaced, by the same Court, by a Board of Curators of the Botanic Garden, who were to be three resident Members of Convocation to be nominated by the Vice-Chancellor and Proctors, subject to the approbation of Convocation, to hold office for ten years. 
The duties of the Curators were to manage the Garden and to expend the annual University grant of $\mathcal{E} 5^{\circ}$ on Garden, Green-house, and Library. In 1884 the control of the entire Garden expenditure was handed over to them, and in 1888 the obligation of annually reporting their doings to Convocation was laid on them. The term of office of the three Curators appointed in 1876 expired in 1886 , and shortly after, their number was doubled and the present method of appointment inaugurated; two were to be appointed by the Vice-Chancellor and Proctors, two by the Hebdomadal Council, and two by Congregation, and one in each class was to retire at short intervals.

The Professor had assigned to him by the University Commissioners of 1877 the charge and supervision of the Garden, subject to any authority vested by statute in the Curators of the Garden.

The College of Physicians have visitatorial powers.

\section{List OF OfFICERS}

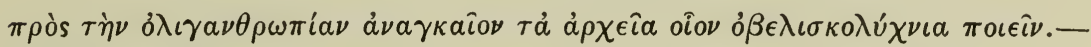
Aristotle, Politics.

PROFESSORS

Robert Morison,

Ist Danby Professor . 1669-1683

Jacob Bobart, Jun. . . I683-I7I9

Edward Sandys • 1720-1724

Gilbert Trowe . . . I 724-1734

John Jacob Dillenius,

Ist Sherardian Professor 1734-1747

Humphrey Sibthorp. • I 1747-1784
CUSTODIANS OF THE GARDEN

[John Tradescant].*

Jacob Bobart, Sen. . I632-1679

? Tilleman Bobart.

?G. D. Ehret ․ $175^{0-}-$

? James Benwell, $\uparrow$

Gardener.

* Had he lived, the younger Tradescant would have had the office (MSS. Twyne, “Archiv. Univ. Ox.," pp. 286-7) : "He (Lord Danby) came to some reasonably good terms of agreement with John Tradescant of West Lambeth, designed for the gardener, viz. for a yearly stipend of $£ 50$ or thereabouts." And not long after, the said J.T. died.

$\dagger$ An engraving, published by J. Skelton in 1817, gives his age as 82 . 
John Sibthorp,

PROFESSORS

Regius and Sherardian

Professor after 1793 *.

George Williams

Charles Giles Bridle Daubeny . . .

Marmaduke Alexander

Lawson . . . 1868-1883

Isaac Bayley Balfour . I884-I888

Sidney Howard Vines . 1888-
1784-1 795 I 796-1 834 I $834-1867$ W. G. Baker . . I888-

\section{DEMONSTRATORS}

John Bretland Farmer . $1887-1892$

Arthur Henry Church . 1894-

Wilfrid Edward Hiley 1908William H. Baxter $\neq$. $1851-1887$

CUSTODIANS OF THE GARDEN

J. Foreman . . ? -1812 William Baxter $\dagger$. $1813-1851$ CURATORS OF THE HERBARIUM William Baxter.

Maxwell Masters . circ. 1856 Selmar Schönland, Ph.D. Kiel . 1885-1890 George Claridge Druce . . 1895-

MEMBERS OF THE BOARD OF CURATORS

Edward Hartopp Cradock . . . 1876-1886

William Walrond Jackson . . . 1876-1886

§Edward Chapman . . . . 1876-1895

Robert William Raper . . . I887-I896

Aubrey Lackington Moore . . . I887-I889

Franklin T. Richards . . . . $1887-1897$

Edward Armstrong . . . . I887-

Thomas Herbert Warren . . . 1887-

Henry Jardine Bidder . • . . 1899-

§Llewellyn J. M. Bebb . . . 1896-1901

William Warde Fowler . . . 1896-

Charles Lancelot Shadwell . . . 1897-

§Cyril Robert Carter . . . . I899-1901 and 1910-

§George Edward Baker • • . 1902-1909

* King George III.'s foundation was announced in the Gazette for Jan. 8, 1793 .

$\dagger$ b. Rugby Jan. 15, I787; retired I851 ; d. Nov. I, I871 (biographical notice by G. C. Druce, "Flora of Berkshire"). An engraved portrait by $\mathrm{J}$. Whessell hangs in the Botanical Library.

$\ddagger$ Died 1890, as Superintendent of the University Parks. Obituary notice by Druce, in "Rep. Ashm. Nat. Hist. Soc.," I 903.

$\S$ Acted as Secretary to the Curators. 
A unique honour was conferred on Mr. Chapman, who, in May, I896, was constituted a Perpetual Curator by Decree. Unfortunately, soon afterwards, it was discovered that the appointment was ultra vires, and Convocation in 1898 rescinded their decree. Mr. Chapman replied to the Vice-Chancellor expressing his regret and endorsing the opinion of Mr. Bumble on the Law.

\section{Rules AND Red TAPE}

Sherard's original "Orders for the Physic Garden" show how little the man in the street was encouraged to enter the Garden in those early days. They read:

I. That no Person presume to break through, or leap over the Hedges and Fences in the Garden.

II. That no Person appear within the Quarters or close Walks of the Garden, unless the Professor or Gardiner attends on such Person during his Stay there.

III. That no Person brings Dogs into the Garden or do any Damage to the Greenhouses, Stoves, Trees or Plants, by Handling, Breaking or otherwise Defacing Them, or by Meddling with any of the Numbers.

IV. That no Person continue in the Garden after the Dusk of the Evening, but depart quietly at the usual Time of Shutting the Gates.

V. That no Person be admitted in the Garden on Sundays.

VI. That Attendance be given to such as want to see the Garden, Stoves, etc., from the Opening of the Garden Gates to the Closing of the Same.

VII. No Roots, Plants, Flowers, Fruits, Seeds, Slips, Cuttings or Specimens of Plants are to be given, sold, exchanged or taken away, without special Leave from the Professor.

Dr. Daubeny drew up a revised code of "Regulations of the Botanic Garden," dated June 29, I835 :

I. The Botanic Garden is open to Members of the University during week-days, from Sun-rise to Sun-set.

II. The principal Entrance, towards the High Street, is kept locked, but admittance will be obtained on ringing the Bell attached to the Gateway.

III. General orders have been given to exclude Nursery-maids and Children from the Premises, but every facility will be afforded for 
the admission of persons to whom the Garden may seem likely to be a source of interest or improvement.

IV. Specimens of Flowers, \&c., may be obtained from the Curator ; but it is requested that none will be plucked without special leave.

V. The Conservatories, Hothouses and other parts of the Garden which are kept locked, may be visited by applying to the Curator. VI. The Library of the Botanic Garden may be consulted during weekdays, by Members of the University, and others known or introduced to the Professor, from Twelve to Four o'clock; the Portress, who has keys of the cases, being directed to take down such books as may be required, and to see them replaced on the shelves afterwards.

VII. It is requested that, to prevent abuse, every person who avails himself of this permission, will enter his name, the place of his abode, the date of the year, and the title of the volumes which he consults, in a book kept for the purpose in the Library.

By $185^{\circ}$ Regulations VI. and VII. had been combined, the Library hours being extended first to 4 p.m. and then to 5 p.m., the Gardener was given the duties of the Curator, and a new Regulation VII. was promulgated :

VII. The Herbarium may be consulted under similar regulations by application to Mr. Baxter, Sen., who is in attendance at the Garden from 9 till 5 o'clock. (May ist, 1850.)

In 1853 the Fielding Herbarium arrived, and Regulation VII. was altered so as to read:

VII. The Herbaria may be consulted by Members of the University, between the hours of Twelve and Five every week-day during Term, and whenever the Sub-Curator is in attendance, in the Vacations. Other persons desirous of examining this Collection are requested to apply for permission to the Professor of Botany, or to either of the other Curators.

On April 3, I85 I, the Garden Committee made an order that the unpopular fee of one shilling should be demanded of those who visited the Green-houses ; and in 1856 the writer of a leaflet signed "B.D." made this an excuse for opposing the Garden grant in Convocation.

Under the present arrangements the Garden is open on 
week-days (Good Friday and Christmas Day excepted) between 7 a.m. and 6 p.m., from March 24 until September 29, and between 7 a.m. or daylight, until 5 p.m. or dusk, from September 30 until March 23.

The Library, Herbarium, and Museum are open on weekdays to Members of the University, and others between Io a.m. and 4 p.m. Admission by application to the Professor of Botany.

In 1887 the Curators sanctioned Sunday opening for the first time-a privilege much appreciated by the public. And now on Sundays (in summer only) the Garden is open from mid-day until six o'clock.

The Green-houses are open free to the public on week-days between the hours of 2 and 4 p.m., and the only restrictive notice states that

Dogs are not admitted.

Visitors are requested not to gather the flowers or seeds.

Children are not admitted unless in charge of a responsible person.

By Order of the Curators.

\section{Finance}

"And, finally, as the College authorities live secluded from the world, and so are like children as to commercial matters, I would advise them to consult ..."-RHODES.

\section{EARLY BILLS}

I660-I. William Bird for mending King's and Founder's Arms over the Gate . 1685-90. Burgesse $[=$ Burghers $]$ for engraving $\}. .62$ II $\quad 0$ plates for Morison's 2nd vol. $\}$ • 9 i 776 For 4 plates . . . . 10 130 ,, 10 , . . . . . 27 18 , I plate. . . . . 2180

1692-3. Young, the smith, for work at the Garden, St. Mary's, and the Library . 
EARLY BILLS (cont.)

6 s. $d$.

I692-3. Robinson, a mason . • • • . . . . 3959

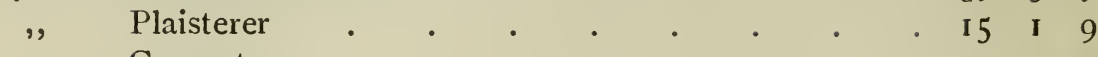

, Carpenter . . . . . . . . . $4 \begin{array}{lll}4 & 15 & 5\end{array}$

1693-4. Young, the smith . . . . . . . . I4 0

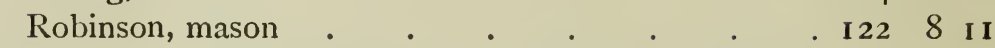

I694, October. The avenue leading to the Garden was finished at the charge of the University.

1694-5. Vanderstene, carver . . . . . . 26 Iо o

, Robinson, including work at St. Mary's and at the

Printing House . • • . $\quad$. $\quad \begin{array}{llll}54 & & \text { I }\end{array}$

, Geo. Smith, carpenter, including work at St. Mary's and at the Printing House . $\quad$. $\quad \begin{array}{llllll}56 & 9 & 7\end{array}$

,, Plaisterer, including work at the Printing House . $\begin{array}{lll}\mathbf{I}_{3} & 7 & 0\end{array}$

, Painters . . . . . . . . . I I 76

1695-6. Mason • . . . . . . . . 33137

John Vandersteen, carver, for cutting the Earl of

Danby's statue and for other work . . . 7 I2 o

The heavy payments made from I 692 to 1696 were probably for the new house for Professor Bobart, as well as for the " new herb house" (p. 92).

To completely unravel the intricate Accounts of the Garden would probably be a task beyond our powers, even if the materials for such a research were forthcoming.

The difficulty lies in the frequent confusion of the stipend of the Sherardian Professor with the budget of the Physic Garden, and in the fact that sometimes Professors have helped to support the Garden with their salaries, at others they have looked to Garden funds for their own maintenance.

Frequent have been the protests of Professors against the alleged illegal practice of charging Garden repairs to the Sherardian Fund; and even now it is doubtful whether the accounts have been squared up fairly.

We will for a moment confine ourselves to a few statements concerning the financial position at various epochs.

It is our own pious opinion that the founder, Lord Danby, died in the belief that the proceeds of the Rectory of Kirkdale in Yorkshire would serve for the upkeep both of Garden and 
Professor. The bequest took effect in 1659 , and in 1669 Convocation elected the first Professor, Dr. Morison, assigning him the small stipend of $£ 40$ a year. It is said that no successor was elected by Convocation.

In I 734, in compliance with a condition in Dr. Sherard's will, an annual payment was made of $£^{1} 5^{\circ}$ for the maintenance of the Garden.

In 1793 King George III. granted the sum of $£_{200}$ yearly, which was reduced by fees of office to $£_{182}$, half to augment the stipend of the Professor, and half towards the maintenance of the Garden. This sum, since the remission of certain stamp duties in 1855 , is paid from the University Chest.

After Lord Danby had bought out the original tenant, Ellis by name, Magdalen College leased the Garden to the University for the annual payment of the corn rent, the quit rent, and a nominal fine at each renewal of the lease, which took place every seven years.

The original rent for the use of the Garden was 40 s. per annum, and from 1650 to 1697 the rents and fees continued to average this sum. Later, the lease was for a period of forty years, renewable every fourteen years at a small reserved rent.

In 1855 the University paid to the College :

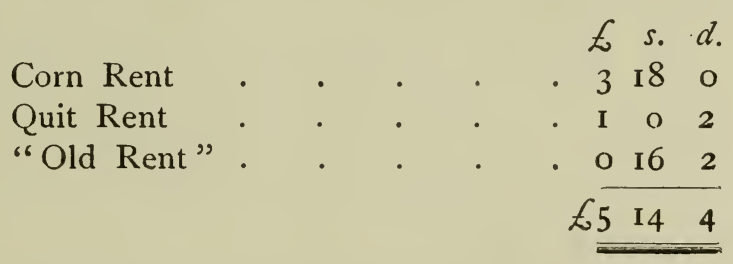

and the total rates and rent came to $£ 403$ s. $3^{d}$.

Full accounts for 1870-I were submitted by Professor Lawson to the University Commission and were printed with theirReport.

In 1876 Magdalen College granted and the University accepted a new lease for sixty years at a rent of $£ 30$ per annum, on three conditions: Firstly, that the University should lay out $£ 5,580$ on repairs and new buildings; next, 
that the College should have the veto on all removal of trees and on the erection of buildings, temporary or permanent, which they might consider unsightly or prejudicial to their property ; and thirdly, that the lease should terminate absolutely whenever the land shall cease to be used as the principal Botanic Garden of the University.

In pursuance of this covenant the University forthwith spent $£$ 2,200 upon the Wall and the Lecture Room, and built the Class Room and small Laboratory adjoining, on the sites of the dilapidated Western Green-houses (University Gazette for May 22, I876).

In later years the University Accounts tell a monotonous story of a continual making up of the deficits in the accounts of the Botanic Garden, relieved by occasional votes of larger sums of money for building.

Thus, in $1893, £ 3,500$ was asked to cover expenditure estimated at $£ \mathrm{I}, 400$ in $1893, £_{542}$ in 1894 , and $£ \mathrm{I}, \mathrm{II} 2$ in I895. Large sums were also spent for Botany elsewhere, for in $1898 £ 7,500$ was voted for a Joint Laboratory and Lecture Room for the Botanical and Comparative Anatomy Professors upon a site so remote from the Garden that the joint scheme can only be regarded as a makeshift arrangement.

Again, by the munificence of St. John's College, in 1907-9 an Institute of Applied Botany (Rural Economy) was built at a cost of $£ 8,159$ I2s. $7 d$., not counting the value of the site.

And during the presènt year an expenditure of over $£ 3,500$ has been incurred for improved Laboratory accommodation at the Botanic Garden itself.

In I903 Magdalen College, of its own free will, and out of a wish to benefit the University at a time of stress rather than to aggrandise itself, and notwithstanding the increased value of land in the City of Oxford, reduced the rent from $\mathcal{E}_{30}$ to Ios. per annum, at which figure it now stands. At present the other rents paid are one of $5 s$. to the Oxford Corporation and one of $6 d$. to Christ Church, so that the University 
cannot be said to be over-rented for its Garden; the total rent being ${ }^{5} 5$. $6 d$.

It has been computed that the total cost of the upkeep of the Garden to the University for the years i650 to I8I 2 was $£$ i 9,43018 s., $\ell_{7}, 6087 s$. $1 d$. of which was received from Kirkdale, the Danby Benefaction.

At the present time the total income of the Botanic Garden and "Fielding Herbarium" is $\mathcal{E} \mathrm{I}, 095$, of which $\mathcal{L}_{452}$ is from trust funds and $\mathcal{E}^{25}$ is from a donation from Professor Vines.

Under the misleading and antiquated term "Fielding Herbarium" larger accounts lie perdus, for it includes the Library and its staff (Books and Binding alone cost \& I47), as well as the Botanical Lecture Rooms and Laboratories, with the Demonstrators and Assistants therein employed. For the use of Laboratories and Lectures, students contributed in I9 Io, directly or indirectly, no less than f6I4 , and yet the Fielding Herbarium, sensu stricto, was a closed book to them. Again, the indebtedness of students to the Garden is assessed at $£ 75$ per annum. It seems a lot to pay for a few flowers for dissection! The money might be used for renewing or for improving laboratory equipment, or for reducing the fees payable by students; and in any case such a payment to the Garden should not be necessary.

The present income of the Garden, apart from that of the Laboratory, Library, and Herbarium, brought, by a grant voted by the University, up to $\mathcal{L}_{670}$, would have seemed affluence in days of our predecessors, but nevertheless the accounts have been for many years in debit. The Chairman of the Curators reported in 1902 that expenses were kept down to starvation point, that the painting and maintenance of the houses were not adequately provided for, and that any unforeseen increase of expenditure, as might be occasioned by a rise in wages or a prolonged and cold winter, would mean increased debt.

But the real question for the Curators to answer is, Is it 
not the first duty of a great University Department to conduct its business so as to avoid the reproach which attaches to any private individual who lives above his income?

\section{EXTRACTS FROM THE VISITORS' BOOKS}

1621, July 25. William Piers, Vice-Chancellor [p. 2].

," $\quad$ Edward Dawson, a Cambridge physician who incorporated at Oxford [p. 2].

Dr. Thomas Clayton, Regius Professor of Medicine [p. 2].

1654, July I2. John Evelyn and his wife.

1664. Sorbière, a French physician [p. I I].

Oct. 24. John Evelyn and (?) Lord Cornbury.

I668, June 9. Samuel Pepys.

1669. Elias Ashmole [p. 6].

,, May 4. Cosmo de Medici, Grand Duke of Tuscany, who lodged at the Angel, just within the East Gate, "went and saw the Phisick Garden (Bobard the keeper having presented him with a very fine nosegay in the morning) and being there come the said Bobard spake a speech in the German tongue to him, which he liking * and his garden, he gave him a reward" (Wood, "Life and Times," edit. Clark).

Not all visitors were so polite, for Mark Coleman, "a melancholy distracted man, sometime a singing-man of $\mathrm{Ch}$. Ch., walking in the Garden caught fast hold of J. Bobart senr.'s long beard, crying, 'Help! Help!' Upon which people coming in and enquiring of the outcry, Coleman made reply that Bobart had eaten his horse and his tayle hung out of his mouth" (Wood's MS., E 32, fol. 23).

1670, Dec. 20. William Henry, Prince of Orange, nephew of the King. "Bobart, the gardiner also received him with a Dutch compliment" (Wood).

1682, May 31. Ambassador from Morocco. "Dr. Morison harangued him."

1683, May. Duke of York, "his dutchess and his daughter the lady Ann." "Dr. Morison the botanick professor speaking an

* "In the published account of the Duke's travels, it is said that the purport of various congratulatory addresses was not sufficiently understood on account of the peculiarity of pronunciation" (Macray). Perhaps Bobart, being a foreigner, was the one man whom he could understand -hence the liking and the reward. 
English speech was often out and made them laugh. This person, though a master in speaking and writing the Latin tongue, yet hath no command of English, as being much spoyled by his Scottish tone" (Wood, loc. cit.).

I683 (circ.). Thomas Baskerville [p. I88].

I695 (circ.). Celia Fiennes [p. I I, note].

, , $\quad$ D. Hermann of Leyden [p. 12].

I 7 Io, Aug. Zacharias Conrad von Uffenbach [P. II].

,, ,, D. Büttner [p. I2].

I7 I4. John Ayliffe [p. I2].

I 736. C. Linné [p. I 8].

I 749. John Pointer [p. 20].

I 782, Oct. I6. John Wesley.

1784. Sadler, the aeronaut [p. 20, note].

1824. Prof. Schultes of Landshut, Bohemia [p. 22].

1847. Tiglath Pileser [p. 26].

Frank Buckland [p. 26].

Sir Charles Lyell [p. 26].

Prince Charles L. Bonaparte [p. 26].

Prof. Milne Edwards [p. 26].

\section{BOOKS AND PRINTS}

Bibliography of the Botanic Garden "Guide"

1837. The article on the Botanic Garden (pp. $1-16$ ) in Ingram's "Memorials of Oxford "supplied the greater part of the Introduction and the illustrations to Dr. Daubeny's Guide.

\section{First Edition:}

I850. Oxford Botanic Garden; or a Popular Guide to the Botanic Garden of Oxford [pp. I-54], with plan at the beginning and one page of "Regulations," dated May I, I850, at the end. Oxford: Printed by I. Shrimpton.

In this edition the Plan of the Garden was printed on blue paper. The Plan of the Experimental Garden on p. 23 was omitted from later editions.

I have not been able to find a complete copy of this, the first edition of the GUIDE, in Oxford, but a presentation copy is in the library of the Linnean Society, bound with the original pale green paper cover. 
185 I. Supplement. New Houses [pp. 55-58], with a wood-cut of the Victoria Lily and Orchid Houses.

For the loan of a copy of the I 850 Gulde with this Supplement inserted before the "Regulations," I am indebted to Dr. Daydon Jackson, Secretary of the Linnean Society.

1853. Address to the Members of the University. Delivered on May 20, I853, at the commencement of Act Term, and on the completion of the arrangements for receiving the Fielding Herbarium in the room set apart for it within the Botanic Garden.

First issue [pp. I-I5] without covers (F. Madan's Coll.). A later issue was in a cover.

With an Appendix containing a list of the countries from whence the plants were obtained, and of the principal collections of the same [pp. I-22].

Sold only At the Botanic Garden. Oxford : printed by Messrs. Parker, Corn-market Street [N.D.].

Issued in a shiny, bright green paper cover, with one leaf bound in at the end: "Notice. The Fielding Herbarium being now arranged," etc.

\section{Second Edition:}

1853. Oxford Botanic Garden; or A popular Guide to the Botanic Garden of Oxford. Second Edition [pp. I-62]. To which is appended An Address to the Members of the University delivered on May 20, I853. . . With an Appendix [pp. I-22].

Sold at The Botanic Garden only. Printed by Messrs. Parker, Oxford.

The Linnean Society copy is accompanied by a note from Dr. Daubeny dated Nov. 4, 1853. It is the only perfect copy I have seen. It is bound in a shiny green cover, and contains the Plan of the Garden on blue paper at the beginning, and a revised and undated leaf of "Regulations" at the end.

The principal changes in this edition include the omission of the Plan of the Experimental Garden, the inclusion of the I 850 Supplement, and the addition of the 1853 Address. 
I856. Supplement to the Botanic Garden Guide [pp. I-I2]. I864. Oxford Botanic Garden; or A popular Guide to the Botanic Garden of Oxford. Second Edition [pp. I-62]. To which is appended An Address [pp. I-22] . . A And also A Supplement containing an account of the Botanical Museum [pp. 23-34], and of the other principal additions made to the collections since the year I853 [pp. 35-50].

Sold at the Botanic Garden only. Price 6d. I864.

This new title is printed on the shiny green paper cover, but the title-page (p. I) remains the same as in the 1853 edition. The Plan facing the title-page is printed on white paper and has been revised.

The I864 Supplement also occurs separately.

1866. For this, the last edition sold in Dr. Daubeny's lifetime, the 1864 edition was used without alteration, except that a printed slip "Corrected to 1866 " was pasted on the title-page, a leaf entitled "N.B. 1866" was inserted at the beginning, and four pages (pp. 5I-54), entitled "Arboretum" and "Names of the Trees and Shrubs in Christ Church Walk, I864," were added at the end.

That Dr. Daubeny intended to publish a new edition of his Guide, is indicated by two interleaved copies of earlier editions in the Botanic Garden Library, containing notes added by him in $\mathbf{1 8 6 7}$, the last year of his life. One is labelled " Botanic Garden Houses."

\section{List of Works relating to the Botanic Garden}

Bridges from the old world to the new.-CaRLYLE.

For the earliest history, consult MSS. Twyne, vi. 161-173, and xxi. 838, among the Oxford Univ. Archives.

I616, July 26. Lease from Magdalen College to Humphrey Ellis for 20 years.

I62I, March 27. Surrender of lease by Ellis to the University for $£ 250$.

"April II. Announcement by Vice-Chancellor of payment of $£ 250$.

", July 25. Opening Ceremony and Foundation.

" , 28. New direct lease from Magdalen College to the University.

" Nov, 6, Contract for bụildings: 
I648. Bobart, Jacob. Hortus Medicus Oxoniensis. Catologus Plantarum Horti Medici Oxoniensis, Latino-anglicus et anglico-latinus [pp. $4+54$ ]. An English Catalogue of the Trees and Plants in the Physicke Garden of the Universitie of Oxford [pp. I-52]. I2mo. Oxon.

1653. Paulli, Simon. Viridaria varia regia et academica. Copenhagen. [Reprints Bobart's Hortus Medicus Oxoniensis.]

1658. Stephens, P., Browne, W. [and Bobarts, father and son]. Catalogus Horti Botanici Oxoniensis [pp. $16+187]$. The Second Part of the Catalogue of the Trees and Plants of the Physick Garden in the University of Oxford [pp. $6+193-214]$. 16 mo. Oxon. [The second edition of Bobart's first Catalogue.]

I662. [Gayton, Edmund.] Upon Mr. Jacob Bobart's Yew-men of the Guards to the Physick Garden, to the tune of the "Counter Scuffle."

,, [Gayton, Edmund.] A Ballad on the Gyants in the Physick Garden in Oxford, who have been breeding feet as long as Garagantua was Teeth.

1664. [Drope, John.] Upon the most Hopefull and ever-flourishing Sprouts of Valour, the indefatigable Centrys of the PhysickGarden.

I 668 (circ.). Wood, A. History and Antiquities of the University of Oxford. MS. in Bodleian, Wood, F 2, fol. 98-9. Gutch's edit. 1786. I669. Morison, R. Praeludia Botanica.

I672. ,, ,, Plantarum Umbelliferarum Distributio nova. Fol. Oxon.

I676. Morison, R. MS. Catalogue of Plants in the Library of the Botanic Garden.

r68o. Morison, R. Plantarum Historiae Universalis Oxoniensis, pars secunda. Fol. Oxon.

1683. Baskerville, Thomas. See p. 188.

1684. Plot, R., and Bobart, J. A discourse concerning the effects of the great Frost, on Trees and other Plants, anno 1683. Drawn from the answers to some Queries sent into divers Countries by Dr. Rob. Plot, S.R.S., and from several Observations made at Oxford by the skilful Botanist, Mr. Jacob Bobart. Philosophical Transactions, xiv. pp. 766-789.

, Cater, William. Horti Botanici querela. Elegiacs recited "indifferently" at the Encaenia, July II, "because the frost last winter kill'd most of the trees."

1699. Morison, R., and Bobart, J. Plantarum Historiae Universalis Oxoniensis, pars tertia. Fol. Oxon. 
I713. [Abel Evans.] Vertumnus. [An anonymous poem addressed to Bobart.]

I728, Oct. 4. Extract from Sherard's Will read in Convocation. Reg. Conv., Bd 3r, fol. 262.

I 732, Feb. 8. Orders relating to the Garden. Reg. Conv., Be 32, fol. 2 I. 1834. Daubeny, C. Copy of a Report presented to the Visitors of the Oxford Botanic Garden at their desire by the Professor of Botany. Oxford, March 14, 1834.

,, Daubeny, C. An Inaugural Lecture on the Study of Botany read in the

Library of the Botanic Garden, Oxford, May I, MDcccxxxiv.

These two publications appear to have been afterwards issued together in a brown-paper cover entitled "Professor Daubeny's Inaugural Lecture on the Study of Botany," with two engraved plans of the Garden-the "Hortus Botanicus Oxonii," showing the existing state, and the "Plan of the Botanic Garden," * showing the suggested improvements to be submitted to the Garden Committee ; and also a "Synopsis of a Natural System of Arrangement of Plants" printed on one leaf, which had probably been circulated among the audience present at the Inaugural Lecture.

1839. Baxter, W. Remarks on Garden Tallies. Gardeners' Magazine, p. 542. Baxter, W. Effect of the Winter of $1837-8$ on the Trees and Shrubs in the Oxford Botanic Garden. [On January 20 of that winter, the thermometer sank to $I^{\circ} \mathrm{Fahr}$.]

1851, Nov. 28. Daubeny, G. C. B. Statement respecting the Money spent upon the Botanic Garden.

I856, Feb. 20. B.D. The Botanical Gardens. A leaflet to protest against the Is. entrance-fee to the green-houses.

,, Feb. 2I. Daubeny, G. C. B. A Paper on the Pecuniary Maintenance of the Botanic Garden.

,, Feb. 2r. The Professor of Botany? Botanical Gardens.

, March I8. Daubeny, C. [Letter] To the Members of Convocation. Answer to B.D., and balance sheet for 1855 .

1864. Robinson, W. Notes on the Oxford Botanic Garden. Gardeners' Chronicle, pp. 722, 747, 77 I.

1870. Lawson, M. A. Oxford Botanists. Gardeners' Chronicle, p I024. 1875, Nov. 25. Anon. The Oxford Botanic Garden. Nature, xiii. p. 61.

, Acland, H. W. A Letter to Dr. Hooker. Second Edition. [The first copies issued were recalled on account of a personal remark, which was expunged from later issues.]

* A revised edition of this plan, "with the projected additions" partly carried out, and showing alterations to beds and shrubberies, was printed circ, 1845. I am indebted to Mr. James Pạrker for a copy. 
1875. Lawson, M. A. [Leaflet.]

I876. , , , Report and Letter published in the University Gazette for May 22.

Acland, H. W. The Botanical Gardens and the Administration of Science Apparatus in Oxford.

1883. Chapman, E. Report on the Botanic Garden for $\mathbf{I} 883$.

, Hooker, J. D., and Dyer, W. T. T. Memorandum on the Oxford Chair of Botany.

1886. Druce, G. C. The Flora of Oxfordshire. 8vo. Oxford and London. I888. Balfour, I. B. [Letter] To the Curators of the Botanic Garden, Oxford.

i889. Curators of the Botanic Garden. First Annual Report. [These Annual Reports have been continued until the present time. They are printed in the University Gazette and in Reports of University Institutions, and are also issued as separate pamphlets.]

I890. Vines, S., and Baker, W. G. Delectus Seminum Horti Botanici Universitatis Oxoniensis.

1893. Curators of the Botanic Garden. Botanic Garden. Application to Convocation for special grant to enable them to rebuild the Garden-Houses.

I900. Baker, W. G. Aquatic Plants. In the I900 Supplement to George Nicholson's Dictionary of Gardening, pp. 70-78.

, Baker, W.G. Aquatic Plants. In the Book of Gardening edited by Drury, pp. 863-926. [With illustrations of the Oxford Waterlily Tank, and of flowers grown in the Oxford Garden.]

1904. Guinther, R. T. A History of the Daubeny Laboratory, Magdalen College, Oxford. 8vo. London.

I9II. Vines, S. H. Syllabus of a Lecture on the Origin of Systematic

Botany: Morison and Ray. Delivered on Feb. 3, I9II, at the University of London. Privately printed. Oxford.

In preparation. Vines, S. H., and Druce, G. C. The Herbarium of Morison and Bobart. Oxford.

\section{PRIN'TS}

I643. Hollar. Map.

I675. Loggan. Hortus Botanicus. The Physick Garden in Oxon. Plan, 16 in. $\times 19 \frac{1}{2}$ in., with inset views of the East Gate, inside and outside views of the Danby Gate, and the Conservatory for Evergreens. The "Giants" are shown in this view. In Daubeny's reduced engraving (p. 7) the beds are reduced in number.

I 707. Beeverel, J. Jardin de Médecine à Oxford. [Plan after Loggan.] Delices, p. 534 . 
I7 19. Oxford Almanack. See p. I3, note.

I733. Williams, W. Hortus Botanicus. Bird's-eye view, I6 $6 \frac{3}{8}$ in. $\times$ I9 $\frac{3}{4}$ in., with insets, reproduced on p. $\mathbf{1 5}$.

1766. Oxford Almanack. [View of Conservatories.] S. Wale del. ; Green sc. This view was re-engraved by J. Skelton in 1820 , vide Oxonia depicta, and again by Storer in 1821 , see below.

I 790 (circ.). [View of Danby Gate, surcharged with a large J.] $1 \frac{7}{8}$ in. square. Bookplate of the Botanic Garden Library. In a later edition, inscribed E. BIBL. BOTAN. OXON., the J was omitted.

1792. Oxford Almanack for 19II. [Coloured view of the East Wall and Magdalen Tower, by Ed. Dayes.]

1797. Oxford Almanack. Magdalen Tower and Bridge. Shows a stone building at the corner of the East Wall. No willow. Top of East Green-house.

I8I4. Pugin, A. Botanic Garden. D. Howell, sculpt. ; published by Ackerman, Dec. I. Coloured engraving, $7 \frac{1}{4}$ in. $\times 5 \frac{1}{8}$ in. A view through the open gate.

1821. Storer, J. and H. S. Botanic Garden, $4 \frac{3}{8}$ in. $\times 2 \frac{5}{8}$ in. [Green-houses from S.W.] In R. Lascelles' University and City of Oxford.

1829. Whittock, N. [View of the Danby Gateway.] Vignette to the lithographed title-page of The Microcosm of Oxford.

I831. Whessell, J. View from the Physic Gardens. Vignette to the titlepage of Oxford Delineated, published by J. Whessell. This view of Magdalen Tower from the Garden shows the Gateway and old Yew Hedge in the foreground.

1836. Mackenzie, F., and Le Keux, J. The Botanic Garden, $5 \frac{3}{8}$ in. $\times 3 \frac{3}{4}$ in. In Ingram's Memorials. View of Gateway, Magdalen Tower, Library, the Professor's New House, and Magdalen Bridge, with Dr. Daubeny's new Aquarium and Fountain in the foreground.

I 845 (circ.). Knight. Gate of the Botanic Gardens at Oxford. $3 \frac{1}{4}$ in. $\times 4 \frac{1}{2}$ in. In Old England.

1885. Water-lily House. Woodcut in Gardeners' Chronicle, p. 84.

, Fountain.

„, General View.

$\begin{array}{lll}, & \text {, } & \text { p. } 540 . \\ & \text {,, } & \text { p. } 732 .\end{array}$

1900 (circ.). Views of Botanic Garden, pp. I 23 and I3I in T. Whittaker's Sights and Scenes in Oxford. N.D.

1901. View of Lily Tank in the Oxford Botanic Garden. In G. Nicholson's Dictionary of Gardening, Supplement, p. 74, fig. 71.

1910(?). Haslehurst, E. Botanic Gardens and Magdalen Tower. A 3-colour print in a booklet called Oxford. N,D. 


\section{APPENDIX A}

\section{THOMAS BASKERVILLE'S ACCOUN'T OF THE PHISICK GARDEN, CIRC. 1683}

From the "Collectanea, IV.," of the Oxford Historical Society, transcribed from "MS. Rawlinson" D.810 in the Bodleian Library

As to $y^{e}$ Phisick Garden \& its Rarityes of that nature, since it stands on ground lately purchased from Magdalen Colledge, it may now justly challenge a remembrance, \& that you may haue a true character of its work \& beauty take here an account of t from him $y^{t}$ now keeps it, the skilfull and Ingenious Gardener himselfe, my friend $\mathrm{M}^{\mathrm{r}}$ Jacob Bobert.

Amongst $y^{\mathrm{e}}$ severall famous structures \& curiosities wherewith $\mathrm{y}^{\mathrm{e}}$ flourishıng University of Oxford is enriched, that of $y^{e}$ Publick Physick Garden deserues not $y^{e}$ last place, being a matter of great use \& ornament, prouving serviceable not only to all Physitians, Apothecaryes, and those who are more imediately concerned in the practise of Physick, but to persons of all qualities seruing to help $y^{\mathrm{e}}$ diseased and for $\mathrm{y}^{\mathrm{e}}$ delight \& pleasure of those of perfect health, containing therein 3000 seuerall sorts of plants for $y^{e}$ honor of our nation and Universitie \& service of $y^{\mathrm{e}}$ Comonwealth. This noble thing was $\mathrm{y}^{\mathrm{e}}$ Benefaction of $\mathrm{y}^{\mathrm{e}}$ Right Honourable Henry, Earle of Danby, who then liued at his house at Corneloury, who, purchasing a most convenient plot of ground of 5 acres of Magdalen Colledge land thereto adjoyning, being aptly watered $w^{\text {th }}$ ye Riuer Charwell by it gliding, and built thereon a most stately wall of hewen stone I 4 foot high with 3 very considerable Gates thereto, one whereof was to the cost of at least 500 pounds, wch worthy work was all finished in $y^{\mathrm{e}}$ yeare 1632. And endowed the same with the Parsonage impropriate of Kirkdale in the County of York, to remain for perpetuitie.

After the walls \& gates of this famous garden were built, old Jacob Bobert father to this present Jacob may be said to be $y^{\mathrm{e}}$ man $y^{t}$ first gave life \& beauty to this famous place, who by his care \& industry replenish'd 
the walls, $w^{\text {th }}$ all manner of good fruits our clime would ripen, \& bedeck the earth $w^{\text {th }}$ great variety of trees plants \& exotick flowers, dayly augmented by the Botanists, who bring them hither from $y^{\mathrm{e}}$ remote Quarters of $y^{\mathrm{e}}$ world, but to proceed.

This Garden Plot is not exactly square, for $y^{\mathrm{e}}$ walkes East \& West are about 120 of my paces or strides wch are more than a yard, But North \& South I trod out but IO6 \& II 2 yards with $y^{\mathrm{e}}$ length of $\mathrm{y}^{\mathrm{e}}$ North-Gate wch is extended $w^{\text {th }}$ out $y^{\mathrm{e}}$ square of $y^{\mathrm{e}}$ wall. Here is a door way lately broke through the middle of $y^{e}$ South wall, but the gates spoken of by $\mathrm{M}^{\mathrm{r}}$ Bobert are in the East West \& Northerne sides, that

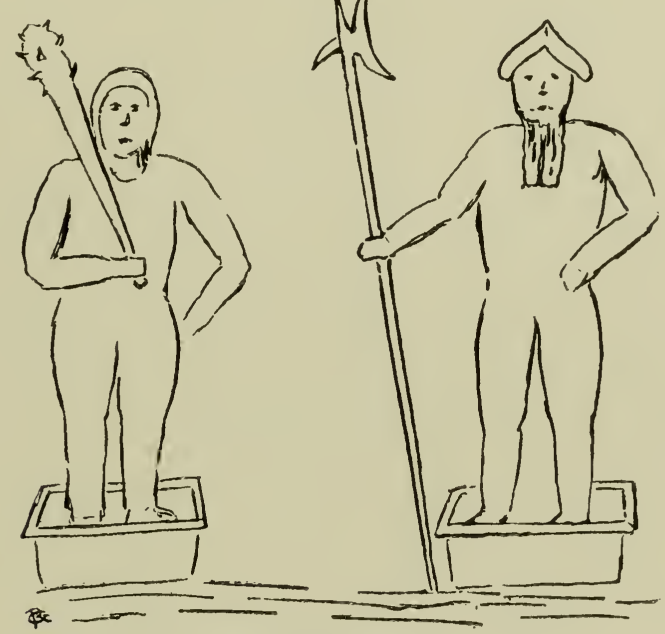

The Sentries

in the North wall wch admits entrance from the City being fairest built, by this Old Jacob some years past got two yew trees wch being formed by his skill are now grown up to be Gigantick bulkey fellows, one holding a Bill th' other a Club on his shoulder which fancy made an Ingenious person strow this Copie of verses on them.

Upon the most hopefull \& ever-flourishing Sprouts of Valour, The Indefatigable Centrys of the Physick-Garden.

Although no brandish'd Cherubins are here, Yet sons of Adam venture not too near, Nor pluck forbidden fruit, if with intent

To visit Paradise be innocent. 
Here's your (nil ultra) else; in each of these Is both a Pillar and an Hercules.

If you do not dread their looks, yet may you fear

The many strange fatalities they bear.

The Embleme of mortality the Yew

Does likewise now $y^{e}$ armed Agent shew;

And if unwearie Mortals slight their guard

They doubly make the Garden a Church-yard.

In this coniunction mischief's never grant,

The Saturnine's become a martial Plant:

ffar off, in heaven it selfe are those bad stars;

What here at hand, when Saturn clubs with Mars ?

Th' Hyperian Dragon, were it not a fable,

Then these our Porters is lefs admirable.

Their blood is poyson; pestilent their breath;

And very shade the shadow is of death.

But since in England they can do no harm

Internall, they for outward mischief Arm;

Desperate poyson in most fforeign ground

Instead of sicknefs here they mean to wound.

(As lately Rebels serv'd that blefsed Head,

When Poyson might not do, they struck him dead).

Who dares be safe? no Turk is armed so,

When every member of them is a Bow.

Even Arms are Armed; Bows charg'd with Mars or Bill,

So that at once with stroake \& shot they kill.

And lop each limb you can not strike them dead;

Each limb will multiply like Hidra's head.

Some vegetables do themselves protest

With prickles, stings, or stinks the game effect.

Our garden Genii, more generall,

Do not defend themselves alone, but all.

Old heroes hung their weapons, so as these,

ffor signal victories on signall Trees:

But, sure of Conquest, these presumptuous Sophyes

Do antidate : are Victors both and Trophyes.

If quibbling Cambridge, when they next Commense,

"Shall say, here's Terræ filii without sense,

"And uery Block-heads" : know that these were meant

ffor Military not a learn'd intent.

Valour and wit at equall Honour fly,

Yet valour often, seldome wit dwels high.

As wisemen are Cowards; so 'tis fit

That combatants haue neither fear nor wit.

Their Education tho they may not brand

Bred in the Gardens Garden of the Land.

Manners makes men, of men, means Wickham's Box

Our Yews declare they may be made of Stocks,

By culture too: And Trunks afsume of late

The grand proprieties of Human state:

Couch'd in an Oake the Soveraignty ye knew

Soe here appropriate valour in the Yew; 
Say, they are speechleis too: the men of Words

They murmur though, \& shake their crests disturb'd By fancy winds : nor would their rage be curb'd, Were't not in vain their Honor to repair, When 'tis to fight the winds, and beat the Ayr': Jove whispers peace; or else we well might wonder He go secure, lets rust his Dasdard Thunder.

These Earth-born Giants take a distant course By plots more perilous than was their force.

Each man's an Ambuscado; and may well Be said at once Perdue and Centinel.

How they advance tow' rds Heaven night and day

And strenghth increeses still upon the way,

Yet moves unseen : But Joves all-kenning eye

Did from these wily stratagems espie

Else might th' All-conquerour haue been surpris'd

As was our own by men in Boughs disguis'd.

So that Apollo sent a league to treat

And to Caress them with a gentle heat;

With numerous presents of his golden Rayes;

With farther promise of serener Dayes.

Else would their force crack Heavens Chariot wheels, But prostrate Earth too hangs about their heels;

And as an Ancient loyall Sabine Wife

Ventures to intercede, and part the strife,

So men, whose humbler scope is heavens Crown,

With darling Earth are clog'd and fetter'd down.

Could we believe but what old people do

They were not only men but Christians too,

Who fright the Div'l himself; had God but set

In his first Colony this Amulet;

No work for Cherub had there been : no doubt

The ffiend had been, and not poor man cast out, And Proserpine might here haue fil'd her lap

With only flowers and not an after-clap:

frrom sons of Adam now we must retrieve

Our warning to the daughters next of Eve.

Gardens of Beauties, many in pursuit

Are of your own choice flow'rs, \& rarest fruit:

Weak is your Sex; you know the Div'l in swine Was nere repuls'd by hedge of Eglantine.

If yet the Courtier ffox, or Ruffian Bore

That Mound haue never undermin'd and tore,

Thus fortifie $\mathrm{y}^{\text {or }}$ selves; in your defence

Set Giant Honour, Giant Conscience.

So shall you never keep, by this advice,

Knaves Kitchen Gardens but ffools Paradise.

So farewell Heroes; who shall sing of you, When as Heroick is Georgick too? 
20 Here I may take leave to speake a word or two of old Jacob who now is fled from his Earthly Paradise. As to Country he was by birth a German born in Brunswick that great Rum-Brewhouse of Europe : In his younger dayes as I remember I haue heard him say he was sometime a Soldier by which Inploy and travail he had opportunitie of Augmenting his knowledge, for to his native Dutch he added the English Language, and he did understand Latine pretty well. As to fabrick of body he was by nature very well built, (his son in respect of him but a shrimp) tall straite and strong with square shoulders and a head well set upon them. In his latter dayes he delighted to weare a long Beard and once against Whitsontide had a fancy to tagg it with silver, which drew much Company in the Phisick-Garden. But to save you further trouble view his shadow in this Picture. [Loggan's engraving of him is here omitted.]

Here I may not omit the Remembrance of a worthy person defunct (though not of my acquaintance) \& that is $\mathrm{D}^{\mathrm{r}}$ Morison a Scotchman who was Botanick Lecturer in Oxford till unhappily brought to his end by a

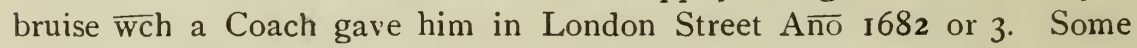
who haue heard him say he was uery ingenious \& pleasant in his discourse on that subject, But whether there be now any Botanick Lecturer in Oxford I can not tell, but $\mathrm{M}^{\mathrm{r}}$ Sherwood of $\mathrm{S}^{\mathrm{t}}$ John's an acquaintance of mine a Lincoln-shier gent and a kin to a Lord of that name there, is a great louer of simpling who wth $\mathrm{M}^{\mathrm{r}}$ Bobert show'd me an Herball set out by $\mathrm{D}^{\mathrm{r}}$ Morrison wch had the best cuts of Plants that I yet haue seen.

Anno 1670. Here was built by the Income of the money giuen by the ffounder a fair Green-house or Conservatory to preserve tender plants \& trees from the Injury of hard winter. 


\section{APPENDIX B̈}

LIST OF Io6 PLANTS TAKEN FROM THE OXFORD COLLECTION BY PROFESSOR LAWSON AND SENT TO KEW IN I882

AGAVE
applanata (2)
atrovirens picta
besseriana
corderoyi
filifera (2)
glaucescens
horrida
lactovirens marginata
lophanta
$\quad$, univittata
roezliana
saundersiana
seemanni
sobolifera
taylorii
verschaffeltii

virginica

peacockiana

vivipara

xylacantha

xylonacantha

Alow

\section{albo-cincta \\ bowiei (2) \\ plicatilis (3)}

serrulata

, sp. Cooper

umbellata variegata

sp. not named (2)
A PICRA

coarctata (2)

fasciata

hybrida

imbricata

reinwardtii (2)

rigida (2)

scabra

spiralis

spirella

tortuosa

sp. not named (2)

"Cereus" (? Sedum)

ebracteata

Diostemon

hookeri

Gasteria

bicolor

coarctata (2)

maculata (2)

marmorata

obliqua

HAwORTHIA

aspera

atrovirens (2)

clariperla (3)
Haworthia (cont.)

cuspidata

, gradata (2)

cymbaefolia (2)

cymbaeformis (2)

granata (2)

laetevirens

margarifera

mucronata (2)

papillosa

parva (3)

planifolia (2)

radula (2)

retusa

, near (3)

scabra (2)

semi-glabrata (3)

semi-margaritifera

subulata

tessellata

turgida (3)

viscosa

sp. not named (2)

Mesembryanthemum

anatomicum

molle

\section{PACHYPHYTUM}

roseum 


\section{APPENDIX C}

\section{THE LEAFLET WHICH SAVED THE GARDEN}

That the Garden is still on its original site is partly, if not entirely, due to the circulation of the following skit.

Dr. Henry Acland's letter dated November 3, 1875, and seriously advocating the removal of the Garden to the neighbourhood of the Museum in the University Parks, was published on November 30,1875 . In the following month the "skit," signed "Nemo," was circulated, which defeated the plan.

A friend writes: "I remember dining at Dr. Rolleston's, and he said, "The abominable scheme is done with: whoever wrote the "skit" has crushed it. Once pour ridicule upon a plan, and it is no use bringing it forward.' And it was dropped."

\section{To the President of the University Removal Co. (Limited) \\ OXFORD, \\ My DEAR Sir, Dec., 1875 .}

The close of the year will probably bring before the University your opinion, which I have not heard officially contradicted, that the Oxford rainfall is excessive, that the planetary theory is not efficient, and that a cataclysm is impending.

As this opinion seems to me to give an incomplete account of the reasons for the great movement set on foot for completing our institutions in the Parks by moving thereto the Radcliffe Infirmary, I venture to hope you will peruse the following statement, and, if need be, reconsider your conclusion on the planetary theory, if it be such as I hear. 


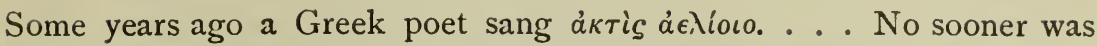
this reported to Oxford by the Daily Telegraph, than sounds of $\beta \rho \epsilon \kappa \epsilon \kappa \epsilon \kappa \epsilon ́ \xi$ коа́ $\xi о \alpha ́ \xi$ resounded from Port Meadow to the Water-walks of Magdalen. A small but earnest band of men assembled, and after long and anxious deliberation determined "that virtue is commendable." From such small germs sprang the great scheme which I now press upon you.

The Radcliffe Infirmary must be removed. It seems impossible, now the Bodleian Library and Botanical Gardens have found a home in the Parks, that the Radcliffe Infirmary should any longer remain in isolation, far off in the swamps of Jericho, and separated moreover from the Library of the same name. One great building only is missing, and that is the Radcliffe Infirmary. The Clinical Professor with his Laboratory and Lecture Rooms are there, but the beds and their inmates remain aloof. Such a separation cannot but be injurious to both.

Once place the Infirmary in the Parks in its true connection with the Museum, and the advantages which would accrue to Science and the public are countless. Let me enumerate a small portion of them. By connecting the Infirmary with the New Observatory, the phenomena of lunacy may be studied in relation with the librations of our Satellite. Its connection with the Physical Laboratory will enable the Professor to investigate the Statics of overtime patients, the temperature of meetings, the gravity of suggestions, and the moments of inertia of Governors generally. The Pathologist may study Elephantiasis Græcorum either from its classical side, or with the aid of Elephas lately placed in the court. Some patients would offer a field of research to the Professor of Entomology ; nor need the Professor of Anthropotomy lack objects of interest. Again, to prevent the dissemination of narrow and false views of nature and treatment by patients on their discharge, a portion of the adjacent Bodleian Library would be fitted up as a Convalescent Ward, and patients copiously supplied with MSS. suitable to their age and nationality.

The Quarterly Courts of the Infirmary would form as constant a nucleus for intercourse among students as they would furnish matter for study to several Professors; for example, the discussions there held would furnish ample material for the Professors of Logic, of Moral Philosophy, and of Metaphysics, while the finances would occupy the attention of the Professor of Political Economy; for which reason, if for no other, it becomes imperative that these Professors with their chairs should be removed to the Museum, as in no other way can their subjects as a whole be studied. It may be objected to my scheme that $I$ have not consulted the Professors concerned. This I consider of no moment; their objections, if any, are temporary, and will speedily be relinquished.

The æsthetic and historical reasons alleged against the removal seem to 
me equally questionable. If the Radcliffe Infirmary be removed, the railings, the fountain, nay the Porter's Lodge, will be there. The buildings and offices only would be gone, the site-its associations and historywould remain. Moreover, the site does not belong to the University, but to the Radcliffe Infirmary. Remove it then, and the chimney of the University Press will still remain a beautiful spectacle, and the site an open vista for all Oxford.

I had almost forgotten to remind you that the Infirmary is unsatisfactory on several accounts. Its buildings are too small, and fresh wards are needed. Rebuild it on its present site, and you needlessly separate the House from the Museum, the Professor from his patients; rebuild it in the Parks, and we have a homogeneous whole, for which the Oxford of the future will bless you.

I should have been disposed to appeal to your generosity as an old friend, not to oppose the promoters of such a scheme, unless you did not approve of it. But I cannot learn that you have really considered it. When I tell you that misfortune planted the Incurable Hospital in Cowley and that a small band of us have laboured humbly ever since to drag it from its obscurity, let me beg and entreat of you to consider and reconsider all this, and help us to complete our work by adding the Incurable Hospital also to those glorious structures in the Parks, in admiration of which the Cherwell itself will linger as it passes. I must add, that should it be found that in years to come the population went further north, or the Science of the future developed a need which could be more worthily satisfied by the presence of other institutions, both Infirmary and Incurable Hospital could easily be removed to their former sites, provided they were kept vacant; but with the example of the Angel site before us there can be no difficulty on that point.

I am,

Yours very truly,

NEMO.

"Nemo" was Mr. Edward Chapman of Magdalen College. 


\section{APPENDIX D}

\section{FOREST GARDENS}

Non omnes arbusta juvant, humilesque myricae;

Si canimus sylvas, sylvae sint consule dignae.-VIrGiL, Georgics.

The Oxford country used to be very well wooded. In the earliest days the Forest of Bagley stretched down almost to the river on the north and enveloped Abingdon on the south. When sea-coal was scarce, the woods were put to the hard task of finding "fuel for all the houses in, and many out of, the shire." The woods of Shotover were held in such . high esteem in the University, that when Charles I. gave them to a person of note who was likely to cut them down, letters on behalf of their preservation were written, one urging "that Oxford was one of the eyes of the land, and Shotover woods the hair of the eyelids, the loss whereof must needs prejudice the sight with too much moisture flowing therein "(Fuller). One of the disasters of the Great Rebellion was the cutting down of the woods.

Parts, however, of the old forests survived, and extensive areas have been afforested. According to the returns published in the "Victoria County History," in I905, there were :

Coppice .

Plantations (under Io years old) . I, 385 ,"

Other woods . . . . . 18,528 ",

Total woodland . . $\overline{\underline{24,377}}$ "

So that the woodlands of Oxfordshire and Berkshire are still 
sufficiently important to determine that a School of Forestry should come to Oxford rather than go to any other University.

Shortly before Michaelmas Term, 1905, negotiations were concluded between the Secretary of State for India and the University for the transference of the School of Indian Forestry at Cooper's Hill to Oxford, under the superintendence of Sir William Schlich.

In November the Royal English Arboricultural Society presented to Magdalen College a large number of young Conifers, which were planted in a Pinetum in Tubney Wood.

In the winter of $1905^{-6}$ a Nursery was laid out in Bagley Wood, with the leave of St. John's College.

The following account of the Bagley Forest Garden is given by Sir William Schlich : "Over I00,000 plants of various species, brought from Cooper's Hill, were planted in it, and seed of a considerable number of species sown. In the following year a commencement was made with the establishment of sample plots of the more important timber trees, and up to date 14 acres have thus been planted in groups (each generally one quarter of an acre in extent) of the following species :

"In 1907 :

Cedrus deodara

Picea excelsa

,, sitchensis

Pinus laricio, var. Corsicana

,, strobus

Pseudotsuga douglasii

Abies pectinata glauca

Larix sibirica

Quercus pedunculata

, sessiliflora
Deodar

Norway Spruce

Sitka Spruce

Corsican Pine

Weymouth Pine

Vancouver or Oregon Douglas

Fir

Silver Fir

Siberian Larch

Pedunculate Oak

Sessile Oak

"In addition a plot of naturally regenerated Oak was established. 
"In 1908 :

Pedunculate Oak, pitted

, , notched

Sessile Oak, pitted

, , notched

Quercus rubra, American Red

Oak

Fraxinus excelsior, English

Ash
Fraxinus americana, American Ash

Acer pseudo-platanus, Sycamore

Acer planoides, Norway Maple Castanea vesca, Edible Chestnut

Ulmus campestris, English Elm ,, montana, Wych Elm

"'The spaces under the remaining old Oak-trees were filled up with plants of Beech and Cypress.

"In 1909:

Thuja plicata

Tsuga albertiana

Larix leptolepis

, europaea

Sycamore and Norway Maple
American Red Cedar

Western Hemlock

japanese Larch

Common or Tyrolese Larch

"Also a series of mixtures of some 20 species were laid out to give to the students an opportunity of watching the comparative height growth of the species.

"During the present year further extensions are contemplated.

"Previous to the advent of the School of Forestry, the Rev. H. J. Bidder of St. John's College had started the planting of a considerable number of Conifer species, and these have been very considerably extended during the last few years.

"Experience has so far shown that-

"I. The Siberian Larch is not suited to this climate, as it generally begins to sprout in January, if a few mild days occur, and is subsequently crippled by frost.

" 2. Sitka Spruce is very liable to be attacked by the Honey fungus, Armillaria mellea. 
"3. Ash does not thrive well, for reasons which are now under investigation.

"4. Experiments with artificial manure in the Nursery did not lead to any results, except that they produced in the following year a vigorous growth of grass.

"5. Douglas Fir, especially the quick-growing Oregon variety, is easily thrown by wind when young, unless most thoroughly protected, while Sitka Spruce has so far not been injured.

"A well-appointed building * was erected [in Oxford], partly in I906-7 and partly in I908-9, by the generosity of St. John's College, one wing being occupied by School of Rural Economy, and the other by the School of Forestry."

* For the poem "Struthio. Lament of the Forestry Ostrich," on the sculptured crest which is perched on the outside of the building, see the Oxford Magazine for Nov. 26, 1908. 


\section{APPENDIX E \\ NOTES ON THE GARDENS OF THE COLLEGES}

The Colleges, whose grassy plots

Are now resorts of vicious ease,

Were then laid out in little lots,

With useful beans and early peas:

Each merely ornamental sod

They dug with spades and hoed with hoes:

The wilderness in every quad

Was made to blossom as the rose.-Godley.

Though amply sufficient for the purposes for which it was originally founded, the Oxford Botanic Garden is not spacious enough for the many uses to which it is at present being put. The size of many plants forbids their being grown to their full proportions within Lord Danby's walls, while a great many desirable species, trees more especially, must for ever be excluded : it is not able to supply all the smaller plants required for class demonstration or for research, still less to serve as a satisfactory arboretum.

In this respect Colleges with gardens might give great assistance if the divided labours could be properly organised; not that we would be thought to suggest the gardens being governed or planted out by one central authority-the failure of so many of the trees in the University Park has been a lesson in that respect-but, what would seem quite feasible, that lists be made from time to time of plants of which it is desirable to have specimens in Oxford, but which cannot be seen here now. Many an intending planter would be glad to have such a list to consult. 
The Botanic Garden might also, unless hampered by a gelosia di mestiere, make annual distributions of plants among College gardens, and thus endeavour to raise the quality of the plants grown in the latter.

The University Gazette annually publishes long lists extending from Argotti to Zagrabia, and from Sheffield to Shipbur, of institutions and of people who contribute to, and therefore presumably also receive plants from, the Botanic Garden. But from these lists the names of Oxford Colleges are invariably absent, and there is no reason that this should be so. Many Colleges would willingly supplement the exhibits at the Botanic Garden by plants of their own growing, and thus render services to horticulture or to arboriculture, meanwhile enhancing the beauty and interest of their own grounds. College Bursars and Garden Masters, although there have been and are splendid exceptions, have not on the whole proved themselves skilled in the care of trees, and in consequence we have few really large specimens of trees in Oxford; but where they do occur, none can deny that there is no fitter association than that of venerable buildings and noble trees, both endued with the dignity of age and the memories of the past.

But a College garden must always keep its individuality; its beauty must be the outward sign of the fostering care of those to whom, for the time, it belongs; it must show, as Goethe has expressed it, "Dass nicht ein wissenschaftlicher Gärtner, sondern ein fühlendes Herz den Plan gezeichnet."

The idea of co-operation is not new. It was put into practical execution fifty years ago, when W. H. Baxter planted several trees in Christ Church Walk, in situations indicated in detail in the 1866 edition of Dr. Daubeny's Guide; but most have perished, and the survivors bear the marks of having passed through a prolonged period of neglect, a period which, judging from the abundant signs of antiseptic treatment of scars and wounds of the trees, has passed away. 
In the following notes on College Gardens the measurements are of trunk-girths taken at a height of $4 \mathrm{ft}$. above the ground. Trees which are the largest of their kind in Oxford, known to the compiler, are indicated by the use of clarendon type.

Christ Church. The names of the principal trees in the Walk round Christ Church Meadows are given in order, starting from the Rose Lane entrance and proceeding round by the Barges to the gate in Fish Street (St. Aldate's).

Rose Lane Gate to Deep Martin.

The young Limes in the Avenue have attained to a girth of about $3 \mathrm{ft} .6 \mathrm{in}$. The large Poplar, P. alba, in the meadow has a girth of $16 \mathrm{ft}$. 3 in. ; but its still larger companion, which was blown down across the Cherwell last winter, measured over $6 \mathrm{ft}$. in diameter.

Just north of the Broad Walk are: Elm, I4 ft. Io in.; Beech, 8 ft. 3 in.; Ash, 9 ft. 5 in. The last large Elm at the end of the Broad Walk* girths $13 \mathrm{ft} .3$ in. In the clump to the south is Fraxinus monophylla ( $=$ heterophylla), mentioned by Walker in 1833 , by Daubeny in 1864 , and recently measured by Mr. Druce as $65 \mathrm{ft}$. in height and $4 \mathrm{ft} .7$ in. in girth (Elwes).

Just beyond the plantation and beside a sluice is an aged Negundo fraxinifolia, $5 \mathrm{ft} .3 \mathrm{in}$., in a dying conditionobviously the result of neglect, having become overgrown by large Willows. A little further on are a small-leaved Maple, Acer monspessulanum, $5 \mathrm{ft} .6$ in., and a Pyrus intermedia, of $5 \mathrm{ft} .3$ in. Populus candicans, P. dilatata, and (?) canadensis used to grow here. By the ferry is a Zelkova of $8 \mathrm{ft} .9 \mathrm{in}$.

Between Deep Martin and the Island many fine Alders will be noticed on both sides of the Cherwell; one, with four limbs

* Near this end of the Walk, Daubeny, in 1864, noted Fraximus heterophylla and Alnus glutinosa laciniata; also quite young trees of Ailanthus, Acer pseudo-platanus, fol. purp., Aesculus carneum, and the Glastonbury Thorn of Baxter's planting. 
rising from a single bole, measures $6 \mathrm{ft}$. across at the ground. The Rhododendrons planted by Baxter have perished long since; but a Norway Maple, Acer platanoides, 5 ft. 3 in., is probably the one known to him as a young tree. I am not certain whether Crataegus coccinea is still there or not.

Near the hut of the O.U.H.S.-man are a Weeping Elm, Ulmus montana pendula, $6 \mathrm{ft}$. I in., and a large Plane, I I ft., and further on, an Alder of $7 \mathrm{ft}$.

Between the Island and the Dean's Ham we noted a Birch, $6 \mathrm{ft} .3$ in., an Ash, $6 \mathrm{ft}$, and a magnificent Zelkova, Planera richardi,* measuring $\mathrm{I} 2 \mathrm{ft} .8$ in. round the deeply furrowed trunk - the most noteworthy tree in the Meadows, and growing quite as vigorously as those we have seen, $60 \mathrm{ft}$. in height, in their native Georgia, south of the Caucasus. Further on are several fine Planes, both Platanus occidentalis, Io ft. Io in. to $7 \mathrm{ft}$. $8 \mathrm{in}$., and two P. orientalis, by the water's edge, of I I ft. $8 \mathrm{in}$.; and by the bridge which leads over the Cherwell to the Barges is a Birch, $4 \mathrm{ft} .7$ in. in girth.

A Poplar Willow, Salix fragilis var. decipiens, Hoff., was estimated by Baxter in 1830 to be fifty years old, $50 \mathrm{ft}$. high, and near the ground $6 \mathrm{ft}$. Io in. in girth (Druce's "Flora of Oxford").

In the plot of ground known as the Dean's Ham between the bridge and the outlet of the Trill Mill Stream, W. H. Baxter, in I862-3, planted Crataegus donglasii, Pyrus pinnatifida, present girth 4 ft. 4 in., Acer saccharinum, Weigela rosea, and several Conifers :

Sequoia gigantea (3),

Pinus excelsa (3),

Cupressus lawsoniana,

Pinus laricio,

Thuja gigantea,

," lobbiana,

Picea nordmanniana,

Pinus cembra ;

but only one Sequoia gigantea, $5 \mathrm{ft}$., a Pinus, $3 \mathrm{ft}$. 9 in., $P$. excelsa, I ft. 7 in., and Thuja gigantea, $2 \mathrm{ft} .3$ in., are

* Mr. Elwes, for the purposes of his big book on Trees now in course of publication, has transplanted (in a literary sense) this tree to the University Parks. 
there now. A dead Sequoia has a girth of $3 \mathrm{ft} .3$ in. Near it stands an interesting Thorn, Crataegus sp. with large leaves, which is in danger of being replaced by the abundant growth from below the graft. It needs pruning.

At the east end of the Ham is a Weeping Elm, 2 ft. 9 in., and in the middle are three Poplars of close on $\mathrm{Io} \mathrm{ft}$. girth, and a Cut-leaved Alder, $4 \mathrm{ft} .2 \mathrm{in}$. The Ulmus glabra we have not identified. Many of the trees in the meadow are not enclosed and have been badly barked by horses. Near the fence are a Hornbeam, $5 \mathrm{ft}$. ro in., and a Willow, $9 \mathrm{ft}$. ro in.

Near the outlet of the Trill Mill Stream (= Pactolus, for reasons explained in Buckland's "Curiosities of Natural History") are several Alders (one measuring $6 \mathrm{ft} .8$ in.) and Oaks (one, a fine Turkey 0ak, Quercus cerris, measuring $8 \mathrm{ft} .7$ in.). Daubeny also recorded Fraxinus lentiscifolia near by.

The Almond which Baxter planted at the end of the Broad Walk has not survived; but near by are a recently planted Plane and an Ailanthus.

The Elms of the Broad Walk were planted after the Restoration, and, in 1683 , they were noted by Baskerville to be "pretty well grown," but now, having reached the limit of their life, are falling like ninepins before south-westerly gales.*

* The sequela have been quoted to me by Mr. J. J. Lister, as follows :

AFTER A STORM

To-day God bloweth with His wind;

He wrestles with the elm trees tall,

And with a roar and with a crash

The Giants fall.

To-morrow Mr. Focus comes,

He has been early to the scene,

And photographs the prostrate trunks

With his-machine!

And now, not many days elapsed,

I pass his window in the town,

Lo! "Souvenirs of Friday's Storm"

At half-a-crown.

There are points of resemblance between our two ancient Universities ! 
The Walk was made in I $7 \mathrm{I} 7$, and was at first known as the White Walk, on account of the colour of the stone rubbish used to raise it. Hence "Wide Walk," whence "Broad Walk."

The largest of the two ivy-covered stumps at the end of the New Walk measures about $4 \mathrm{ft} .8$ in. through. Gaps in the Avenue are being filled with the quick-growing Huntingdon Elms, U. montana vegeta, but it is not certain that they will prove as satisfactory in the long run as the ordinary variety.

The Christ Church Gardens.* The doyen of all the trees is the Plane in the Garden of the Lady Margaret Professor of Divinity at Christ Church, which is supposed to have been planted by Dr. Pococke when Professor of Arabic in 1636 . It is truly a magnificent tree. Its girth, I $8 \mathrm{ft}$. Io in. in 1887 (Gardeners' Chronicle), seems to have increased to I9 ft. 3 in. in I9II. The trunk soon divides into two enormous limbs, with girths of $\mathrm{I} 3 \mathrm{ft} .9$ in. and $10 \mathrm{ft} .2$ in. respectively; the branches cover an area of about 30 yds. in diameter. The trunk-girths of other trees in the garden are: Walnut, $5 \mathrm{ft} .4$ in.; Mulberry, $3 \mathrm{ft} .5$ in; Box, $2 \mathrm{ft} .2$ in. The nearest Yew, in the corner of the Cathedral burying-ground, has a girth of $6 \mathrm{ft}$. I I in., which is of course small as compared with the old yew in Iffley Churchyard.

In Canon Driver's Garden the most noteworthy tree is a wreck of a fine Catalpa, girth $7 \mathrm{ft}$., with a spread of branches of 13 yds. Only one branch is now living. Among the other trees, a wall Pear measures I ft. 6 in. across the longer diameter of its oval stem; a Double Cherry has a trunk-girth of $3 \mathrm{ft} .3$ in., and a straight-stemmed Robinia, a diameter of I ft. 6 in. More famous than all is the large Fig-tree, the numerous suckers of which have covered a length of wall of $25 \mathrm{yds}$. The tree is of exceptional interest, because it was almost certainly brought from the East by Edward Pococke, * I am greatly indebted to the owners of these gardens for permission to measure their trees. 
who had been chaplain to the Levant Company at Aleppo in I630-6, when he became our Professor of Arabic. The condition of the tree in 1806 is shown in a print by J. Storer, with the title-

Arbor Pocockiana, imagine accuratissimâ aere expressa.

Ficus Arbor, ex Syria olim regione a Celeberrimo Edvardo Pocockio, circiter centum et septuaginta abhinc annis, prima quidem sui generis, in Britanniam advecta, hodieque in horto Professoris Ling. Heb. apud Oxonienses, virens et fructuosa. Junii I $2^{m o}$, A.D. 1806 .

Altitudo Arboris 21 pedes; ambitus trunci

in parte superiori, 3 pedes 6 unciae.

In the Deanery Garden grew the large Jamaica Walnut described by Pointer as a tall tree in I749. The Common Room table was made from it. About a hundred years ago it was replaced by a Horse-chestnut which has grown to be a perfect specimen tree, with a trunk-girth of $12 \mathrm{ft}$. 6 in. and a spread of branches of about $\mathrm{I} 7 \mathrm{yds}$. in diameter. The Virginian Creeper against the Library, when in autumn it glows red over the ivy, is one of the most beautiful coloureffects in Oxford.

In the Archdeacon's Garden may be seen the holes which Buckland built to test the truth of the stories of the longevity of frogs imprisoned in cavities of rocks.

Pembroke College. The Mulberry in the corner of the Fellows' Garden has a trunk-girth of $4 \mathrm{ft}$. Io in. It may conceivably be the same tree as the one described by Loudon in 1838 as being $25 \mathrm{ft}$. high, with a trunk-girth of $2 \mathrm{ft}$. 2 in. One of the two original Mulberries, called Shenstone's, planted before 1624 , lived until 1833 . Two tables in the Common Room were made of its wood, and also a carved snuff-box as a "Memento mori." The Limes were planted in 1864 .

Merton Garden used to be much admired for the natural growth of the trees as compared with the stiff and formal 
vegetable statues of other gardens. An early appreciation is that of Bishop John Earle in his "Hortus Mertonensis" of 1624 .

Von Uffenbach, in $17 \mathrm{IO}$, wrote that it was considered the finest in Oxford, although it consisted of " a grove or some low dark walks which, as they have no proper air, are not pleasant. At the side is a raised path and a poor pleasure house." The latter was built in 1706 , the year before the terrace-walk was made on the old Town Wall.*

At the present day it is an ideal garden of light and shade and of beautiful views. The oldest living tree is undoubtedly the "starling-beloved "Mulberry, which is believed to date from the time of James I. $\uparrow$ The trunk measures $7 \mathrm{ft}$. 8 in. at a height of $2 \frac{1}{2} \mathrm{ft}$. from the ground, and is therefore not much smaller than the old tree at Balliol. The Merton tree is the finer of the two.

It is not improbable that some of the Mulberries of this date were grown from the packets of seed distributed by Royal Edict of James I., I605, for the encouragement of the silk industry in England. Unfortunately the seed circulated was that of $M$. nigra, less suitable for silkworms than $M$. alba.

It is essentially a garden of Limes, Yews, and Sycamores. The finest Sycamore, girthing Io ft., forms the subject of an illustration to Mr. Henderson's book on the College. Another girths $8 \mathrm{ft} .4 \mathrm{in}$., and the best of a clump of five, $7 \mathrm{ft} .4 \mathrm{in}$.; but we do not believe that any of these is as old as r680, a date at which there were stated to have been Sycamores in the garden.

The Lime Avenue was in existence in 1760 , when there were eight trees on the south side and seven on the north. These were reduced to six a side. The largest, at the western end, girths $9 \mathrm{ft} .6$ in., and another $8 \mathrm{ft} .6 \mathrm{in}$.

Of the trees planted in 1744 along the north wall none * Boase's "Oxford."

† The dates are taken from Henderson's " History" of the College. 
survive, unless the old Horse-chestnut be of that date. Among the other trees, two Horse-chestnuts measure i $2 \mathrm{ft}$. and I I ft. 6 in. respectively; an Evergreen Oak, 5 ft. 4 in.; Pinus excelsa, $3 \mathrm{ft} .7$ in.; Cypress, $3 \mathrm{ft}$. 6 in.; the largest Yew in the north-east corner, $4 \mathrm{ft} .2$ in., but a larger bole, lying near, measured $2 \mathrm{ft} .3$ in. in diameter.

University College. The original Fellows' Garden was on the site of part of the Master's Garden until about r8o9, when Deep Hall was pulled down, and the present Fellows' Garden was laid out on the site.

In the sheltered garden overshadowing the Shelley Memorial grows a Tulip Tree, second only in point of size to the tree in the garden of the Warden of Wadham. The trunk, $9 \mathrm{ft}$. 2 in. at the level of the grass, divides into two limbs; the larger of which girths $6 \mathrm{ft} .2$ in. and supports the greater part of the tree, and is a conspicuous object as seen from the High Street, especially in October, when the leaves form a bright yellow background to the dome of the Memorial.

A Mulberry near has a girth of $5 \mathrm{ft}$.; a Robinia near the Chapel measures a trifle under $6 \mathrm{ft}$., and in the Master's Garden are a large Hickory, 7 ft. 9 in., a Mulberry, 7 ft. 6 in., and a fine Pear, $5 \mathrm{ft}$. ro in.

A grove of Walnut-trees is believed to have stood on the site of the Tutor's House in Grove Place. It was cut down at the beginning of the eighteenth century.

Queen's College. A White Fig-tree is said to have been grown from a seed of the celebrated botanist and traveller, Dr. Shaw, who collected plants in Barbary and the Levant, circ. 1720 (G. C. D.).

Magdalen College.

There were elmes great and strong.-ChAUCER.

Magdalen will be remembered for an Oak, an Elm, and an Ivy. The two former died of ripe old age, the monarchs of their race; the latter, we regret to say, was felled in 
the prime of life, on the false assumption that it was harming the masonry of the Great Tower. The roots of the Ivy penetrated the vault of an adjoining wine-cellar, and, after branching about in the sawdust in which the bottles lay, made for a cork through which some moisture was oozing, entered the bottle, drank up all the port, and then filled the bottle entirely with a matted tangle of roots all growing in search of more of the ambrosial liquor, but unable to get through the glass!

The Roman poet understood ivy better than we do, when he wrote :

$\mathrm{Tu}$ tamen e sacris hederae cultoribus unum

Numine debueras sustinuisse tuo.-Ovid, "Tristia," V. iii. I5.*

Cur hedera cincta est ? hedera est gratissima Baccho.

Ovid, "Fasti," iii. 767.

Repeated attempts were made to cut the Ivy down. In I 892 the then Bursar proposed it, but was outvoted. In February, 1904, the House Bursar again asked the leave of the College to cut it, but the Ivy was saved by 9 votes to 7 . At last, in November, 1908, the Waynflete Professors of Physiology and Botany persuaded the College to have it removed, and won their case by I 5 votes to II.

The Ivy was stripped from the Great Tower on what I have always held to be a false accusation. The true one has been stated. Ivy does no harm to a building so long as the walls remain $d r y$. It is when a feeling of moisture encourages the plant to believe that there is more drink behind, that damage is done to masonry.

Ivy roots do not penetrate into well-built, dry walls. The foliage, on the other hand, affords efficient protection against the wet of a driving rain, and, more important still, against

* For this reference I am indebted to Mr. Godley, who understands the greater Classical poets even better than they understood the ivy. 
the sulphuric acid-laden raindrops, ${ }^{*}$ the product. of town life and town industries, which are such an important factor in the corrosion and disintegration of our Oxford calcareous building-stone. Anything that will keep wet and frost from such walls will lengthen their life. But when ivy is forcibly stripped from a wall, however carefully done, the surface of the stone gets stripped too, and masonry joints get opened, as many places in the walls of Magdalen show. Such a wall denuded of its natural covering, and with large portions of its surface stripped, is then far more vulnerable to the attacks of atmospheric and chemical agencies, and will soon require restoration.

A remarkable instance of the lengths to which ivy roots will go in the ground in their search for water was brought to the notice of the present Bursar a few years ago. When some excavations were being made in the floor of the College Chapel for the purpose of laying hot-water pipes, the workmen found ivy roots under the pavement reaching as far as the fourth stall beyond the Vice-President's seat. They had come from the Ivy on the West Wall of the Chapel, and had grown under the walls and floor of the antechapel and under the organ-screen, or for a distance of about 20 yards in all.

When we watch the deer peacefully drowsing on a summer afternoon under the shade of the great elms of the Grove, it is difficult to carry imagination back to the times when this was the busy manufacturing quarter of Oxford, the abode of seventy fullers and weavers, and resounding with the clickclack of twenty-three looms. The raw material was brought in barges up the Cherwell, and no doubt the finished cloth was also taken away by water.

Yet even now after prolonged drought the grass burns brown over the foundations of the old houses, the ground plans of which I have thus been able to survey, and have

* It has been suggested that the vapours liberated at the Gas-works are an important factor in the perishing of Oxford stonework. 
yearned to unearth. Three hundred years perhaps have passed since they last saw the light of day.

The grounds behind the College were laid out partly " in Gardaines [both of the bachelors and of the cooks, 1496], Orchardes, Pastures, and Walkes," and partly with a view to the game of bowls, which formed the popular amusement of the seventeenth and eighteenth centuries. Upon the green, Cromwell and Fairfax bowled, and Addison wrote Latin verse.

The following items, mostly extracted by Mr. Macray from the College Accounts, tell their own story of the interest taken in the improvement of the grounds, especially during the seventeenth century and after :

I466-72. Clausura Gardini Collegii.$$
\text { ¿ s. d. }
$$

I5I3. The hedges round "The Walks" repaired.

I531. A tower is mentioned "in virgulto," i.e. in a shrubbery or grove.

1636. Bowling green newly turfed.

1647. Wiggins circumfodienti sphaeristerium . . . . o I6 o

1649. Purgantibus aquarium in arbusto . . . . . o I4 O

" Purgantibus pratum post inundationem . . . . 4 I9 0

" Pro sabulo [ad] reparanda ambulacra . . . . . 060

" Aliis in prato lacunantibus . . . . . . . 400

". Bartlet, lacunanti in pomario Dni Praesidis . . . 080

I660. Pro 200 aceribus majoribus in arbusto inserendis . . 296

„, Pro ulmis serendis ad portas Collegii . . . . o is 6

I66I. Iacobo Bobart, hortulano, per billam . . . . 2 I7 0

Pro arboribus emptis et serendis in ambulacro et arbusto $\begin{array}{llll}3 & 12 & 0\end{array}$

I664. Pro fascibus spinosis ad arbores recent. in arbusto pro-

tegend. . . . . . . . . . . 0 I0 0

I666. Fowler arbores in arbusto et ambulacris plantanti et munienti . . . . . . . . . . I I 8

" Taylor, sedile in arbusto coloranti . . . . . . . 068

I667. I25 trees were planted in the Grove at a cost of . $\begin{array}{rll}3 & 0 & 2\end{array}$

1668. For 90 trees planted in the Grove and meadow . . I 153

I672. Serentibus 88 arbores in arbusto et prato. . . . 6 I0 I0

1673. [Making] ambulacrum medium, de novo . . . .

I674. Reparantibus fossas et ambulachra, item serentibus et

munientibus arbores . . . . . . . . $\begin{array}{llll} & \text { I8 } & 8 & 5\end{array}$

1678. Pro ulmis serendis in arbusto et ambulacro aquatico. . 3 10 0 
678. Famulo Ric Stubbs, $f s . d$.

1678. 'Famulo Ric. Stubbs, serenti, munienti, et riganti arbores in arbusto et pro opere in sphaeristerio . $\quad \begin{array}{lllll} & & 4 & \text { I } & 6\end{array}$

1680. Pluther, fabro lignario, munienti arbores in fronte Collegii satas

" Eidem, pro sedibus in arbusto . . . . . .

" Bobart, etc., arbores serentibus, munientibus, rigantibus, etc., in arbusto, prato et ambulacris . . . . 5050

1683. Stroud et sociis reficientibus ambulachrum in arbusto et prato et plantantibus arbores . . . . .

" Keates et sociis instaurantibus ambulachrum et arbores plantantibus . . . . . • • (?) IO0 0 o

1684. Keate et sociis versus reparationem ambulachri in prato, insolut. superiori anno (remanente $£ \mathbf{1 0 0}) . \quad . \quad .81$ Io 0 I685. Greening, sata plantanti in ambulachro aliaque negotia obeunti . . . . . . . . . . . . 43 I3 II I

1686. Plantantibus in arbusto . . . . . . . . . 20199

I 700. Laborantibus in instaurando ambulachro . $\quad . \quad 378$ I I

I70I. Ordered that labourers be employed in watering and beating the new bank in the water-walks.

I702. Ordered that the walnut trees* be cut out of the mase in grove.

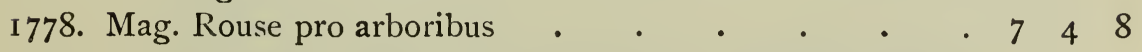

I8Io. Wooden fence before the President's Lodgings replaced by a wire fence.

I820. Plantations of shrubs or trees were ordered to be made in the Walks where necessary.

1824. President's Garden(west of the New Buildings)removed and a new garden made for him "near the Gravel Walk."

1826. Sunk fence made between the Grove and the New Buildings Quadrangle.

1832. Morgan's belt planted in the Angel Meadow.

* An earlier cutting of a walnut-tree is recorded in a lampoon on the President by John Dobson, published Aug. 1663, and quoted in "Bloxam's Register," Choristers, p. 75 :
The tree which walnuts forth did shoot,
Is voted down, both branch and root;
And where bowls ran, there turnips grow;
But from the beginning it was not so.

The tree stood at the upper end of the Grove, and was cut down by the Bursar without the knowledge of the President. It is not true that the bowling-green was turned into a turnip-garden. 
The oldest tree was the famous "Magdalen 0ak," which fell in 1789 in the middle of the night of June 29 , "accompanied by a violent, rushing noise and a shock felt throughout the College." The number of annual rings as counted by R. Paget indicated that it was planted at the beginning of the eleventh century. In the fifteenth, William of Waynflete ordered the

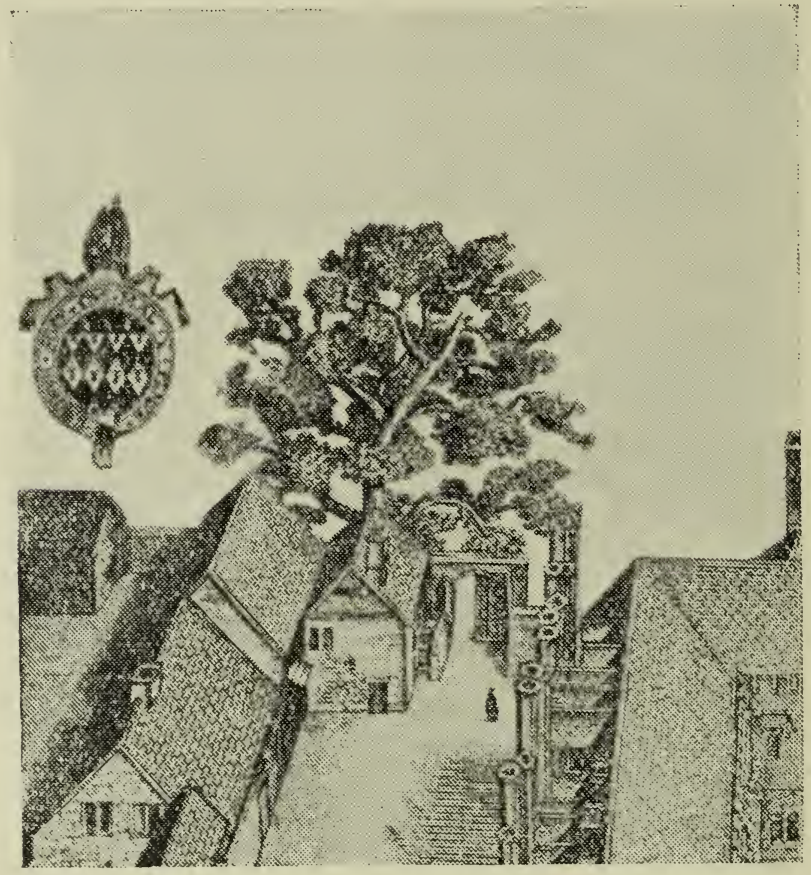

The Magdalen Oak, I675

northern boundary of his College to be marked "right to it." * Two centuries later, measurements showed that "its boughs shoot from the boal fifteen or sixteen yards, which supposing they did spread of equal length from the trunk, like the rays

* Mr. Wilson informs me that he has never been able to find any early authority for this story, and that he believes it to be a local myth, for there is certainly no mention of the tree in the description of the boundaries of the situs collegii. 


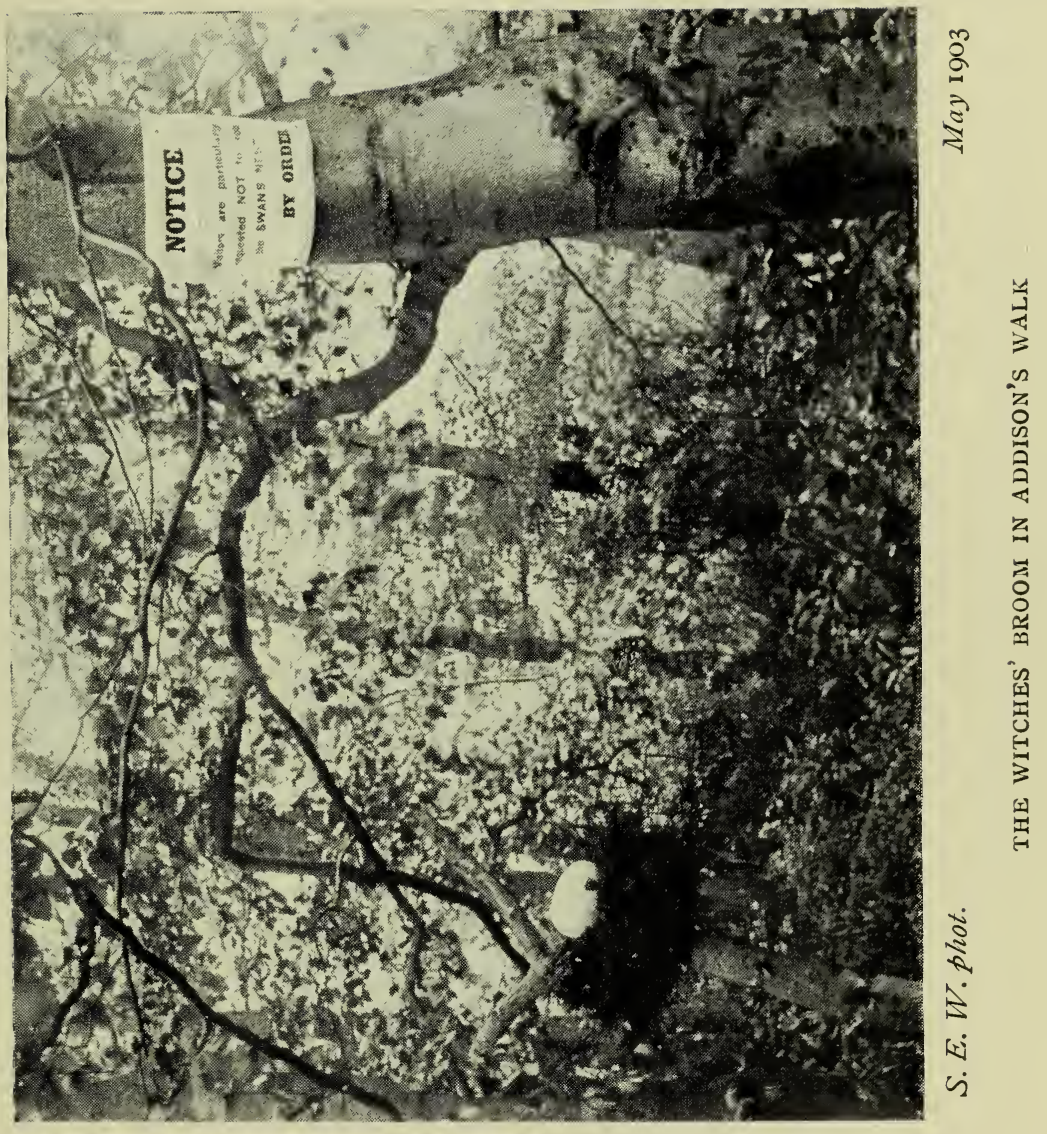



of a circle; the content of ground on which it would drop, would be no less than 768 square yards, whereof allowing as before, three square yards of ground for a horse to stand on (three yards long, and one yard broad, seeming a complete proportion), there might 256 horses stand under that Tree; or allowing as before 2 square feet for a man, 3456 men" (Plot's "Oxfordshire").

It lived for eighty-nine years in the next century, but "On Monday last, without any violence from the wind, the old oak ... fell fortunately into the meadow. . . . The root was entirely gone to powder, so that it dropped by the weight of an arm. ... The people divert themselves in crowding in numbers in the inside of the trunk " (Letter from Dan. Prince in Nichols" "Literary Anecdotes," iii. 699. See (Walker's) "Oxoniana," ii. I55-7 ; Macray's "Register").

The dimensions were: height, 7 I ft. 8 in. ; girth, 2 I ft. 9 in.; solid content $754 \mathrm{ft}$. The shell had for a long time been kept from falling by two or three roots "scarcely so large as a two-inch cable."

A section of the wood used to be among the specimens in the Botanical Museum, and a carved state chair inscribed "Quercus Magdalenensis corruit Festo S. Petri, I789," is in the President's Lodgings, and a snuff-box cut from its wood has lately been presented to the Common Room. Malchair published views of the tree, both standing and as it lay after its fall (Cox's "Recollections of Oxford").

A young Oak to take its place was planted on April 8, 1807, by Robert Penson, Gardener, "on the left as you enter the walk" (Walker's "Flora of Oxford ").

As the oasis is to the wanderers in the desert, so is precise information to the chronicler of trees. The planting of the Elms in the Grand Walk (i.e. those between St. Swithun's Building and the street) is circumstantially described by Wood ("Life and Times," vol. ii., p. 479).

"I680. At the beginning of the month of February the elmes 
between Magd. Coll. and the Greyhound were planted by the fellowes of that College purposely for a shady walke. They were planted anno I657, but caused to be plucked up by [Abraham] Forman and [Edward] Drope, because planted in fanatick times. Set by Mr. Ch. Hawles burser."

Hearne completed the story by an entry in his Diary that"He planted the elms in the gravel walk by Magdalen College," he being a crazy Fellow of the College called Hooper. Dr. Bloxam has also noted an entry in the Liber computi for r 660: "Sol. pro ulmis serendis ad portas Collegii, £o i 8s. 6d."

Mr. Wilson, who has carefully considered the problem, suggests that the trees planted by the "fanaticks" may have been removed in 1660 by Forman and Drope, and have been replaced by new trees, which either did not thrive or did not extend far enough along the walk, thus making a later planting (i680) necessary.

Hooper, having ceased to reside in College, for his infirmity, had gone to live in the Gravel Walk, and so took more interest in the approach to the College than those who lived within its walls. Hearne records that he "applied himself to gardening with wonderful success, digging himself with a man that he constantly hired. He would carry his spade upon his shoulders, and work hard every working day. $\mathrm{He}$ would likewise prune, engraft, and do other things of that kind himself. He raised several nurseries and planted many orchards; but he did all for nothing, for he would never take anything of anybody soever. It was his constant practice to give away trees, etc. ; but then he took care it should only be to the poor and such as were in want, not to others. He was buried in Magdalen College Chapel."

The "unmutilated luxuriance" of the Elms along the Gravel Walks in the thirties helped to make the entry to Oxford one of the most beautiful among cities, but in 1844 one Elm had to be cut down, being decayed, in 1853 another 
fell before a January hurricane, causing grave damage to Pugin's new gateway, and all were lopped. A few years later, at the building of St. Swithun's the whole row was in imminent danger. The workmen had already begun to sink the foundation trenches so near that the roots would have been cut; fortunately, the Bursar of the time had a soul above architects, peremptorily ordered the building-line several feet further back, and the trees were saved for a generation. Last winter the furthermost Elm by the School was cut down. Had it fallen, it would have felled a lamp-post and perhaps a citizen; the College, however, has been assured that it will be replaced by another tree. Three Elms are still standing: from east to west their girths are $12 \mathrm{ft} .9 \mathrm{in}$, I I ft. $7 \frac{1}{2}$ in., and $9 \mathrm{ft}$. Io in.

The old English Elms in the Grove date from the Restoration period, probably from one of the plantings specified in the accounts. Of several that were felled in 1890 one was perfectiy sound. A section showing 220 rings has been mounted as a table-top, and is in the possession of the author - thus agreeing remarkably well with the dates in the accounts of these old trees. A chair presented to the Senior Common Room by Mr. Chapman was cut out of the wood of the same tree, and the thick table-tops in the College Kitchen are from a tree of similar age. The first Elms planted in the Grove may have been planted about the time of the foundation of the College, 1467 , for in 1677 Plot stated that-

"There is a great old Elm growing near the North-east corner of the Bowling Green in Magdalene College Grove, disbarked quite round, at most places 2 foot, at some at least a yard, or 4 foot from the ground; which yet for these many years past has flourish'd as well as any Tree in the Grove."

Like the greater number of our Elms this was in all probability Ulmus campestris. But the giant of the race was the great tree blown down in a snowstorm at mid-day on 
Wednesday, April 5, IgIr, now believed to have been the largest timber tree in all Britain. It was a Wych or Broadleaved Elm, U. montana, characterised by the spreading habit of its main branches, by the absence of the tall straight bole so characteristic of the Common Elm. The leaves, too, are different, being larger in the Wych Elm.

As to its measurements, we are not quite confident that all the published details (Wilson's "Magdalen College," p. 280) are correctly assigned to this tree. We have seen evidence that the early measures were those of another tree (A) probably of the same age, which fell down in $186 \mathrm{I}$ or soon after. These measures were made by or for Dr. Daubeny, and have been attributed to our Great Elm (B).

ELm A.*

GIRTH

GIRTH

$\begin{array}{lrr} & \text { At } 5 \mathrm{ft} \text {. from ground } & \text { At } 2 \mathrm{ft} \text {. from ground } \\ \text { I83I. } & 2 \mathrm{It} .0 \text { in. } & 27 \mathrm{ft} .4 \mathrm{in} . \\ \text { I86I. } & 23 \mathrm{ft} \text {. O in. } & 27 \mathrm{ft} .9 \mathrm{in} .\end{array}$

Estimated contents, I,092 cubic ft., without small branches.

Elm B.*

GIRTH

At $5 \mathrm{ft}$. from ground

I 866.

$23 \mathrm{ft} .9$ in.

I 866 or I867. $25 \mathrm{ft} .6 \mathrm{in}$.

I 899 .

$26 \mathrm{ft} .5 \mathrm{in}$.

I9IO.

$28 \mathrm{ft} .3$ in.

Height, $\mathrm{r} 30 \mathrm{ft}$.

.$\quad 143 \mathrm{ft}$.

In February of I9I I the College was informed that Mr. Elwes of Colesbourne had examined the Elm with an expert (Mr. Havelock), and that its cubic contents were roughly estimated at 2,000 cubic ft. by quarter-girth measure, without any bark allowances; a size only surpassed, according to Mr. Elwes' opinion, by one other English tree---the Oak at Bevis Castle.

* Authorities : 1831, Dr. Daubeny, Botanical Notes, MS. in Magdalen Library, and Walker's "Flora of Oxford"; I86I, T. Hopkins; I866, T. Hopkins ; 1886, O. W. Holmes, "Hundred Days in Europe," I887, p. I2I ; I899, R. T. G. ; I9II, T. Whale, who found the girth at the base to be $37 \mathrm{ft} .6 \mathrm{in}$., and at the fork ( $20 \mathrm{ft}$. high) to be $3 \mathrm{I} \mathrm{ft}$. 


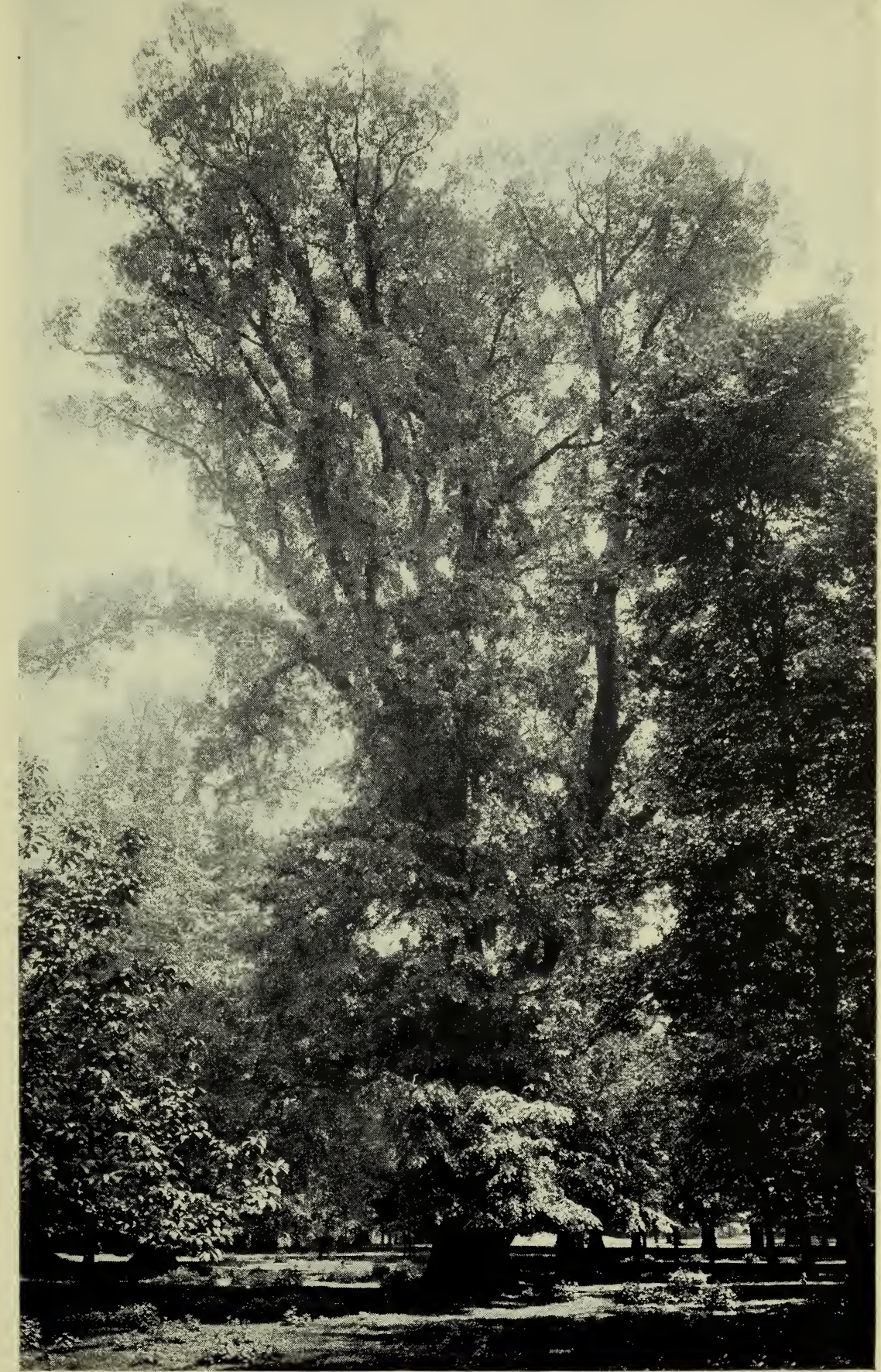

H. W. T. phot. 


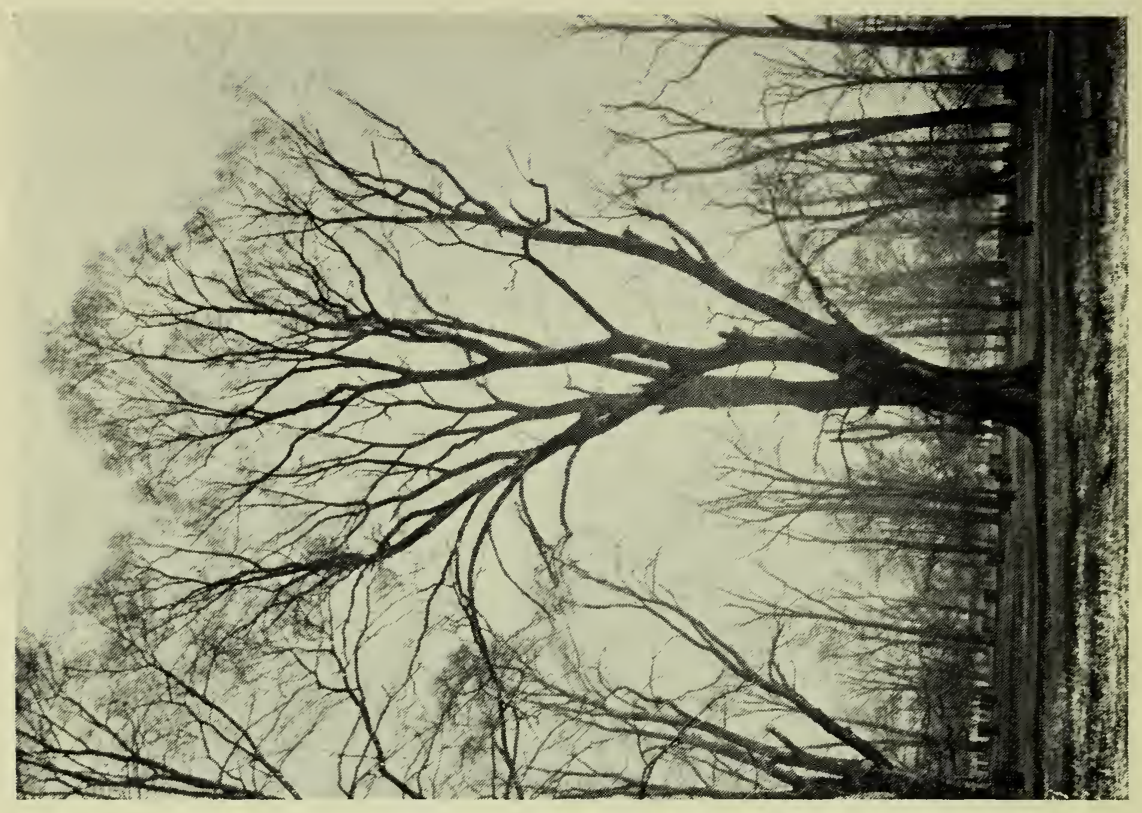

$R$
0
0

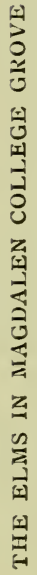

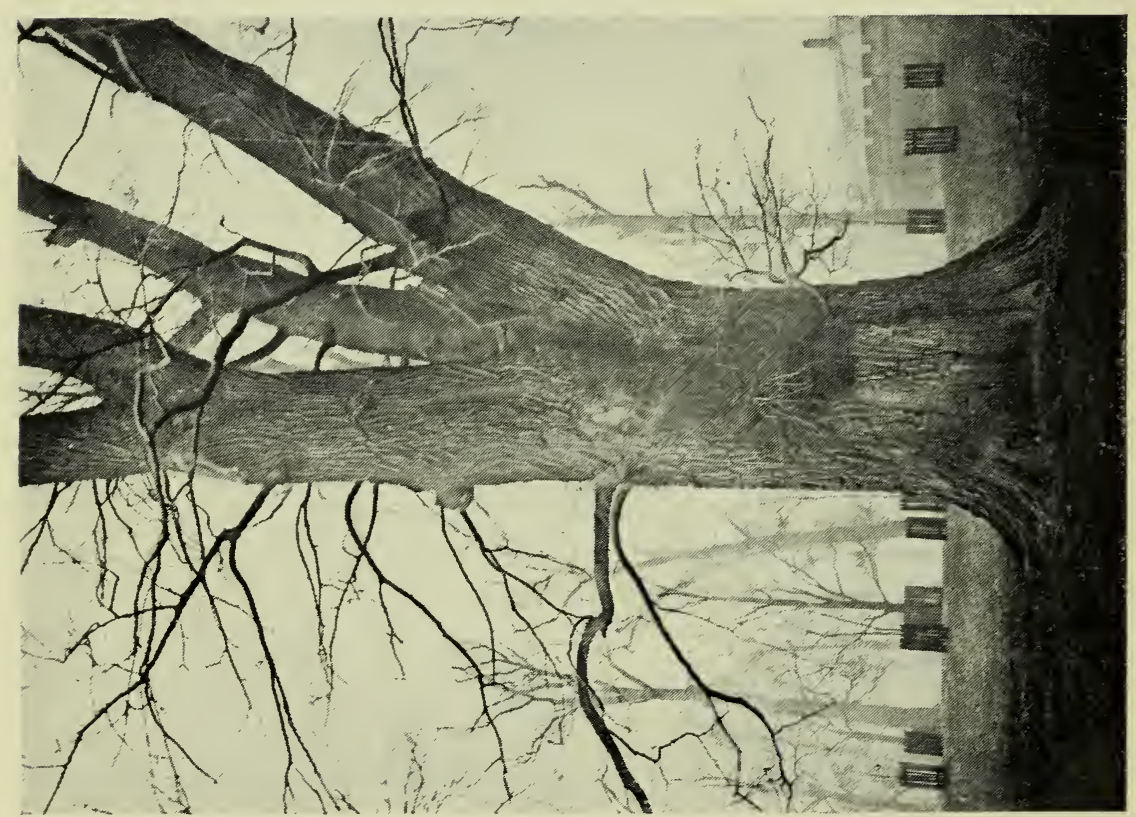




\section{MEASUREMENTS}

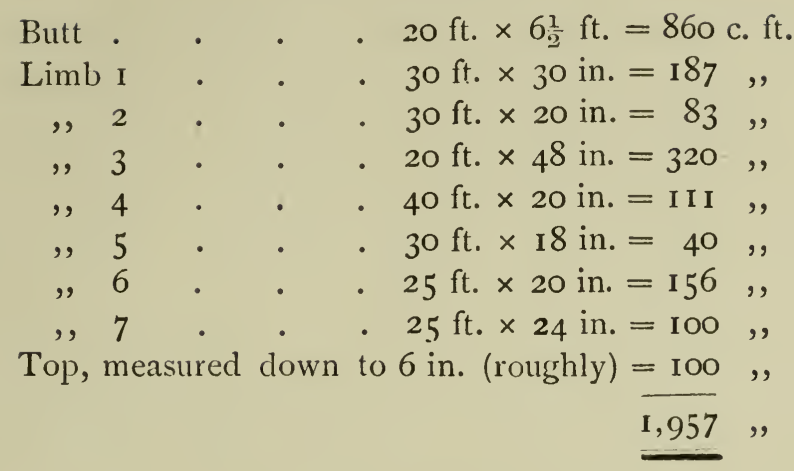

A large Elm, having a girth of $22 \mathrm{ft}$., is mentioned by John Wesley (Journal for $\mathrm{I} 782$ ) as growing "in Magdalen College Walk." It is not impossible that he might have been referring to either of the above-mentioned trees or to a tree coeval with them.

The fallen tree is so rotten in the interior that it is impossible to count annual rings, but Sir William Schlich is of opinion that it was at least 300 years old. If so, it might have been one of the very few trees spared by Cromwell's soldiers for the purpose of hanging Royalists from.

The largest surviving Wych Elm in the Grove has a girth of $22 \mathrm{ft}$. I in. at $4 \mathrm{ft}$. from the base.

A Mulberry and an Elm were planted in the Grove by Prince Christian Victor on November I 7, I898, about two years before his death in the Boer War. Both trees are doing well, their girths being now I ft. 3 in. and I ft. 6 in. respectively.

In front of the President's Lodgings stood a venerable Acacia, "divagating in three mighty stems, of late years carefully propped." Once, when Dr. Routh was at Tilehurst, word was sent that a heavy gale had blown the tree down. "Then let it be put up again," said the President. It was pulled up by ropes, laid over the roof of the Lodgings, and lived for many years, and, as Mr. Wilson informs me, was, when he first saw it, still capable of producing a good crop of leaves 
and a certain amount of flower. The tree shown in drawings of the west front of the College between the two towers seems to have been a Birch. On the other side of the Lodgings, near the Library, are a Plane and a Birch, planted in I80 I by Henry Philpotts, afterwards Bishop of Exeter. The former girths $\mathrm{I}_{5} \mathrm{ft}$. I in.; the latter, $5 \mathrm{ft} .3$ in. A Chinese Crab Apple, Pyrus spectabilis,* by the New Buildings measures $4 \mathrm{ft} .4$ in.

Near the kitchen, by an untidy rockery, is a tree which I have always believed to be Cerasus padus, the Bird Cherry, but it may be an allied species. Trunk-girth, $3 \mathrm{ft}$. Io in.

Before the end of the seventeenth century Celia Fiennes mentions "a very fine gravel walk, two or 3 may walke abreast, \& Rows of trees on either side, \& this is round a water $w^{\text {ch }}$ makes it very pleasant "-so pleasant, that to keep it from being flooded it was raised about I70I, and was so much approved that Wood wrote the following eulogy on the College :

"Whose Grove \& Gardens, enclosed with an embattled wall by the Founder, are emulous with the gardens of Hippolitus Cardinal d'Este, so much famoused and commended by Franciscus Scholtus in his Itinerary of Italy: Go into the Water-walks, and at some times of the year you will find them as delectable as the banks of Eurotas, which were shaded with bay trees, and where Apollo himself was wont to walk \& sing his lays. And of the Rivers here, that pleasantly and with a murmuring noise wind and turn, may in a manner be spoken, that which the people of Angoulesme in France were wont to say of their river Touvre, that 'it is covered over and chequered with swans, paved \& floured with troutes, and hemmed \& bordered with crevisses.' Such pleasant meanders also shadowed with the trees were there,

* Loudon has placed it on record that a $P$. spectabilis grew in the Botanic Garden to a height of $25 \mathrm{ft}$. in thirty years : the diameter of trunk was 10 in. and of head $20 \mathrm{ft}$. It would have been planted about 1806, and our tree must be of about the same age. 
before the civil distempers broke forth, that students could not but with great delight accost the Muses."

The part afterwards associated with the name of Addison is the straight walk along the north side of the Meadow. There the eminent historian, John Richard Green, as a boy, "thought less of Addison than of wasps' nests and crawfishing."

The principal trees in the "green natural cloister of our Academe" are Elm, Beech; Horse-chestnut, Hornbeam, and Oak. The largest Oak, near the end of the New Buildings, girths 9 ft. 3 in. A tall Lombardy Poplar growing on the steep side of the bank at the western end of Addison's Walk exhibits a fine example of a buttressed stem. The trunk is + -shaped, and measures $4 \mathrm{ft}$. across, and is admirably adapted to withstand the strains put upon it.

From the landscape gardener's point of view, the beauty of Addison's Walk was greatly impaired in I906, when the position of the ditch was moved and a bank of earth was thrown against the original steep south bank of the Walk. The effect of a narrow plantation on the side of a steep bank was better than that of a wider plantation on a more level surface.

'The black swans were presented by the Vintners' Company in July, r 904 .

When the new walk from Addison's Walk to King's Mill, with two bridges across the Cherwell, was commenced about I867, in accordance with the plans of Mr. T. H. T. Hopkins, some interesting trees were planted along what is now known as the "Fellows' Walk."

The present dimensions of the largest of the trees may be of interest a century hence. We give them in order from the Walks to the King's Mill Gate:

Maple, $6 \mathrm{ft}$. 10 in.

Lombardy Poplar, 7 ft. 6 in.

Plane, 5 ft. 4 in.
Red Horse-chestnut, 4 ft. 6 in. Variegated Sycamore, $4 \mathrm{ft} .6$ in. Lime, $4 \mathrm{ft}$. 
Ash, 4 ft. 6 in.

Plane, 4 ft. 8 in.

Oak. $2 \mathrm{ft}$. I in.

Cut-leaved Beech, I ft. 3 in. in diameter.

Oak, I ft. I I in.*
Wellingtonia, $6 \mathrm{ft} .8$ in. Lombardy Poplar, $6 \mathrm{ft}$. Lawson's Cypress, $3 \mathrm{ft} .8$ in. Wellingtonia, $8 \mathrm{ft}$. 6 in. Pinsapo, $5 \mathrm{ft} .6 \mathrm{in}$.

More planting of trees and shrubs in the Grove and Walks took place in $\mathrm{r} 87 \mathrm{I}$, so that possibly some of the trees in the list date from that year. The younger trees standing out in the Meadow were planted in 1898 by Mr. C. R. Carter, who was then Home Bursar, and to whom we owe the first introduction of many bulbs by the side of the IValks.

Over a hundred species of native plants have been recorded as growing in the Magdalen IVater Walks. The first record of any wild plant is that of "le dokks," which were got out of the Meadow in I532. The Fritillary is now preserved in the Meadow.

I know what white, what purple fritillaries

The grassy harvest of the river fields

Above by Eynsham, down by Sandford, yields.

Certain wall-plants have a less secure tenure. Arabis turrita from the S. of Europe used to flourish on the Long IVall of the Grove with the Oxford Ragwort, but has been destroyed by the repointing of the masonry. Aster paniculatus from N. America, Poa nemoralis, and the Hawkweeds, Hieracium pellucidum and $H$. sciuphilum, are interesting plants.

Two rare mosses, Cinclidotus brelissoni and Eurhynchinm speciosum, have been recorded by Mr. Napier (1910) from Addison's Walk.

The positions of the trees of Magdalen are indicated in E. H. New's print (1906-9), but the drawing of the trees is very poor.

The elaborate carpet-bedding at New College in the

* This Oak was grown from an acorn from Tulney Wood; planted by J. E. Henderson, Bursar. It was about $2 \mathrm{ft}$. high in $1877-8$ (H. A. W.). 
seventeenth century has already been noticed. The floral coats of arms and the mountain with walks are clearly shown in Loggan's print of 1675 , and the general impression of twenty years later is thus given by Celia Fiennes:

Ye Garden was new makeing, there is a large bason of water. In the Middle there is little walkes and mazes, and round mounts for the schollars to divert themselves . . . and here they may Live very Neatly and well if Sober, and have all their Curiosityes they take much delight in, greens of all sorts, Myrtle, oringe and Lemons and Lorrestine growing in potts of Earth, and so moved about from place to place and into the aire sometymes. There are severall New Lodgings added and beautifyed here, the Gardens also wh $^{\text {th }}$ gravell and Grass walkes, some shady and a great Mount in the Middle $\mathrm{w}^{\mathrm{ch}}$ is ascended by Degrees in a round of Green paths deffended by greens cut Low, and on $y^{\mathrm{e}}$ top is a summer house. Beyond these Gardens is a bowling-green, and round it a Close shady walke, walled round and a Cutt hedge to the bowling-green.

The garden owes much to the old Town Wall, but much, too, to its noble trees. The two large Elms girth $\mathrm{I}_{5} \mathrm{ft} .4 \mathrm{in}$. and $\mathrm{I} 3 \mathrm{ft} .3 \mathrm{in}$. respectively; the Tulip Tree has a trunkgirth of $5 \mathrm{ft}$. 6 in.; the largest Horse-chestnut, $12 \mathrm{ft} .7$ in. ; and the Copper Beech, $8 \mathrm{ft}$. I in.

When New College was visited by "H. E." in the summer of 1887 , the fine Limes had not yet burst into blossom, and, thinking of the bees which would visit them, he remarked to the gardener, "What a buzzing they will make presently." "Ay," replied the latter, "they buzz almost as beautiful as the organ in the chapel." At $4 \mathrm{ft}$. from the ground the girths of the eight Limes are $\mathrm{r} 3 \mathrm{ft} .4$ in., I I ft. 6 in., $8 \mathrm{ft} .6$ in., I $\mathrm{ft} .8$ in., ro ft. 7 in., $8 \mathrm{ft}$. 6 in., ro ft. $\mathrm{s}$ in., and I $\mathrm{ft} .3$ in.

The largest Birch in the garden girths $5 \mathrm{ft}$. Io in., and a Mountain Ash, 4 ft. 2 in. I have not been able to ascertain the exact age of any of the older trees; but my friend Mr. Joseph, to whom I am obliged for the measurements, writes that the late Warden remembered the planting of the Catalpa, when he had not long been a Fellow, i.e. I 830, which now has a girth of just over $8 \mathrm{ft}$. So strictly observed (by 
the authorities) was the rule against picking the flowers, that it is said that even the Warden (Dr. Sewell) himself was not aware of how soon they fell when plucked and put in water, until he tried the experiment with some which he had forcibly taken from an American visitor.

He had the branch taken away from the tripper, and said to one of the present Fellows (A. F. W.) that it had enabled him to discover, what he had long wanted to know-the behaviour of the flowers when placed in water. For all those years-for the incident occurred about 1898-he had subordinated his curiosity to his respect for the tree! There were younger members of the College who could have told him that the flowers would not live in water.

A Cedar, so Professor Turner informs me, was planted in memory of Bryan Alt, who left a sum of $£$ Io in his will for the garden.

Many of the trees have been admirably planted to illustrate the exceeding great value of trees as screens at the back of ugly buildings, which, like so many others in Oxford, are the works of modern architects, who closely resemble those described by Pugin :

Some raise a front up to the church

Like old Westminster Abbey;

And then they think the Lord to cheat,

And build the back part shabby.

The identity of one of the trees was for long a matter of controversy in College, and the following type of dialogue was not an uncommon one in the Common Room :

"The Spanish Elder" (spoken with assurance) "is not looking very well to-day."

"No, the American Oak" (spoken with polite but frigid emphasis) "has been going off of late."

"I have noticed that the Spanish Elder," etc.

The tree did not long survive the misunderstanding, and its real name is still a mystery to us. 
"These gardens of New College are indescribably beautifulnot gardens in the American sense, but lawns of the richest green and soft velvet-grass shadowed by ancient trees that have lived a quiet life here for centuries, and have been nursed and tended with such care, and so sheltered from rude winds, that certainly they have been the happiest of all trees" (Hawthorne's "English Note-book").

All Souls College can boast the tallest Rowan in Oxford, a slender sapling as tall as the Codrington Library building. The Sycamore, $7 \mathrm{ft}$. girth, overhangs, and is a great ornament to the High Street.

Brasenose College. Hearne tells us that the quadrangle "was once a garden, which was a delightful and pleasant shade in summer-time, but was cut down by direction of the Principal and some others, purely to turn it into a grass plot and erect some silly statue there" [Cain and Abel].

"There was a garden, too, attached to our College, but nothing was ever sown in it, save wild oats and exhausted 'weeds'; and I can only remember a single window which was beautified with flowering plants, and this 'because' (as I was assured on inquiry, though I was quite unable to understand the inference) 'the occupier was going over to Rome" (S. Reynolds Hole, "A Book about the Garden "). S. R. H. was at Brasenose between I840 and I 844 .

But although Brasenose College now owns no trees within its walls, it is the proprietor of one of the finest small private gardens in Oxford, at Grandpont. A list of dimensions of the older trees is given on p. 248.

Exeter College has the joy and the responsibility of having one side of the Bodleian Library in the garden.

On the other hand, porers over Bodleian manuscripts can rest their tired eyes on the restful green beneath them. Sir Christopher Wren's massive but beautiful buttresses all covered with ivy, and the fine Robinia ( $\mathrm{I} \mathrm{ft} .6$ in.) on the lawn, compose a group of unique charm among garden views. 
The site of part of the garden was covered in the fourteenth century with small halls which became the property of the College. A portion of the garden did not at first belong to the College, but was hired from Balliol. In one of the leases, for forty-one years from Lady Day, I58I, it was stated that "Exeter shall not make any bowling allee or tennisse court which may be noisome to students, or any hogsty or dunghill or any other filthy savour" (Boase). The garden had been "made square" with a wall in I 573. The winding path has been said to have been planned by Hogarth to illustrate his line of beauty. The Rector informs me that the exact date of the terrace is unknown, but that he believes it to have been thrown up early in thei eighteenth century, when the Radcliffe was erected. A quit rent is still paid to All Souls College, and so it is probable that some of the ground last enclosed belonged to that College.

At the further corner, on the terrace, is Heber's Horsechestnut ( I I ft.), so called because it shaded Reginald Heber's rooms in Brasenose (circ. I800-3). It stands high above the road, and, when not cut back, reaches almost across Brasenose Lane. There is a saying that when the branches of the tree touch the buildings of Brasenose, Exeter will bump B.N.C. on the river: and this actually occurred in $\mathbf{I} 895$. Near it are two old Pear-trees ( $5 \mathrm{ft} .6$ in. and $4 \mathrm{ft} .2$ in.). In the border along the road are a Cut-leaved Alder (6 ft. 3 in.) and a newly planted collection of shrubs, none apparently of much interest, as yet.

One of the Fig-trees against the College building is associated with the name of Kennicott, Radcliffe Librarian, I767-83, and a Fellow of Exeter until I77I, but none of the branches trained on the wall date from his time. The older branches were all killed down to the root by the severe winter of 1860 . There is a tradition that the first Fig here was introduced by Maundrell, Fellow of the College, who had been chaplain at Aleppo in 1695, and thus, like Pococke 
of Christ Church, and Sir T. Roe of Magdalen, was one of the links between Oxford and the East during the seventeenth century.

Two young Birches near the Rector's House measure $2 \mathrm{ft} .2$ in. and $\mathrm{I} \mathrm{ft.} 7$ in. respectively.

Lincoln College is celebrated for its Vine, the story of which is told by Mr. Warde Fowler as follows :

"In the inner quadrangle of Lincoln College the visitor may notice two Vines climbing the old grey walls. They usually produce a few bunches of grapes, some of which are brought into Common Room on the College 'chapter-day,' or halfyearly meeting of Fellows, on November 6. 'These Vines are not now in their original place, nor is it likely that they are direct descendants of the original stock; but there is little doubt that one Vine at least has been trained on the College walls since the year 1474 .

"In that year the second Founder, Thomas Rotherham, Bishop of Lincoln and Visitor, paid a visit to the College founded in 1429 by another Bishop of Lincoln, Richard Fleming. He found it in a miserable and decaying condition, owing to insufficient endowment and other misfortunes; only a part of the present front quad had been built. The Rector of that day made a successful appeal to the Visitor, a man of wealth and importance even then, and afterwards Archbishop York, of which appeal the Vines remain as a happy memorial. He preached before him from Psalm lxxx., I 4, I5. 'Behold, and visit this vine, and complete it which Thy right hand hath founded' (translated from the Latin which he used). The Bishop was moved, and became the second Founder of the College; and to commemorate his generosity and the preacher's text, a Vine was planted in the quadrangle, which was soon to be completed. When the new Chapel was built in 1628, the Vine was apparently transplanted to the inner quadrangle, where its representatives are still to be seen, as described above." 
Opposite the College Lodge grows a Plane with a trunk which measures about $3 \mathrm{ft}$. 6 in. to $4 \mathrm{ft}$. in diameter.

Trinity College Gardens are laid out in a somewhat formal style suited to the architecture. They are famous for the avenue of Lime-trees, made early in the eighteenth century, which have been cut so as to meet one another and form a leafy trellised vault over a shady walk. The periodical cutting back of the branches encourages tuft-like new growths of twigs, which have been compared to the bosses on ribs of a gothic ceiling. The trunks are the pillars, and the sun's rays, slanting through the foliage, make on the ground the effect of light through stained-glass windows. The largest trees in the avenue only girth about $4 \mathrm{ft}$. 3 in., and it is not easy to believe that the tables for a Commemoration breakfast were spread under them in 1787 .

Parallel is a line of Yews, largest about $5 \mathrm{ft}$., but larger still are the pair near the Iron Gates, one with a straight trunk, $5 \mathrm{ft}$. Io in. round and over Io $\mathrm{ft}$. in height, the other springing from a bole $3 \mathrm{ft}$. $6 \mathrm{in}$. across. Two Yews inarched may be seen near the St. John's boundary, not far from the Robinia (6 ft.).

But most noteworthy of all is the magnificent Wistaria, planted about I863, which extends through a dense growth of Ampelopsis along the greater part of two sides of the quadrangle, for a length of $\mathrm{I}_{5} \mathrm{ft}$. It may therefore claim to have leaves further from the root than is the case with any other plant in Oxford, and it would probably have gone further had it not been for the Ampelopsis,

ubi aëra vincere summum

Arboris haud ullae jactu potuere sagittae.

VIRGIL, "Georgics."

In the old orchard of the Cottages in the front quadrangle are two Pears of $4 \mathrm{ft}$. girth, and Apple-trees of $3 \mathrm{ft}$. I I in. and $3 \mathrm{ft}$. Io in. The Catalpa, which has started branching 
near the ground, girths $4 \mathrm{ft}$. Mr. Raper informs me that it was planted about 1889 and was originally a Golden Catalpa (with larger leaves, grafted on to an ordinary stock), but was broken one night by undergraduates below the graft. It has grown rapidly. The young Birches near the Lodge now measure about $\mathrm{I} \mathrm{ft} .9$ in.

Balliol College contains the wreck of the largest Mulberrytree in a College garden. The short hollow trunk has a girth of $7 \mathrm{ft}$. Io in., but is not strong enough to support the branches without the assistance of props. A younger tree, planted by Mr. Woollcombe, girths $3 \mathrm{ft}$. I I in.; and will in time take the place of the large one. Near by, the Ailanthus measures $4 \mathrm{ft}$. 6 in. round the trunk. The third Mulberry was planted in 1875 , and the Lime in the following year. The latter tree has done well, its present girth being $3 \mathrm{ft}$. 6 in. Near the Hall is a Weeping Cerasus virginica. The big Plane measures i $\mathrm{ft}$. in girth.

The present Bursar, Mr. Edward Hilliard, has much increased the interest of the collection by adding the following trees, several of which are not to be easily found elsewhere in Oxford :

In I906. 4 Wistarias on the Old Library.

In Dec. 1908. 9 free-flowering sorts of espalier Apples, and Catalpa bignonoides,

Cerasus serrulata,

$\begin{array}{ll}\text { " aurea, Amelanchier ovata, } \\ \text { Crataegus prunifolia, } & \text { Euonymus latifolius, } \\ \text { C. macrantha, } & \text { Viburnum plicatum (dead). }\end{array}$

These trees were chosen because they flower in or about the last week in May.

In 1909. Birch in the Back Quadrangle.

In I9ro. 2 Hornbeams in the Back Quadrangle, and Cotoneaster frigida.

In I9г. Ceanothus veitchianus.

Magnolia soulangeana, by the steps of the Hall.

Davidia involucrata, a plant not well-known in Oxford. 
There is a good Ceanothus veitchianus in the Fellows' Garden and a red-leaved Vine has been most appropriately and invitingly trained round the entrance to the Common Room.

St. John's College. A good example of what may be accomplished within the limits of a College garden may be seen at St. John's College. The garden was laid out by "Capability" Brown* and Repton, but the present Bursar has taken full advantage both of his official position and of the possibilities of the soil and aspect, to cultivate many beautiful and interesting Herbaceous plants which are an ornament to the garden and a delight to visitors, and have greatly enhanced the high reputation of St. John's Garden. It is not every College Bursar who is so enthusiastic a horticulturist $\dagger$ as Mr. Bidder.

The gardens have been steadily improved "under the sober direction of discriminating taste" (Ingram).

I woll nat long hold you in fable

Of all this garden delectable

I mote my tongue stinten nede,

For I ne may withouten drede

Naught tellen you the beautie all,

Ne halfe the bountie therewithal.-CHAUCER.

A "Catalogue of Herbaceous Plants cultivated in the Gardens of St. John's College, Oxford," has been printed. It was revised in 1890 and enumerates about 350 species.

* This remarkable personage, born 1716 , after ten years in the service of Lord Cobham at Stowe, settled in I749 as consulting landscape gardener. George II. appointed him Head Gardener at Hampton Court. He was High Sheriff for Hunts and Cambridgeshire I770, and died I783. His work was not " cheap," cf. Cowper, "The Task," bk. iii.

$\dagger$ Nor even every Bursar of St. John's! See a manuscript book of poems in the British Museum, MS. 37684 :

On $y^{\mathrm{e}}$ Burser of St. John's Oxon cuttg down a fine Row of Trees.

Indulgent Nature to each Kind bestows

A secret Instinct to discern their Foes

The Goose, a silly bird, avoids y $y^{\mathrm{e}}$ Fox

Lambs fly from Wolves, \& Saylors steer from Rocks

A Thief $y^{e}$ Gallows as his Fate foresees,

And bears a like Antipathy to Trees.-(?) W. TAylor. 
This, however, has long been obsolete, and the number of species on the rockery alone would approach I,o00.

The oldest trees in the garden are the Elms, the largest of which, now a mere stump, measures ${ }_{15} \mathrm{ft}$. round the trunk; another near the Common Room has a girth of $\mathrm{x} 2 \mathrm{ft}$. 10 in. and is about $20 \mathrm{ft}$. in height, having been polled in 1909. And it is appropriate that there should be Elms at St. John's, for the College was founded near a triple Elm. Salmon, in I 748, noted that the walks were planted with Dutch Elms (stunted pollards), and that the walls were covered with evergreens.

The timber of next largest growth is that of the Horsechestnuts, several of about the same age, measuring from Io ft. to $9 \mathrm{ft} .4 \mathrm{in}$. in circumference. The best Lime has a fine trunk of $9 \mathrm{ft} .8 \mathrm{in}$; the two Evergreen Oaks, $6 \mathrm{ft} .7$ in. and $5 \mathrm{ft}$. 10 in.; Yew, $5 \mathrm{ft} .7$ in.; Cedar, 7 ft. 9 in.; Scotch Fir, 3 ft. 9 in.; Laburnum, $4 \mathrm{ft}$; ; and a remarkably tall Thorn has a trunk of $24 \mathrm{ft}$. in height and $4 \mathrm{ft} .3$ in. in girth. Close to it under the south wall are a Dimorphanthus mandshuricus, a species of Aralia, stem girth I ft. 7 in., and some large Juniper bushes, $7 \mathrm{ft}$. to $8 \mathrm{ft}$. high. Another Juniper nearer the rockery forms a fine bush $12 \mathrm{ft}$. across, its stemgirth being I ft. 4 in. Near it is a clumpy Thuja pygmaea, a bush $5 \mathrm{ft}$. through.

Growing against the College are the curious climbing Polygonum baldschuanum, and a Wistaria, trunk I ft. $7 \frac{1}{2}$ in. ; and against the wall facing south, a Fig, one stem of which girths I ft. $4 \frac{1}{2}$ in.

In the "Dolphin " Garden are old Pear-trees, $5 \mathrm{ft} .2$ in., and $3 \mathrm{ft}$. I I in., a Mulberry of $6 \mathrm{ft} .7$ in., and a Fig of $\mathrm{ft}$. 10 in.

T. F. Dibdin, circ. I795, records that with Johnson and Boswell he "used to sit hour after hour, and day after day, in our groves or gardens-a very paradise of their kind,"-a paradise depicted upon Professor Oman's fan, a photograph of which was published as frontispiece to the "Studies in Oxford History," vol, xli. of the Oxford Historical Society. 
Worcester College. 'The gardens on the south side of the College buildings as far as the river at Hythe Bridge, and extending north-west along the river, were purchased in $\mathrm{I} 74 \mathrm{I}$. In 1788 the land now occupied by the canal and towing-path from the north end of the College field to Hythe Bridge was sold to the Canal Company.

The pond was made apparently shortly before $18 \mathbf{I} 7$, and was stocked with nineteen shillingsworth of fish on Nov. 7, I8I7, and also with "tench for lake," April I6, I8I8, and Dec. $4, \mathrm{I} 8 \mathrm{I} 8$, at $2 s$. and 5 s.

From I 8 I 7 to I 822 , a lot of planting, laying of turf, and making of walks was done, and an item in the accounts, "carriage of beeches," may have included the big Copper Beech and also the Beech in the Fellows' Garden; and thus, as Mr. F. S. Lys, to whom we are indebted for this information, has suggested, we have a probable clue to the age of the trees.

The old Apple-tree, $45 \mathrm{ft}$. in height and $5 \mathrm{ft} .7 \mathrm{in}$. in girth, is, so far as we know, the largest in Oxford. The Tulip Tree near by, girthing 4 ft. 9 in., was planted by G. Bell when Bursar about i 860 (F. J. L.).

The finest trees are undoubtedly the Ailanthus; the male tree has a fine tapering trunk $9 \mathrm{ft}$. in girth, and the female is somewhat smaller. Suckers from the former, as in the Botanic Garden, have come up at a distance of 30 yds. A third Ailanthus, which stood near the Copper Beech on the "Stage," where many an open-air play has been performed, has just been felled. We counted 84 annual rings, and noted that the growth of the tree received a check forty years ago. Other noteworthy trees are the Horse-chestnuts, girth I I ft., and a Plane $\mathbf{I} 2 \mathrm{ft}$. in girth. The largest Box has a diameter of 8 in. for a short length. A Walnut in the south-west corner of the :garden measures ro $\mathrm{ft}$. round.

Winding walks lead along the margin of the informal lawn to the lake, upon the margin of which grows a fine Horsechestnut whose large branches stretch out over the water. Near 
the gate is an Alder, the short trunk of which has a girth of $\mathrm{ro} \mathrm{ft}$., but it soon divides into three very tall and straight limbs. Not far from the water are a Walnut, an Ilex (far more picturesque with its stunted trunk and seven limbs than a forester's tree), and a Weeping Ash.

Two large Willows, one of ${ }_{5} \mathrm{ft}$. girth, grow upon the canal bank, by the side of the walk leading to the north end of the cricket field, where the present Bursar is planting a variety of interesting trees along what promises to be a picturesque extension of the walk, as well as a much-needed screen. A Poplar on the east side girths $14 \mathrm{ft} .4$ in.

In the Fellows' Garden, which is believed to have been laid out in $18 \mathrm{r} 3$, there are the fine Beech ( $8 \mathrm{ft} .9$ in.) already mentioned, a Robinia ( $9 \mathrm{ft}$. I in.) which seems to be nearing the limit of its life, and a Mulberry of $6 \mathrm{ft}$. 6 in., with an epiphytic gooseberry living upon it.

In the Provost's Garden there are a fine Ash (3 ft. 7 in.), and a Hornbeam of $5 \mathrm{ft}$. Io in.

Wadham College Garden was originally laid out in the grotesque taste of the seventeenth century, with clipped parterres and an artificial mount, shown in Loggan's engraving, which lasted at least as late as 1733 . The garden was brought into its present "romantic" form at the end of the eighteenth century under the direction of Shipley, who was employed by Warden Wills.

The sole surviving Cedar of Lebanon brings back painful memories of the loss of its companion on April 25, 1908, when an unexpected fall of clinging snow brought it down.*

* As the Warden contemplated the fallen tree, there fell from his lips the Sophoclean reflection-

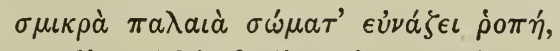

while the Subwarden relieved his feelings in an epigram :

Non hiemi vires te, maxima, rumpere veris

Formosam tacitae surripuere nives,

It had been the scene of a story well known in Wadham, about a Scholar of the College who was once found sitting in the tree in scanty raiment. $\mathrm{He}$, long afterwards, became an eminent Bishop. 
The pair figure in all picturesque views of the garden side of the College. In the fallen tree iro rings were counted, and its girth at the ground was $9 \mathrm{ft} .6$ in. (F. A. D.). The trunkgirth of the survivor is $8 \mathrm{ft}$. 6 in. A young tree of $2 \mathrm{ft} .9$ in. girth stands near.

The finest tree at the present time is undoubtedly the Purple Beech, I I ft. 6 in. in girth, and with a spread of branches of something like 13 yds. radius. Close by are an Evergreen 0ak, now $8 \mathrm{ft}$. 6 in. in girth, and an aged Robinia.

Other trees are an Ailanthus, a fine Magnolia acuminata (3 ft.), a Red Wood, Sequoia sempervirens* ( $4 \mathrm{ft} .4$ in.), and Broussonettia papyrifera, all among the finest of their kind in Oxford. By the entrance to the garden is a weeping Robinia hispida inermis grafted on a stock of $\mathrm{I} \mathrm{ft} .3$ in. girth. In the middle are some old Limes, and in the eastern border a Ginkgo. North of the Chapel is a Gleditschia ( $3 \mathrm{ft}$.), while to the south a Laburnum forms a fine clump springing from a bole, the largest of its kind in Oxford. The later flowering Scottish Laburnum may also be seen here.

The Cockspur Thorn, Crataegus crus galli from N. America, covers with its pale green shining leaves a space of lawn I4 ft. or $15 \mathrm{ft}$. across.

On the south side of the College in the back quadrangle stand a Sycamore ( $7 \mathrm{ft} .2$ in.) and a grafted pendulous Lime, Tilia petiolaris (6 ft.), which is always some weeks later than the Common Lime.

The relative position and present size of the trees are fairly well indicated in New's engraving of the College, but the artist's style does not sufficiently discriminate even between the most diverse types of foliage.

The Warden's private garden contains by far the best collection of trees outside the Botanic Garden.

* According to Sir William Schlich this tree is not more than sixty years old, probably less. 
By the liberality and foresight of Warden Wills the ground now covered by the Warden's garden was secured for the benefit of the College and of Oxford as an "open space" in

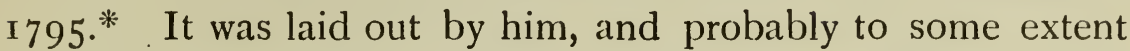
by his successor, Warden Tournay. The present Warden, who has kindly permitted the publication of the following notes on his trees, informs me that there is a tradition that Warden Wills received many rare plants collected and brought to England by his brother, Admiral Wills, from his voyages. The older trees, planted at the end of the eighteenth century and at the beginning of the nineteenth by Wardens Wills and Tournay, include the Tulip Tree, the Judas Tree, and the Medlar.

Trees near the House GIRTH

Tulip Tree . . . . . IO 8

Turkey Oak, Quercus cerris . 52

Californian Red Wood:

Sequoia sempervirens $\quad 37$

Evergreen Oak :

Largest of 4 limbs $\quad$. 55

Diameter of bole, nearly 30

Judas Tree :

Largest of 7 limbs $\quad$. 3 o Araucaria imbricata . $\quad 47$ Evergreen Oak . . . 49

Hollies . . . $\begin{cases}2 & 5 \\ 2 & 2\end{cases}$

Cherry Laurel

North Walk

Lucombe 0ak

Quercus lucombeana
North Walk (cont.)

Elms

Medlar

Scotch Firs

West Walk

Ailanthus ( 8 )

On the Lawn

Pinus excelsa

Weeping Ash

Evergreen 0ak:

2 Limbs (together) . 90

Near the ground . . 8 o

Apple. . . . . 4 o

Abies nordmanniana . . 25

Birch . . . . 53

Pinus excelsa . . . 62

Libocedrus decurrens . . 30

Garrya (bush Io ft. high) . O I I

* The date of the assignment to the College of a lease held by Wills under Merton College of about 4 acres of land lying between the site of Austin Friars and the New Parks. The fee-simple was purchased by Wadham College in $\mathbf{1} 834$. 
On the Laren (cont.)

GrRTh
ft. in.

On the raised Bank

GIRTH

Purple Beech . . . Io 8

Ailanthus ( + ) . . . 88

Silver Fir . . . . I 6

Apple

- $\quad$ I 6

Holly

ft. in.

Pear.

Scotch Fir .

Sequoia gigantea Robinia

. $\quad{ }^{\circ} \mathrm{I} \frac{1}{2}$

Thorn

Lucombe Oak

Walnut

Lawson's Cypress

Spruce

Oak .

Scotch Firs

$\begin{array}{ll}2 & 6\end{array}$

$\begin{array}{ll}3 & 9\end{array}$

$\begin{array}{ll}6 & 4\end{array}$

$\begin{array}{rrr}7 & 5 & 5 \\ . & 5 & 8\end{array}$

. 410

$\begin{array}{ll}9 & 2\end{array}$

$\begin{array}{ll}2 & 3\end{array}$

. 33

Upon the old grey walls grow the Cheddar Pink and the yellow Oxford Ragwort, Senecio squalidus. It will no longer be the Oxford we know and love, when neither Cheddar Pinks

Nor wa'flowers of a yellow dye

Glour dowy o'er her ruins high (R. FERGUSSON);

but so long as Oxford weather and Oolite stone endure, Nature, if only let alone, may be trusted to provide sanctuaries for her floral gems.

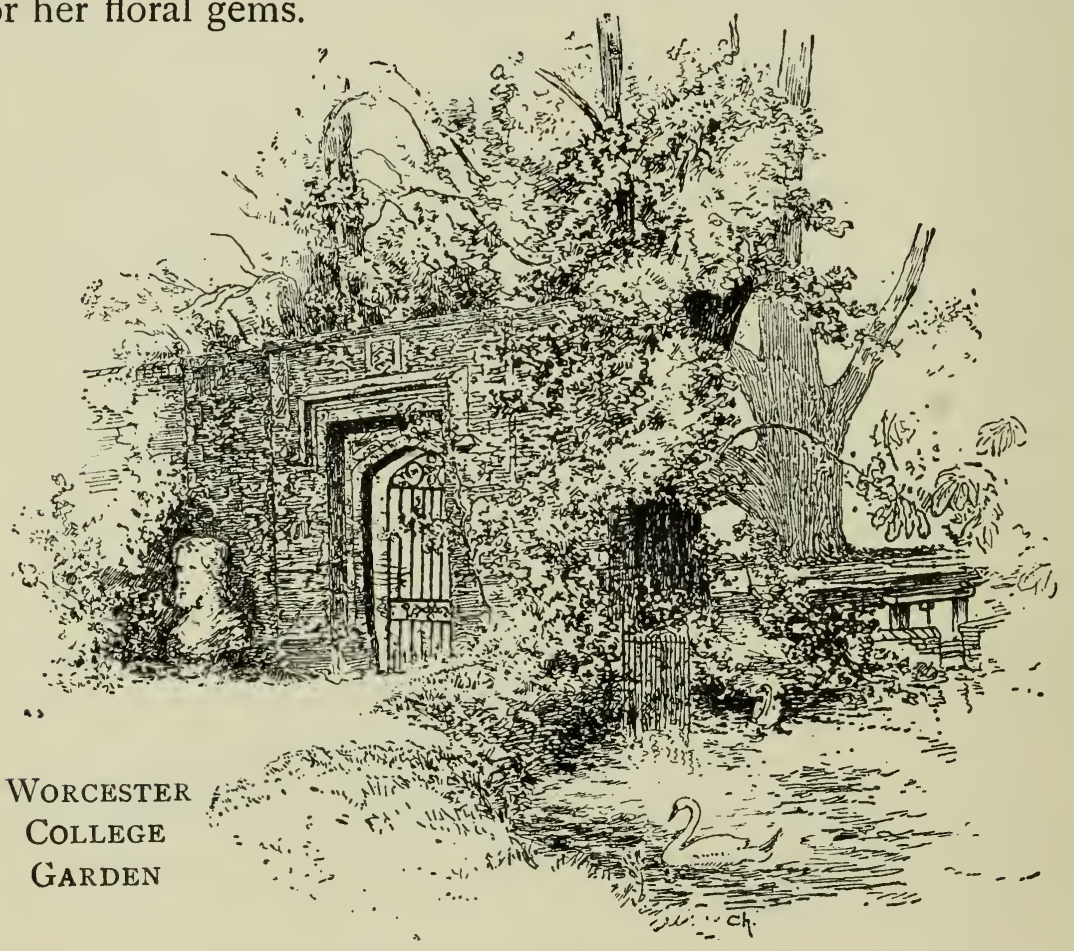




\section{APPENDIX F}

\section{THE PARKS, OR UNIVERSITY PARK}

To a park three things are necessary: r. A grant from the King. 2. Enclosure by pale, wall, or hedge. 3. Beasts of park, such as buck, doe, etc. And where all the deer are destroyed it shall no more be accounted a park.-CRUISE, Digest in N.E.D.

A park in N. Britain is a ground enclosed for pasture or tillage.

A park is the space occupied by the artillery, etc. in an encampment.

Long before the Parks became the property of the University we find references to the public walks on which members of the University and others used to take exercise. The venerable President of Magdalen, Dr. Routh, is said to have compared the air with that of the Highlands of Scotland, and to have talked with a person who had seen Charles II. with his dogs there (F. H. H.). About 1853 , negotiations for the purchase of some or of all the land were opened between the University and Merton College, which resulted in the purchase of the following parcels :

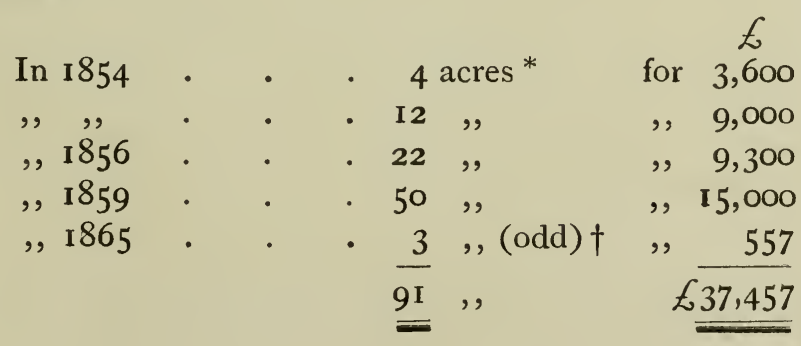

* For the University Museum.

† Including Mesopotamia (2 a. I r. 20 p.). 
On November $18, \mathbf{1} 858$, an acre of land situate to the north of the New Museum was generously given up by the lessee, Mr. Stevens of Holywell ; and the Museum Delegacy (the Curators of the Parks not having then come into existence) were empowered to plant it [Letter of "E. B. P." to the Oxford Magazine, published just fifty years after the date of the surrender of the lease by Mr. Stevens].

According to the "First Report of the Park Delegates," dated June 3, 1863 , the original scheme for the laying out of the ground seems to have been largely due to Mr. J. Bateman, F.R.S., of Magdalen College. Among other things he suggested that twenty-six acres should be planted with Coniferous trees so as to form a Winter Garden, and that the other trees should be chosen so as to produce their most striking effect in spring and autumn. Dr. Daubeny was a member of the Delegacy.

The laying out of the land was still being discussed in January, 1864, and in the following year $£ 500$ for purchasing and planting trees and shrubs was voted by the University.* The oldest plantations in the middle of the Parks date from I 870, while those round the Cricket Pavilion and the Observatory are some ten years younger. The earlier planting was carried out under the supervision of Mr. Hopkins, Fellow of Magdalen, but afterwards Mr. W. H. Baxter, previously at the Botanic Garden, was entrusted with the work, until his death in I89o. Baxter planted the collection of Thorns along the North and West Walks, and drew up a list of trees and shrubs in the Parks, with a view to the replacement of such as had perished since the original planting was done. $\dagger$

* An operation preliminary to the planting of trees was the expulsion of undesirable characters, and was thus described by Riddell in his Proctorial Oration- "Agros expurgavi qui Parks dicuntur."

$\dagger$ The mortality indicated by Baxter's MS. lists of 1888 is so appalling that we shrink from considering it in detail. 
Entering the University Park* at the North-West Lodge, the path leads through a shrubbery, and on the right there may be noticed an example of Cotoneaster montana, one of the larger species of this genus which bears fine clusters of red berries in autumn. Turning to the left, and following the path that runs parallel to the back of Norham Gardens, considerable numbers of Conifers are to be seen, although nothing of special interest. The Weymouth Pines are very much affected by a woolly Aphis which lives upon the bark and brings the tree into an unhealthy condition. There are some good groups of Mountain Pine, a species which is met with towards the upper limits of tree-growth in the mountains of Central and South-Eastern Europe. Of this species, there are a large number of varieties, some of which remain quite dwarf, while others attain to tree-like proportions.

On either side of the path are a number of interesting plants. On the right is the compact-growing Ulmus montana nana, and on the left, Pyrus riviolaris from N. America, and a pendulous Mountain Ash. Further on are a number of Oaks : on the right, an "Italian Oak," as the late President of Trinity always called it, branching near the ground, one limb girthing $3 \mathrm{ft}$. 3 in.; on the left, Quercus fastigiata, $Q$. Ilex var., and standing back, the large-leaved $\mathbf{Q}$. coccinea ( $4 \mathrm{ft} .3$ in.), a specimen of that semi-evergreen Oak known as the Lucombe Oak, which originated as a hybrid in a nursery in Exeter, and lastly, the Cork 0ak, Q. suber ( $3 \mathrm{ft} .9$ in.), between two large Box bushes. On the right is a Sea Buckthorn $q$. A good variety of the pendulous Beech is also to be seen there, and a well-grown example of the Turkish Hazel, of which,

* We are greatly indebted to Professor Somerville, the Secretary to the Curators of the University Park, for the greater part of pages 239-242 on the trees of the Park. A few notes have been added from information supplied by Mr. Mount. For the measurements, the compiler is responsible. 
however, there is a much better specimen in the Botanic Garden. Near by is Acer tartarica. The ground between this path and Norham Gardens appears to be well suited to the growth of trees, as is evidenced by the fine tall specimens of Elms and Lombardy Poplars, the latter no doubt having been planted as nurses, whose removal had been neglected as the better trees grew up. Several varieties of Elms may be seen here, including the fine Camperdown Weeping Elm, girthing $2 \mathrm{ft}$. 7 in., Ulmus glabra pendula, and others. At the point where the path diverges to the left to the exit at the foot of Norham Gardens, there is a fine specimen of Planera Richardi, otherwise known as Zelkova crenata, which at breast-height girths $6 \mathrm{ft}$. $6 \mathrm{in}$. There is, however, a larger specimen of this tree on the south-east side of Christ Church Meadows. Near the same spot, fringing a glade, are specimens of pendulous Limes (Tilia petiolaris pendula, 5 ft. 6 in., T. heterophylla, T. aurea). Growing beside the river are some good trees of the Cut-leaved Alder (Alnus laciniata), while a little further on, in a small, enclosed group, near the point where the river-path diverges from the stream, are some healthy trees, about twenty or thirty years old, of the deciduous conifer, Taxodium distichum, which is characterised by shedding its young shoots annually with the leaves attached. The underwood of this clump consists of Dogwood, whose fine red twigs glow warmly on a bright winter day. A fifteenyear-old Cormus florida rubra is growing at the north end of the clump. Going westwards, towards the Superintendent's Lodge, there is a large Populus abele acerifolia, $9 \mathrm{ft}$., in the border; and a healthy young specimen of Abies grandis, $2 \mathrm{ft}$. in girth, will be seen close to the end of the shrubbery. This is a species which has received much attention lately from British planters, because it is found to be more resistant to the attack of an Aphis which is peculiar to Silver Firs, and most destructive to most species. 
Close to the South-East Lodge are three old Elms * of the English variety, and growing alongside are younger representatives of the more upright-growing form that is known as the Cornish Elm. The trunk of one of the old Elms was seared from top to bottom by lightning (circ. 1903); pieces of the bark were blown 50 yds. away by the force of the explosion, and persons near by suffered severely from shock. From the lodge, westwards, there runs the Lime avenue, consisting for the most part of ordinary Lime-trees, circ. $3 \mathrm{ft}$., but the sixth tree in the row, counting from the lower end, is a Silver Lime, Tilia argentea, $4 \mathrm{ft} .9$ in., a native of S.E. Europe. On the left-hand side, and just within the

* I am indebted to Dr. Dixey of Wadham for the following story about these Elms :

The old Elms near the Lodge at the end of the South Parks Road were once more numerous than they are now. The furthermost tree in the row was the subject of a story about Ben Symons, Warden of Wadham [183I-7I], who, being upon one occasion the only Curator of the Parks in residence in the Vacation, had it cut down, sold the timber, and (as was libellously asserted) pocketed the proceeds.

When his colleagues who had reassembled for term, discovered what had been done, and had nursed their righteous indignation up to the point of bearding the Warden himself, they wrote, asking for an interview. On entering his presence, they were received with a short but forcible address to the effect that while they had been enjoying their holiday, gallivanting about the country, he, the Warden, had been assiduously minding the duties of their Curatorship in Oxford. When the first spokesman had opened at length upon the enormity which had been perpetrated (to which the Warden only replied, "Yeth, yeth, yeth"), No. 2 spoke, requesting an explanation of what he meant by it, only to receive the same answer, "Yeth, yeth, yeth. Has any other gentleman anything elth to thay?" whereupon, No. 3, and then, after the same answer from the Warden, the others poured forth their grievance.

Then, when no further response come to his "Yeth, yeth, yeth. Has any other gentleman anything elth to thay?" the only answer he gave was, "Well, gentlemen, you may talk, and you may talk, and you may talk, but you cannot put back that tree!" and he bowed them out of the room. 
entrance, is a fine Table Yew, $28 \mathrm{ft}$. across, and further, over a yellow-berried Yew, is a Spanish Chestnut, $5 \mathrm{ft}$. 6 in. in girth, and probably the largest in Oxford, for it does not do well in our lime-sodden soils. Further on, and just as one would emerge from the Park at the exit at the west end of South Parks Road, is a well-grown specimen of Chamaecyparis nootkaensis, $2 \mathrm{ft} .3 \mathrm{in}$, otherwise known as Thujopsis borealis, one of the most decorative of the British Columbian Conifers, and one which has proved thoroughly hardy in this country. In British Columbia it attains to a large size and is not an unimportant timber tree.

Retracing our steps from the gate, we skirt the back of the Physiological Laboratory, and along this path are to be seen specimens of Araucaria imbricata, $2 \mathrm{ft}$., the so-called Monkey-puzzle Conifer of Chili, good specimens of Cedrus atlantica, $4 \mathrm{ft} .3$ in., and two Cedrus deodara, $2 \mathrm{ft} .6$ in. (one is $C$. deodara, var. robusta), the former being a native of Mount Atlas in N. Africa, while the latter is an important tree in the Himalayas. A Spanish Chestnut in the same clump girths $4 \mathrm{ft}$. Alongside the path also there are specimens of Pinus cembra, one of our native European trees, met with, along with the Mountain Pine, in high altitudes in Switzerland, the Tyrol, and the Ural Mountains, spreading eastwards through Siberia. On the side of this plantation, towards the lawn-tennis ground, is a specimen of the tree called in N. America the "Tamarack," Larix microcarpa, 2 ft. 7 in., a Larch which is distributed all over Eastern Canada and far south in the Eastern United States. It is characterised by having very much smaller cones than the European Larch, nor does the bole ever attain to such large dimensions. Near the inner border of the shrubbery is a young Cut-leaved Beech. The isolated clump to the west of the Observatory is known as Daubeny's Clump, because he planted the two Sycamores, now girthing $3 \mathrm{ft}$. 6 in., which are growing in the middle of a group of Horse-chestnuts. 
Passing the exit gate opposite Keble Road, we observe on the right a double Horse-chestnut, $7 \mathrm{ft}$., and a Cladrastis, and on the left a large variety of Thorns, which are now being somewhat interfered with in growth by the more robustgrowing Lime-trees situated alongside. On the right-hand side of this path there are Cytisus quercifolia, Tilia alba, $6 \mathrm{ft} .2$ in., and two specimens of the American Paper Birch, Betula papyrifera, I ft. 9 in., a N. American species, whose bark, of a very silvery character, can be used for writingtablets, and which in N. America has been employed by the Indians in the making of canoes. There is also growing along this path a specimen of Sophora japonica, $4 \mathrm{ft}$. I I in., a leguminous tree indigenous in Japan, which in this country grows well. The fine example in the Botanic Garden has already been mentioned on p. 39 .

\section{Mesopotamia}

The older trees in Mesopotamia are for the most part pollarded Willows, which, not having been cut for a great number of years, have grown great crowns of boughs stretching out in winter like the arms of some gigantic cuttle-fish which

Winnow with giant arms the slumbering green;

but in summer they form an avenue of Willow-trees of rare character and beauty. The University owes this fine feature largely to the taste and persistence of $\mathrm{Mr}$. Raper of Trinity, who on one occasion, the Curators of the Parks being equally divided for and against pollarding, saved the boughs by inducing the then Vice-Chancellor to examine the Willows himself before giving his casting vote. The Vice-Chancellor saw that the "branches of the Willows had for the most part a separate tap-root running down deep where there is plenty of moisture, which a Willow loves, and so holding the tree up "- and voted against the pollarding. Few people in Oxford have thought more about this question than Mr. Raper, and therefore it is worth while to put his opinion on record, 
"that the cutting of large branches of the Willows weakens a proportionate amount of root, and renders the tree more liable to fall (witness the number of pollarded trees that have fallen on the Merton side of the lower Cherwell). There is an exact correlation between branch and root: injury to branch means corresponding injury to root. . . . This is a most beautiful avenue in the summer; and it would be entirely spoiled for thirty or forty years by being pollarded now. Therefore I think it better that the present generation should have the advantage of the Willows for as long as they last, and then plant new ones, which would be far better than to pollard the old ones now, with a prospect of desolation for a long time. They have been threatened since, but still survive."

The heads of some of these old pollards measure $6 \mathrm{ft}$. across. On many of them has accumulated a quantity of vegetable imould, in which the seeds of Thorns, Brambles, and a variety of other plants have germinated, and the young plants have driven their roots into the rotten heart-wood of the Willows. A list of such epiphytes is given on p. 253. In like situations it might be possible to grow Rhododendrons and other similar plants which will not flourish in the Oxford soil. Two large Pcplars ( $\mathrm{o} \circ \mathrm{ft}$.) grow on either side of the Middle Lasher.

LIST OF SUPERINTENDENTS OF THE UNIVERSITY PARK

W. H. Baxter

. ? I $887-1890$

J. Ellam * . . . . $1890-1892$

H. Mount . . . . . $1892-$

REFERENCES TO ARTICLES IN THE "OXFORD MAGAZINE" ON THE PARKS

I906, Dec. 5. Poynton, A. B., University Parks. [Letter respecting children and their games.]

I 908, June 4. W. W. F. Bird-Life in the Parks: Past and Present.

" June II. Balfour, H. , ", , [A letter.]

" Oct. 22. E. B. P. The Museum and the Parks. A Neglected Chapter. [Followed by seven controversial letters by F. H. H., C. L. S., and E. B. P.] 


\section{APPENDIX G \\ OTHER NOTEWORTHY TREES}

In the seventeenth century "in most other parts of the city it was gardens, gardens all the way, with grey old houses and walls between. No slate and bricks disfigured the approaches ; Bullingdon Heath stretched unbroken, but for a few cottages, up to Magdalen Bridge. The old walls were still intact.-FLETCHER, History of England.

Better the madness of a Shenstone planting trees than that of others, Hercules-like, tearing them up by the roots.-Gilfillan, Life of Shenstone.

\section{RAdCliffe OBSERVATORY}

The Radcliffe Observer, Mr. A. A. Rambaut, with his customary courtesy, has supplied me with the following list of trees and their measurements, and notes that the heights may be accepted to within $\pm \mathrm{ro} \mathrm{ft}$.

One of the oldest trees is the Mulberry, girth $7 \mathrm{ft}$., which is shown in Hornsby's plan of the Garden in 1772.

Beeches :
I. Opposite Hall Door
2.)
3. In a clump near the Infirmary

$50-60 \quad \begin{cases}8 & 4 \\ 7 & 8 \\ 8 & 5 \\ 8 & 7\end{cases}$

Elms : $\mathrm{ft}$. $\mathrm{ft}$. in.

Approx. Height Girth at 4 Ft

I. Behind Stable . . . . $\quad 65 \quad 62$

2. On the Drive . . . . . $\quad 75^{-80}$ Io 0

3. , , . . . . . . $\quad 100 \quad 12 \quad 4$

4. Behind Infirmary Chapel . . 60 I I I

5. Topped by Stone in 1887 because $\} \quad\left\{\begin{array}{l}\text { I I I I } \\ \text { 6. }\end{array}\right.$

7. $\}$ they interfered with observations $\}- \begin{cases}\text { I } 4 & \text { I } \\ \text { I } 5 & 3\end{cases}$

Cedars :
Spanish Chestnuts:
30
$9 \quad 8$
$\begin{array}{ll}7 & 9\end{array}$
I.
6 II
2. 


\section{The High Street}

Between St. Mary's and Magdalen Bridge were formerly many small picturesque gabled houses and almost every one had its little garden. But owing to the extension of the College and University buildings, and to the growth of the sordid spirit of commercialism, the amenities of the High as a residential street and the number of trees growing there have both diminished. A beautiful tree is of less commercial value to a shopkeeper than a shanty in a back-yard. Time was, when an impressionist described Oxford as rising "from groves which hide all buildings but such as are consecrated to some wise and holy purpose" ; but the continued depopulation of the centre of the city and the spreading of the "ugly, irrelevant suburbs," by St. John's and other Colleges has, in a very few years, changed the city for the worse.

An instance of this kind of perversion occurred only a few years ago, when the charming and unique old-world garden of the Principal of St. Edmund's Hall, reaching along the backs of the High Street houses, between grey stone walls to where the old city wall * peeped out between wreaths of ivy, was sacrificed, together with the gardens of several houses adjoining, to the erection of a great schola orgiorum, horrid to look upon from without, and dubious from within. An even more remarkable sign of the times is that it is held in some quarters that those should be held in highest honour

* This large piece of the fine old city wall was pulled down by a College that, only a few years previously, had by its agents wantonly demolished another and longer piece at the back of some unnecessary and badly-planned houses in King Street. Such a deplorable act of vandalism has been excused by Mr. C. R. L. Fletcher in 1907 as follows: "Even while I write, I learn that the Bursar of one of the leading colleges has ordered the destruction of a piece of the old city wall ; when remonstrated with, he replied : $i$. that it was a very old wall ; ii. that it was very much in the way ; iii. that there was plenty of it left." I am indebted to G. E. B. for the reference to this note to Fletcher's " History of England," vol. ii. p. 378 . 
who most embody the modern spirit of rapacity, and who, by doing the greatest violence to the beauties of nature and of antiquity, contrive to extort the highest rent from their square inches of land.

In the High Street there still remains one tree, the Sycamore between Nos. 32 and 33, to remind us of the old days and to help in the "dramatic effectiveness" with which some of the fine buildings are successively brought into view as one follows the curve of the street.* The present girth of the tree is close on $7 \mathrm{ft}$.

A tree opposite was cut down to make room for a domelike excrescence, which some, trusting the architect, believed would be invisible from the High Street.

The Elms along the old Gravel Walk by Magdalen College are gradually becoming fewer in number and are not being replaced. On the south side a large Robinia was removed from No. 6r only a few years ago. With it went one of the most beautiful decorative effects in Oxford, for the branches of the tree stretched out under an electric lamp in the street, and at night the interlacing shadows of the elegant pinnate leaves of the Robinia produced an exquisite pattern, which I have seen approached only in Japanese decorative art.

One of the largest Pear-trees in Oxford is growing in the garden of the Old Bank. Its present girth is $5 \mathrm{ft} .9$ in.

\section{SPIRe of St. Mary's Church}

An Elder, Sambuius niger, used to grow above the north turret (Druce, 1886). Perhaps the plant now living in the churchyard may be a near relation. A cormorant was killed from the steeple in 1675 (R. Plot).

\section{HOLYWELL}

Behind Holywell Cottage two fine trees stand on the north side of Love Lane (now Jowett Walk). One, a Robinia, second only to the large tree at Exeter College, measures Io ft. 4 in. The other, an old Mulberry, girths $6 \mathrm{ft} .8 \mathrm{in}$. at about $2 \mathrm{ft}$. from the ground. I 889 .

* Cf. T. G. Jackson, "The High Street," "Magazine of Art," Aug., 


\section{StT. Giles'}

At the Judge's Lodgings, No. I8, the largest Horse-chestnut measures $8 \mathrm{ft} .8 \mathrm{in}$., and the Robinia on the lawn $9 \mathrm{ft} .4 \mathrm{in}$. at the ground, but only $6 \mathrm{ft}$. Io in. round the surviving $\operatorname{limb}$, measured just above the point of bifurcation.

A grafted Purple Beech at No. 20 girths $5 \mathrm{ft} .6$ in. just below the graft.

A fine old Mulberry, $7 \mathrm{ft} .2 \mathrm{in}$. in girth, is living in the garden of No. 37 ( $J$. B.).

\section{Magdalen College School}

Tilia petiolaris pendula, $8 \mathrm{ft} .3$ in.

at the graft.

Weeping Willow, $7 \mathrm{ft} .4$ in.
Weeping Beech, $5 \mathrm{ft} .3$ in.

Robinia, $9 \mathrm{ft}$.

," $5 \mathrm{ft} .2 \mathrm{in}$.

ST. Hilda's

The largest Lilac in Oxford used to grow in the garden (Mrs. Barclay).

\section{GRANDPONT HOUSE}

2 Robinias, $8 \mathrm{ft}$., $7 \mathrm{ft} .7$ in.

3 Apple-trees, $4 \mathrm{ft} .7$ in., $4 \mathrm{ft} .4$ in., $4 \mathrm{ft} .3$ in.

Arbor Vitae, 2 ft. 4 in.

Birch, $5 \mathrm{ft}$.

Evergreen Oak, $8 \mathrm{ft} .8$ in. at the ground.

Evergreen Oak, split open, measured $2 \mathrm{ft} .7 \mathrm{in}$. in diameter.
Holly, $2 \mathrm{ft}$.

Judas Tree, $2 \mathrm{ft}$. in girth and $20 \mathrm{ft}$. in height. A limb which was cut off a few years ago measured I ft. 2 in. in diameter.

Mulberry, $5 \mathrm{ft} .4$ in.

Turkey Oak, 6 ft. 2 in.

\section{UPPER RIVER}

The stump of a large Poplar on the towing-path not far from the railway station has a girth of $13 \mathrm{ft} .2$ in.

\section{IFFLEY CHURCH}

The bole of the old Yew measures about $6 \mathrm{ft}$. by $4 \frac{1}{2} \mathrm{ft}$. through. There is a view of it in Mackenzie's engraving of the Church from the south-west. The other large trees near, are a Cedar and a Tulip Tree in the Vicarage Garden.

\section{Headington Hill}

Jo. Pullen's Elm : “On Friday last (Oct. 29) were planted four yew trees upon the top of Heddington Hill, round the elm tree which is commonly called Jo. Pullen's tree. They are given by Mr. Tilman Bobart, brother of the lat Mr. Jacob Bobart " ("Reliquiae Hearnianae," I 725). 
The Rev. Josias Pullen was Vice-Principal of Magdalen Hall, and died I 714. His tree is depicted in Ingram's "Memorials," "St. Clement's," p. I6. The footpath leading up the front of Headington Hill * was made by general subscription in I740. "It used to be said of the Rev. Jo. Pullen, when he planted the elm-tree, that he had made a way [away] with the public money. It was under the shelter of this same tree, ulmi sub tegmine grati, that Canon Holmes, when going shooting in Stanton Woods, would put off the canonicals in which he had walked out of Christ

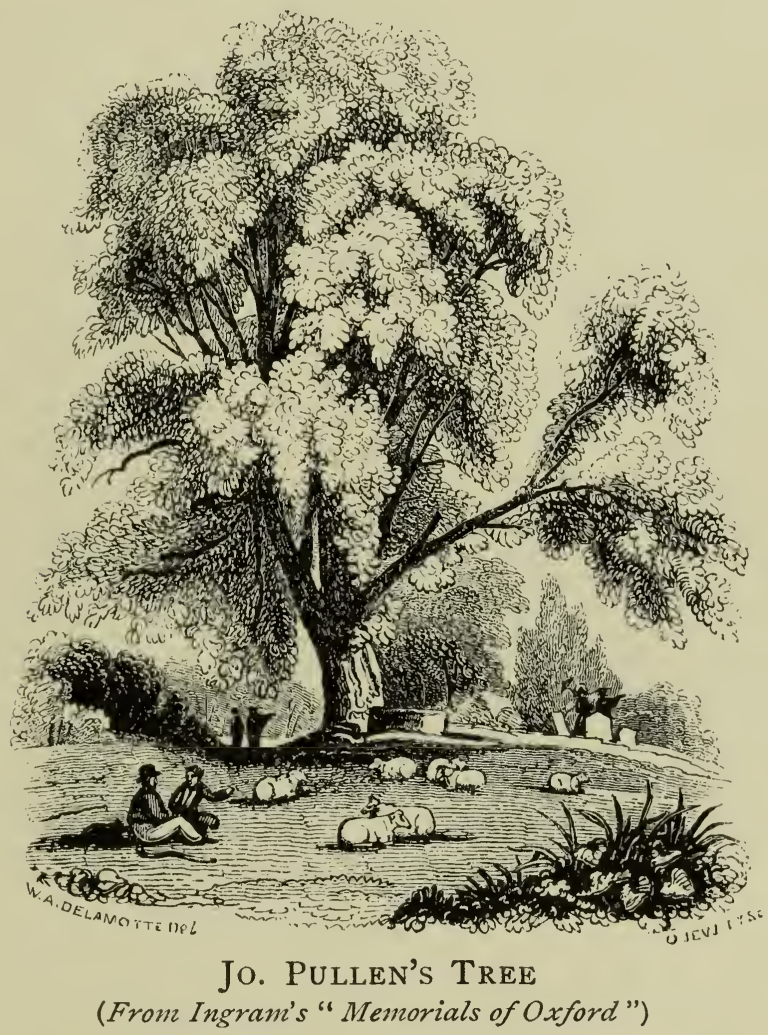

Church and up Headington Hill, and, with his shooting clothes now fully revealed, take gun, hat, and dog from a servant in waiting and trudge on to the forest" (Cox).

The Elm was presented informally by Mr. Whorwood of Headington House to the University. In 1856 its condition was described as mutilated.

* The pretty winding path up the back of the hill is said to have been planned by Dr. Tournay, Warden of Wadham (I806-3I), when he held the office of "Curator of the Public Walks" (Cox). 


\section{Headington Hill Hall}

Several of the fine trees above the terrace were planted by Baxter about 1859 or 1860 . A list, printed by him, is said to have been prepared, but I have not been able to see a copy.

\section{OXFORD STREETS}

The following list of roads along which trees have been planted during the last few years, with the approximate dates of the planting, has been drawn up by Mr. W. H. White, the City Engineer, who takes so deep an interest in all that affects the beauty and welfare of our city.

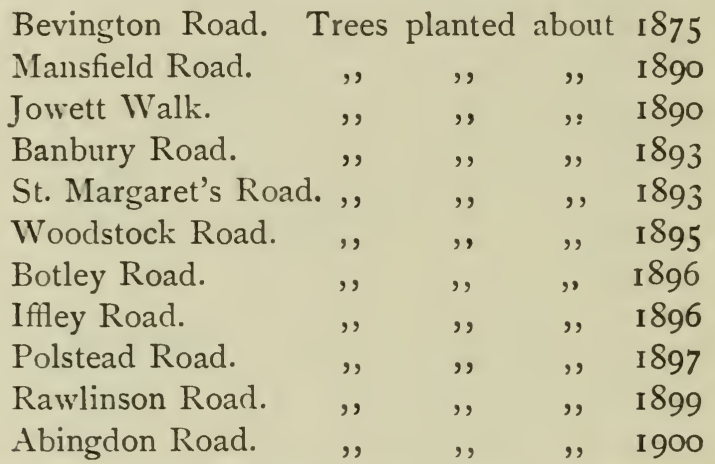

In many cases later plantings have been made because some of the trees first planted did not flourish, and others were killed by coal-gas leaking into the soil from the gas-mains.

The Planes in St. Giles', for instance, have been planted at different periods during the last forty years. 


\section{APPENDIX H}

\section{WILD GARDENS}

\section{The Ruskin Reserve at Cothill}

In 1902, by the generosity of Mr. Henry Willett, the Ashmolean Natural History Society of Oxfordshire became the possessors of about $\mathbf{I} \frac{3}{4}$ acres of marsh, water, and woodland, to be kept untouched as a reserve for the wild animals, birds, and plants which are being slowly " civilised" out of existence. Another couple of acres were added in 1904, to be used for the same purpose. It is a charmingly secluded spot, and its botanical treasures have been described by Mr. Druce in the Society's Report for 1902 .

\section{Johnson's Piece on Sho'tover Hill}

On November 6, 1908, a meeting, representative of some I 40 subscribers, held in All Souls College, passed the following resolution: "That the plot of land of some thirty acres in extent lying immediately to the south-west of Shotover Plain be handed over to the Chancellor, Masters, and Scholars of the University of Oxford, on condition that, while retaining the ownership of the same, the University shall devote the use thereof to the public, with the exception of one day in each year, and shall entrust the charge of the plot to the Curators of the Parks."

A plan was published in the Oxford Magazine for November 12, 1908. 
It is with great pleasure that we record the existence of these two properties, to be preserved, the first as a wild garden in which indigenous plants and animals may find a temporary refuge from their arch-enemy, man; the second for the use of the public. To us in Oxford they are invaluable objectlessons at a time when every form of pressure is being put upon all land-owning Colleges and landlords to cover their estates with bricks and mortar.

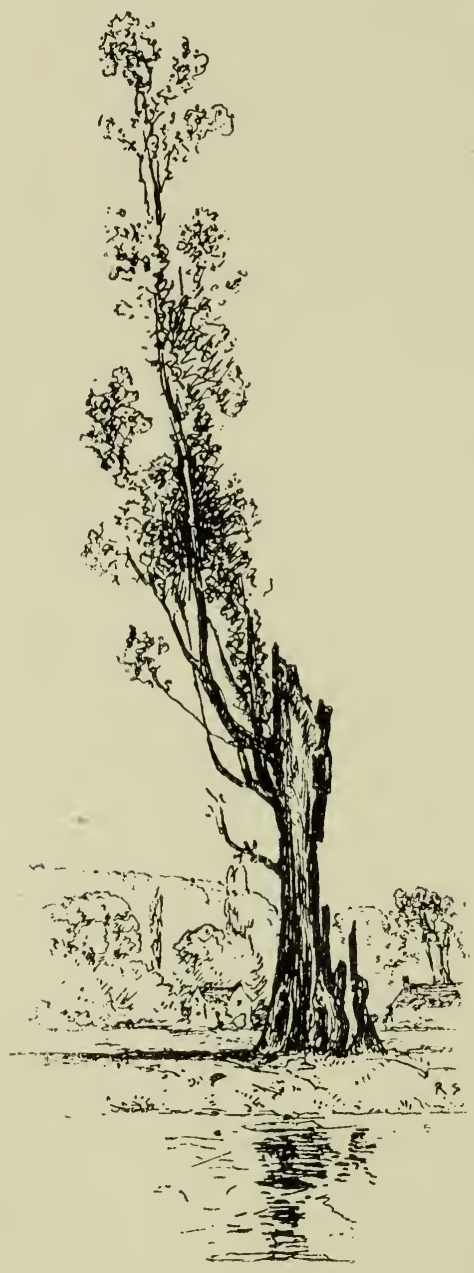




\section{APPENDIX I}

\section{THE GARDENS OF THE WINDS AND THE BIRDS IN MESOPOTAMIA}

For the benefit of those who do not know Oxford, it may be stated that the "between the rivers" is between the King's Mill Stream and the main channel of the River Cherwell.

As an undergraduate I was much struck by the number, size, and variety of the plants which grew on the pollarded Willows of the Parks and Mesopotamia, from seeds conveyed thither by wind or by birds, and, thinking that it might be of interest to ascertain to what extent these " epiphytes" persisted upon the same Willow from year to year, to what age they might live, and by what circumstances their life in so precarious a position might be affected, I commenced a record; but have, alas, not kept it up as assiduously as I should.

The plants noted were those living upon the Willows growing along the King's Mill Stream on the east side of the Mesopotamia walk. They are numbered consecutively from the Mill to the Rollers below Parson's Pleasure.

Plants with names printed in black type have survived for 20 years.

" ", " $" \begin{gathered}\text { italics } \\ \text { ondinary type occasion in the } 4 \text { selected years. }\end{gathered}$

o signifies no epiphytic flora; $\dagger$, dead Willow.

Plants noted in the Years

\begin{tabular}{|c|c|c|c|c|}
\hline $\begin{array}{l}\text { No. of } \\
\text { Willow. }\end{array}$ & I 888 & I 890 & I900 & I9I I \\
\hline I. & o & o & o & 0 \\
\hline 2. & o & Dandelion & .. & o \\
\hline 3. & o & Comfrey & .. & $\dagger$ \\
\hline 4. & Thorn & $\begin{array}{c}\text { Chickweed } \\
\text { Co }\end{array}$ & . & $\cdot$ \\
\hline 5 . & $I v y, 2$ & Thorn, Currant & .. & + \\
\hline
\end{tabular}



No. of
Willow. 888
6. 0
7. Grass, Thom
8. Currant

Gap with 3 young trees.

9. $0 \quad 0$

Io. o Stinging Nettle

II. Thorn, Dandelion, Comfrey, Currant Chickweed, Nightshade

I2. Dandelion, Gooseberry, Raspberry Thorn seedling, Willow Herb

I3. 0 $\mathrm{o}$

14. Grass, Willow Herb, Dock, Raspberry Nightshade

I5. O O

16. Dandelion, Ivy, Nightshade

Grass, Willow Herb

17. Rose, Willow Herb, Raspberry, Thom, Chickweed Hawkweed, Lamium

1900 I9I I

$\dagger$

.

$+$

$+$

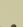

Nightshade

o

$\dagger$

$\dagger$

-

Rose

$\dagger$

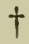

o

o

Thorn

Dead Thorn

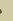

o

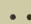

Grass

I8. Willow Herb, Chickweed, Thorn .. Comfrey

19. Grass

20. Grass, Chickweed

Nightshade

2I. O Thorn, Dandelion, Raspberry ..

22. Chickweed, Celandine, Hedge Parsley

23. Thorn, Chickweed, Ivy, Willow Herb

24. Grass

25. Rose

Chickweed, Elder

26. Elder

27. Ivy, Willow Herb

Bridge to Trinity Cricket Field.

28. Grass

Thorn

29. 0

30. Thorn, Chickweed, Comfrey

31. Chickweed, Rose, Thorn

Blackberry

32. Hawkweed, Grass, Raspberry, Thorn

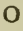

o o

o o

(n)

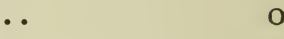
veed 
No. of 1888

33. $\mathrm{o}$

34. $\mathrm{o}$

35. Grass, Chickweed

Lasher.
36. Grass

37. Thorn

38. o

39. Dandelion, Chickweed Seat.

40. Thorn

41. Rose seedling

42. $\mathrm{O}$ Nightshade

43. Rose

Blackberry

44. Dandelion, Thorn
I890

I 900

I9I I

o

Chickweed

o

..

Elder, Chickweed

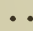

Dandelion

Blackberry, Rose, Nightshade ..

Two young trees.

45. Willow Herb, Thorn, Grass, Chickweed Nightshade

46. Rose, Thorn

47. O

48. Grass, Thorn, Chickweed

Dock, Grass

Nightshade

Seat.

49. O

50. Rose, Chickweed, Grass

5I. Grass, Thorn

52. Rose, Thorn

53. Dandelion

54. Rose, Thorn

55. Rose, Thorn

56. Ivy, Thorn

57. $\mathrm{O}$

58. $\mathrm{o}$

59. Ivy, Thorn, Dandelion, Grass

6o. Thorn, Chickweed

6I. Rose

62. Thorn, Grass

63. Chickweed, Grass, Thorn

64. Thorn, Grass

65. Grass, Dandelion

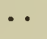

.

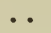

.

-

o

0

Chickweed, Hawkweed

Chickweed

Chickweed

Blackberry

Grass

Blackberry

o

o Grass, Nightshade

o

o

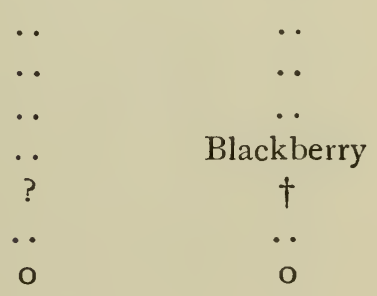




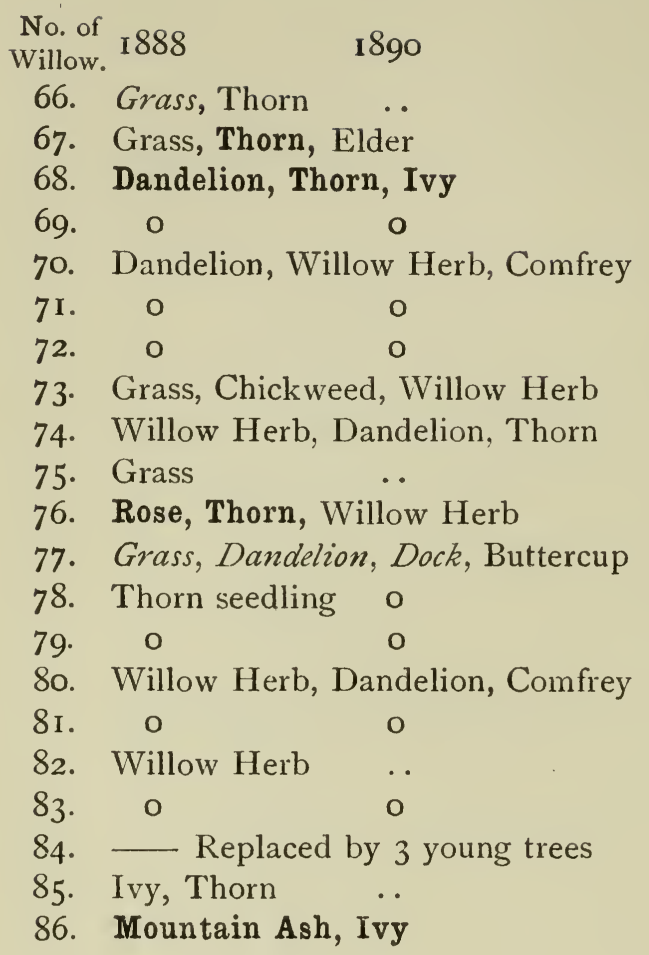

87. o 0

88. Mountain Ash, Chickweed

Ferry.

89. - Replaced by 5 young trees

9o. Grass, Elder, Ivy

Seat.

Three young trees, not pollarded.

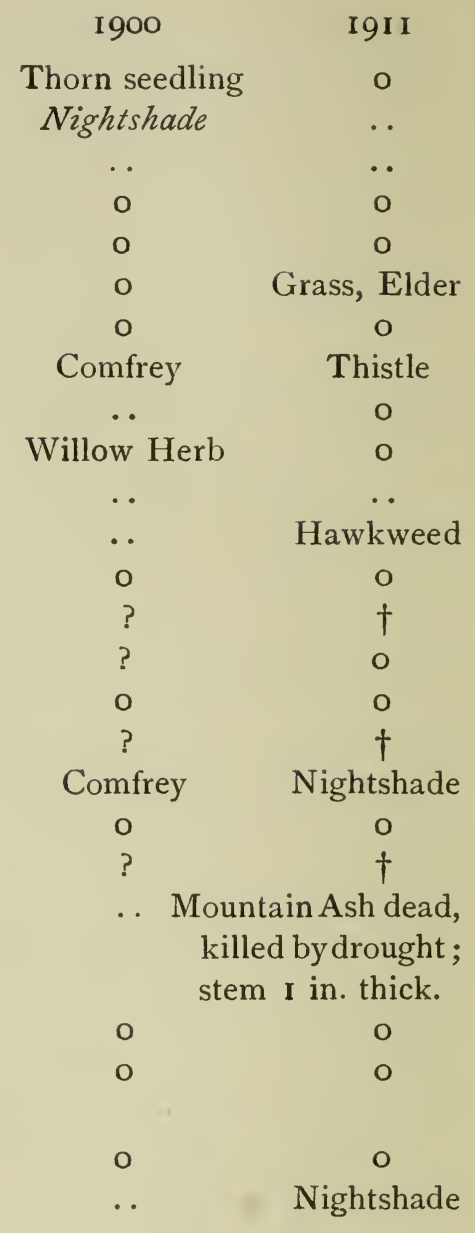
killed bydrought; stem I in. thick.

o

o

o

o
o
.. Nightshade
Comfrey
o
Grass
Nightshade Thorn, Rose
Thorn

Nightshade, Currant seedling o

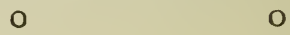

o 


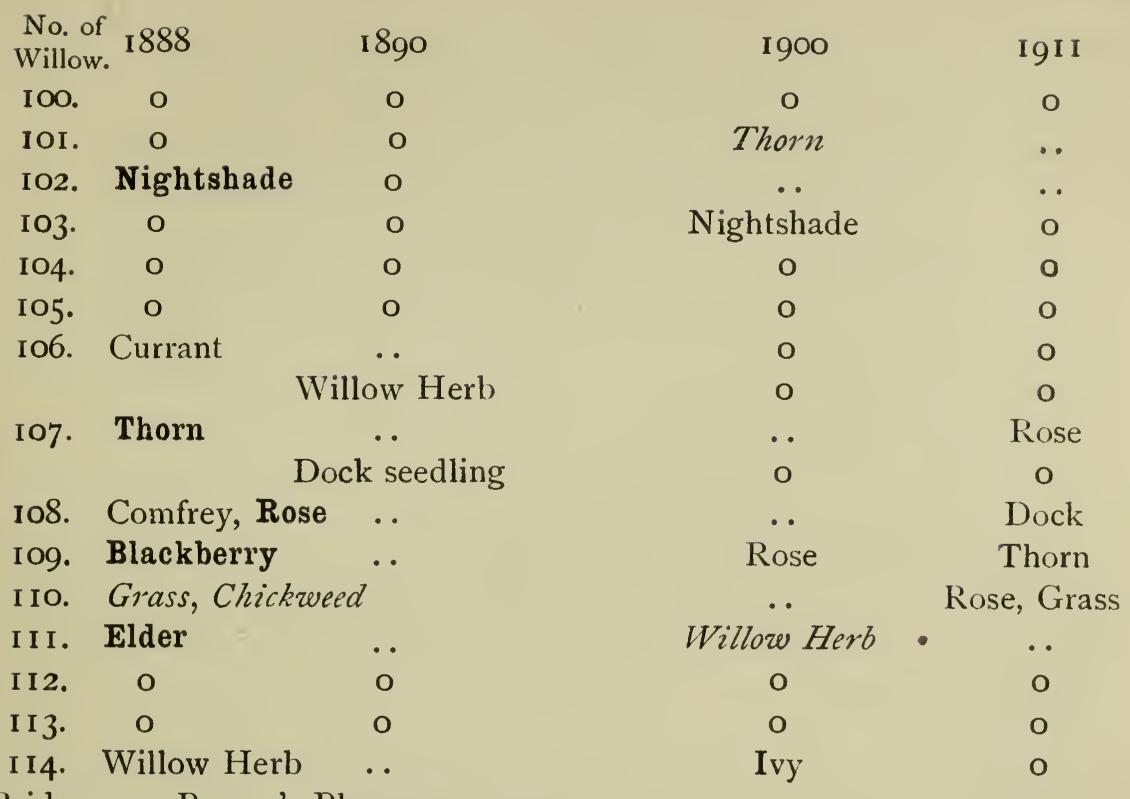

Bridge near Parson's Pleasure.

TOTAL NUMBER OF EPIPHYTES RECORDED IN THE YEARS I 888 and I 890 183 1900 138 IgI I 90

This marked impoverishment in the flora of the Willowgardens has not been wholly due to the reduction in the total number of suitable Willows. Depredations by visitors have been frequent, and so have cases of arson, especially during the abnormal drought in the summer of I9I I, which not only caused the death of many of the older plants, e.g. of the large Mountain Ash, but also of many seedlings, and hindered the germination of seeds.

The surveys of the Willow-gardens were made in all cases at the end of the Long Vacation or at the beginning of the October term, and greater attention was paid to well-established perennials than to the seedlings of annuals which could not be expected to endure. Had the census been taken earlier in the season, many more species would undoubtedly have 
been recorded, as, for example, in the May list printed below, but our interest chiefly centred in the hard-wooded shrubs and trees growing as epiphytes.

Of the Willows themselves, about 14 per cent. have perished in the twenty years. And if it be assumed that out of the I 4 trees some 14 were unsuited for the growth of epiphytic plants, and could not have supported a Willow-garden, the numbers given in the following table may be taken as approximate percentages. It must be remembered that the plants were not under continuous observation, and that the results are based upon the state of things as observed upon four occasions in the autumn; they are, however, sufficiently striking to be worth recording, if only as a suggestion for further research.

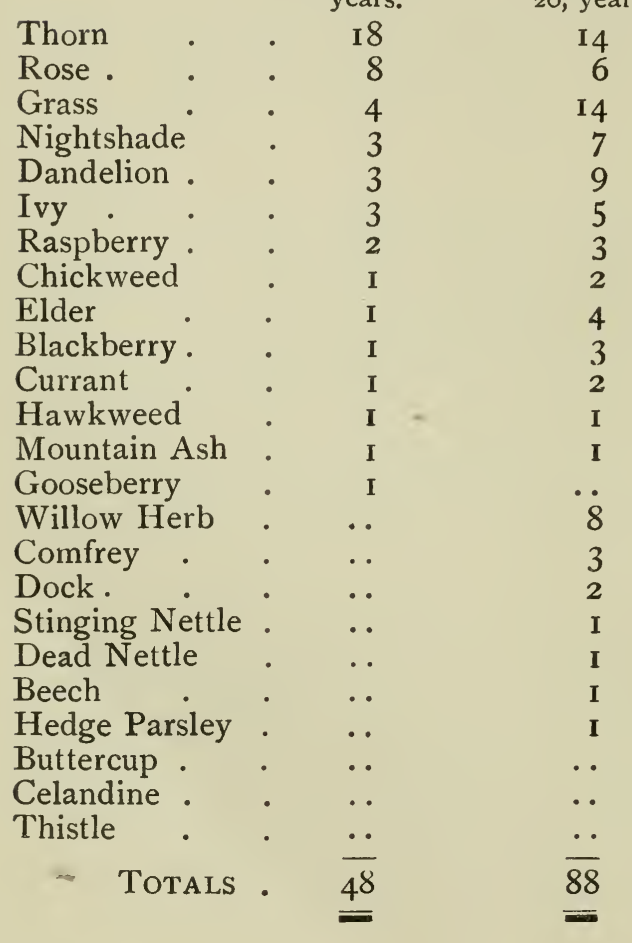

Total number of Willow - gardens in which the plant was noted. Io years.

I 2

6

44

20

36

I7

I8

IO

5
26 
A more complete list of the plants living upon the Willows of the Parks, as well as upon those of Mesopotamia, on May 28, 1906, was compiled by the members of the Ashmolean Natural History Society of Oxfordshire:

Acer pseudo-platanus

Anthriscus sylvestris

Betula alba

Bromus mollis

,, sterilis

Bursa pastoris

Carduus crispus

Caucalis anthriscus

Cerastium viscosum

,, vulgatum

Cnicus arvensis

" palustris

Crataegus oxyacantha

Dactylis glomerata

Epilobium montanum

Festuca rubra

Galium Aparine

Geranium Robertianum

Geum urbanum
Hedera helix

Hieracium sciaphilum

Holcus lanatus

Humulus lupulus

Lactuca muralis

Lamium album

, purpureum

Lapsana vulgaris

Leontodon autumnalis

Lychnis Flos-cuculi

Myosotis arvensis

Nepeta Glechoma

Plantago lanceolata

Poa annua

", pratensis

Polypodium vulgare

Potentilla reptans

Pyrus Aucuparia

Rhamnus catharticus

Total, 57 species.
Ribes Grossularia

" rubrum

Rosa canina

Rubus rusticanus

Rumex Acetosa

" crispus

" obtusifolius

Sambucus nigra

Senecio vulgaris

Sisymbrium Alliaria

Solanum Dulcamara

Sonchus asper $\because \quad$ oleraceus

Stachys sylvatica

Stellaria graminea

, media

Taraxacum officinale

Taxus baccata

Urtica dioica

But to these we can add Fagus sylvatica, Ranunculus ficaria, and $R$. acris. 


\section{ADDENDA}

Addendum to p. I42.

\section{IVORMS}

The Rev. Hilderic Friend has informed me that the following Earthworms have been identified by him among worms collected on March I, I904, and on October 8, I909, respectively. He adds, in a letter, that the Garden has been very imperfectly worked, but has, nevertheless, yielded two forms as yet unknown elsewhere. The list will appear in the "Zoologist" in an article on the distribution of British Annelids.

Lumbricus rubellus, Hoffmeister. ${ }^{*} \dagger$

, terrestris, Linn. ${ }^{*} \dagger$

, castaneus, Sav. $\dagger$

Allolobophora longa, Ude.* $\dagger$

" caliginosa, Sav., forma trapezoides, Dugès. $\dagger$

, intermedia, Friend. $\dagger$

At present only known from this locality. Described and figured in Gardener's' Chronicle, November 27, 1909 .

Eisenia foetida, Sav.* $†$
Eisenia veneta, Rosa :

(I) Var. tepidaria, Friend.* $\dagger \ddagger$ At present only known from this locality.

(2) Var. unnamed.

Eisenia rosea, Sav. $\dagger$

Aporrectodea chlorotica, Sav. ${ }^{*} \dagger$

Octolasium lacteum, Oerley.* $\dagger$

,, cyaneum, Sav. $\dagger \ddagger$

Dendrobaena subrubicunda, Eisen. $\dagger$

Allurus tetraedrus, Sav. $\dagger$

Fridericia sp. $\dagger$ (perhaps striata).

Perichaeta sp. $\dagger$

* Collected March I, I904.

$\dagger$ Collected October 8, I909.

‡ Described and figured in Gardeners' Chronicle, March 12, I904.

Addendum to List of Works, p. I83.

Sloane MS. 1038 in the British Museum :

Catalogus plantarum horti Oxoniensis pariterque earum quae in pagis, silvis, pratis montosisque in Oxonia locis, nascuntur, fols. I-89. 


\section{N D E X I}

\section{THE OXFORD BOTANIC GARDEN}

Abietinae, 87

Abir powder, 107

Abutilon, 97

Acacia, 66, 96, II 7, 123

-

- Locust, 44

Acanthaceae, 76

Acer, 47, 5 I

Acerineae, 64

Achillea, 72

Achimenes, 76

Acland, 28

Miss, 95

Aconitum, 57

Acrocephalus, I37

Acrosticheae, IOI

Addison, 8

Adiantum, Ioo

Adoxa, 70

Aechmea, 106

Aesculus, 47, 51, 64

Aethalium, 158

Agapanthus, 96

Agaricus, I 35

Agave, 83, 127

Agrimonia, 66

Agrostideae, 86

Ailanthus, 42, 63

Silkworm, 42

"Air roots," I2 I

Ajuga, 77, I33

Alchemilla, 66

Alga, I 2

Algae, I34
Alismaceae, 86, 106

Allamanda, 74

Allspice, I Io

Almonds, 66

Aloe, I9, 126

Aloes, 84

Alopecurus, 86

Alpine Plants, 91

Alpinia, 108

Alsineae, 6I

Alsophila, IOO

Alstroemeria, 84

Althaea, 62, I32

Amarantaceae, 78

Amaryllideae, 83

Amentaceae, 82

American Aloe, 83

Plants, 73

Amomum, 108

Amorphophallus, 86, I1 5

Ampelideae, 64

Ampelopsis, I 44

Amygdalum, I 2

Anabaena, I34

Anacardiaceae, 64

Anacharis, 82, 9I

Anagallis, 74

Androsace, 74

Anemone, 56

Anemonopsis, I3I

Angraecum, I22

Anona, I09

Anonaceae, 58

Ant, I 40 
Anthemis, 72

Anthurium, I16, I23

Antirrhinum, 76

Apera, 86

Aphis, 40

Apocynaceae, 74

Apocynum, 74

Aponogeton, 86, 9I

Apple, 4I

Aquatics, 25, 90

Aquilegia, 57

Arabideae, 59

Araliaceae, 70

Araucaria, 95, I23, I3 I

Araucarinae, 87

Arbutus, 73

Archontophoenix, I I 3

Areceae, II 3

Aristolochia, 39, 108

Aristolochiaceae, 79

Armeria, 73

Aroideae, 86, I I 5

Arrowhead, 86, 9I

Arrowroot, East Indian, I08

Artemisia, 72

Artichoke, Jerusalem, 72

Artocarpeae, 8I

Artocarpus, I I 9

Arum, 86

- Lily, 97

Arundo, 99

Asafoetida, 70

Asarum, 79

Asclepiadeae, 74

Ash, Common, 5 I, 74

-, Red, 47 , Weeping, 4I

Ashmole, 6

Asparagus, 85, 99

Asperula, 7 I

Asphodel, 84

Aspidieae, IOI

Aspidistra, 85

Asplenium, IOI

Asteroideae, 7I

Atriplex, I33

A tropa, 75, I33

Atropin, 76

Aucuba, 70

Aveneae, 87
Ayliffe, I2

Azalea, 73

Azara, 43, 97

Bacterium rubescens, I35

Badhamia, I34

Baker, G., 30, IO4

一, H., I 53

Balfour, Prof., 30

Balm, 77

Balsamineae, 63

Bamboo, 87, I06, I 5I

Bambusa, 106

Bananas, 83, 103

Banksia, 95

Baptisia, 65

Barbarea, I 33

Barberry, 58

Barley, 87

Baskerville, I 88

Batatas, 75

Bateman, 25

Bauer, 2O, I54

Bauhinia, 66

Baxter, W., 22, 72, 87, I32, I50, I 72

Baxter, W. H., 22, I72

Bay rum, I IO

Bean, 65

Bear's Breech, 76

Bedstraw, 7I

Bee, I 40

Beech, 40

Beetles, I 39

Beetroot, 78

Begonia, 69, I23

Belladonna, 75

Bentinckia, I I 3

Benwell, J., 2 I, I7 I

Berberideae, 58

Berberis, 44

Bertholletia, 67

Beta, 78

Betel-nuts, I I3

Betulae, 82

Bhang, 8I

Bidder, H., I72

Bignoniaceae, 76 
Bilberry, 73

Billbergia, I06, I 20

Bindweed, 75

Bipalium, I 42

Birch, 44, 82, I4I

Bird-lime, 64

Birds, 136

Birthwort, 79

Blackberry, 67

Blackcap, I 38

Bladderwort, 76

Blue Gum, 68

Blumenbachia, 68, I33

Bobart the Elder, 5, 90, I7 I

- the Younger, 9, II, I 53, I63, I 80

Bog Bean, 9I Plants, 90

Bombax, Io9

Bonaparte, Prince C. L., 26

Bonapartea, I 28

Boragineae, 75

Borasseae, I I 4

Borrer, 25, 50

Boswell, I 50

Botanic Gardens, I

Bougainvillea, 78, 99

Bouvardia, 7I

Bowenia, I I 5

Bowstring Hemp, 83

Box Elder, 42

Boxwood, 38

Boyd, 97

Brambles, 66

Brassica, 59

Brazil-nut, 68

Bread-fruit, 8I, I I9, I 5 I

Bromeliaceae, 83, 106

Broomrape, 76

Brosimum, 8I

Broussonettia, xi, 42, 8I

Browallia, 76

Bryonia, 68

Bryony, Black, 84

Buckingham, 94

Buckland, 26

Buckthorn, 40

Buckwheat, 78

Buddleia, 75

Bulbine, I 3 I
Bulgaria, I 34

Bulimus, I 42

Bulrush, 85

Bur Reed, 85

Burbidgea, I08

Burdon-Sanderson, I 59

Burmanniaceae, 83

Bursa, I 33

Bursera, 63

Butcher's Broom, 85

Butomus, 86

Büttner, I 2

Buxus, 80

Cabbage, 59

_- walking-sticks, 59

Cabomba, IO5

Cacalia, I 28

Cacteae, 69, I 23

Cactus, 125

Calabar Bean, 65

Caladium, 86, I08, I 16

Calamai, I 5 I

Calamites, 88

Calamus, I I 4

Calathea, 108

Calceolaria, 76

Calendula, 72

Calla, 86, 97

Calophyllum, 6I

Calycanthus, 57

Camassia, 84

Camellia, 6r, 96

Camomile, 72

Campanula, I3 I

Campanulaceae, 73

Camphor, 79

Candy Tuft, 59

Canna, 83, 97

Cannabineae, 8 I

Canterbury Bell, 73

Cape Bulbs, 94

Capers, 6o

Capparideae, 60

Caprifoliaceae, 70

Capsella, 59

Caraway-seed, 70

Carex, 86

Carludovica, 85 , I I 8 
Carnarvon, Lord, 25

Carob, 96

Carpenter, G. D., I42

Carpinus, $4 \mathrm{I}$

Carrion Flower, 126

Carrot, 70

Carter, C. R., I 72

Carum, 70

Caryophylleae, 6I

Cascara Sagrada, 40

Cashew-nut, 64

Cassava, 80

Cassia, 66, I3 I

Castilloa, i 8

Castor-oil, 80

Casuarineae, 82, 95

Cat Mint, 77

Catalpa, 76

Catasetum, 122

Catha, 64

Cattleya, 122

Ceanothus, $48,64,145$

Cecropia, 8I, I I 7

Cedar, 35,48

-, N.S. Wales, 63

-_- -, West Indian, 63

Cedrela, 63

Cedrus, 19,48

Celastrineae, 64

Celosia, $7^{8}$

Centaurea, 72

Centranthus, 7I, I33

Cephalotaceae, 67

Cephalotus, i I I

Ceratonia, 66, 96, I31

Cercis, 4I, 66

Cereus, 124

Ceropegia, 74, 123, I30

Cestrum, I3 I

Chamaerops, 95

Chapman, E., 29, 1 59, 173, 196

Chara, I34

Charlemagne, 72

Charles I., 2 II., 2,4

Cheiranthus, 59

Chenopodiaceae, 78

Cherry, Common, 66

—-, Laurel, 66

Chestnut, Horse, 46
Chickweeds, 6I

Chloroxylon, 63

Chocolate, 62, I I 7

Choisya, 43

Chondrilla, I 32

Christ Church Meadow, I33, I36

Christmas Rose, 57

Chrysanthemum, 72, 96

Church, Dr., I6I

Cichorium, 72

Cinchona, $7 \mathrm{I}$

Cineraria, 96

Cinnamodendron, I I 0

Cinnamomum, 79, I Io

Circaea, 68

Cistus, 60

Citrus, 63, I3I

Cladophora, 134

Cladrastis, 47,65

Clarendon, 2

Claytonia, I 33

Clematis, $45,56, I_{44}$

Clerodendron, $\mathrm{I} 2 \mathrm{O}$

Climate, I 43

Climbing Plants, 144-I 47

Closterium, 134

Clove, 68, I 10

Clover, 65, 75

Club Moss Order, 102

Coal, 88

Cobaea, 75

Coca, 62, I 18

Cocaine, i 8

Cocculus indicus, 58

Cochineal, I24

Cochlearia, 59, I 33

Cock's-comb, 78

Coco de Mer, I 14

Cocoa, 62, I I 7

Cocoa-nut, i i4

Cocoes, i I 6

Cocoineae, I I 4

Cocos, I I 4

Coelogyne, 122

Coffee, 71, II 7

, Kentucky, 43

Colchicum, 84

Coleman, I 80

Coleus, 97

Colletia, 45,64 
Colocasia, I I6

Columbine, 57

Combretaceae, 67

Comfrey, 75

Commelinaceae, 85

Compositae, 7 I

Conferveae, I 34

Coniferae, $87,95,198$

Conifers, 4I, $4^{8}$

Conium, 69

Connaraceae, 64

Conservatory, 8

Convallaria, 84

Convolvulaceae, 75

Convolvulus, 75

Copernicia, I I 4

Copra, I I 4

Cord yline, 95, I I 5, I 23

Coreopsis, 72

Corinthian capital, 76

Cork-tree, 239

Cornaceae, 70

Cornus, 5I

Corrigiola, 78

Corydalis, 58

Coryleae, 82

Corylus, 44

Corypheae, I I 4

Costus, ros

Cotoneaster, 43, 46, 67

Cotton, 62

Cotyledon, 67

Coula, 46

Cow Tree, 8I

Cowberry, 73

Cow-itch, I IO

Cranberry, 73

Crane's-bills, 62

Crassula, 94, I 28

Crassulaceae, 67

Crataegus, 40, 48, 67

Cretan Dittany, 97

Cricket-bats, 50

Crinum, 25, 83

Crithmum, 70

Crocosmia, 94

Crocus, 83

Crotalaria, I 3 I

Croton, 80

Crowberry, 82
Crowfoots, 56

Cruciferae, 59

Crustacea, I4I

Cucumber, 68

Cucurbitaceae, 68

Cupressineae, 87

Cupressus, $44,4^{8}$

Cupuliferae, 82

Curators, I 72, I 79

Curcuma, 108

Currant, 67

Cuscuta, 75, I3 I

Custodians, I 7 I

Cycads, 43, I I 5

Cyclamen, 74

Cyclanthaceae, 85

Cymbalaria, I 32

Cynanchum, 74

Cynara, 72

Cynoglossum, 75

Cyperaceae, 86

Cyperus, 99

Cypress, $4^{8}$

Cypripedium, I 2 I

Cystopus, I 35

Cytisus, 46, 52, 65

Daffodil, 83

Dagger Plant, 128

Daisy, 7 I

Dalbergia, 65

Danby, 2, I 76

Dandelion, 72

Daphne, 44, 79

Darlingtonia, I 3 I

Dasylirion, 85 , I 28

Date Palm, 95

Datura, 76, I3 I, I33

Daubeny, I 7, 23, 33, 8I, I 52, I 55 , I65-I70, I 8I

Daubeny Cottage, I 68

Daucus, 70

Davallia, Ioo

Deadly Nightshade, 5

Deckenia, II 3

Delphinium, 57

Dendrobium, I 22

Desmodium, 65

Deutzia, 67 
Dianthus, 6 I

Diatoms, I34

Dicentra, $5^{8}$

Dicksonia, Ioo

Dictamnus, 63

Didymium, I 35

Dieffenbachia, Io8

Digitalis, 76

Dillenia, 57

Dillenius, I4, I 7

Dimorphotica, 72

Dionaea, I30, I 59

Dioon, I I 5

Dioscorea, 99

Dioscoreaceae, 84

Dioscorides, I 54

Diospyros, 47, 74

Dipladenia, 74

Dipsaceae, 7I

Dipsacus, 7 I

Dipterocarpeae, 6I

Dock, 78

Dodder, 75

Dodecatheon, 74

Dodgson, C., I60

Dogbane, 74

Dog-tooth Violet, 84

Dogwood, 5I

Doo-doo Tree, I 5 I

Doronicum, 72, I33

Dorstenia, I I9

Dracaena, 85, I I 4

Dracunculus, 86

Dragon Tree, 85 , I I 4

Drimys, 58

Drosera, 67, I 29

Druce, 29, I32, I 49

Dryandra, 95

Duckweed, 86

Dumb Cane, I 88

Duncan, J., I 5 I

Dutchman's Pipe, 79108

Ebenaceae, 74

Eccremocarpus, 76

Echeveria, 67

Echinocactus, I 24

Echinodor us, 86, 106

Eglantine, 70

Ehret, I7 I
Eichhornia, 85, IO4

Elaeagnaceae, 79

Elaeodendron, 64

Elder, 70

Elecampane, 72

Elephant's Ear, 69

- Foot, I 30

Ellis, 2, I77 I 83

Elm, 8I

Elodea, 82

Eltham Garden, I 29

Empetrum, 82

Encephalartos, I I 5, I 29

Enzymes, I62

Epacris, 73

Ephedra, 45, 87, I 47

Epidendrum, I22

Epilobium, 68

Epimedium, $5^{8}$

Epiphyllum, I25

Equisetum, 88

Eremurus, 84

Ericaceae, 73

Erigeron, I33

Eriobotrya, 45, I47

Eriocaulon, 86

Erodium, I 33

Erythrina, I 3 I

Erythronium, 84

Erythroxylon, 62, I I 8

Essence of Violets, $8_{3}$

Eucalyptus, 68, I3 I

Eucomis, 94

Eugenia, I IO

Euonymus, 46, 64

Eupatorium, 7 I

Euphorbia, I25, I33

Euphorbiaceae, 80

Euphrasia, 76

Euryale, I05

Eutoca, 75

Evelyn, 4, 6, I80

Evening Primrose, 68

Ewart, I62

Experimental Garden, I65-I70

Eyebright, 76

Fairchild, I5I

False Acacia, 44, 65

Farfugium, 97 
Farmer, Prof., I09, I6I

Fennel, 69

Ferns, 99-IOI

Ferraria, I3I

Ferula, 69

Festuceae, 87

Ficoideae, 69

Ficus, 99, I 18

Fieldfare, I 37

Fielding Herbarium, I49, I79

Fiennes, C., I27, I 52, I8I

Fig, 45, 8I, I 47

Marigold, 69

Filmy Ferns, I3I

Finance, I75

Fitzroya, 95

Flagellarieae, 85

Flax, New Zealand, 84

Flesh-eaters, I29

Flies, I 39

Flower Show, 97

Fly-catcher, I38

Forestry, School of, 3I, I98

Forget-me-not, 75

Forsythia, 74

Fowler, W. W., I37, I72

Foxglove, 76

Fragaria, 66

Frankeniaceae, 6o

Frankincense, 63

Fraxinus, 46, 74

Fritillaria, 84

Frogs, 138

Fuchsia, 68, I I 2

Fuller's Teazle, 7I

Fumariaceae, $5^{8}$

Fungi, I 35

Funtumia, I 18

Furcraea, 83, I27

Gaillardia, 72

Galactodendron, 8I

Galanthus, 83

Galium, 7I

Galls, I 39

Galphimia, 62

Gamboge, 6I

Gamopetalae, 70

Garcinia, 6I

Garnsey, I 50
Garrya, 45, I 47

Gasteria, 84, I27

Genista, 65

Gentian root, 75

Gentianeae, 75

Geraniaceae, 62

Gerarde, I

Gesneraceae, 76

Giaggiola, 83

Ginger, IO7

Ginkgo, 43

Gladiolus, 83

Glass-houses, 29

Glastonbury Thorn, 40

Glaucium, I33

Globba, I08

Gloeocapsa, I 34

Gloriosa Lily, 84, 106

Gloxinia, 76, I23

Gnetaceae, 87

Goldcrest, I 37

Gold-fish, I 35, I36

Gonium, I34

Gooseberry, 67

Goosefoot, 78

Gorse, 65

Gossypium, 62

Gotch, F., I 59

Gourds, 68

Government, I70

Grafting, 8, 52, I 25

Gramineae, 86

Granadilla, 99

Grape-vine, 8, 19, 45

Grass, Fescue, 87

- Oat, 86

Greenheart, 79

Gregory of Reggio, I 49

Grevillea, 79, 95

Grew, 9

Groom, I6 I

Ground Ivy, 77

Guaiacum, 62

Guava, 68, I I 8

Guide-books, I8 I

Gum, Sweet, 67

Gunnera, 68

Gutta-percha, 74, I I 8

Guttiferae, 6I

Gymnocladus, 43, 65 
Gymnogramma, IOI

Gymnosperms, 87

Gymnosporangium, I 35

Gynerium, 49

Gypsophila, 6I

Haemanthus, 94

Haemodoraceae, 83

Halesia, 74

Halorageae, 68

Hamamelideae, 67

Hamm, A. H., I 39, I40

Hancornia, I I 8

Harebell, 73

Hashish, 76, 8I

Haworth, 128

Hawthorn, 40

Hazel, 44, 82

Heath, Tree, 73

Hedera. See Ivy

Hedwegia, 63

Hedychium, 107, 108

Hedysarum, 5I

Heleniodeae, 72

Heliotrope, 75, 96

Helix, I 42

Hellebore, White, 84

Helleborus, 57

Hemerocallis, 84

Hemlock, 69

Hemp, 8I

- Agrimony, 7I

Henbane, 75

Henna, 68

Herbarium, ${ }_{4} 8$

Hermann, I 2

Hermodactylus, 83

Hernaria, 78

Heterotoma, I 3 I

Heuchera, 67

Hevea, 99, I I 8

Hexacentris, 99

Hibiscus, 47, 62

Hieracium, 72, I 32

Hiley, W. E., I4O, I62

Hippophaë, 79

Hippuris, 68

Hole, Dean, I 55

Holly, 64
Hollyhock, 62

Honesty, 59

Honeysuckle, 4I, 44, 70

Hooker, 28

Hop Hornbeam, 46

Hope, F. IV., I39

Hordeeae, 87

Horehound, 77

Hornbeam, 4I, 82

Horse-chestnut, 46, 5I, 64

Horse-radish, 59

- Tree, 64

Horse-tail Order, 88

Hottentot's Bread, 84, 130

Hound's-tongue, 75

House, I63

Houttuynia, 79, I3I

Howea, I 13

Hoya, 74, I 12

Humea, 97

Humulus, 8 I

Hyacinth, 84

Hydrangea, 67

Hydrocharideae, 82

Hydrolea, 106

Hydrophyllaceae, 75

Hyoscyamus, 75

Hydrosme, I 16

Hymenocallis, 94

Hypericaceae, 6I

Hyssop, 77

Iberis, 59

Ice-plant, 69

Ilex, 64

Ilicineae, 64

Illecebraceae, 78

Imbauba, I I 7

Impatiens, 63, I 33

India-rubber, 99, I 8

Indigo, I IO

—-, Wild, 65

Indigofera, 65, I 10

Insect-eaters, 129

Inula, 72

Ipomoea, 75

Irideae, 83

Iris, 83

Iron Tree, 67

Isatis, 59 
Ismene, 94

Ivy, 4I, 70, I 45

Ixia, 83

Jack-fruit, 8I

Jackson, C., I64

- - W., I 72

- W, W. H., 63, I33

Jacob's Ladder, 75

Jalap, 78

Jarrah, 68

Jasminum, 74, I I 2

Jerusalem Artichoke, 72

Judas Tree, $4 \mathrm{I}$

Juglandaceae, 82

Juncaceae, 85

Juniperinae, 87

Justicia, 77, II 2, I45

Kaempferia, Io8

Kalanchoë, 67

Kalmia, 73

Karatas, 106

Karri, 68

Kava, Io9

Kempin, Mr., I 52

Kentia, II 3

Kerria, 39, 66

Kew, I93

Kewley, 95

Kingsley, C., 169

Kirkdale, 3

Klugia, I09

Kniphofia, 84

Kochia, 78

Labdanum, 60

Labiatae, 77

Laboratory, I 55

Laburnum, 46, 52

Lachenalia, 94

Lacquer, Japanese, 64

Lactuca, 72

Lady's Slippers, I 2 I

Laelia, I22

Lagetto, I 5 I

Lamium, 77, I32

Landolphia, i 8

Lankester, Sir Ray, I42, I 57
Lapageria, 85

Lathraea, 76

Lathyrus, 65

Lauraceae, 78, 79

Laurel, Cherry, 66

—., Portugal, 66

Laurus, 43

Lavandula, 77

Lavender, 77

Lawes, J. B., I68

Lawn sand, 77

Lawson, 27, I28, I 57, I 93

Lawsonia, 68

Lectures, 155

Leea, $6_{4}$

Leek, 84

Leguminosae, 64

Lemon, 63

Lenmaceae, 86

Lens, 65

Lentibulariaceae, 76

Lentils, 65

Leonurus, I 33

Lepidium, I33

Lepidodendron, IOI

Lettuce, 72

Leucojum, 83

Library, I 52

Ligustrum, 74

Lilac, 74

Liliaceae, 84

Lily of the Valley, 85

Lime, 62

Limnocharis, Io6

Linaria, 76, I32

Lineae, 62

Linnaea, 70

Linnaeus, I 7,63

Linseed, 62

Liquid Storax, 67

Liquidambar, 67

Liriodendron, $5^{8}$

Livistona, I I 4

Loaseae, 68

Lobelia, 73

Locust Acacia, 6

Loganiaceae, 75

Lomaria, IOO

Lonicera, 44, 46, 47, 70

Lophira, 63 
Loquat, 45

Loranthaceae, 79

Lords and Ladies, 86

Loteae, 65

Lotus, Chinese, $\mathrm{IO}_{3}$

- Egyptian, $\mathrm{IO}_{4}$

Love-lies-bleeding, 78

Lunaria, 59

Lungwort, 75

Lupins, 65

Luzula, 85

Lychnis, I33

Lycopersicum, 75

Lycopodiaceae, IO2

Lygodium, IOI

Lysimachia, 74

Lythraeae, 68

Maclura, 8I

Madder, 7 I

Magdalen College, 2, I7, 8I, I36, I 55, I 63, I $77-178$

Magdalen Giant, I 36

Magnolia, 45, 58, I44

Mahogany, 63

Maidenhair Tree, 43

Maize, 86

Mallow, 6I

Malpighiaceae, 62

Malva, I 33

Malvaceae, 6I

Mamillaria, I25

Mammee Apple, 6I

Mangifera, 64

Mango, 64

Mangold Wurzel, 78

Mangosteen, 6I

Mangrove, 67

Manihot, 80

Manna, 46

- Ash, 46

Mantisia, 108

Maple, 47, 64

- Japanese, 5 I

Maranta, 83, 108

Marattia, IOO

Mare's-tails, 68

Marjoram, Sweet, 77

Marrubium, 77

Marsilea, I3 I
Marvel of Peru, 78

Maryophyllum, IO3

Masdevallia, I22

Masters, M. T., I 50

Mastic, 64

Mathiola, I 33

Meadow Sweet, 59

Medici, Cosmo de, I80

Medicinal Herbs, 89

Meliaceae, 63

Melon, 69

Meni, 63

Menispermum, 4I, $5^{8}$

Mentha, 77

Menyanthes, 9I

Mesembryanthemum, 69, 128

Mignonette, 60

Milium, 86

Milkwort, 60

Millet, 86

Millington, 9

Mimoseae, 66

Mimulus, 76

Mirabilis, 78

Missel-thrush, I37

Mistletoe, 79, I 33

Mite, I 4 I

Mohle Flowers, I I 2

Monkeys, 26, I 35

Monkey-flower, 76

Monkshood, 57

Monochlamydeae, 78

Monocotyledons, 82

Monodora, 58

Montbretia, 83

Moraceae, 8I

Moraea, 94

Moringa, $6_{4}$

Moringeae, 64

Morison, 4, I 55, I 80

Morus, 42

Moschosma, 97

Mougeotia, I34

Mucuna, I Io

Mulberry, 42, 8I

- Paper, 42

Mullein, 76

Musa, 83, IO3, I3 I

Muscari, 84

Museum, 28, I 5I 
Musk, 76

Musschia, I3I

Mustard, 59

Mustard-tree, 74

Mutisieae, 72

Mycorhiza, 73

Myosotis, 75

Myricaceae, 82

Myristiceae, 79

Myrmecodia, I09

Myrobalans, 67

Myrrh, 63

Myrtaceae, 67

Myrtle, 67, 82

Naiadaceae, 86

Nandina, I 3 I

Nartheca, 69

Nasturtium, 63

Nectandra, 79

Nectria, I 35

Neem, 63

Negundo, 42

Nelumbium, IO3

Nematus, I 39

Nemophila, 75

Nepenthaceae, 79

Nepenthes, Io8

Nepeta, 77

Nephrodium, IOI

Nephthytis, I I 6

Nerium, 74

Nettle, 8I

- Dead, 77

New Zealand Flax, 84 , I 5 I

Newbould, W., I 49

Nicotiana, I9, 76

Nightshade, Deadly, 75

Nopal, I 24

Norfolk Island Pine, 95

Nostoc, I 34

Nutmeg, 79

Nux vomica, 75

Nyctagineae, 78

Nymphaea, IO4, I3I

Nymphaeaceae, $5^{8}$

Oak, African, 63

—, Evergreen, 38
Oak, Holm, 38

-, Turkey, 46

Odontoglossum, I23

Oenothera, 68

Officers, I 7 I

Olacineae, 64

Old Man Cactus, I 24, I30

Oleaceae, 74

Oleander, 74

Olearia, 46

Olive, 74

Onagraceae, 68

Oncidium, I 23

Onion, 83

Onobrychis, 65

Opium, $5^{8}$

Opuntia, I 24

Orange, 63, 94

—_, Osage, 8I

- , Prince of, 180

Orchideae, 25, 83, I2O-I 23

Orders, I 73

Oriental Plane, 279

Origanum, 97

Ornithogalum, 84, 94

Orobanchaceae, 76

Orris-root, 83

Ortgiesia, 107

Osage Orange, 8I

Oscillatoria, I 34

Osmunda, 88, IOI

Ostrya, 46

Ouvirandra, 86, Io6

Owl, I37

Owstrowskia, 73

Oxalideae, 62

Oxalis, I08, I 33

Oxford Ragwort, 71, I32

Oxyria, 79

Paeonia, 57

Palaquium, 74, 99

Palisota, 85

Paliurus, vi, I9, 39, 64, I44

Palmeae, 85

Palms, I I 3-I I 4

-, Date, I I 3

-, Palmyra, I I 4

- -, Sago, I I 5

- W Wax, I I 4 
Pampas Grass, 48

Panama hats, i I 8

Pancratium, 83

Pandaneae, 85

Pandanus, II 4

Pandorina, I34

Panicum, 86

Pansy, 60

Papaveraceae, $5^{8}$

Papaw, 68

Paper Mulberry, 42

Papyrus, 86, $\mathrm{IO}_{2}$

Paralysis, 6

Parks, 27, 237

Parnassia, 67

Parrottia, 5I, 63, I46

Parsley, 69

Parson's Pleasure, I 38

Passiflora, 68, 99

Passifloreae, 68

Pastinaca, 69

Patchouli, 77, I IO

Paulownia, 76

Pea, 65

Pear, 4 I

Pediastrum, I34

Peepul, I 8

Pennyroyal, 77

Pentstemon, 76

Peperomia, 79, I09

Pepper, 79, I09

- Guinea, I9

Peppermint, 77

Pereskia, I 25

Periwinkle, 74

Persimmon, 47,74

Peruvian Lily, 84

Petunia, 76

Peziza, I35

Phajus, I23

Phaseolus, 65

Philadelphus, 67

Phillips, 27

Philougria, I 4 I

Phleum, 86, I32

Phlomis, 77

Phlox, 75

Phoenix, 95, I I 3

Phormium, 84

Photinia, 45
Phyllocactus, 125

Phyllotaxis, I62

Physostigma, 65

Phy.tolaccaceae, 78

Phytophthora, I 35

Pilocereus, I24

Pimenta, I09

Pine-A pple, 83, 106

Pinetum, 47

Pinguicula, 76

Pink, 6I

Pinoidea, 87

Piper, I09

Piperaceae, 79

Pipewort, 86

Pistachio nuts, 64

Pistacia, 64

Pistia, 86, I05

Pisum, 65

Pitcairnia, I06

Pitcher Plants, 79, 107

Pittosporeae, 60

Plantagineae, 77

Plantain, 77

Plantanaceae, 82

Platanus, 6

Platycerium, roo

Plum, 66

—_, Sapodilla, 74

Plumbagineae, 73

Plumbago, 73

Podocarpus, I 3 I

Podophyllin, $5^{8}$

Podophyllum, $5^{8}$

Podostemaceae, 78

Pogostemon, I IO

Poinsettia, 80

Poison Ivy, 53, 64

Pokeweed, 78

Polemoniaceae, 75

Polygaleae, 60

Polygonaceae, 78

Polygonatum, 84

Polypodium, IOI, I 5I

Pomeae, 67

Pomegranate, 5I, 67

Pond weed, 86

Pontederiaceae, 85, I3 I

Poor Man's Weather Glass, 74

Poplar, 5I, I33 
Populus, 5 I

Portulaceae, 6I

Potamogeton, 86

Potato, 75

-, Sweet, 75

Potentilla, 66, I 33

Poterium, 66

Pothos, I08

Prickly Pear, I 24

Primula, 6, 74

Primulaceac, 74

Prince's Feather, 78

Prints, I 86

Pritchardia, I I 4

Privet, 74

Professor's House, I63

Professors, I7I

Proteaceae, 79, 95

Prunus, 39, 47

Psidium, I 8

Ptelea, 4I

Pteris, IOO

Pterocarpus, 65

Pulmonaria, 75

Pumpkin, 69

Punica, 67

Purslane, 6I

Puschkinia, 84

Pyrus, 39, 40, 41, 6

japonica, 51, 146

Pythium, I35

Quassia, 63

Quercus, 38, 47

Quesnelia, I07

Quinine, 7 I

Radish, 59

Ramondia, 76

Ranunculaceae, 56

Raphanus, 59

Raphiolepis, 98

Raspberry, 67

Razor-strop, 128

Redstart, Black, I37

Redwing, I37

Reed Warbler, I37

Reeds, 9 I

Rehmannia, I3I

Reinwardtia, I I 2

Reseda, I33
Resedaceae, 60

Restiaceae, 86

Rhamnaceae, 64

Rhamnus, 40

Rheum, 78

Rhipsalis, I 26

Rhizophoreae, 68

Rhododendron, 73, I3I

Rhodostachys, IO7

Rhubarb, I9, 78

Rhus, 42, 64

Ribes, 39, 67

Rice-paper, 70

Richardia, 86, 97

Richards, F. T., 172

Ricinus, 80

Robinia, 44, 65

Robinson, 93

Rohdea, 85

Rolleston, G., I 56

Romanes, G., I69

Rosa, 44, 66, 89, I 47

Rosaceae, 66

Rosemary, 77

Rosewood, 65

Royal Fern, 88

Rubber, I 8

Rubiaceae, 7 I

Rubus, 43, 67, I 45- I 48

Rudbeckia, 72

Rue, 63

Ruellia, 77

Rules, I 73

Rumex, 79, I 32

Ruscus, 85

Rush, 85

- Flowering, 86

Ruskin, I 55

Rutaceae, 63

Sabal, II 4

Sacred Bo Tree, I I9

Sadler's balloon, 20

Sage, 77

Sagittaria, 86, I 3 I

Sainfoin, 65

St. John's College, I 70

St. John's Wort, 6I

Salicetum, 49

Salicine, 5 I 
Salicineae, 82

Salicornia, 78

Salix, 50

Salpiglossis, 76

Salsola, 78

Saltwort, 78

Salvadoraceae, 74

Salvia, 89, I I2

Salvinia, Io6

Samphire, 78

Samydaceae, 68

Sandys, I3

Santalaceae, 8o

Sap Green, 40

Sapindaceae, 63

Sapodilla Plum, 74

Saponaria, 6I

Sapotaceae, 74

Saprolegnia, I35

Sarracenia, I30

Sarraceniaceae, $5^{8}$

Sarsaparilla, 85

Satin wood, 63

Saunders, $W^{r}$., I 28

Saw-flies, I 39

Saxifrageae, 67

Scarborough Lily, 83

Scenedesmus, I 34

Schizanthus, 76

Schlich, Sir W., I 98

Schultes, 22

Scilla, 84

Scitamineae, 83, IO7-Io8

Scleranthus, 78

Screw Pine, 85, I I 4

Scrophularineae, 76

Scurvy Grass, 59

Sea Blite, 78

Buckthorn, 79

Pink, 73

Seaforthia, I I 3

Sedge, 86

Sedum, 67, I 33

Selaginellaceae, IOI

Sempervivum, 67

Senecio, 7I, I28, I32

Sensitive Plant, 6, I9, 66, I I6

Sequoia, 35

Service Tree, 40, 46

Sexuality:of plants, 9
Shadwell, C., I 72

Sharrock, R., 8

Shaw, I 49

Shelley, I 7

Shepherd's Purse, 59

Sherard, I3, 92, I 49, I 53, I 73

Sherardia, 7 I

Sibthorp, Humphrey, 20

- - John, 20, 72, I49, I 53, I64

Sibthorpia, 20, 76, 90

Silk rubber, i 8

Silkworm, Mulberry, 42

Silky Oak, 96

Silver Tree, 96

Siphonia, 80

Sisymbrieae, 59

Sisyrinchium, 83

Sloane, I 5 I

Slug, I 42

Smilax, 39, 85, I 45

Snail, I 42

Snake's Heads, 84

Snapdragon, 76

Snowdrop, 83

- Tree, 74

Snowflake, 83

Soapwort, 6I

Solanaceae, 75

Solanum, 75, 99

Soldanella, 74

Solomon's Seal, 84

Sophora, 38, 65

Sorbière, I I

Sorrel, 79

Sour Sop, 109

Sparganium, 85

Spathiphyllum, I 6

Spearmint, 77

Speedwell, 76

Spergula, 6I

Sphaeotheca, I.35

Spiderwort Order, 85

Spinach, 78

Spinacia, 78

Spiraea, 45, 46, 66

Spirogyra, I 34

Spondias, I3I

Spurge, 80

Stachys, 77

Stag's-horn Fern, Ioo 
Stangeria, I 5

Stanhopea, 123

Stapelia, 74, I 26

Staphylea, 4I, 64

Star of Bethlehem, 84

Statice, 73

Stellaria, 6r

Stenocarpus, 96

Stereum, I35

Stock, 59

Stonecrop, 67

Stratiotes, 83

Strawberry, 66

Streptocarpus, 76, 99, I3I

Strychnine, 75

Strychnos, 75

Sturch, I62

Styraceae, 74

Suaeda, 78

Succulents, I23, I93

Sugar-cane, 106

Sumach, 64

Sundew, 67, I29

Sunflower, 72

Susum, 85

Sweet Gum, 63

- Marjoram, 77 Potato, 75

Swietenia, 63

Sycamore, 5

Symbiosis, I09, I I 7

Symphytum, 75

Syringa, 74

Taccaceae, 84

Tagetes, 72

Tamariaceae, 6I

Tamarind, 79

Tamarindus, 66, I I

Tamarix, 5I, I 46

Tamus, 84

Tanacetum, 72

Tansy, 72

Tapioca, 80

Taraxacum, 72

Tatham, E., I 55

Taxodinae, 87

Taxodium, 39

Taxoideae, 87

Tea, 6 I
Teak, 77

Teazle, Fuller's, 7 I

Tecoma, 76, I 31

Tectona, 77

Ternstroemiaceae, 6I

Testudinaria, 84, I30

Thalictrum, 56

Theobroma, 62, I I I

Thesium, 80

Thistle, 72

Thoresby, I 5 I

Thorn, 40, 48 Apple, 75

Thrift, 73

Thrinax, I 44

Thrush, 136

Thunbergia, 77, II 7

Thyme, 77

Thymelaeaceae, 79

Tigridia, 83

Tiliaceae, 62

Tillandsia, I07

Toadflax, 76

- - Bastard, 80

Tobacco, 76

Todea, IOO

Tomato, 75

Tradescant, I, 9I, I5I, I7 I

Tradescantia, 85

Trees, 35

Trichormanes, IOO

Trichoniscus, I4 I

Tricycla, 78

Trifolium, 65

Trionfetti, I2

Tropaeolum, 63

Trowe, I3

Trumpet Tree, II 7

Tulip, 84, I 33

- Tree, 58

Turmeric, 108

Turneraceae, 67

Tussilago, 72

Tutsan, 6I

Typhaceae, 85

Uffenbach, II

Ulmeae, 8I 
Umbelliferae, 69

Uredineae, I35

Urostigma, I I 8

Urticaceae, 9 I

Urticularia, 76

Ustilago, I 35

Vaccinium, 73

Valerianeae, 7 I

Valerianella, I 32

Vallisneria, 82

Vallota, 83, 96

Vanda, I23

Vanilla, I2 I

Variegated Plants, 5

Vaucheria, I34

Venus' Fly-Trap, I 30, I 59

Veratrum, 84

Verbascum, 76

Verbenaceae, 77

Veronica, 76

Vervain, 77

Vestia, I3I

Viburnum, 47, I 45

Vice-Chancellor, 2

Vicia, 65

Victoria Lily, 98

Villarsia, I 3 I

Vinca, 74

Vine, $8,19,45,64$

Vines, Professor, 30, I07, I 59, I6 I

Violaceae, 60

Viscum, 79

Visitors, 180

Vitis, 45

Vitus, 99

Wallflower, 59

Walnut, 82

-, Black, 5 I

Wasp, I 40

Water Hyacinth, $\mathrm{IO}_{4}$

—- Lily, 9I, $\mathrm{IO}_{4}$

Plantain Order, 86

- Soldier, 82

Wratsonia, 83

Wattle, 96

Wreeds, I32
Welling tonia, 35

Welwitschia, 87

-Wheat, 87

Whitethroat, I 38

Williams, 22, 94, I29, I 53

Willow, 49, 5I, 82 Herb, 68

Willow-wren, I 38

Winter's bark, 58

Wistaria, 4I, 65, I47

Witch Hazel, 67

Witch's Broom, I4I

Woad, 59

Wood, 2 Oil, 6I

Woodpecker, I 37

Woodruff, 7 I

Wood-sorrel, 62

Worms, I 42

Wormwood, 72

Wound wort, 77

Wourali, 75

Vurmbea, 94

Wyatt, J., I63

Ximenia, 64

Xylaria, I35

Xyrideae, 85 .

Yams, 84, 99, I30

Yarrow, 72

Yellow Wood, 47

Yew, 9, 42

York, Duke of, I $80^{\circ}$

Yucca, 85, I28, I3 I

Yulan, 45

Yule, C., I 59

Zamia, I I 5

Zea, 86

Zelkova, 204

Zephyranthes, 94

Zingiber, 83, 108

Zinnia, 72

Zizyphus, 64

Zoology, I 35, I 78

Zygnema, I57

Zygophylleae, 62 


\section{N D E X I I}

\section{THE COLLEGE GARDENS AND THE PARKS}

The largest specimen of a tree is indicated by the page number being printed in clarendon type.

ABIEs grandis, 240

- nordmanniana, 235

Acacia, False. See Robinia

Acer monspessulanum, 203

— platanoides, 204

- saccharinum, $2 \mathrm{O}_{4}$

- tartarica, 240

Addison's Walk, 22 I

Aesculus carneum, 203, 22 I

Ailanthus, 203, 205, 229, 232, 235,236

Alder, 203, 205, 233

---, Cut-leaved, 226, 240

All Souls College, 225

Almond, 205

Alnus, 203, 205

Amelanchier ovata, 229

Aphis, 239, 240

Apple, 228, 229, 232, 235, 236, 248

Arabis, 222

Araucaria imbricata, 235, 242

Arbor vitae, 248

Ash, 203, 222, 233

- Mountain, 223, 225

- Weeping, 233, 235

Aster, 222

Balliol College, 229

Bateman, J., 238

Baxter, W. H., 238

Beech, 2O3, 22 I, 233, 245, 259

-, Copper, 223, 232
Beech, Cut-leaved, 222, 242

—., Purple, 234, 236, $24^{8}$

- Weeping, 239, 248

Betula papyrifera, 243

Bidder, Rev. H., 230

Birch, 2O4, 22O, 223, 229, 235. 248

-_---, Paper, 243

Bodleian Library, 225

Box, 206, 232

Brasenose College, 225, 226

Broussonettia papyrifera, 234

Brown, "Capability," 230

Buckthorn, Sea, 239

Carter, Rev. C. R., 222

Castanea. See Chestnut, Spanish

Catalpa, 206, 223, 228, 229

Ceanothus veitchianus, 229

Cedar, Atlantic, 242

- - Deodar, 242

- of Lebanon, 224, 23I, 233 ,

245,248

Cerasus padus, 220

- serrulata, 229 virginica, 229

Cercis, 135, 248

Chamaecyparis nootkaensis, 242

Charles II., 237

Cherry, Bird, 220

—-, Double, 206

___. Laurel, 235 
Chestnut, Horse, 207, 209, $22 \mathrm{I}$, 223, 226, 23I, 232, $24^{8}$ - Double Horse, 243

--, Spanish, 242, 245

Christ Church, 203-207

Cinclidotus, 222

Cladrastis, 243

Cork Oak, 239

Cormorant, 247

Cornus, 240

Cothill, 25 I

Cotoneaster frigida, 229

- montana, 239

Crab, 220

Crataegus coccinea, 204

— crus galli, 234

- douglasii, 204

- - sp., 229, 243

Crayfish, 22 I

Cypress, 209

Cytisus quercifolia, 243

Daubeny, 238, 242

Davidia involucrata, 229

Dimorphanthus mandshuricus, 231

Dogwood, 240

Dokks, 222

Elder, 247

Elm, 203, 205, 209, 2 I2, 2 I 5, 223, 23I, 235, 240, 24I, 245

- Huntingdon, 206

- Jo. Pullen's, 249

-, Weeping, 205, 240

- Wych, 218

Epiphytic Plants, 258

Euonymus latifolius, 229

Eurhynchium, 222

Exeter College, 225

Fagus. See Beech

Fiennes, Celia, 220, 223

Fig, 206, 209. 226, $23 \mathrm{I}$

Fletcher, C. R. L., 245,246

Fowler, W. W., 227

Fraxinus lentiscifolia, 205

- monophylla, 203

Fritillary, 222
Garrya, 235

Ginkgo, 234

Gleditschia, 234

Green, J. R., 22 I

Hazel, Turkish, 239

Heber, 226

Hickory, 209

Hieracium, 259

High Street, 246

Holly, 235, 236, $24^{8}$

Hopkins, T., 22 I, 238

Hornbeam, 205, 22 I, 229, 233

Horse-chestnut, 207, 209, $22 \mathrm{I}$, 223, 226, 23I, 232, 248

— D Double, 243

- , Red, 203, $22 \mathrm{I}$

Ilex. See Oak, Evergreen

Ivy, 210, 225

Jackson, T. G., 247

Johnson's Piece, $25 \mathrm{I}$

Judas Tree, 235, 248

Juniper, 231

Kennicott, 226

Laburnum, 23I, 234

Larix microcarpa, 242

Laurel, Cherry, 235

Lawson's Cypress, 222, 236

Iibocedrus decurrens, 235

Lilac, 248

Lime, 203, 208, 22 I, 223, 228, 23I, $234,24 \mathrm{I}$

Weeping, 234, 248

Lincoln College, 227

Liriodendron. See Tulip Tree.

Magdalen College, 209

Magnolia acuminata, 234

- soulangeana, 229

Maple, 2O3, 22 I

- Norway, 204

Maundrell, 226

Medlar, 235 
Merton College, 207

Mesopotamia, 237, 243

- Willows, 253

Mistletoe, I 33

Morus, 206, 209

Mountain Ash, 223, 225, 256

Mountain Ash, Pendulous, 239

Mulberry, 206, 207, 208, 209, $219,229,231,233,245$, 247,248

- Paper, 234

Napier, 222

Negundo, 203

New College, 223

Oak, 205, 214, 221, 222, 236

—, Cork, 239

- Evergreen, 209, 23I, 233, $234,235,248$

—, Lucombe, 235, 236, 239

- sp., 239

, Turkey, 205, 235, 248

Oxford Ragwort, 236

Parks, 237

Pear, 206, 209, 226, 228, 23I, 236, 247

Pembroke College, 207

Pine, Mountain, 239, 242

- Weymouth, 239

Pink, Cheddar, 236

Pinsapo, 222

Pinus cembra, 242

- excelsa, 204, 209, 235

- sylvestris, 23I, 235, 236

Plane, 204, 205, 220, $22 \mathrm{I}, 228$, 229,232

- Oriental, 204, 206

Planera. See Zelkova.

Poa, 222

Pococke, Edward, 206

Polygonum baldschuanum, 23 I

Poplar, 244, 248

- Lombardy, 221, 240

-, White, 233

Populus abele acerifolia, 240

sp., 203

Pugin, 224
Pyrus intermedia, 203

- pinnatifida, 204

- riviolaris, 239

Queen's College, 209

Quercus cerris, 205, 235, $24^{8}$

- spectabilis, 220

Raper, R. W., 243

Red-wood, 234, 235

Rhododendron, 204

Robinia, 206, 209, 21 2, 219,225, $233,234,236,247,248$ hispida inermis, 234

Rose, Wild, 254

Routh, Dr., 2 I9, 237

Rowan, 223, 225, 256

Ruskin Reserve, $25 \mathrm{I}$

St. John's College, 230

Salix fragilis, 204

Scotch Fir, 23I, 235, 236

Senecio squalidus, 236

Sequoia gigantea, 204, 222, 236

sempervirens, 234, 235

Sewell, Warden, 224

Shenstone, 245

Shipley, 233

Shotover Hill, 25 I

Somerville, Prof., 239

Sophora, 243

Swans, 221

Sycamore, 208, 225, 242, 247

-, Variegated, 22 I

Symons, Warden, $24 \mathrm{I}$

Tamarack, 242

Taxodium distichum, 240

Thorn, 204, 205, 229, 231, 236

- sp., 243

Thuja gigantea, 204

pygmaea, $23 \mathrm{I}$

Thujopsis alba, 243

- argentea, 24I

- aurea, 240

borealis, 242

heterophylla, 240

Tilia petiolaris pendula, $234,24 \mathrm{O}$, 248 
Tournay, Warden, 235

Trill Mill Stream, 205

Trinity College, 228

Tulip Tree, 209, 223, 235, 248

Ulmus. See Eln.

Ulmus glabra, 205

- glabra pendula, 240 montana, 218 montana nana, 239 montana pendula, 204,

205

University College, 209 Park, 237

Vine, 227, 230

Virginia Creeper, 207
Wadham College, 233

Walnut, 206, 207, 209, 2 I3, 232, 236

Weigela rosea, 204

Wellingtonia, 204, 222

Willow, 205, 233, 243

- Poplar, 204

Willow-gardens, 253

Wills, Warden, 233

Wilson, Rev. H. A., 2 I9

Wistaria, 228, 229, 23I

Worcester College, 232

Yew, 206, 209, 228, 23I, 248

- Table, 242

-, Yellow-berried, 242

Zelkova, 203, 204, 240 



\section{Date Due}

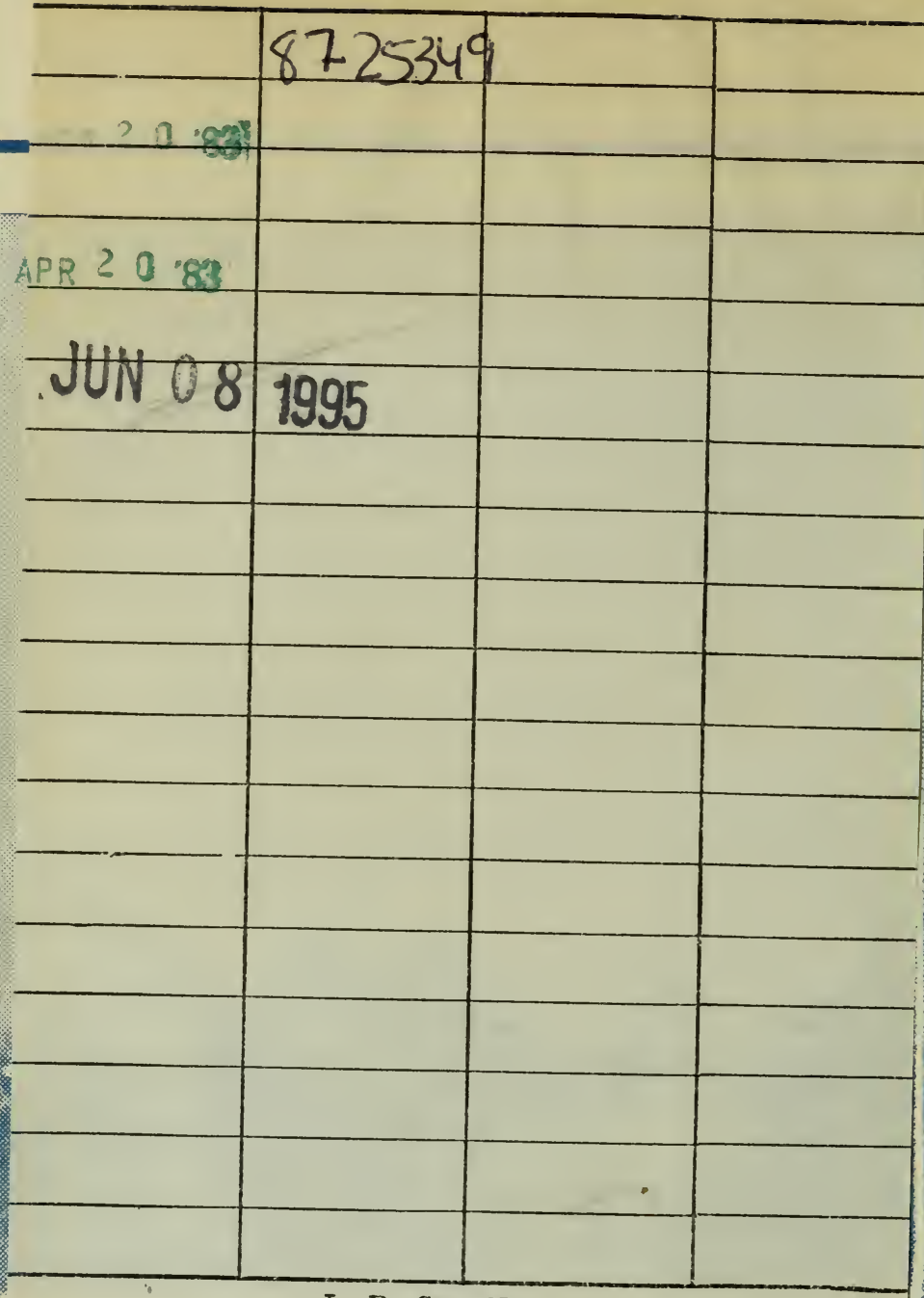

L. B. Cat. No. II 37

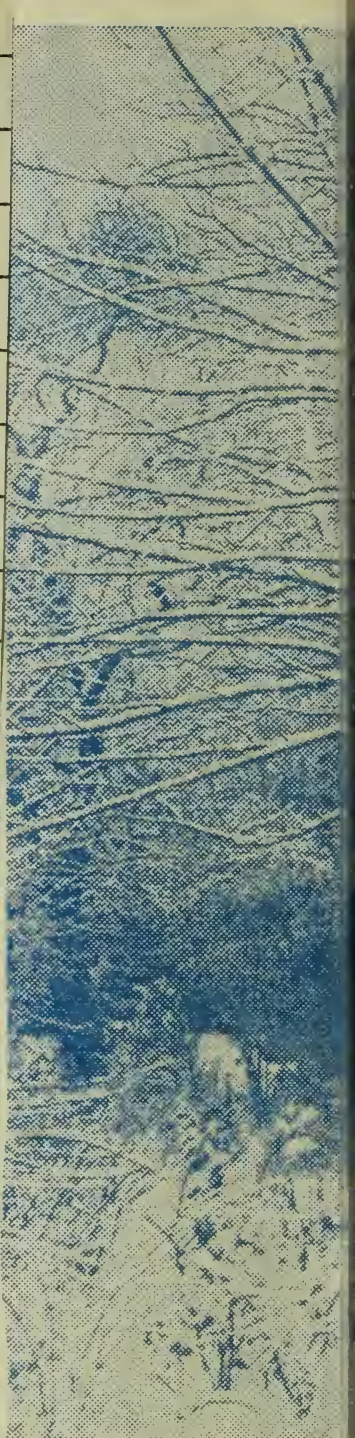

The Obshrvatory Plantation, University Park 


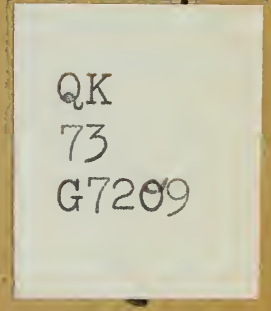


